\title{
A Foundation for Collaboration: An Analysis of Robert Schumann's Dichterliebe, Op. 48
}

\author{
Kailang Zhan \\ West Virginia University, kazhan@mix.wvu.edu
}

Follow this and additional works at: https://researchrepository.wvu.edu/etd

Part of the Musicology Commons, Music Performance Commons, Music Practice Commons, Music Theory Commons, and the Other Music Commons

\section{Recommended Citation}

Zhan, Kailang, "A Foundation for Collaboration: An Analysis of Robert Schumann's Dichterliebe, Op. 48" (2021). Graduate Theses, Dissertations, and Problem Reports. 8107.

https://researchrepository.wvu.edu/etd/8107

This Dissertation is protected by copyright and/or related rights. It has been brought to you by the The Research Repository @ WVU with permission from the rights-holder(s). You are free to use this Dissertation in any way that is permitted by the copyright and related rights legislation that applies to your use. For other uses you must obtain permission from the rights-holder(s) directly, unless additional rights are indicated by a Creative Commons license in the record and/ or on the work itself. This Dissertation has been accepted for inclusion in WVU Graduate Theses, Dissertations, and Problem Reports collection by an authorized administrator of The Research Repository @ WVU.

For more information, please contact researchrepository@mail.wvu.edu. 
Graduate Theses, Dissertations, and Problem Reports

2021

\section{A Foundation for Collaboration: An Analysis of Robert Schumann's Dichterliebe, Op. 48}

Kailang Zhan

Follow this and additional works at: https://researchrepository.wvu.edu/etd

Part of the Musicology Commons, Music Performance Commons, Music Practice Commons, Music Theory Commons, and the Other Music Commons 
A Foundation for Collaboration: An Analysis of Robert Schumann's Dichterliebe, Op. 48

\author{
Kailang Zhan
}

A Doctoral Research Project submitted to

the College of Creative Arts

at West Virginia University

In partial fulfillment of the requirements for the degree of

Doctor of Musical Arts in

Collaborative Piano

Lucy Mauro, D.M.A., Chair and Research Advisor

James Miltenberger, D.M.A.

Mitchell Arnold, D.M.A.

General Hambrick, M.F.A.

School of Music

Morgantown, West Virginia

2021

Keywords: Robert Schumann, Dichterliebe, Heinrich Heine, Lyrisches Intermezzo, collaborative piano, song cycle analysis

Copyright 2021 Kailang Zhan 


\begin{abstract}
A Foundation for Collaboration: An Analysis of Robert Schumann's Dichterliebe, Op. 48 Kailang Zhan

This paper provides an analysis of Robert Schumann's Dichterliebe offering historical information and insights into each of the sixteen songs. The analysis includes the English translation of the texts and discussion of the form of each song as well as highlights of the special moments of harmonic, rhythmic, and melodic structure in relation to Schumann's setting of each poem. The analysis provides a foundation for collaborative skills for the singer and pianist for the study and performance of Dichterliebe. In addition, the paper includes brief biographies of Robert Schumann and Heinrich Heine and background information on the poetry and the development of the cycle. Two appendices provide information on historic and current recordings of Dichterliebe and the available editions.
\end{abstract}




\section{ACKNOWLEDGEMENTS}

This paper is dedicated to my grandparents and my parents Guozhong Zhan and Chunjie Xia. Their unselfish love and support are the greatest of all gifts, which have helped me to achieve my goals. My gratitude also goes to my dear professor Dr. Lucy Mauro, who taught me for six years. I truly appreciate her patient and passionate teaching and help in guiding me to be the professor I want to become. Moreover, I thank my entire committee, Dr. James Miltenberger, Dr. Mitchell Arnold and Professor General Hambrick, for spending a great amount of time attending my hearings, recitals, and Young Artist Competition, and for their wisdom and advice. Last but not least, my thanks go to West Virginia University and the Colleges of Creative Arts for helping me to achieve my dreams. 


\section{TABLE OF CONTENTS}

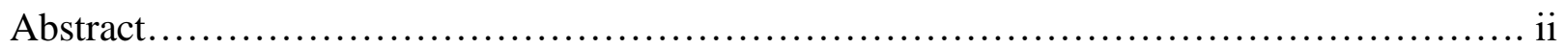

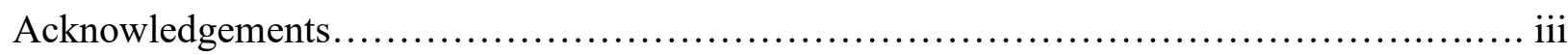

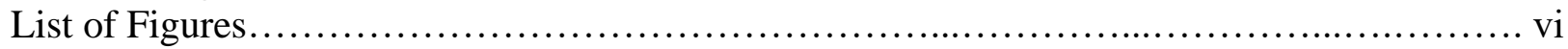

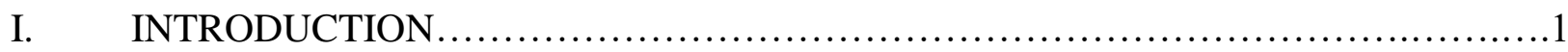

II. BRIEF BIOGRAPHY OF ROBERT SCHUMANN $(1810-1856) \ldots \ldots \ldots \ldots \ldots \ldots \ldots \ldots . . \ldots$

III. BRIEF BIOGRAPHY OF HEINRICH HEINE (1797-1856).........................13

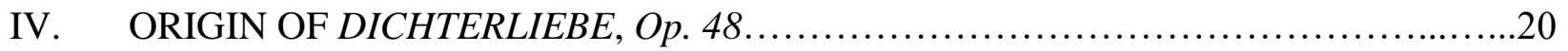

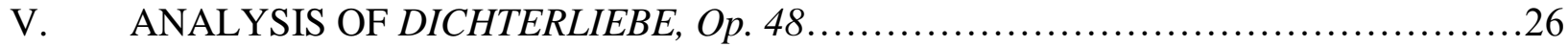

1. "Im wunderschönen Monat Mai" .........................................26

2. “Aus meinen Tränen sprießen" .............................................. 31

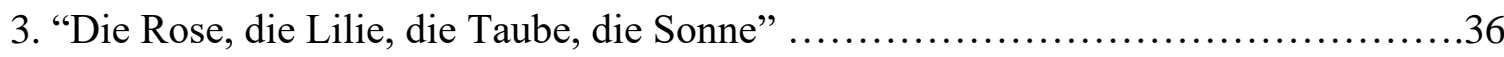

4. "Wenn ich in deine Augen she" ............................................ 41

5. "Ich will meine Seele tauchen" ..........................................46

6. "Im Rhein, im heiligen Strome" ............................................ 51

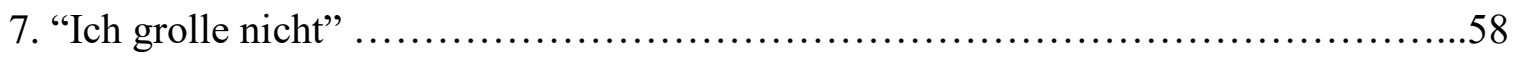

8. "Und wüßten's die Blumen, die kleinen" .....................................64

9. "Das ist ein Flöten und Geigen" ................................................ 71

10. "Hör' ich das Liedchen klingen” . ........................................ 78

11. "Ein Jüngling liebt ein Mädchen" ....................................... 84

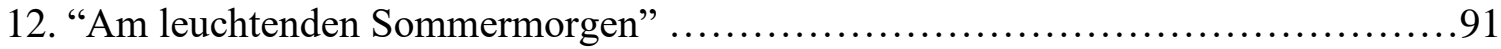

13. "Ich hab' im Traum geweinet" ............................................ 98

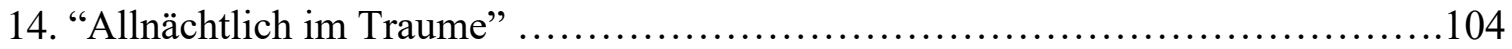

15. "Aus alten Märchen winkt es" ........................................... 110

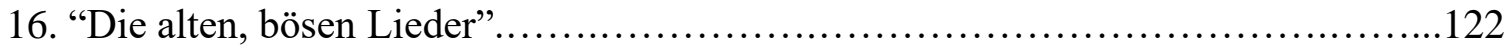


VI. CONCLUSION

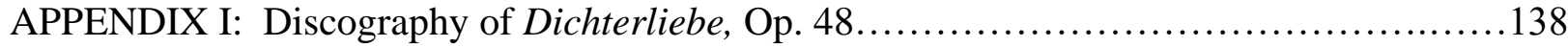

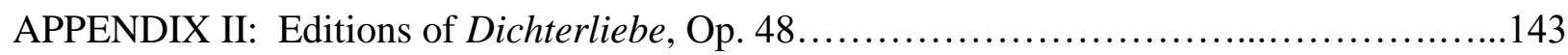

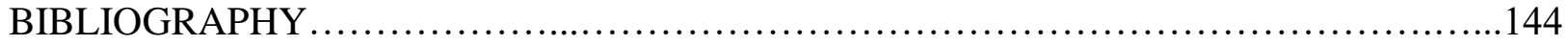




\section{LIST OF FIGURES}

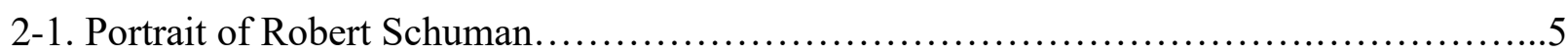

3-1. Lithograph of Heinrich Heine.................................................... 13

4-1. Table of Poems in Lyrisches Intermezzo and Dichterliebe ................................22

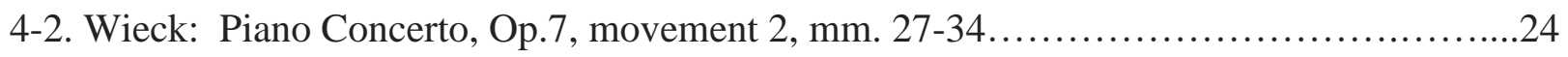

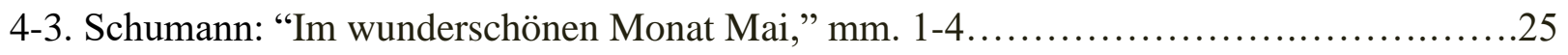

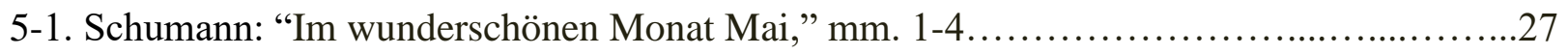

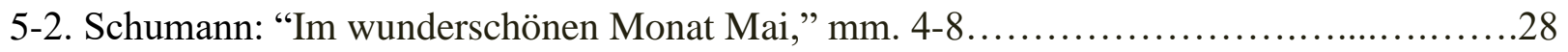

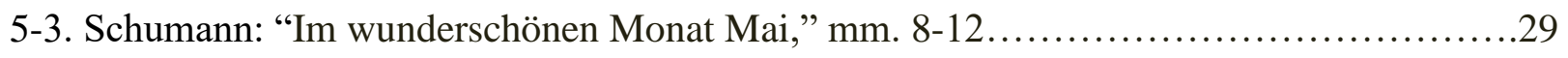

5-4. Schumann: "Im wunderschönen Monat Mai," mm. 22-26 .................................. 30

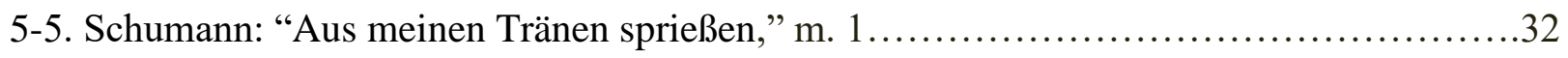

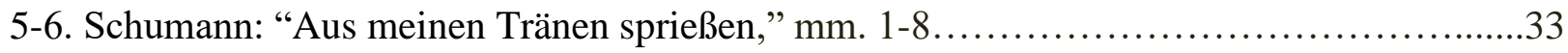

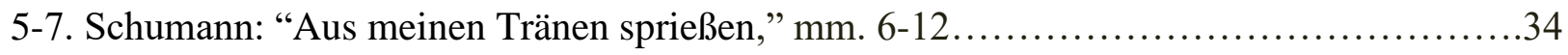

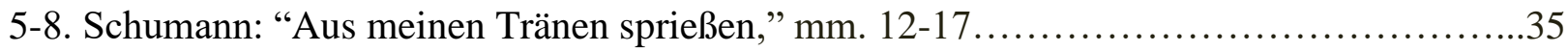

5-9. Schumann: "Die Rose, die Lilie, die Taube, die Sonne," mm. 1-4 .........................37

5-10. Schumann: "Die Rose, die Lilie, die Taube, die Sonne," mm. 4-8 ........................38

5-11. Schumann: "Die Rose, die Lilie, die Taube, die Sonne," mm. 8-11 .......................39

5-12. Schumann: "Die Rose, die Lilie, die Taube, die Sonne," mm. 16-17 .....................39

5-13. Schumann: "Die Rose, die Lilie, die Taube, die Sonne," mm. 17-22 .....................40

5-14. Schumann: "Wenn ich in deine Augen seh'," mm. 1-3 ................................42

5-15. Schumann: "Wenn ich in deine Augen seh'," mm. 4-7 ..................................42

5-16. Schumann: "Wenn ich in deine Augen seh'," mm. 8-12 .............................43

5-17. Schumann: "Wenn ich in deine Augen seh'," mm. 12-14 ................................44

5-18. Schumann: "Wenn ich in deine Augen seh'," mm. 16-21 ..............................45

5-19. Schumann: "Ich will meine Seele tauchen," m. 1 .....................................47

5-20. Schumann: "Ich will meine Seele tauchen," m. 6-8 ...................................48

5-21. Schumann: "Ich will meine Seele tauchen," m. 13-16 ................................48 
5-22. Schumann: "Ich will meine Seele tauchen," m. 16-22 ................................49

5-23. Schumann: "Im Rhein, im heiligen Strome," m. 1-7 ......................................52

5-24. Schumann: "Im Rhein, im heiligen Strome," m. 12-21 ..................................53

5-25. Schumann: "Im Rhein, im heiligen Strome," m. 23-35 ...................................54

5-26. Schumann: "Im Rhein, im heiligen Strome," m. 34-44 ........................................55

5-27. Schumann: "Im Rhein, im heiligen Strome," m. 40-58 _..................................56

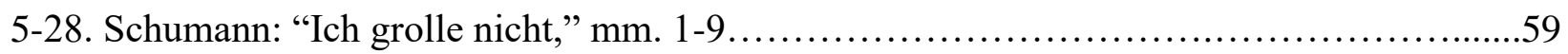

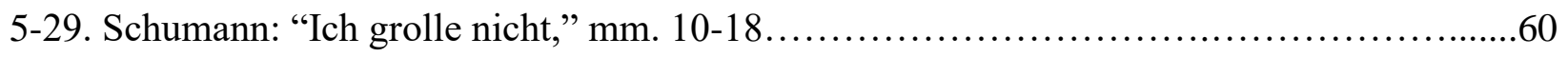

5-30. Schumann: "Ich grolle nicht," mm. 19-27 ..............................................61

5-31. Schumann: "Ich grolle nicht," mm. 28-32 ........................................62

5-32. Schumann: "Ich grolle nicht," mm. 32-36 .............................................63

5-33. Schumann: "Und wüssten's die Blumen die Kleinen,” mm. 1-8 .........................66

5-34. Schumann: "Und wüssten's die Blumen die Kleinen," mm. 24-32 .......................68

5-35. Schumann: "Und wüssten's die Blumen die Kleinen,” mm. 30-37 .......................69

5-36. Schumann: "Das ist ein Flöten und Geigen," mm. 1-16_...............................72

5-37. Schumann: "Das ist ein Flöten und Geigen," mm. 14-34_................................74

5-38. Schumann: "Das ist ein Flöten und Geigen," mm. 63-84 .................................76

5-39. Schumann: "Hör' ich das Liedchen klingen," mm. 1-8 ....................................

5-40. Schumann: "Hör' ich das Liedchen klingen," mm. 9-12 ............................... 80

5-41. Schumann: "Hör' ich das Liedchen klingen," mm. 13-18 .................................... 81

5-42. Schumann: "Hör' ich das Liedchen klingen," mm. 17-30 ............................... 82

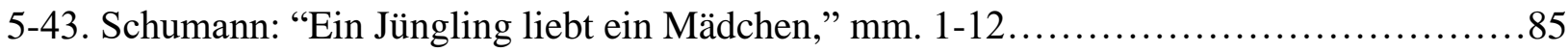

5-44. Schumann: "Ein Jüngling liebt ein Mädchen,” mm. 11-24_............................. 87

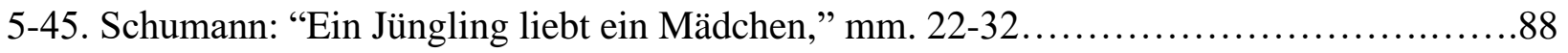

5-46. Schumann: "Ein Jüngling liebt ein Mädchen,” mm. 32-46_............................. 89

5-47. Schumann: "Am leuchtenden Sommermorgen” mm. 1-6_..............................92

5-48. Schumann: "Am leuchtenden Sommermorgen" mm. 4-11 ....................................93

5-49. Schumann: "Am leuchtenden Sommermorgen” mm. 15-20_................................94 
5-50. Schumann: “Am leuchtenden Sommermorgen” mm. 19-30 ............................96

5-51. Schumann: "Ich hab' im Traum geweinet." mm. 1-11 .................................100

5-52. Schumann: "Ich hab' im Traum geweinet." mm. 20-33 ..................................102

5-53. Schumann: "Ich hab' im Traum geweinet." Mm. 32-38 .................................103

5-54. Schumann: "Allnächtlich im Traume seh' ich dich,” mm. 1-13 ............................106

5-55. Schumann: “Allnächtlich im Traume seh' ich dich,” mm. 24-38 ..........................108

5-56. Schumann: "Aus alten Märchen winkt es" mm. 1-8 .......................................112

5-57. Schumann: "Aus alten Märchen winkt es" mm. 7-12 .................................113

5-58. Schumann: "Aus alten Märchen winkt es" mm. 13-20................................114

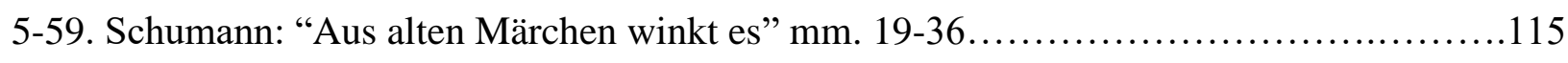

5-60. Schumann: "Aus alten Märchen winkt es" mm. 37-44 ..................................116

5-61. Schumann: "Aus alten Märchen winkt es" mm. 55-68_.................................117

5-62. Schumann: "Aus alten Märchen winkt es" mm. 67-75 .................................118

5-63. Schumann: “Aus alten Märchen winkt es" mm. 84-88 ...................................119

5-64. Schumann: "Aus alten Märchen winkt es" mm. 94-104 ............................... 120

5-65. Schumann: "Aus alten Märchen winkt es" mm. 104-113 ...............................121

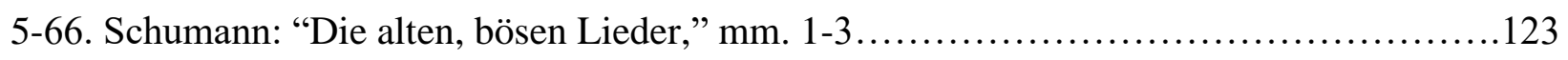

5-67. Schumann: "Die alten, bösen Lieder," mm. 1-7 ................................... 124

5-68. Schumann: "Die alten, bösen Lieder," mm. 11-15 .................................. 125

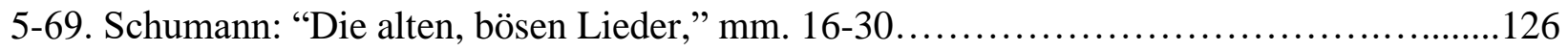

5-70. Schumann: "Die alten, bösen Lieder," mm. 31-35 .................................. 127

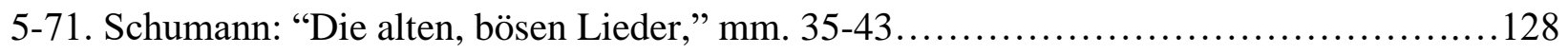

5-72. Schumann: "Die alten, bösen Lieder," mm. 44-52 ..................................... 129

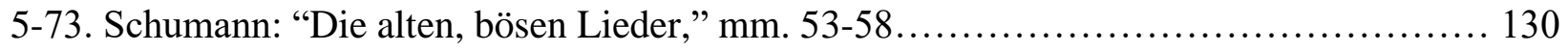

5-74. Schumann: "Die alten, bösen Lieder," mm. 59-67 .................................... 132 


\section{CHAPTER I}

\section{INTRODUCTION}

The primary focus of this paper is to provide an analysis of Robert Schumann's Dichterliebe offering historical information and insights into each of the sixteen songs. The analysis includes the English translation of the texts and discussion of the form of each song as well as highlighting the special moments of harmonic, rhythmic and melodic structure in relation to Schumann's settings of each poem. The analysis provides a foundation for collaborative skills for the singer and pianist for the study and performance of Dichterliebe. In addition, the paper includes brief biographies of Robert Schumann and Heinrich Heine and background information on the poetry and the development of the cycle. Two appendices provide information on historic and current recordings of Dichterliebe and the available editions.

Numerous books, articles, and research papers have been written about Dichterliebe. However, few offer comprehensive insight into this song cycle which is the main objective of this paper. Some of the selected writings include the following:

In 1957, Hubert Neil Davidson wrote his thesis for the degree of Master of Music, entitled "Dichterliebe by Robert Schumann." 1 This paper focuses on characteristics of each song, including harmonic structure, rhythm, and dynamics and the collaborative role of the piano.

Arthur Komar published Robert Schumann: Dichterliebe ${ }^{2}$ in 1971. In this book, Komar analyzes the music of Dichterliebe as a whole and in its parts. Furthermore, Komar includes brief

\footnotetext{
${ }^{1}$ Davidson, H. Neil, “Dichterliebe by Robert Schumann.” (Master's thesis, North Texas State College, 1957).

${ }^{2}$ Arthur Komar, ed., "Robert Schumann: Dichterliebe." (New York: W· W· Norton \& Company, 1971).
} 
analysis of some of the songs by other theorists including Heinrich Schenker, Allen Forte, and Felix Salzer.

The German Lied and Its Poetry ${ }^{3}$ includes a chapter on piano accompaniments which features each of the sixteen individual songs of Dichterliebe. This chapter provides integral background information on Heine's poetry and focuses on the poetic analysis as inspiration for Schumann's musical details. This chapter describes the special features and unique style of each song.

In 1991, Richard Douglas Layton wrote his doctoral dissertation, "Large-Scale Tonal

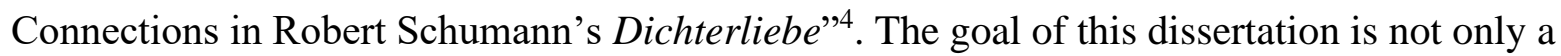
detailed study of the structure of each song, but also a Schenkerian analysis of the cycle as a whole. In addition, Layton demonstrates the close relationship between the text and the music.

An article in the journal Music Theory Spectrum, Vol. 4, entitled "Organic Structure and the Song Cycle: Another Look at Schumann's Dichterliebe" ${ }^{25}$ introduces a novel concept: that analyzing and criticizing music may be united as in aspects of Hegel's approach to philosophy. David Neumeyer primarily attempts to convey the conception of organic unity and utilize Schenker's approach to demonstrate Dichterliebe as an organic structure of multiple movements.

The website Schumannuary ${ }^{6}$ includes elaborate analysis of each song of Dichterliebe with English translations, including the structure, mood, harmonic progression, text setting, and

\footnotetext{
3 Elaine Brody and Robert A. Fowkes, "The New Style of Piano Accompaniments," in The German Lied and Its Poetry. (New York: New York University Press, 1971), 99-127.

4 Layton, R. Douglas, "Large-Scale Tonal Connections in Robert Schumann's Dichterliebe." (Ph.D. diss., University of Maryland, 1991).

${ }^{5}$ David Neumeyer. "Organic Structure and the Song Cycle: Another Look at Schumann's Dichterliebe." Music Theory Spectrum, Vol. 4 (1982): 92-105.

${ }^{6}$ Emilia De Leo, Schumannuary, https://schumannuary.wordpress.com/?s=im+wundersch (accessed August 20, 2020).
} 
key relationship. Emilia De Leo published the articles about each of the sixteen songs between January 5, 2016 and January 22, 2016, describing the special features of each musical setting and their close association with the poems.

In his 2014 doctoral dissertation, "Schumann and the Development of the Collaborative Relationship between Voice and Piano in Opus 48 Dichterliebe," ${ }^{, 7}$ Scott Wichael demonstrates the importance of collaboration by using six songs of the cycle as examples. The author emphasizes that Dichterliebe was composed during Schumann's "song year" and that Schumann's collaborative maturity using the voice and the piano can be discovered by the six examples.

Dichterliebe is one of the most frequently performed song cycles. It represents a groundbreaking revolution for the song cycle genre. ${ }^{8}$ With art songs composed before Schumann, the interpretation of the poetry is typically transmitted by the voice, and the thematic background is conveyed by the piano, which offers text painting, accompaniment, harmonic, and mood changes. ${ }^{9}$ Schumann's innovations are exemplified in Dichterliebe, with the wide range of vocal styles and piano figurations in each song. More significantly, the piano reaches an equal importance to the voice for the first time, sometimes even surpassing it. ${ }^{10}$ This paper offers a comprehensive analysis of Dichterliebe, providing the singer and pianist a concise resource for study and interpretation. This paper aims to acknowledge the importance of collaboration

\footnotetext{
${ }^{7}$ Wichael, Scott, "Schumann and the Development of the Collaborative Relationship between Voice and Piano in Opus 48 Dichterliebe." (D.M.A. diss., University of Kansas, 2014).

${ }^{8}$ Whitton, Kenneth. "The Development of the German Lied,", in Lieder: An Introduction to German Song (Great Britain: Julia MacRae Books A division of Franklin Watts, 1982): 54.

${ }^{9}$ Wichael, Scott, "Schumann and the Development of the Collaborative Relationship between Voice and Piano in Opus 48 Dichterliebe." (D.M.A. diss., University of Kansas, 2014), 1.

${ }^{10}$ Elaine Brody and Robert A. Fowkes, "The New Style of Piano Accompaniments," in The German Lied and Its Poetry. (New York: New York University Press, 1971), 100.
} 
between the pianist and the singer, using an analytical approach as a foundation to achieve this ultimate goal. 


\section{CHAPTER II}

\section{Brief Biography and Compositional Style of Robert Schumann (1810-1856)}

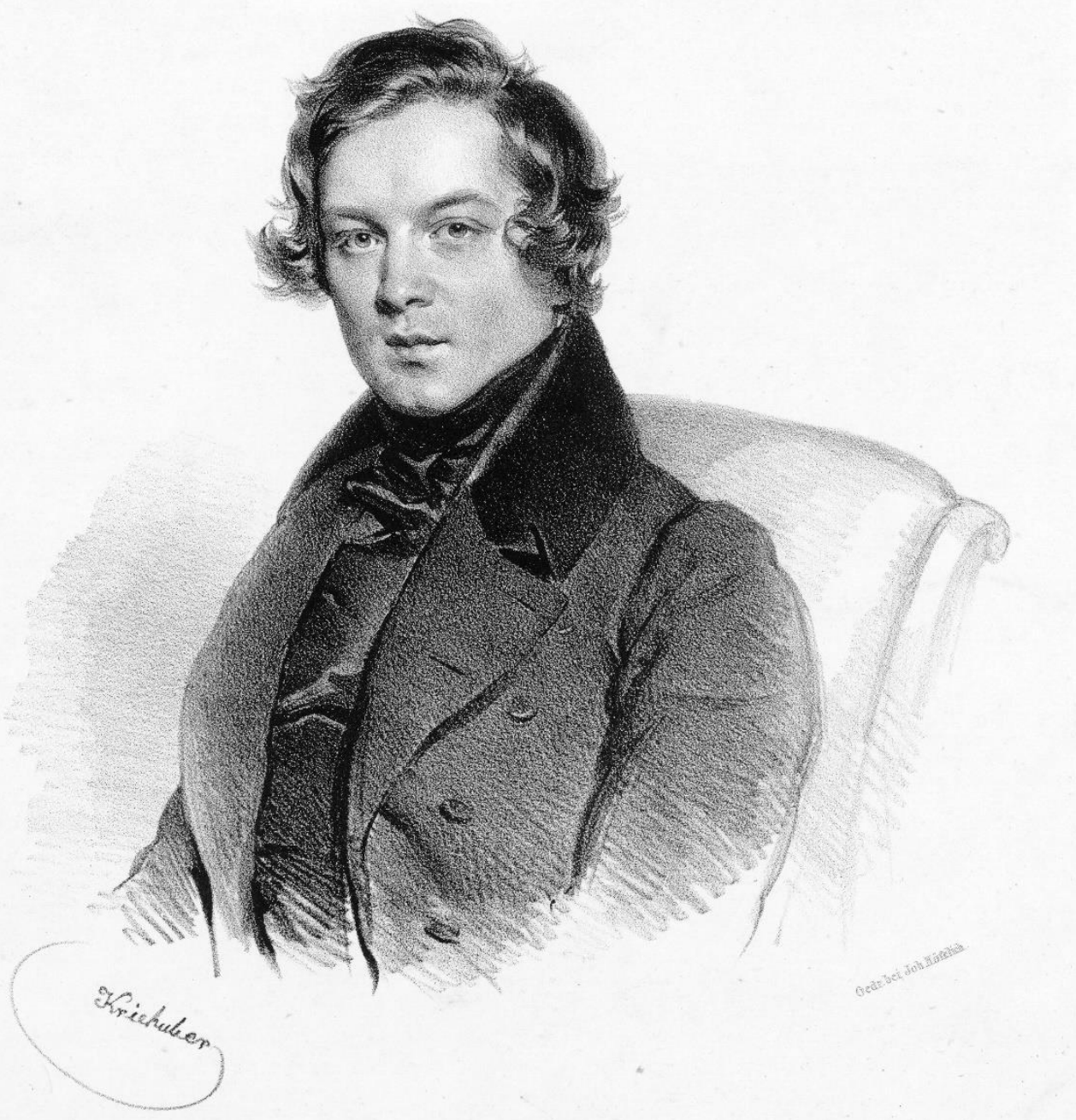

Fig. 2-1: Portrait of Robert Schumann by Kriehuber, Vienna 1839

Robert Alexander Schumann was an extraordinary German composer who lived in the nineteenth century. His life was a vivid illustration of dealing with complex relationships among them being a creative genius, having a forbidden love, and coping with psychiatric illness. Schumann was born in Zwickau in Saxony, Germany on June 8, 1810. He was the youngest 
child of August Schumann (1773-1826) who was a writer, publisher, and bookdealer, and Johanna Christiane Schumann (1767-1836). Just as Johann Ambrosius Bach (1645-1695), Leopold Mozart (1719-1787) and Franz Theodor Schubert (1763-1830) provided a cultured family environment, August provided his family the same, but with literary art instead of music. Therefore, the young Schumann grew up with a great love for literature and poetry, and he was continually cultivating a love for words and music. At the age of sixteen, Schumann could not decide whether to choose poetry or music until the grievous news of his father's death in 1826, when creating poetic music became his determination. ${ }^{11}$

Schumann's mother encouraged him to study piano, despite believing music could not be a fruitful career. In order to respect his mother's expectation of securing a stable income, Schumann enrolled in the local University of Leipzig as a law student in 1828. There he became friends with fellow student Gisbert Rosen; both shared an admiration for the author Jean Paul (1763-1825). Schumann and Rosen traveled to Munich where they met the great poet Heinrich Heine who was thirty-one. ${ }^{12}$ Heine's Buch der Lieder had received widespread popularity and later became a musical inspiration of Robert Schumann. During his study in Leipzig, Schumann met the renowned teacher Friedrich Wieck (1785-1873) and the nine-year-old Clara Wieck (1819-1896) for the first time.

After a year of studying at the University of Leipzig, Schumann spent another pleasant year studying law in the old town of Heidelberg from May 1829 until September 1830 under the jurist A.F.J. Thibau (1772-1840). As Schumann told his mother, Heidelberg had the advantage of

\footnotetext{
${ }^{11}$ Swafford, Jan, "The Romantic Period," in The Vintage Guide to Classical Music. (New York: Vintage Books, 1992). 237.

12 Taylor, Ronald, "Reluctant Student," in Robert Schumann, his life and work. (New York: Universe Books, 1982). 43.
} 
the beautiful countryside; students could divert attention from sensual and intellectual pleasures to the soul-purifying scenery. ${ }^{13}$ However, Schumann's enthusiasm for the piano grew stronger and stronger, whereas the motivation to study law was slipping away. In addition, when he was in Heidelberg, Schumann participated in many musical activities. In September 1830, Schumann quit law and returned to Leipzig to study piano and composition with Friedrich Wieck and Heinrich Dorn (1804-1892) who was only six years older than Schumann.

During his studies with Wieck, Schumann strove to perfect his piano technique and practiced intensively. At the time, Schumann was using the chiroplast, against the advice of Wieck, to try to strengthen his fingers. The device may have ultimately caused the numbness of the middle finger in his right hand. ${ }^{14}$ The dream of becoming a virtuoso pianist was shattered, and Schumann then put all his efforts into composing and writing. In 1831, Schumann composed Papillons, Op. 2 for solo piano, a cycle of character pieces which offered Schumann's new perspective on piano writing and expression.

\section{In late March 1834, Schumann established the Neue Zeitschrift für Musik (New Journal} for Music), a major accomplishment for Schumann, and his life changed due to the launch of the periodical. Schumann took the position of editor and chief critic for ten years at the periodical which acted as the most significant voice of advanced musical thinking in Germany. ${ }^{15}$ While Schumann was developing the New Journal for Music, he was also composing productively including his piano compositions such as Carnaval, Op. 9 (1835), Fantasiestücke, Op.12 (1837),

\footnotetext{
13 Ibid., 54.

${ }^{14}$ Daverio, John, and Eric Sams." The decision for music: Heidelberg, 1829-30," in Schumann, Robert, Grove Music Online. 2001; accessed 28 Feb. 2021. https://doiorg.wvu.idm.oclc.org/10.1093/gmo/9781561592630.article.40704

${ }^{15}$ Swafford, Jan, "The Romantic Period," in The Vintage Guide to Classical Music. (New York: Vintage Books, 1992). 238.
} 
and Noveletten, Op. 21 (1838). Schumann experiments with piano works where the combination of literature and music creates a new connection between the two different art forms.

Furthermore, Schumann uses three identities for both journalism and music: Florestan, Eusebius, and Master Raro. The first two names were Schumann's imaginary companions that comforted him during his time of stress: the lively Florestan and a melancholy Eusebius. Master Raro is a two-name combination, the last two letters of Clara and the first two letters of Robert himself, representing maturity and wisdom.

Clara Wieck (1819-1896) was a great concert pianist, and she was the pride of her father Friedrich Wieck. Clara would be one of the first pianists to perform Schumann's work in public from memory. Even though the first encounter between Schumann and Clara was in the year of 1828 in Leipzig when she was at the age of nine, his love for Clara happened seven years later in 1835 when Clara was sixteen. In November of the same year, they devoted the first kiss to each other, however, her father discovered their trysts during the Christmas holiday, and forbid them to meet again. ${ }^{16}$ Schumann and Clara could not tolerate the decision by her father, so the two decided to see each other in secret and write letters if one of them left Leipzig. This continued for over four years. Finally, in 1840 they sued her father for the right to marry and won, resulting in their marriage on September 12, 1840. About that day, she recorded the beautiful moment in their diary by describing it as "the fairest and most momentous of my life." 17

The Schumanns' first year of marriage saw both their happy personal lives and Robert's musical expansion. His first twenty-three opus numbers were all written for piano; however,

\footnotetext{
${ }^{16}$ Daverio, John, and Eric Sams." The Davidsbündler comes of age: Leipzig, 1834-8," in Schumann, Robert, Grove Music Online. 2001; Accessed 28 Feb. 2021. https://doiorg.wvu.idm.oclc.org/10.1093/gmo/9781561592630.article.40704

17 Swafford, Jan, "The Romantic Period," in The Vintage Guide to Classical Music. (New York: Vintage Books, 1992). 238-39.
} 
Schumann suddenly wrote almost half of his total 250 Lieder during the year of 1840 , so making that year Schumann's “song year.” The poets which Schumann used for his Lieder were primarily esteemed German writers, including Henrich Heine (1797-1856), Johann Wolfgang von Goethe (1749-1832), Adelbert von Chamisso (1781-1838), Joseph von Eichendorff (17881857), Friedrich Rückert (1788-1866), and Justinus Kerner (1786-1862). Most of his Lieder are love songs including the cycles Liederkreis, Op. 24, Frauenliebe und-Leben, Op. 42, and Dichterliebe, Op. 48, they all were composed in the year of 1840 . Moreover, as a romantic composer, Schumann dedicated his collection of songs Myrthen, Op. 25 to his bride Clara as a wedding gift, which he also composed in 1840, consisting of twenty-six songs in four volumes with texts written by multiple poets. Schumann's song year represents their memorable love as well as a testament to their hard-won happiness.

As a song composer, Schumann admired Carl Loewe (1796-1869) as one of the Lied pioneers of Germany. Schumann also revered Schubert and learned from many of his ideas. Like Schubert, the attention to the melodic line was indispensable for Schuman, who also makes the piano accompaniment equally important as the voice. Schumann's new preoccupation with song symbolizes the marriage between him and Clara. In 1839 before his marriage Schumann wrote, "I have thought vocal music inferior to instrumental and have never considered it to be great art." ${ }^{\prime 18}$ It appears that his marriage to Clara not only changed Schumann's prejudice of vocal music, but also broadened his field of musical composition.

Schumann's life was almost perfect. Clara attached great importance to her husband's music creation; for example, she motivated him to compose a symphony after writing many

\footnotetext{
${ }^{18}$ Young, Percy M., "Music for Voice," in Tragic Muse; the life and works of Robert Schumann. (London: Dennis Dobson, 1961). 112.
} 
songs in $1840 .{ }^{19}$ Together, Robert and Clara had a large family, four daughters and four sons. Schumann cherished being a father, and Clara and he enjoyed spending time with their children, helping to take care of them. Schumann's composing and writing brought him close friends, including Felix Mendelssohn (1809-1847) and Johannes Brahms (1833-1897). During his career, Schumann not only produced many compositions in different genres such as symphonies and chamber works, but also wrote music reviews of his predecessors and contemporaries including Johann Nepomuk Hummel (1778-1837), Franz Schubert (1797-1828), Frédéric Chopin (18101849), Franz Liszt (1811-1886), Felix Mendelssohn (1809-1847), and more.

Behind all his precious artistic treasures, there is one thing that may have aided Schumann in his genius, but also caused his death: a mental illness which some have considered to be manic depression. The horrible disease unexpectedly became a factor, that Schumann "could only compose when he was in his manic state." 20 The early signs of mental disorder appeared in 1833 , then by 1845 , more symptoms of anxiety were evident. For example, in February 1854, two men found him in the Rhine River where he had thrown himself from a bridge; he was cold and wet when they brought him home. ${ }^{21}$ After this, Schumann was admitted to an institution in Endenich for the last two years of his life. His friends such as Johannes Brahms (1833-1897), Joseph Joachim (1831-1907) and Wilhelm Wasielewski (1822-1896) would write letters and visit him. In June 1856, when Clara heard about Schumann's circumstance of staying in bed for several weeks, she determinedly left home to see him; however, the psychiatrist Franz Richarz (1812-1887) and Brahms prevented her from seeing him.

\footnotetext{
${ }^{19}$ Swafford, Jan, "The Romantic Period," in The Vintage Guide to Classical Music. (New York: Vintage Books, 1992). 239.

${ }^{20}$ Berliner Philharmoniker, "Simon Rattle talks about Brahms and Schumann," September 22, 2014, video, 15:35, https://www.youtube.com/watch?v=yXTTIKdy5q4\&t=16s.

${ }^{21}$ Taylor, Ronald, "Disintegration and Death," in Robert Schumann, his life and work. (New York: Universe Books, 1982). 316.
} 
On July 27, Clara did see Robert who summoned his strength to embrace her and offer quiet words for the last time. ${ }^{22}$ On July 29, 1856, at forty-six years old, Robert Schumann, one of the greatest artists of the Romantic period, passed away but his music endures.

\section{Schumann's Compositional Style}

Schumann composed many large-scale works including symphonies and opera, but he may be more well-known as a miniaturist, adept at writing short pieces which he compiled to form larger works. Schumann's compositions typically consist of dramatic mood changes. For example, his character pieces and song cycles well-illustrate a wide range of moods, often quickly changing from exuberance and anguish to melancholy and wistfulness. With these mood changes, Schumann usually adopts ternary, rondo-like sectional or through-composed forms to manifest his emotional gamut. Dichterliebe and Carnaval are excellent examples of works in which Schumann uses distinct emotions in each smaller piece to create large compositions. "Schumann uses this power to transform the simplest structures, and to portray the most complex states of feeling with absurdly simple forms."${ }^{, 23}$

Even though Schumann's harmonic language is not as chromatic as such contemporaries as Chopin or Liszt, his works show an emphasis on chromatic harmonies. His harmonic language is essentially conservative with a generous use of seventh chords, mode mixture of diatonic chords and secondary dominant and leading tone chords. Schumann's genius also lies

\footnotetext{
22 Daverio, John, and Eric Sams." Endenich, 1854-6," in Schumann, Robert, Grove Music Online. 2001; Accessed 1 March. 2021. https://doi-org.wvu.idm.oclc.org/10.1093/gmo/9781561592630.article.40704

${ }^{23}$ Rosen, Charles, "Schumann," in The Romantic Generation. (Cambridge, Massachusetts: First Harvard University Press, 1998), 694.
} 
in the idea that he could make a single chord a major event. ${ }^{24}$ With regard to rhythm, Schumann tends to use a consistent rhythmic pattern for a song or section of a piece. According to Rosen, “Schumann's rhythm is obsessional: once he started a pattern he often seems unable to alter it without a considerable effort of will." ${ }^{25}$ Schumann also makes frequent use of dotted rhythms and syncopation which contribute to the Germanic folk-like character in much of his music and an unsettled romantic tension respectively.

Schumann also uses much repetition in developing a melody. He often writes in four-bar phrases, with clear periodic structure. Repetition in general is an inherent part of Schumann's compositional style, whether it be a motive, melodic fragment, or a single pitch. Another important aspect of Schumann's piano music in particular is the attention to inner voices. The texture of his piano music tends to be layered, with much emphasis on contrasting registers of the piano and sustained outer voices and intertwined accompanying figures. In general, Schumann's music is lyrical, poignant and poetic, and he is a composer who prefers a depth of expression to virtuosic displays.

\footnotetext{
${ }^{24}$ Swafford, Jan, "The Romantic Period," in The Vintage Guide to Classical Music. (New York: Vintage Books, 1992). 242.

${ }^{25}$ Rosen, Charles, "Schumann," in The Romantic Generation. (Cambridge, Massachusetts: First Harvard University Press, 1998), 683.
} 


\section{CHAPTER III}

Brief Biography and Writing Style of Henrich Heine (1797-1856)

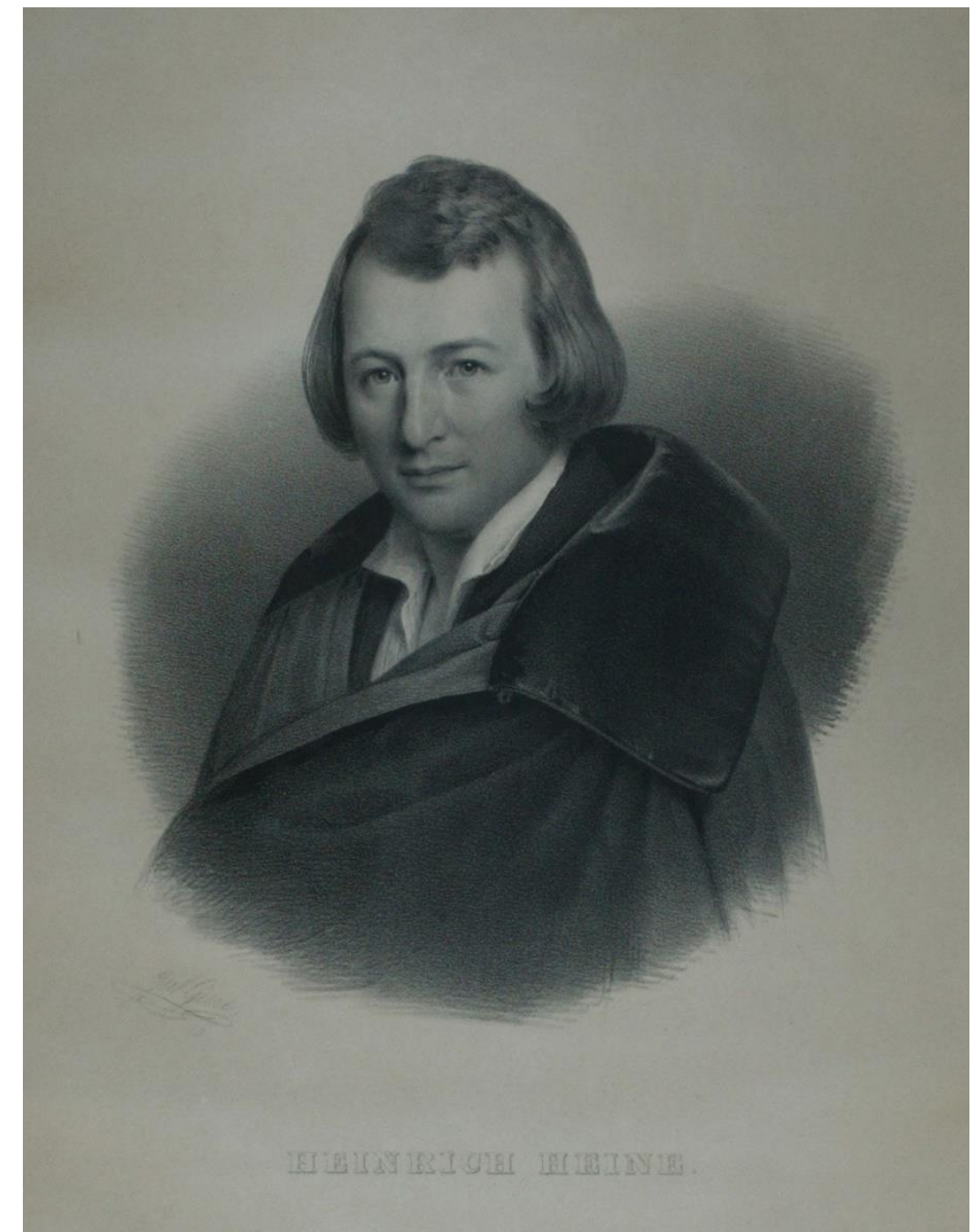

Fig. 3-1: Lithograph based on Julius Gieres's oil sketch of Heinrich Heine, 1838

Henrich Heine was a significant poet, essayist, and travel writer from Germany, and he had a tremendous impact on German literature and Jewish culture. His Buch der Lieder (1827) was one of the most influential works in the history of Germanic poetry, meanwhile, musicians would also appreciate and were inspired by this profound, monumental work. Franz Schubert 
(1797-1828), Robert Schumann (1810-1856), Felix Mendelssohn (1809-1847), Franz Liszt

(1811-1886), and other musicians were inspired by his writings.

Henrich was born to a Jewish family of moderately successful commercial background in Düsseldorf, Germany on December 13, 1797, and he was the eldest son of Samson Heine (17641828) who was an easygoing father and textile businessman, and Betty (born Peira van Geldern) (1771-1859). Heine was born eight years after the French Revolution of 1789, and Napoleon, who was his childhood hero, ruled over Europe during his childhood. Heine spent his first seventeen years happily and peacefully in his hometown of Düsseldorf. During his teens, his longing for writing poems had blossomed because the mixed cultures of German and French and religions of Judaism and Christianity had profoundly impacted him. ${ }^{26}$

At the age of eighteen, in order to cultivate young Heine's ability for business, his parents sent him to study with his uncle Salomon Heine (1767-1844). He was an extremely wealthy banker in Frankfurt, where the young Heine met and developed an obsession with his uncle's daughter, his first cousin, Amalie. She did not reciprocate; therefore, the unrequited love died a natural death. Heine spent another three years in Hamburg, and his efforts proved to his family that he had no interest or talent for business. In 1819, his parents permitted him to study law at the University of Bonn. Heine also lacked interest in law, and he instead spent a great deal of time studying poetry and literature, and deeply thinking about his Jewish identity. While Heine was in college, his financial support was not only from the generosity of his uncle, but also the publisher Julius Campe (1792-1867) who offered him an opportunity to make a living from his craft. ${ }^{27}$ Heine also transferred to colleges in Göttingen and Berlin to focus on legal studies. While

\footnotetext{
${ }^{26}$ Spencer, Hanna, "Biographical Background," in Heinrich Heine. (Boston: Twayne Publishers, 1982). 2.

${ }^{27}$ Ibid., 4.
} 
Heine was in Berlin between 1821 and 1823, he met two influential people, the writer and diplomat Karl August Varnhagen (1785-1858) and his wife Rahel Varnhagen (1771-1833), who held one of the most famous salons in Europe which Heine frequented. The Varnhagens befriended Heine and became his most loyal supporters.

During his time in Berlin, Heine joined the Verein für Kultur und Wissenschaft der Juden (Society for the Culture and Science of the Jews), and he met several important people in Berlin, including Leopold Zunz (1794-1886), Heinrich Graetz (1817-1891), and Edward Gans (17971839) who was a primary initiator and remarkable student of Georg Wilhelm Friedrich Hegel (1770-1831). It was also at this time that Heine heard of Hegel, who became the most admirable, influential person in Heine's life, and he led the young poet to philosophy, which gave him a profound perspective on writing poetry. ${ }^{28}$ In Heine's youth, the inspiration of writing verses originated from his environment, where he was inundated with a mixture of tradition between cultures and religions. However, Hegel's appearance inspired the thought of eulogizing historical process, and a progressive conception from religion to philosophy. ${ }^{29}$ Buch der Lieder (Book of Songs) and Reisebilder (Travel Sketches) are the two large works containing this new philosophical influence on Heine.

In 1825, Heine retuned to Göttingen to complete his studies and ultimately received a Doctorate degree in law. Next, in June, he went to Heiligenstadt, near Göttingen, to be baptized as he converted from Judaism to Christianity. As early as his childhood, Heine had already disliked his identity of being a Jew and considered himself a Christian. However, he could not reveal he was considering leaving the faith because his wealthy uncle would stop supporting

\footnotetext{
${ }^{28} \mathrm{Ibid}$., p. 5.

${ }^{29} \mathrm{lbid}$.
} 
him, and he would bear a betrayal of his ancestors. ${ }^{30}$ In the nineteenth century, Heine's Jewish identity contradicted with the European cultural norms; Jews had suffered tremendous pressure from many restrictions and discriminations. Therefore, after experiencing many psychological struggles, Heine ultimately decided to convert to Christianity, although almost immediately regretting it.

After being baptized, Heine took a short trip not far from home, during which he wrote the journal Die Harzreise (Journey through the Harz). Two years later in 1827, while he was in England, Heine had received his first job offer by Baron Johann Friedrich von Cotta (1764-1832) to be a co-editor for a new journal in Munich, Germany. He accepted the job, but only for six months, since his desired career was to be a professor at the University of Munich. ${ }^{31}$ Soon afterwards, Heine took a long trip and traveled to many cities in Italy, which foreshadowed his great work, Italian Travel Sketches. Meanwhile, Heine received shocking and sad news that his father had died, a fact Heine could not bear. He felt extremely depressed and seriously considered where he should settle down. Fortunately, his mother was settled in Hamburg and was supported by his uncle Salomon, so Heine went there for a short stay. In 1831, he left for Paris, France.

While he was in Paris, the Saint-Simonist movement, which was a French political, religious, and social movement in the first half of the nineteenth century, was at the height of its power and splendor in France. Heine took part in several meetings in support of members and speakers. Then, Heine also published one of his most elaborate essays entitled The Salon of 1831, which is featured in the journal Augsburger Allgemeine Zeitung, which developed new

\footnotetext{
${ }^{30}$ François, Fejtö, “Heine's Conversion," in Heine: A Biography, trans. Mervyn Savill (London: Allan Wingate, 1946). 116.

${ }^{31}$ Spencer, Hanna, "Biographical Background," in Heinrich Heine. (Boston: Twayne Publishers, 1982). 7.
} 
aesthetics for the entirety of Europe. ${ }^{32}$ Heine became a major contributor to the journal in the first half of the nineteenth century, and the articles involved many aspects such as French life and German policy.

Between work and entertainment, Heine's life moved rapidly. However, in 1834, Heine encountered the love of his life on a typical autumn afternoon while he was walking into a glove shop in the Passage Choiseul. The beautiful girl was Crescence Eugenie Mirat (1815-1883). According to the description of Fejtö: "She was a ripe, fresh country wench, full of Parisian grace." ${ }^{33}$ Heine and Mirat eventually married in 1841 after a long period of seven years. After marriage, Heine tended to call her Mathilde.

In May 1842, when Heine was in Paris, he heard the astounding news from Germany that a great fire broke out in Hamburg. Heine could hardly rest and anxiously awaited his mother's letter. Fortunately, his mother and uncle were safe. For twelve years, Heine had not returned home. He became more concerned about his mother and planned to visit Germany to look after her. Before leaving, Heine met Karl Max (1818-1883) in Paris. In November of 1843, Heine overcame two major obstacles: the Prussian authorities and health issues including trouble with his eyesight. He then departed from Paris for Germany after saying farewell to Mathilde. ${ }^{34}$ His elderly mother was overjoyed when she met her son because they had not seen each other for so long. In 1844, Heine traveled with his wife Mathilde to Hamburg, and his uncle Salomon died in December of that year. Heine's health was diminishing in part because of the bitter quarrel with

\footnotetext{
${ }^{32}$ François, Fejtö, "Paris in 1831," in Heine: A Biography, trans. Mervyn Savill (London: Allan Wingate, 1946). 155.

33 Ibid., p. 186.

${ }^{34}$ Ibid., p. 225.
} 
Salomon's family over inheritances; they were afraid that Heine might expose something private that even justified inspection of Heine's writing. ${ }^{35}$

In 1848, Heine became ill in Paris after the February Revolution in France. He spent his last years suffering from his slowly deteriorating body. His friends would come to visit him, and he could see them only when he held one of his eyes open. ${ }^{36}$ Even more severe symptoms appeared at the beginning of 1856, and Heine suffered immensely, especially at night. Heine could not sleep due to asthma attacks, stomach cramps, and intestinal problems. Those symptoms tortured him until his death on February 17, 1856. He was buried in Montmartre in Paris as he wished. When Heine was alive, he asked for a small statement on his tombstone: "Here lies a German poet." 37

\section{Heine's Writing Style}

Henrich Heine is considered one of the greatest poets in German history, and he also achieved the reputation as a travel writer, haivng journeyed to many places to immerse himself in society and culture such as England, Italy, France, and throughout Germany. His lyric poetry contains a strong sense of Romanticism, and his Romantic irony was one of his most distinguishing styles. In the second collection Lyrisches Intermezzo of Buch der Lieder, more than half of the poems are related to unrequited love, and many of his poems were ruthlessly and

\footnotetext{
35 Spencer, Hanna, “Biographical Background," in Heinrich Heine. (Boston: Twayne Publishers, 1982). 11.

${ }^{36}$ Henry Abramson, "Heinrich Heine: Poet of Judenschmerz Jewish Biography as History Dr. Henry Abramson," March 20, 2014, video, 49:31, https://www.youtube.com/watch?v=aMKW8KwoN-U\&t=960s.

37 Spencer, Hanna, "Biographical Background," in Heinrich Heine. (Boston: Twayne Publishers, 1982 ). 11.
} 
sarcastically aimed at vainglorious women. Two other main subjects are also found throughout Heine's ironic writing: racial discrimination and villains.

Among the poems in Buch der Lieder, a common characteristic that Heine frequently adopted was dramatic mood change. He would write verses with anguished mood, then switch to a completely opposite emotion toward the end; he would use expressive words and delicate language to describe a dream, but the real world mostly would be cruel. "Heine's talent for establishing mood with a few vivid strokes was matched only by his flair for breaking it." 38 His Travel Sketches, which consists of four collections, shows his generally regarded keen sense of imagination and incisive wit. These prose works not only reflect Heine's imagination in describing splendid landscapes, but also his skill at discussing politics by using his profound knowledge and intellectual style of writing.

Social politics was a power that stimulated Heine in his writing. He glorifies Napoleon, ironically criticizes the German restoration, and straightforwardly reveals the drawbacks of British Capitalist Industrialization. Travel Sketches embodies the course of his intellectual and political development, and Heine had thought of an advanced ideology. With sexuality, religion, and social politics, Heine genuinely considered himself liberated from those three constraints. ${ }^{39}$ His thinking was inspired by a German Philosopher Georg Wilhelm Friedrich Hegel (17701831), and the purpose of his pursuing it was not only for his writing possibilities, but also promoting growth as a human being.

\footnotetext{
${ }^{38}$ Spencer, Hanna, "Book of Songs," in Heinrich Heine. (Boston: Twayne Publishers, 1982). 23.

${ }^{39} \mathrm{lbid}$, p. 48.
} 


\section{Chapter IV}

\section{Origins of Dichterliebe (1840)}

On May 24, 1840, Schumann began working on a collection of songs with poetry by Heinrich Heine. He completed his manuscript of 20 songs within ten days and immediately offered it to the publisher Bote \& Bock, who turned it down because of its length (by Schumann's estimation, 48 pages).$^{40}$ In 1843 , Schumann tried again to have the songs published with the title "Twenty Songs and Airs from H. Heine's Buch der Lieder for Voice and Piano Accompaniment, op. 47", and sent it to the Peters publishing firm. ${ }^{41}$ In 1844 , Peters published the first edition of Dichterliebe, op. 48 with 16 songs in two volumes. It remains unknown why Schumann removed four songs and changed the title to Dichterliebe, but the popularity of the songs was immediate. ${ }^{42}$ At first, the songs were frequently performed separately, and several were published independently in addition to the two volumes. Clara Schumann gave the first performance of "Ich grolle nicht" with German soprano Livia Frege (1818-1891), and the whole cycle was performed in public for the first time in 1861 by the baritone Julius Stockhausen (1826-1906) and accompanied by Johannes Brahms (1833-1897). Schumann dedicated the song cycle to Wilhelmine Schröder-Devrient (1804-1860), a well-known German operatic soprano of her times, and, in Schumann's words, a "great artist." 43

\footnotetext{
${ }^{40}$ Ozawa, Kazuko, ed., Dichterliebe, op. 48, composed by Robert Schumann. Munich, Germany: G. Henle Verlag, 2005, p. viii.

${ }^{41}$ Ibid., ix.

$42 \mathrm{lbid}$.

${ }^{43} \mathrm{lbid}, \mathrm{p} . \mathrm{x}$.
} 
All the poems of Dichterliebe are from the second collection Lyrisches Intermezzo ("Lyric Intermezzo") from Heinrich Heine's Buch der Lieder. Heine wrote the first poems in 1813 when he was sixteen, but a large portion of the poems were written between 1821 and 1824; Buch der Lieder was published in $1827 .^{44}$ The entire volume is divided into five collections: Junge Leiden ("Young Sorrows"), Lyrisches Intermezzo ("Lyric Intermezzo"), Die Heimkehr ("Homecoming"), Aus der Harzreise ("Song from the Harz-Journey"), and Die Nordsee ("The North Sea"). Heine devoted himself to the monumental work for over a decade, and he not only achieved widespread popularity as a poet, but also completed a work which contributed hundreds of texts for composers. Schumann was one of the beneficiaries.

For Dichterliebe, Schumann chose the poems from the second collection Lyrisches Intermezzo, a set of sixty-six lyric poems which Heine first published in 1823 when he was twenty-five years old. However, Heine made many alterations in the later versions of this set, for example, adding "Im wunderschönen monat mai" as its new first poem and "Ich grolle nicht" and two other poems from Minnelieder, an earlier collection of 1822. He also removed five other poems, then released a final edition of Buch der Lieder with sixty-five poems. ${ }^{45}$

The table below shows the order of the poems in Lyrisches Intermezzo, and the difference between manuscript and the first edition of Dichterliebe (see Figure: 4-1):

\footnotetext{
${ }^{44}$ Spencer, Hanna, "Book of Songs," in Heinrich Heine. (Boston: Twayne Publishers, 1982). 12.

${ }^{45}$ Arthur Komar, ed., "Robert Schumann: Dichterliebe." (New York: W. W. Norton \& Company, 1971). 3-4.
} 


\begin{tabular}{|c|c|c|}
\hline \multicolumn{3}{|c|}{$\begin{array}{c}\text { Order of Poems in Lyrisches Intermezzo and } \\
\text { Dichterliebe }\end{array}$} \\
\hline \multirow{2}{*}{$\begin{array}{c}\text { Lyrisches } \\
\text { Intermezzo (1827) }\end{array}$} & \multicolumn{2}{|c|}{ Dichterliebe } \\
\hline & $\begin{array}{l}\text { Manuscript } \\
(1840)\end{array}$ & $\begin{array}{l}\text { First edition } \\
\text { (1844) }\end{array}$ \\
\hline 1 & 1 & 1 \\
\hline 2 & 2 & 2 \\
\hline 3 & 3 & 3 \\
\hline 4 & 4 & 4 \\
\hline 5 & 5 & \\
\hline 6 & 6 & \\
\hline 7 & 7 & 5 \\
\hline 11 & 8 & 6 \\
\hline 18 & 9 & 7 \\
\hline 20 & 11 & 9 \\
\hline 22 & 10 & 8 \\
\hline 39 & 13 & 11 \\
\hline 40 & 12 & 10 \\
\hline 43 & 19 & 15 \\
\hline 45 & 14 & 12 \\
\hline 46 & 15 & \\
\hline 54 & 16 & \\
\hline 55 & 17 & 13 \\
\hline 56 & 18 & 14 \\
\hline 65 & 20 & 16 \\
\hline
\end{tabular}

Figure 4-1. Table of Poems in Lyrisches Intermezzo and Dichterliebe

The main theme of this collection is unrequited love, an unpleasant love story where a poet is betrayed by his lover. Before writing the second collection, Heine developed an obsession with his first cousin Amalie, but she rejected him and married another man. ${ }^{46}$ The unrequited love had tremendous impact on Heine, which prompted him to write Lyrisches Intermezzo.

\footnotetext{
${ }^{46}$ Kimball, Carol, "Part II Literature: German Composers," in Song: A Guide to Art Song Style and Literature. (Milwaukee: Hal Leonard Corporation, 2006), 78.
} 
Schumann called Clara "the guardian angel of his genius." ${ }^{27}$ To Schumann, she was not only a significant life partner, but also a musical confidant. In 1834, Clara composed Piano Concerto in A minor, Op. 7 when she was fifteen years old. This particular piece, precisely, the second movement Romanza, sheds light on Schumann's Dichterliebe which was composed six years later in 1840. Firstly, Romanza is in ternary form, and Clara applied harmonic instability within the B section, and she alternates between the two keys of A major and F-sharp minor in this section. The melody is astonishingly similar to the opening of the most symbolic lied of Dcihterliebe "Im wunderschönen Monat Mai." The alternation between tonal centers of F-sharp minor and A major also exists as a musical connection between Robert's song and Clara's piece. ${ }^{48}$ Looking beyond the score of the second movement of Clara's Piano Concerto, Robert might have felt his life was incomplete without her and his music was incomplete without hers (see Figures 4-2 and 4-3):

\footnotetext{
${ }^{47}$ Swafford, Jan, "The Romantic Period," in The Vintage Guide to Classical Music. (New York: Vintage Books, 1992). 239.

${ }^{48}$ Hope College, "Music Department |Presentation on Schumann's "Dichterliebe"," October 8, 2020, video, 50:44, https://www.youtube.com/watch?v=E-LnAmJwikY\&t=829s.
} 

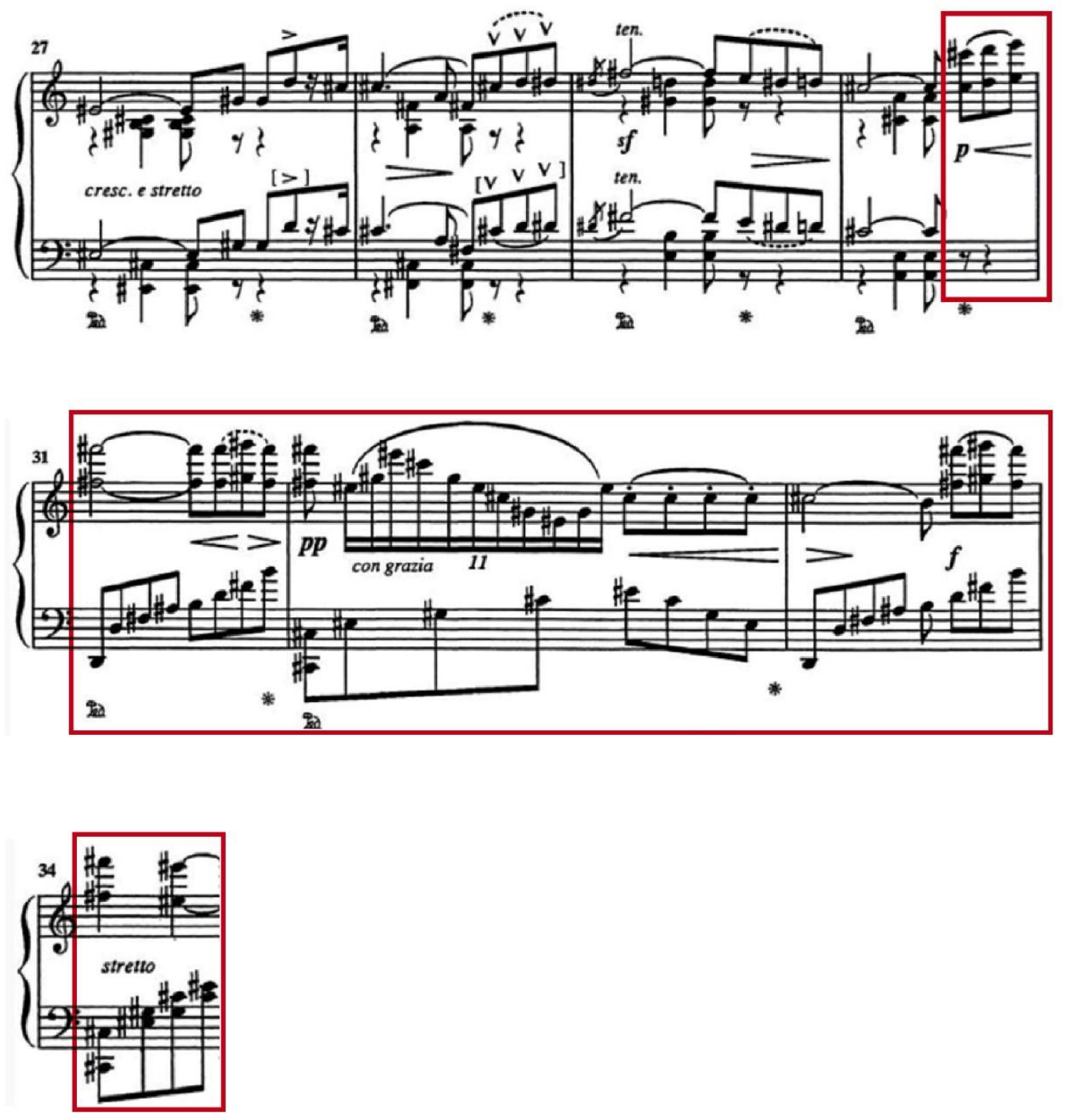

Figure 4-2. Clara Piano Concerto, Op.7, movement 2, mm. 27-34. 

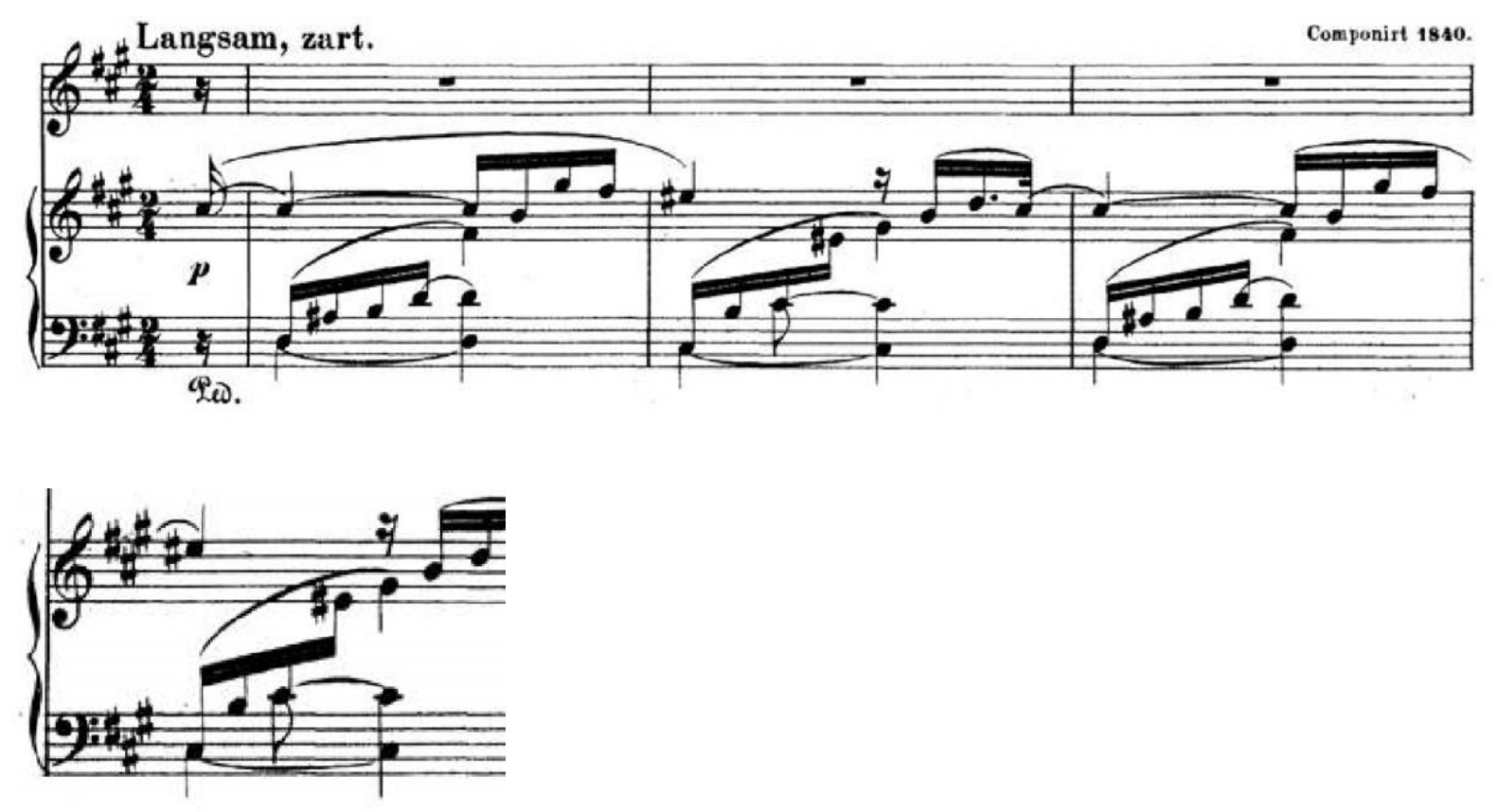

Figure 4-3. Schumann: "Im wunderschönen Monat Mai,” mm. 1-4

Dichterliebe blends of a variety of emotions, and the interpretation of the poetry is transmitted by both the voice and the piano. Schumann demonstrates Heine's poetry in his music both logically and emotionally. Unrequited love is the principal theme which Schuman explores through ideas of infatuation, beauty, anger, despair, irony, imagination, delusion, dreams, forgiveness, and reconciliation. Dichterliebe represents the process of a poet's love, and as Kimball declares: "It is an intimate poetic journey, psychological as well as emotional."49 Schumann uses this song cycle as a journey to illustrate a poet's love, and whether it is representative of everyone's love or unique to a poet remains unanswered but is part of what makes the cycle so enduring.

\footnotetext{
${ }^{49}$ Kimball, Carol, "Part II Literature: German Composers," in Song: A Guide to Art Song Style and Literature. (Milwaukee: Hal Leonard Corporation, 2006), 79.
} 


\section{CHAPTER V}

\section{Analysis of Dichterliebe, op. 48}

\section{Im wunderschönen Monat Mai}

Im wunderschönen Monat Mai, als alle Knospen sprangen, da ist in meinem Herzen die Liebe aufgegangen.

Im wunderschönen Monat Mai, als alle Vögel sangen, da hab' ich ihr gestanden mein Sehnen und Verlangen.
In the wondrously beautiful month of May, When all the buds were springing open, Love rose up In my heart.

In the wondrously beautiful month of May, When all the birds were singing, I confessed to her My longing and my desire. ${ }^{50}$

Key: F-sharp minor

Form: Strophic

Accompanying Style: Arpeggiated, layered

Predominant Characteristics of Vocal Line: Narrow range, repetitive 2-bar structure

In this first poem, Heine uses a rhetorical speech to express the poet's love as flower buds sprang and birds sang in the spring. However, "Im wunderschönen Monat Mai” is not joyful, but sets an unsettled mood for a confession of longing and desire by the poet for his beloved. As the beginning of the collection Lyrisches Intermezzo, "it preceded by a "Prolog," in which the poet appears as an old knight who lives on dreams of his past love." ${ }^{51}$ For "Im wunderschönen Monat

\footnotetext{
50 Glass, Beaumont, Schumann's complete song texts. (Genesco, NY: Leyerle Publications, 2002). 62-3.

${ }^{51}$ Hallmark, Rufus E., "The Genesis of Dichterliebe," in The Genesis of Schumann's Dichterliebe. (Michigan: UMI Research Press, 1976), 36.
} 
Mai," Schumann uses a two-verse strophic form in the key of F-sharp minor with A major as another important tonality. The mutual transformation between A major and F-sharp minor conveys the ambiguous tonality that shows the poet's emotional state and represents the true essence of Dichterliebe.

Schumann uses "Langsam, zart" as the tempo marking which means slow and tender. He uses winding sixteenth notes and a quiet dynamic to create a four-measure introduction to represent a beautiful scene, which contains a repetitive two-bar motive with a sotto voce timbre. The opening C-sharp, an unprepared suspension, and the layered arpeggiated sixteenth notes, which reflect the movement of the delicate flowers, create an unsettled yearning (see Figure 5-1):
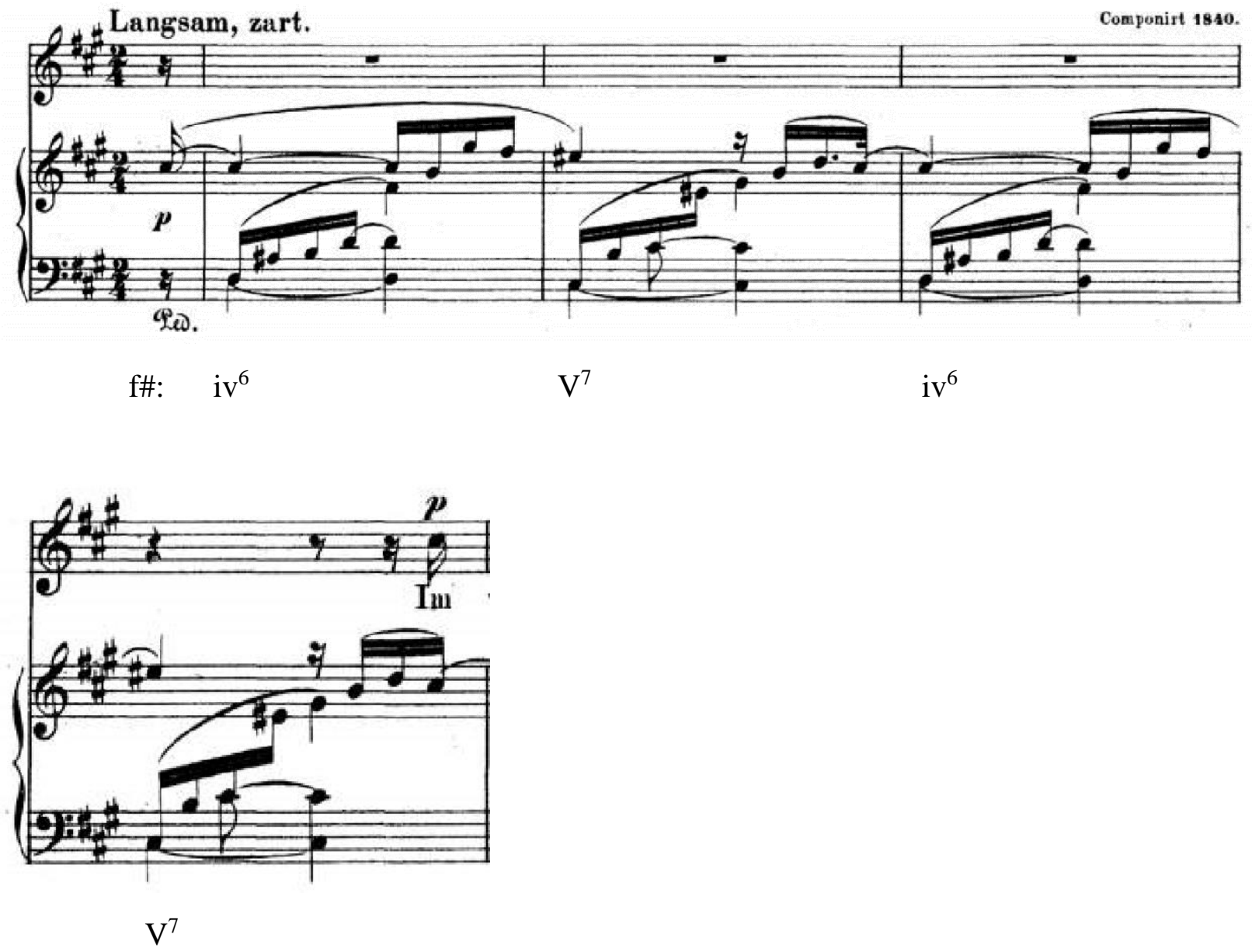

Figure 5-1. Schumann: "Im wunderschönen Monat Mai," mm. 1-4 
However, when the vocal line enters in measures five through eight, Schumann uses a solid tonality in A major (ii $\left.{ }^{6}-\mathrm{V}^{7}-\mathrm{I}\right)$, which also contains a repetitive phrase in each of the two bars, but it is different from the introduction. Here, the poem describes the beautiful month of May, when all the flower buds are springing open; Schumann employs a bright A major tonality to depict this splendid sight (see Figure 5-2):
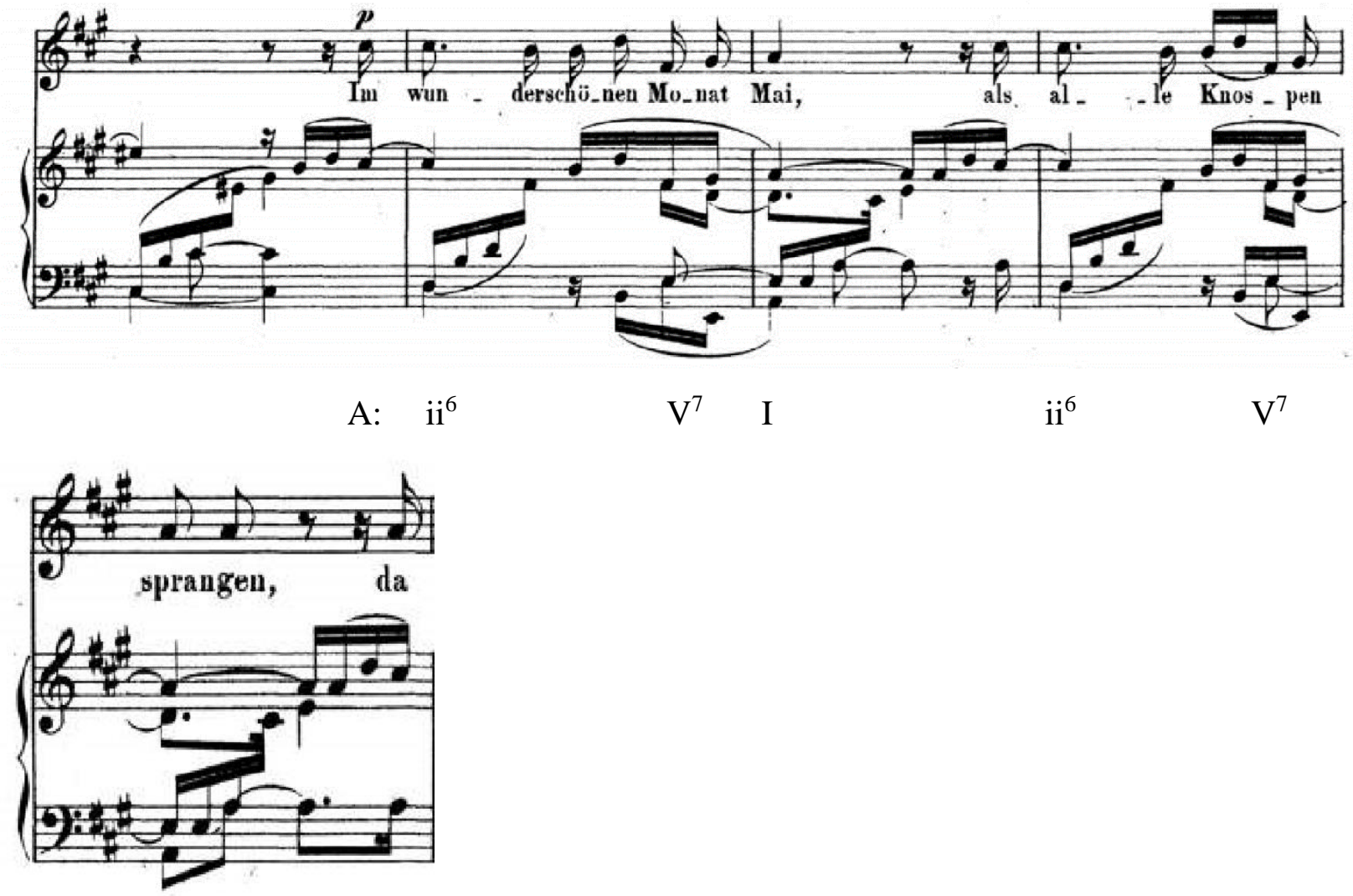

A: I

Figure 5-2. Schumann: "Im wunderschönen Monat Mai,” mm. 4-8

Moreover, Schumann took advantage of a dotted rhythm with the ascending melodic line in measures 9 through 12 (as well as the later measures 20 through 23) to emphasize the poet's 
yearnings. In this passage, Schumann also uses a sequence, two tonicizations in B minor and D major to represent the text, as the poet's love rose up in his heart (see Figure 5-3):

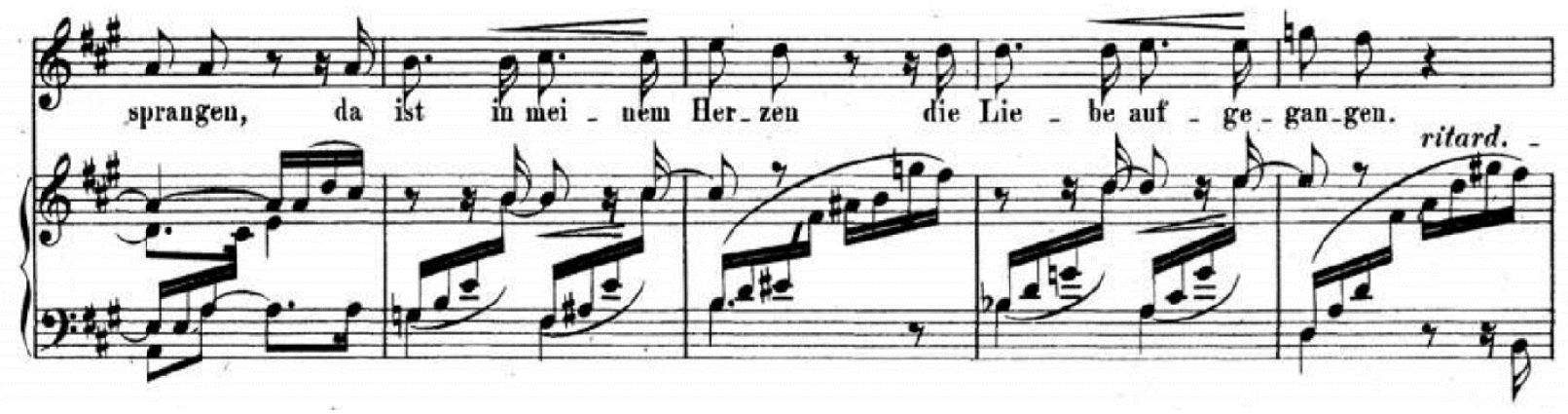

A: I I

b: vii $\quad$ iv $^{6} \quad \mathrm{~V}^{7} \quad$ i $\quad$ i

D: vi iv $\quad \mathrm{V}^{7} \quad \mathrm{I}$

Figure 5-3. Schumann: “Im wunderschönen Monat Mai,” mm. 8-12

The second verse is a musical repetition of the first joined by a brief interlude. In the postlude, the song returns to the home key of F-sharp minor in measure 23. At the end of the song in measure 26, Schumann uses a C-sharp dominant chord, the unresolved $\mathrm{V}^{7}$ to represent the poet's unfulfilled longing and desire as well as an anticipation of the next song (see Figure 54): 


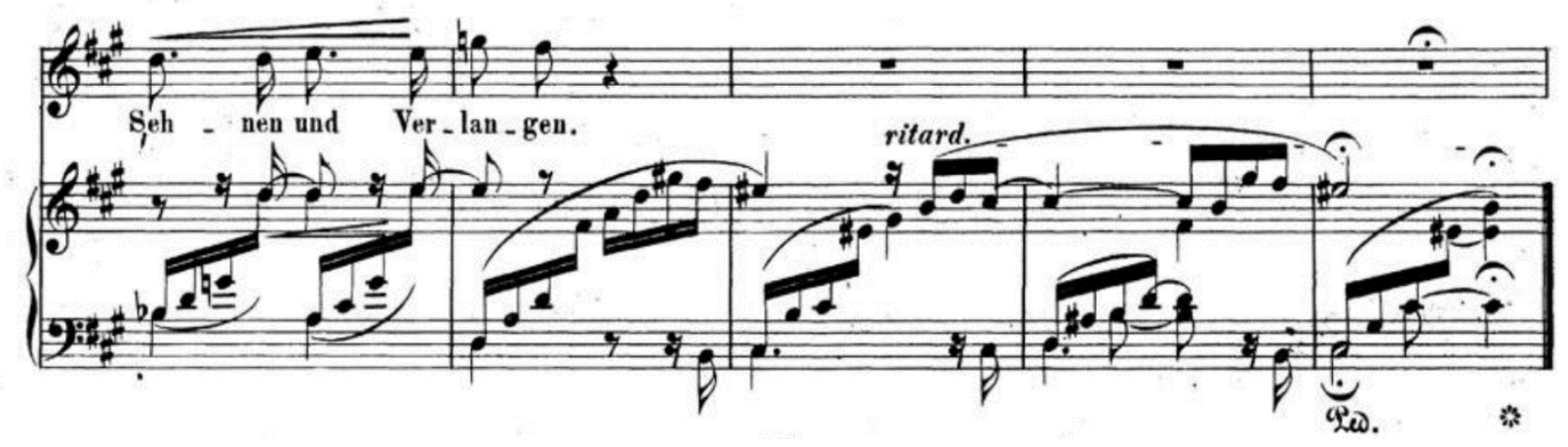
A: $\quad$ iv $6 / I V \quad V^{7} / I V$
IV
f\#: VI
$\mathrm{V}^{7}$
iv 6
$\mathrm{V}^{7}$

Figure 5-4. Schumann: “Im wunderschönen Monat Mai,” mm. 22-26

Schumann possessed the ability to musically illustrate the genuine meaning of a poem.

The ambiguous tonality between F-sharp minor and A major in the first song represents the complex love of the poet. In addition, in the piano writing, he uses the sixteenth-note ascending motion to depict the buds springing, and Schumann consistently uses an arpeggiated accompanying pattern with a layered inner voice throughout the song. The accompaniment doubles some of the melody when the voice enters but retains an independence through the many layers. Moreover, Schumann's use of repetition is a crucial characteristic of the song, as the repetitive two-bar structure gives it a simplicity and reflective nature and foreshadows the use of repetition in upcoming songs. 


\section{Aus meinen Tränen sprießen}

Aus meinen Tränen sprießen viel blühende Blumen hervor, und meine Seufzer warden ein Nachtigallenchor.

Und wenn du mich lieb hast, Kindchen, schenk' ich dir die Blumen all', und vor deinem Fenster soll klingen das Lied der Nachtigall.
My tears will make Many flowers bloom, And my sighs will become A choir of nightingales.

And if you love me, little one, I'll give you all the flowers, And the song of the nightingale Will sound outside your window. ${ }^{52}$

Key: A major

Form: Modified miniature ternary

Accompanying Style: Homophonic and chorale-like

Predominant Characteristics of Vocal Line: Repeated notes, narrow range

The second poem represents a man who is sentimental and fondly and tenderly obsessed with his beloved. In the poem, Heine adopts metaphorical speech describing the poet's tears making the flowers bloom and his sighs becoming a choir of nightingales, all of these to obtain her love. Schumann ends on a dominant seventh in the postlude of the first song in the key of Fsharp minor, which is an inconclusive ending. However, he immediately resolves this chord on A major, as the first chord of this second song, but in a higher register on the piano. Schumann straightforwardly expresses the emotion of the poetry here by using a homophonic approach, beginning in the opening bars without a piano introduction. In a modified miniature ABA form, Schumann uses repeated notes, simple harmonies, and a narrow range in the vocal line. The light portato chords in the accompaniment depict the tear drops and the harmony of the nightingales.

52 Glass, Beaumont, Schumann's complete song texts. (Genesco, NY: Leyerle Publications, 2002). 63. 
The whole song is marked "Nicht schnell" (not fast) which represents the somewhat solemn mood, and a repetitive $\mathrm{C} \#$ in the beginning of the vocal line indicates the stillness of the poet's emotions (see Figure 5-5):

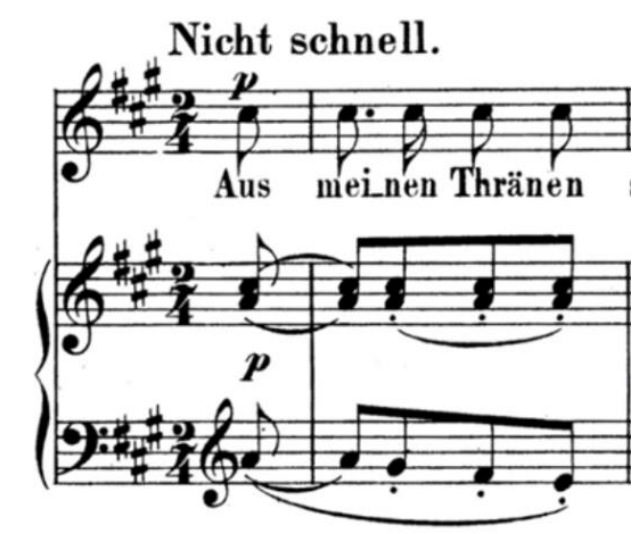

Figure 5-5. Schumann: “Aus meinen Tränen sprießen,” m. 1

From measures one through eight, two phrases are equally divided into four-measures in each. In measure four, Schumann uses an interesting technique of resolving the vocal line in the piano. The singer holds the note $\mathrm{B}$ of the $\mathrm{V}^{7}$ chord followed by the resolution to the tonic in the piano (see Figure 5-6): 
Nicht schnell.

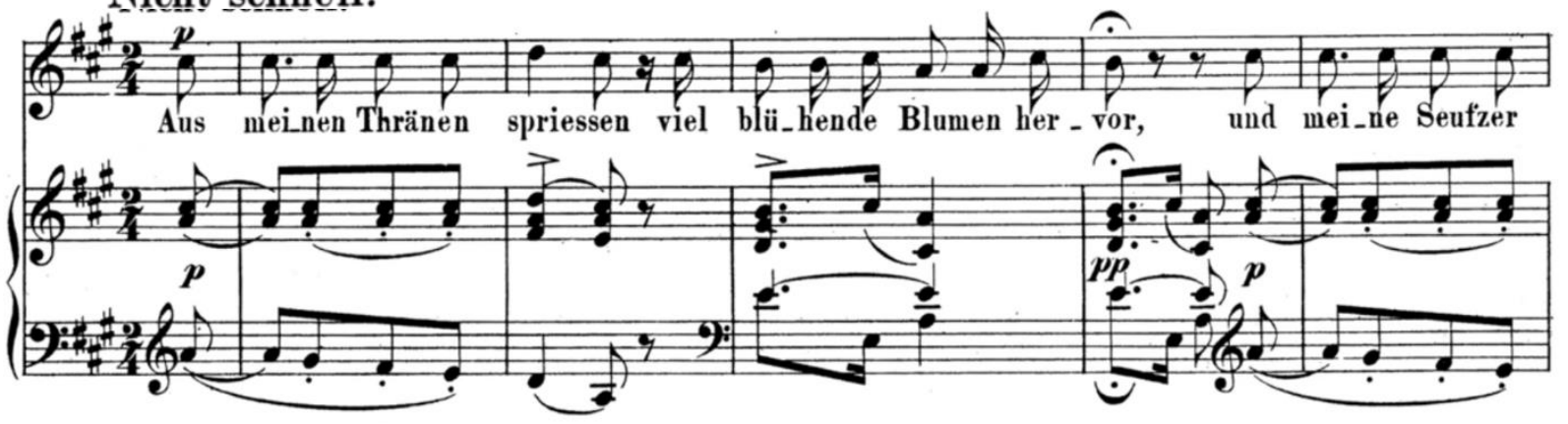

$\begin{array}{llllllll}\text { A: I } & \text { IV } & \text { I } & V^{7} & \text { I } & \text { V }^{7} & \text { I } & \text { I }\end{array}$

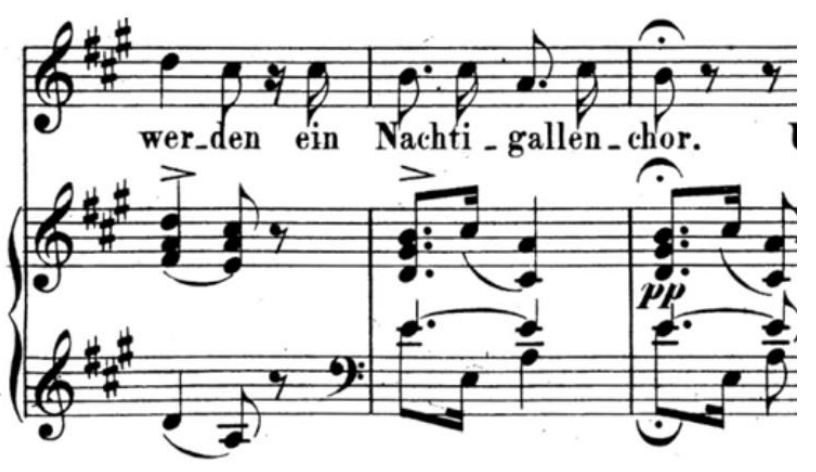
A: IV I
$\begin{array}{llll}\mathrm{V}^{7} & \mathrm{I} & \mathrm{V}^{7} & \mathrm{I}\end{array}$

Figure 5-6. Schumann: "Aus meinen Tränen sprießen,” mm. 1-8

From measures nine through 12 , Schumann begins with a new phrase that continues in the key of A major. Schumann uses a chromatic harmony to emphasize the word "Kindchen" ("little one"), which shows how the poet cares for his beloved with this endearing name. In measure 11, Schumann depicts the words "Blumen all" ("all the flowers") by modulating to Fsharp minor and uses staccato chords, almost as he picks the flowers for her (see Figure 5-7): 


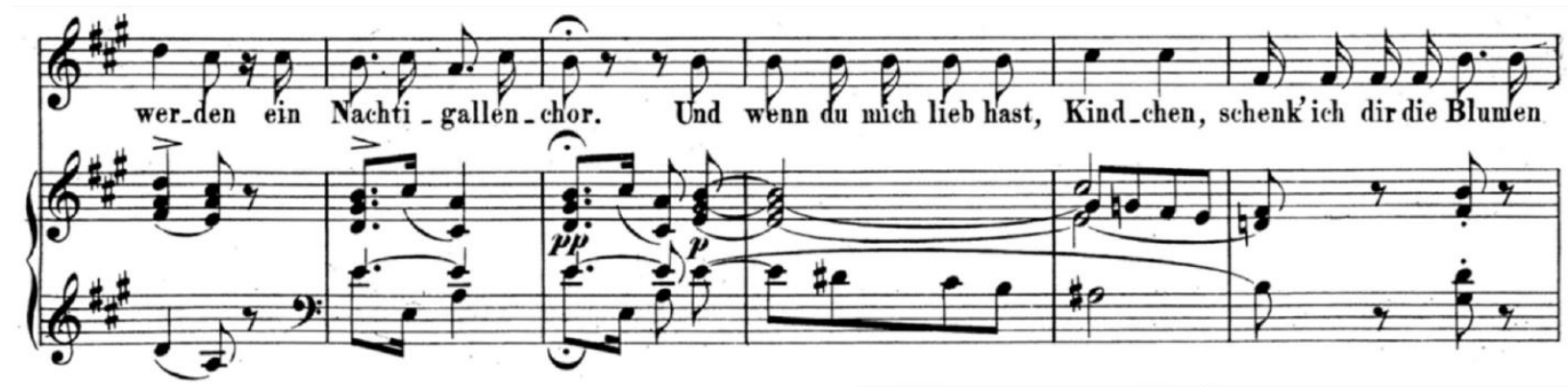

A:

V

$\mathrm{vii}^{\varnothing 7} / \mathrm{ii} \quad$ ii

f\#: iv

ii $\varnothing 7$

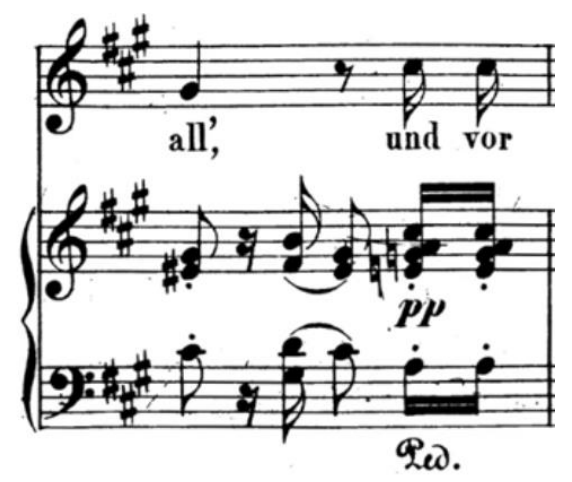

f\#: $\quad \mathrm{V} \quad \mathrm{ii}^{\varnothing 7} \mathrm{~V}$

Figure 5-7. Schumann: “Aus meinen Tränen sprießen,” mm. 6-12

In measure 12, Schumann resolves to $\mathrm{V}$ in F-sharp minor, which is a half cadence, and returns to A major for the end of the song. In the last phrase, the poet wishes to give his beloved the song of the nightingale outside of her window. Therefore, he sincerely wishes her to be happy, not only fulfilling his own desire, but in a sense blessing her. The last note B held in the voice part of measure 16 resolves in the piano as in the previous times. This last B in the vocal line is also resolved vocally in the upbeat A of the third song "Die Rose, die Lilie, die Taube, die Sonne" (see Figure 5-8): 


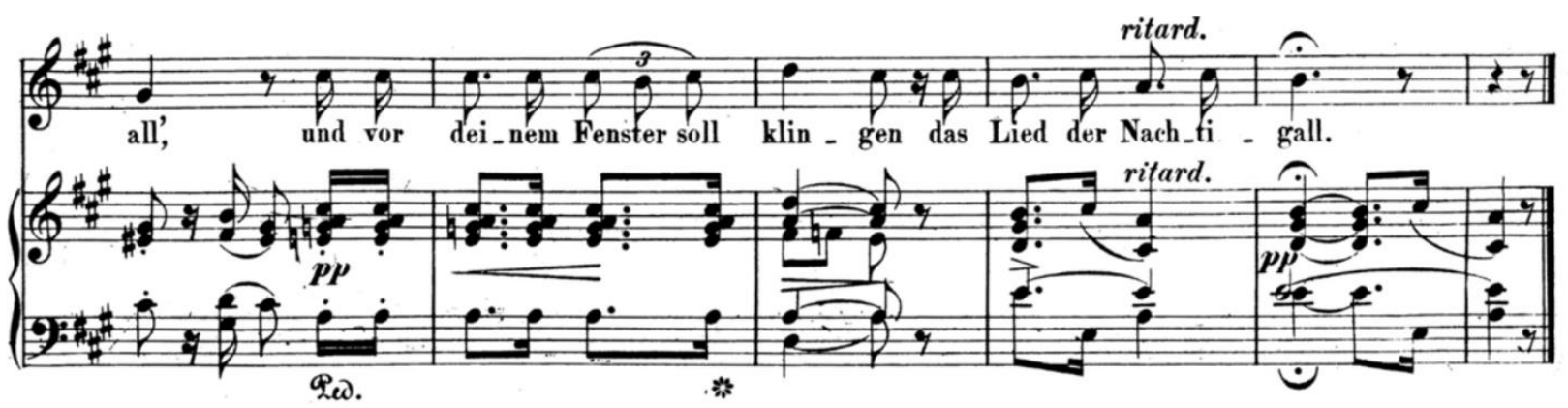

f\#: $\quad \mathrm{V} \quad$ ii $^{\varnothing 7} \mathrm{~V} \quad \mathrm{~V} 7 / \mathrm{VI}$
A: $V^{7} / I V$
IV I
$\mathrm{V}^{7} \quad \mathrm{I}$
$\mathrm{V}^{7}$
I

Figure 5-8. Schumann: “Aus meinen Tränen sprießen,” mm. 12-17

"Aus meinen Tränen sprießen" is a brief song that quietly continues the unsettled longing of the poet. Schuman again makes much use of repetition throughout the song. Moreover, the interaction of the voice and the piano is intriguing. Schumann adds a pedal indication in measure 12, to hold the damper pedal until measure 14. The pedal should have been used lightly until this bar, which should vibrate with a fullness of emotion. ${ }^{53}$ Schumann leaves the incomplete, unresolved note B in the vocal line to create an unsettling effect three times. The unstable emotion does not last, however, as the piano always resolves to the tonic in the next measure. The conversation between the voice and the piano is a fascinating factor in Schumann's writing overall, and it represents a dependent relationship, with the vocal line normally responsible for the melody, but the piano equally interesting and intertwined with the voice as it provides the harmony and text painting.

\footnotetext{
${ }_{53}$ Rosen, Charles, "Fragments," in The Romantic Generation. (Cambridge, Massachusetts: First Harvard University Press, 1998), 54.
} 


\section{Die Rose, die Lilie, die Taube, die Sonne}

Die Rose, die Lilie, die Taube, die Sonne, die liebt' ich einst alle in Liebeswonne, ich lieb' sie nicht mehr, ich liebe alleine die Kleine, die Feine,

die Reine, die Eine;

sie selber, aller Liebe Wonne, ist Rose und Lilie und Taube und Sonne, ich liebe allei die Kleine, die Feine, die Reine, die Eine, die Eine!
The rose, the lily, the dove, the sun, I once loved them all in love's rapture, I don't love them anymore, I only love The little one, the delicate one, The pure one, the only one;

She herself, all of love's rapture, Is rose and lily and dove and sun, I only love the little one, The delicate one, the pure one, The only one, the only one $!^{54}$

Key: D major

Form: Through composed

Accompanying Style: Alternating hands, chordal

Predominant Characteristics of Vocal Line: Rapid syllabic (patter), narrow range

For “Die Rose, die Lilie, die Taube, die Sonne," Schumann uses a through-composed form. He changes the mood from the previous two songs, becoming exceptionally lively. Schumann adopts a patter song style of writing to depict the heightened excitement and whimsical rhyming poetic language. He uses a rapid tempo and interlaced piano and vocal lines that result in a song shrouded by breathlessness without respite.

The A major chord in the piano at the end of the previous song acts as the dominant for this song in D Major. The first four bars depict the poet's admiration and fondness for nature, and the four bars after represent the poet's infatuation with his beloved, even though the music is almost identical. Schumann utilizes D-C\#-B as a repetitive motive. Harmonically, in measure

\footnotetext{
${ }^{54}$ Glass, Beaumont, Schumann's complete song texts. (Genesco, NY: Leyerle Publications, 2002). 63-4.
} 
four, Schumann highlights the word "Liebeswonne," which means "love's rapture," by using a chromatic harmony (see Figure 5-9):
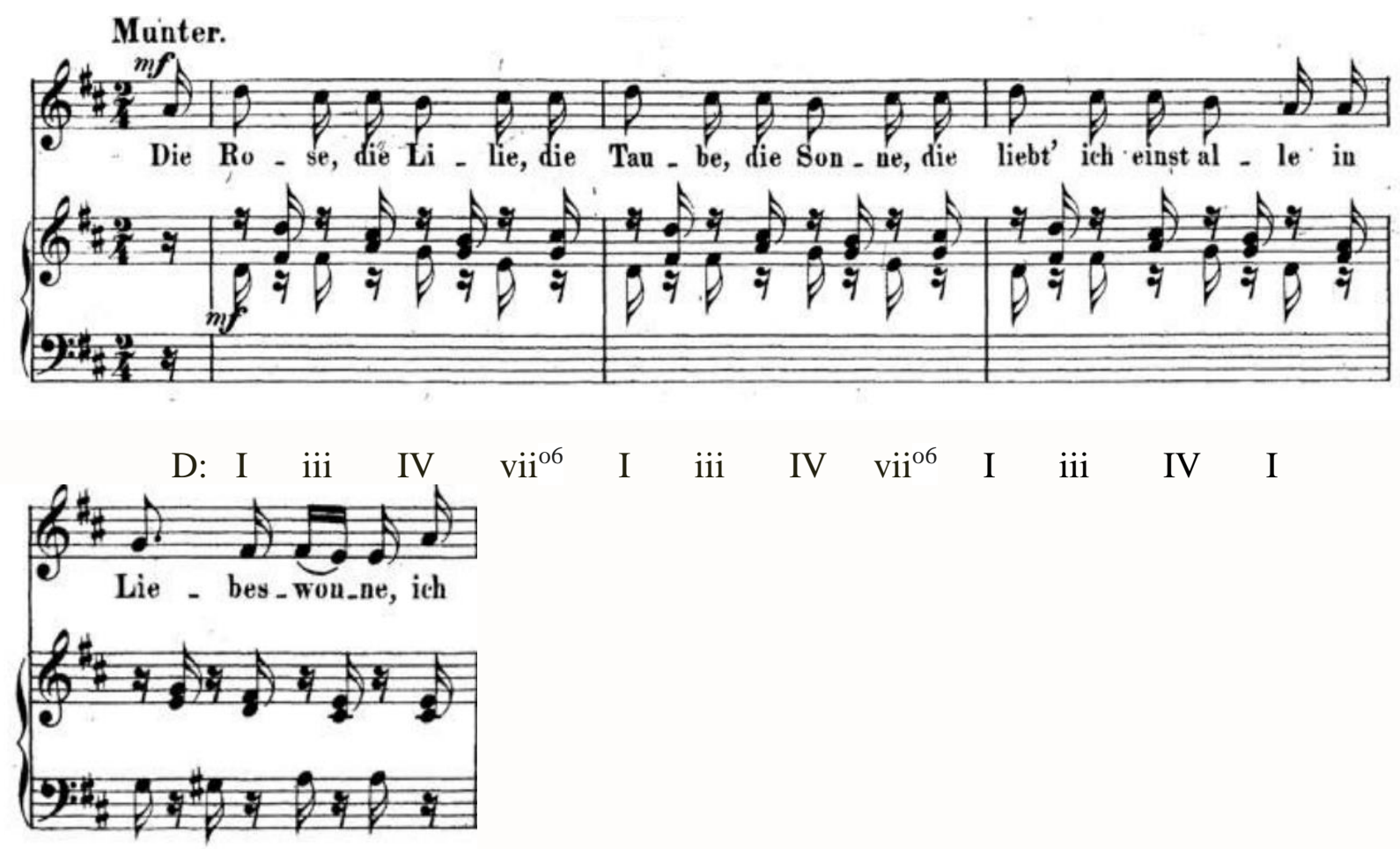

D: $\quad$ ii $^{6} \quad \mathrm{vii}^{\phi 7} / \mathrm{V} \mathrm{V} \quad \mathrm{V}$

Figure 5-9. Schumann: "Die Rose, die Lilie, die Taube, die Sonne," mm. 1-4

In measure five with "ich lieb' sie nicht mehr," ("I don't love them anymore,") the poet suddenly rejects all these, as the beauty of nature no longer impresses him. Schumann represents the disparate objects of the poet's love by using a repeated musical phrase. Therefore, musically, this passage is a challenge for two musicians to distinguish between the two brief phrases and their meanings (see Figures 5-9 and 5-10): 


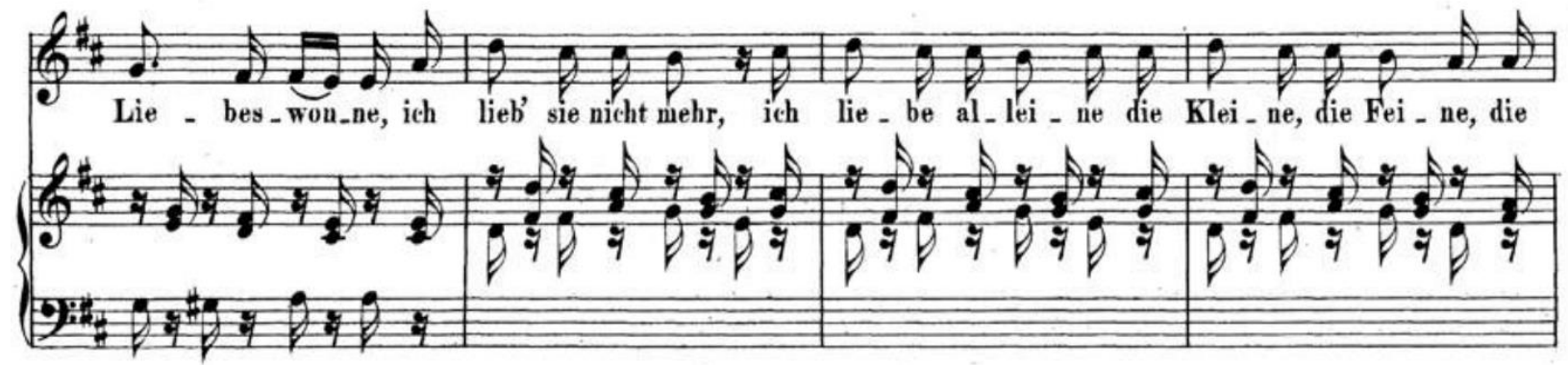

D: I iii IV vii ${ }^{06}$ I iii IV vii ${ }^{06}$ I iii IV I

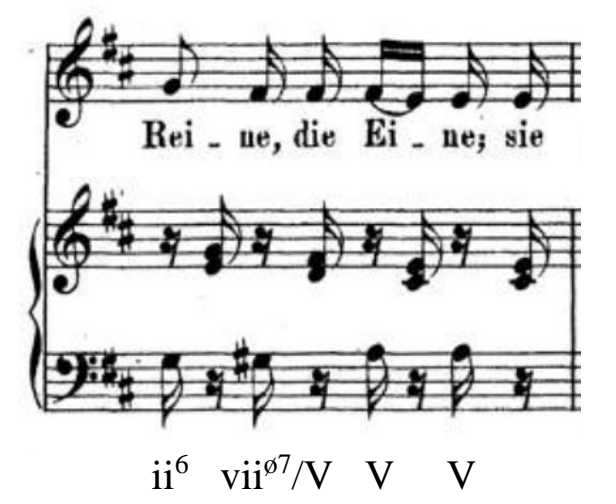

Figure 5-10. Schumann: "Die Rose, die Lilie, die Taube, die Sonne,” mm. 4-8

The most dramatic moment in the song is in measures nine through 12. Schumann takes advantage of chromatic chords to intensify the color of the music and indicate the poet's praise of his beloved. Schumann's expression with the ritard in measures 11 and 16 emphasizes “ich liebe allei die Kleine" ("I only love the little one") and "die Eine" ("the only one"). Schumann not only uses a ritard as an expressive approach, but also creates a legato gesture for the left hand in mm. 10 and 11 in order to heighten the expression (see Figure 5-11 and 5-12): 


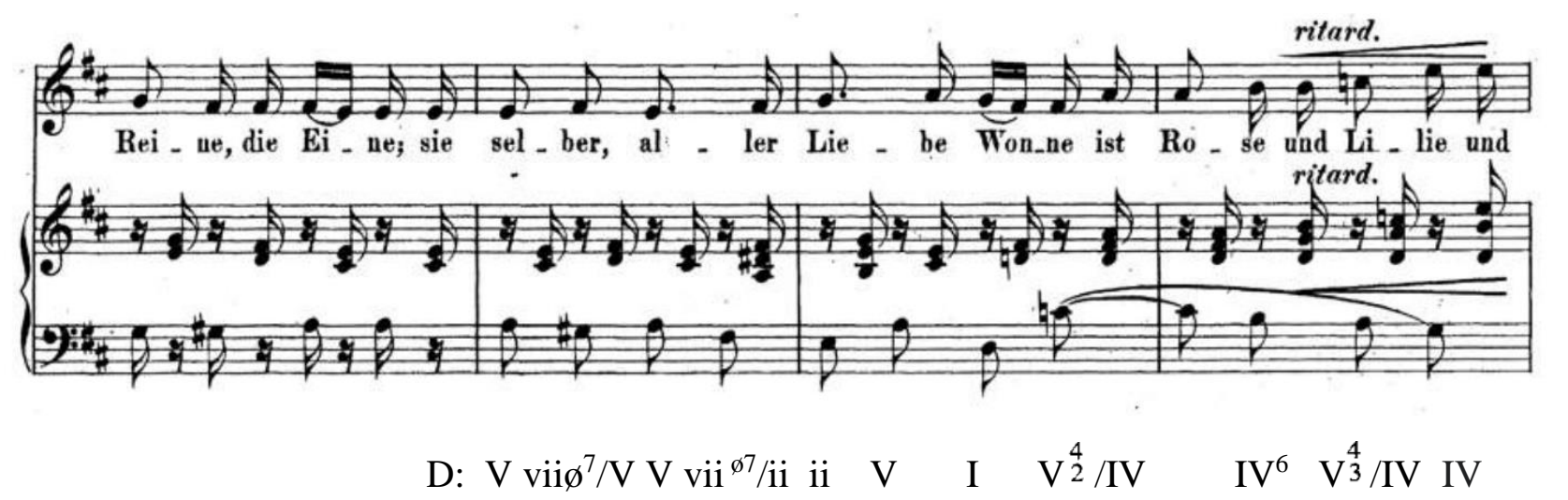

Figure 5-11. Schumann: "Die Rose, die Lilie, die Taube, die Sonne," mm. 8-11

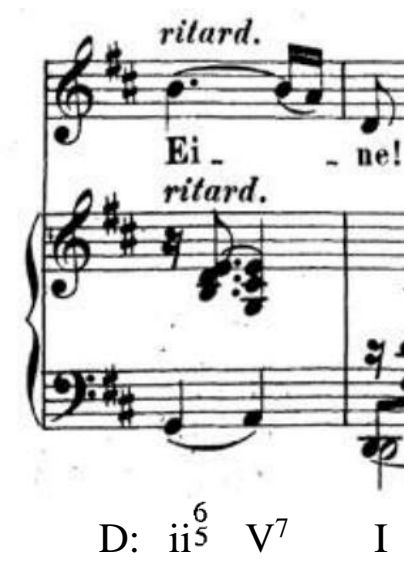

Figure 5-12. Schumann: "Die Rose, die Lilie, die Taube, die Sonne," mm. 16-17

Schumann uses a six-measure postlude after the last “die Eine!” (“only you!") The right hand is played using a vigorous portato, while the left hand features a D pedal tone and a layered legato ascending pattern. Schumann continues to hold the expression in the postlude by keeping the left-hand beat and right hand off-beat chords in strict rhythm, as if to say: my love for you will never be shaken. Then the last two staccato chords confirm his determination (see Figure 5$13)$ : 


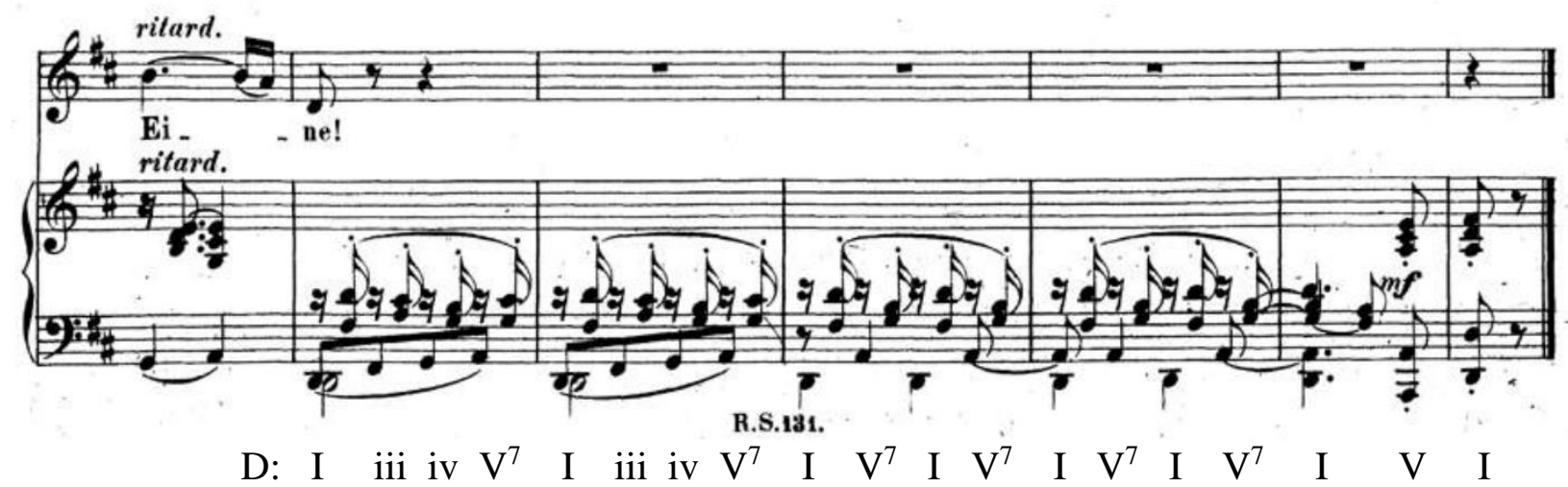

Figure 5-13. Schumann: “Die Rose, die Lilie, dirapie Taube, die Sonne,” mm. 17-22

The perpetual accompaniment figure, interlaced rhythms, and excited character in "Die Rose, die Lilie, die Taube, die Sonne" present a change of mood for the start of the cycle. The lightly supportive music, a rapid iteration of words, and a fast-proceeding rhythm are the features of the patter song, which exist in Haydn, Mozart, and Rossini operas. ${ }^{55}$ Vocally, the singing style is more like Italian opera, such as Figaro's aria "Largo al Factotum” in Rossini's The Barber of Seville (1813), ${ }^{56}$ and the vocal line is virtually without rests, except the short rest in measure five. Coordinating the brief time for the singer to quickly breathe can be challenging. Schumann uses no introduction here again, but the postlude requires the pianist to maintain a steady left-hand rhythm to heighten the off-beat chords and continue the mood.

\footnotetext{
${ }^{55}$ Craig, David, "Patter Song," in A Performer Prepares: A Guide to Song Preparation for Actors, Singers and Dances. (New York: Applause, 1993), 212.

${ }^{56}$ Brody, Elaine and Robert A. Fowkes, "The New Style of Piano Accompaniments," in The German Lied and Its Poetry. (New York: New York University Press, 1971), 120.
} 


\section{Wenn ich in deine Augen seh'}

Wenn ich in deine Augen seh', so schwindet all' mein Leid und Weh. doch wenn ich küsse deinen Mund, so werd' ich granz und gar gesund.

Wenn ich mich lehn' an eine Brust, kommt's über mich wie Himmelslust; doch wenn du sprichst: Ich liebe dich, so muss ich weinen bitterlich.
When I look into your eyes, Then all my sorrow and pain disappears; But when I kiss your mouth Then I am completely, fully healed.

When I lean against your breast, Heavenly pleasure comes over me; But when you say: I love you, Then I start to weep bitterly. ${ }^{57}$

Key: G major

Form: Through-composed

Accompanying Style: Homophonic and chorale-like

Predominant Characteristics of Vocal Line: Repeated notes

"Wenn ich in deine Augen seh" is a declaration of love, conveying the emotions of soulfulness and melancholy. The poet reflects on the heartfelt closeness with the beloved, and the words initially suggest a soothing, comfortable love. However, the poem takes an important turn at the end to express the bitterness of irony. Schumann uses the compositional techniques of imitation and parallel writing between the voice and piano for depicting the love between the poet and the beloved.

Schumann took advantage of a through-composed form to build the structure of the song, and he uses repetition in the main motive with the piano echoing the voice. In the beginning, the slow repeated notes in the vocal line illustrate the intimacy and inner feeling of the poet, the same feature as in the second song "Aus meinen Tränen sprießen.” (see Figure 5-14):

${ }^{57}$ Glass, Beaumont, Schumann's complete song texts. (Genesco, NY: Leyerle Publications, 2002). 64. 


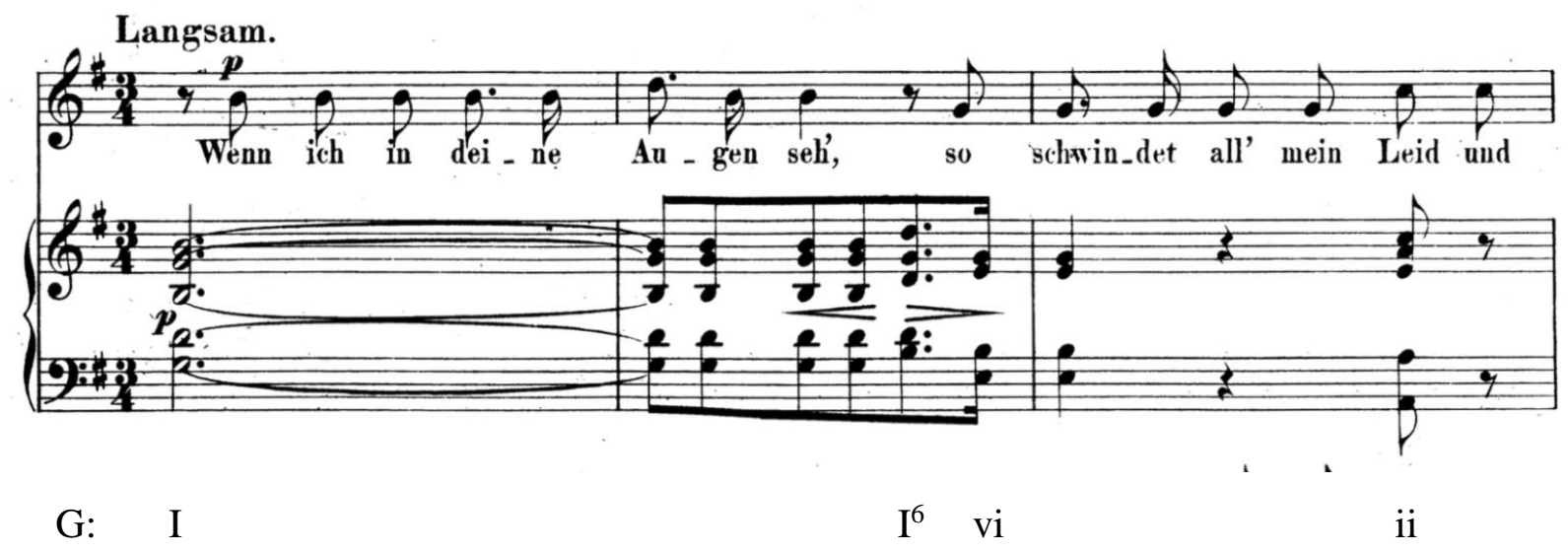

Figure 5-14. Schumann: "Wenn ich in deine Augen seh"," mm. 1-3

The chromatic tones break the former tranquility in measure five through seven. G major is the tonality of the song, but Schumann uses two modulations. He first modulates to the key of $\mathrm{C}$ in measure four through a pivot A minor chord, then Schumann achieves the thrilling moment with the word "Mund" ("Mouth") by adopting a secondary dominant as a preparation (see Figure 5-15):

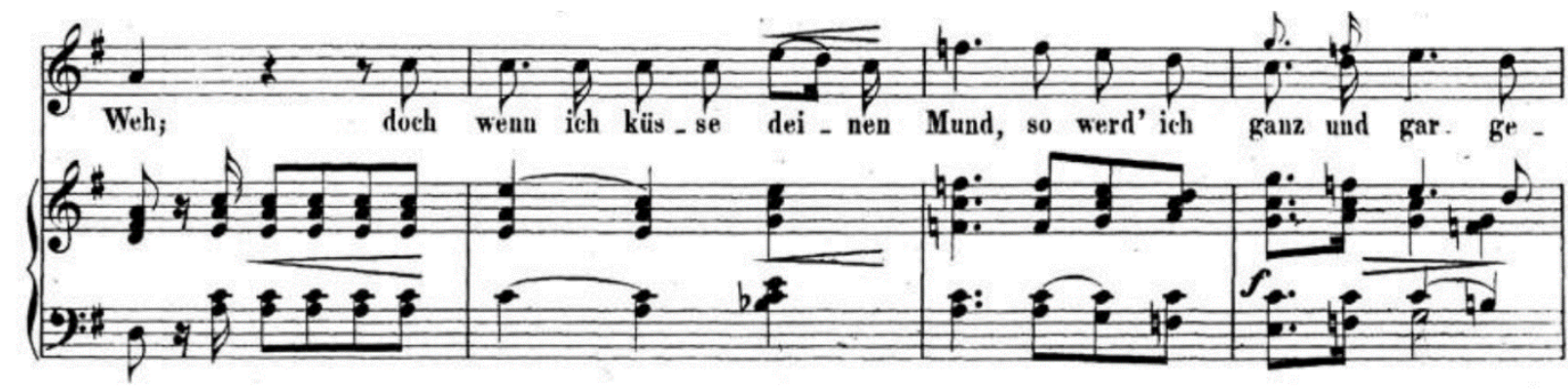

G: $V$ ii
C: vi
$\mathrm{vi}^{6} \quad \mathrm{vi} \quad \mathrm{V}^{\frac{4}{2}} / \mathrm{IV}$
$\begin{array}{lllllll}\mathrm{IV}^{6} & \mathrm{I}^{6} & \mathrm{ii}^{6} & \mathrm{I}^{6} & \mathrm{IV} & \mathrm{I}^{6} & \mathrm{~V}^{7}\end{array}$

Figure 5-15. Schumann: "Wenn ich in deine Augen seh'," mm. 4-7 
In the second stanza, Heine's yearning for his loved one grows increasingly intense. After the first modulation to the subdominant, Schumann depicts the scene using a second modulation to the melancholy atmosphere of E minor. The piano leads here with the voice responding.

Schumann retains the repeated notes in the inner voices and adds an upper motive in the piano accompaniment (see Figure 5-16):

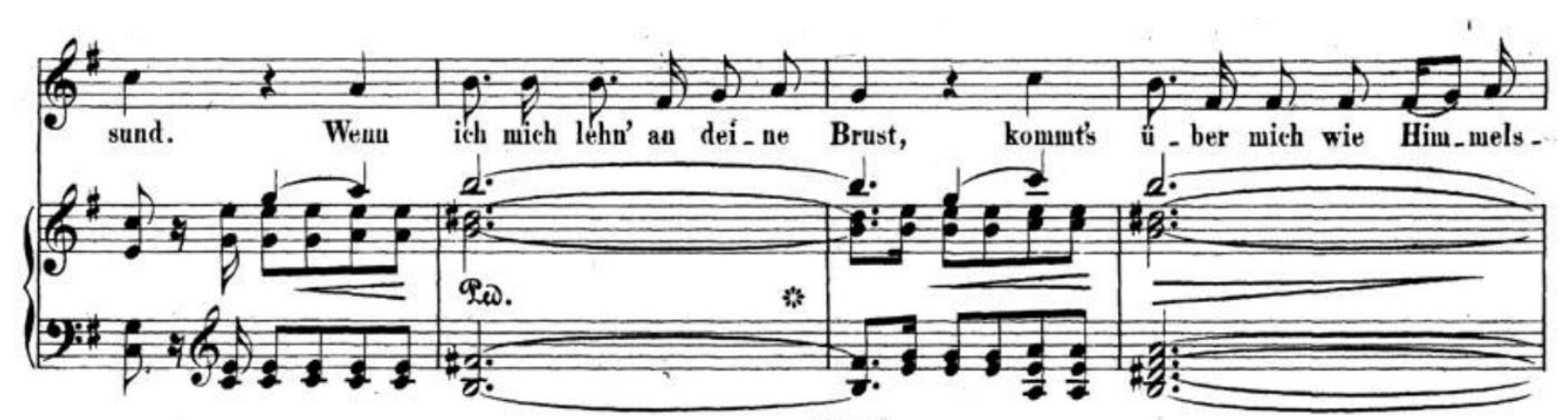

C: $\mathrm{I} \quad \mathrm{vi}^{6}$

e: iv $\mathrm{V}^{7} \quad$ i $\quad$ iv $\mathrm{V}^{7}$

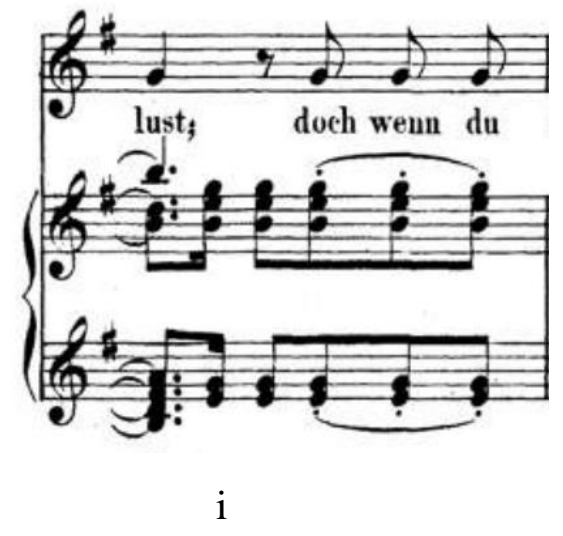

Figure 5-16. Schumann: "Wenn ich in deine Augen seh,," mm. 8-12

In an ingenious depiction, Schumann uses a harsh and uneasy chromatic harmony on the downbeat of measure 13 on the word "sprichst" of "doch wenn du sprichst:" ("but when you say:"). He emphasizes and prolongs the word with a downward eighth-note arpeggio under a 
ritard which represents the most painful moment of the whole song. Schumann then resolves to the A minor chord in the next measure when she says "Ich liebe dich" ("I love you"). However, the most expressive moment happens on the word "liebe" with the note B, an appoggiatura, as the pain becomes tenderness (see Figure 5-17):

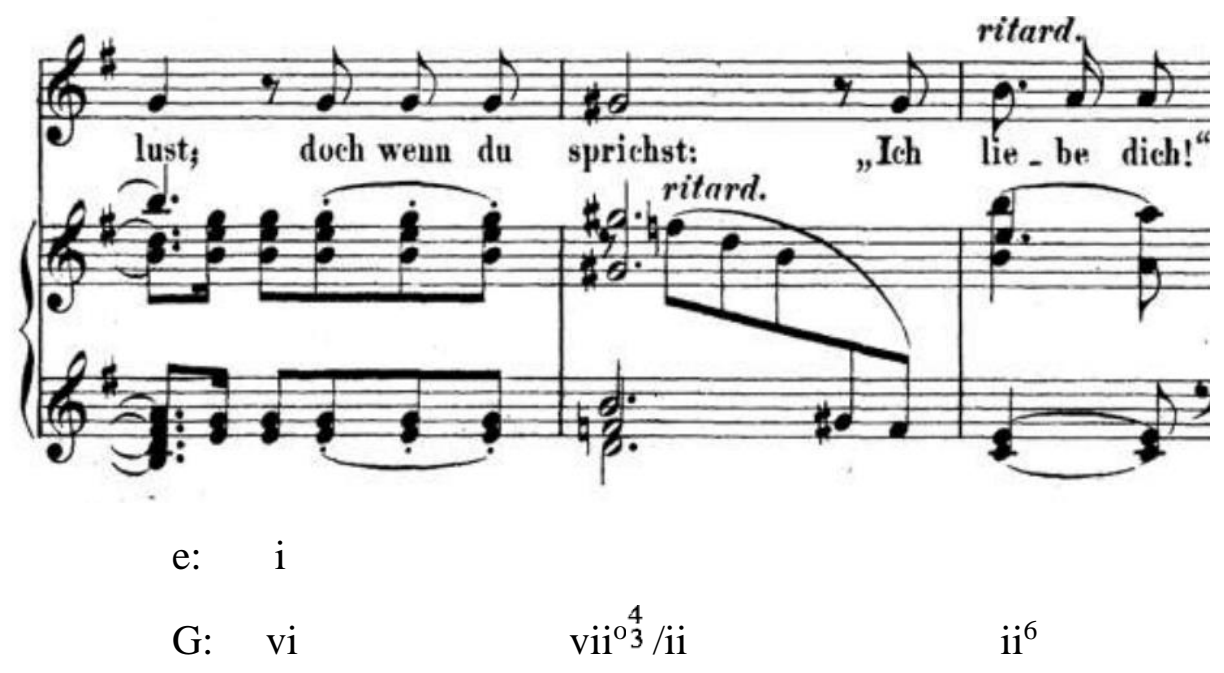

Figure 5-17. Schumann: "Wenn ich in deine Augen seh'," mm. 12-14

After the last line of the poem, Schumann was not satisfied with the song hastily finishing. He adds, for the poet's inner voice, a piano postlude. The postlude depicts the tears that the poet bitterly wept and a gradual vanishing based on the downward register changes. Schumann divided the postlude into three short 2-measure passages. In the first and second passages, Schumann applies portato for both hands, imitating the tear drops. In measures 17 and 19, two beautiful moments occur when the struck suspension happens on the downbeat note D. In the last two bars, Schumann uses the lowest register of the three passages, which represents the poet's descent in mood (see Figure 5-18): 

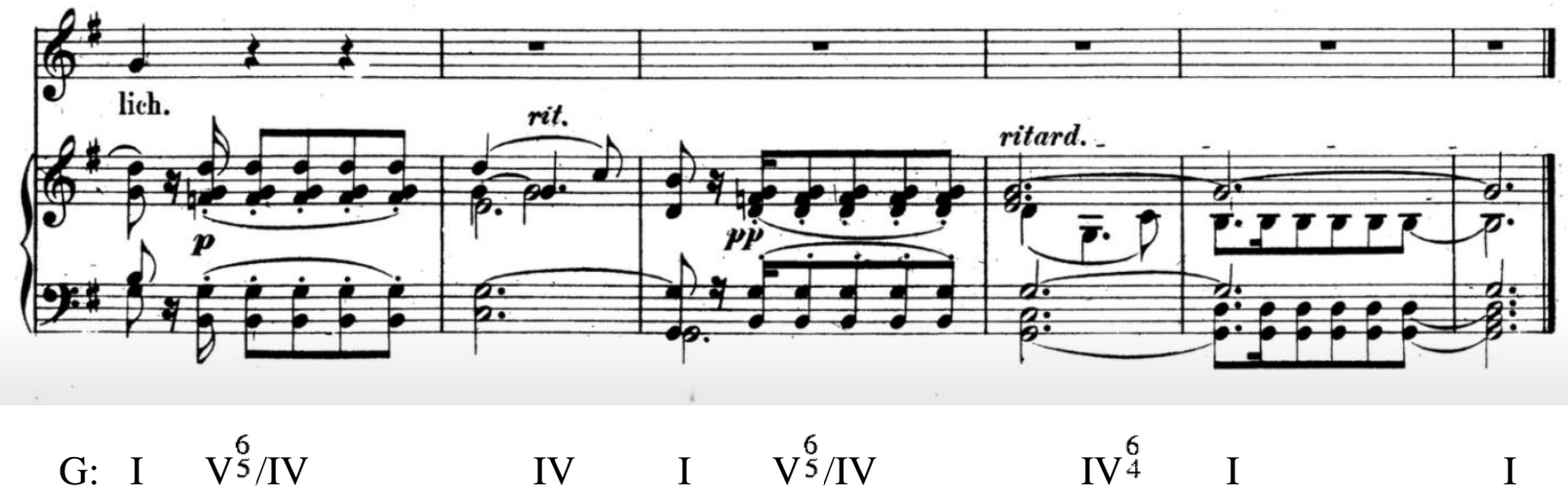

Figure 5-18. Schumann: "Wenn ich in deine Augen seh'," mm. 16-21

Musically, echoing and doubling are the two prominent features between the piano and voice. The interaction of the two parts represents the interaction of the poet and the beloved. Schumann again uses repeated notes in the vocal line, chorale-like piano writing and effective chromatic harmonies to highlight the intimate and ultimately painful nature of the poem. "In Schumann for the first time a single chord can be an event". ${ }^{58}$ The chord in measure 14 has a significant impact on the song and is a good example of this statement.

\footnotetext{
${ }^{58}$ Swafford, Jan, "The Romantic Period," in The Vintage Guide to Classical Music. (New York: Vintage Books, 1992). 242.
} 


\section{Ich will meine Seele tauchen}

Ich will meine Seele tauchen in den Kelch der Lilie hinein, die Lilie soll klingend haubchen ein Lied von der Liebsten mein.

Das Lied soll schauern und beben wie dier Kuss von ihrem Mund', den sie mir einst gegeben in wunderbar süsser Stund'!
I want to plunge my soul Into the chalice of the lily, The lily shall breathe out

The sound of a song about my darling.

The song shall quiver and tremble Like the kiss from her mouth, That she once gave me In a wondrously sweet hour! ${ }^{59}$

Key: B minor

Form: Modified strophic

Accompanying Style: Rapid thirty-second note arpeggios, layered writing

Predominant Characteristics of Vocal Line: Narrow range, stepwise

In "Ich will meine Seele tauchen," Heine uses religious language to speak of his longing. The "chalice of the lily" represents the cup of Holy Communion" 60 and becomes a metaphor for the poet's exalted love. Schumann uses Leise as an expressive tempo marking, which means quiet. Leise symbolizes the poet's romantic mood, which is a private emotional catharsis, not a public outpouring.

In the vocal line, the upbeat B begins the song with no piano introduction (see Figure 5-

19):

${ }^{59}$ Glass, Beaumont, Schumann's complete song texts. (Genesco, NY: Leyerle Publications, 2002). 64-5.

60 Historic Trinity, "Emblems And Icons," accessed December 29, 2020, https://www.historictrinity.org/ourhistory/architecture/stained-glass/stained-glass-windows-emblems-and-icons/ 


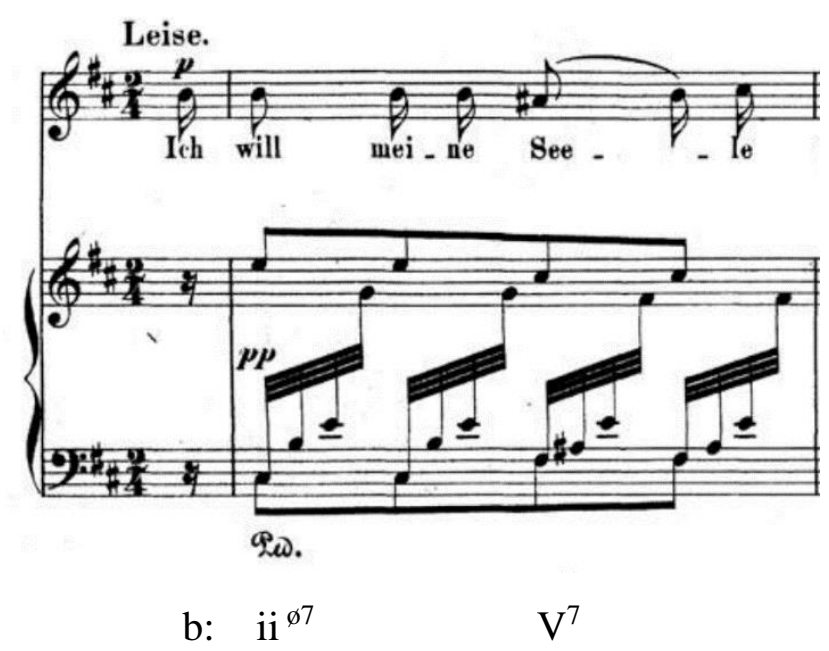

Figure 5-19. Schumann: "Ich will meine Seele tauchen," m. 1

The poem conveys the memory of her kiss compared to a song that "shall quiver and tremble." Schumann uses a light layered arpeggiated accompaniment to depict that quivering, fragile memory. Rhythmically, in the voice part, Schumann adopts a triplet in measure 15 that distinguishes it from measure seven; the purpose is a temporary cushion to highlight the word "wunderbar" (“wondrously”). Harmonically, in measure seven, Schumann uses a secondary leading tone as a transitional chord to the next verse, while in measure 15 , he completed the last word "süsser Stund'!" (“sweet hour”) with $V^{7}$ to I (see Figures 5-20 and 5-21): 


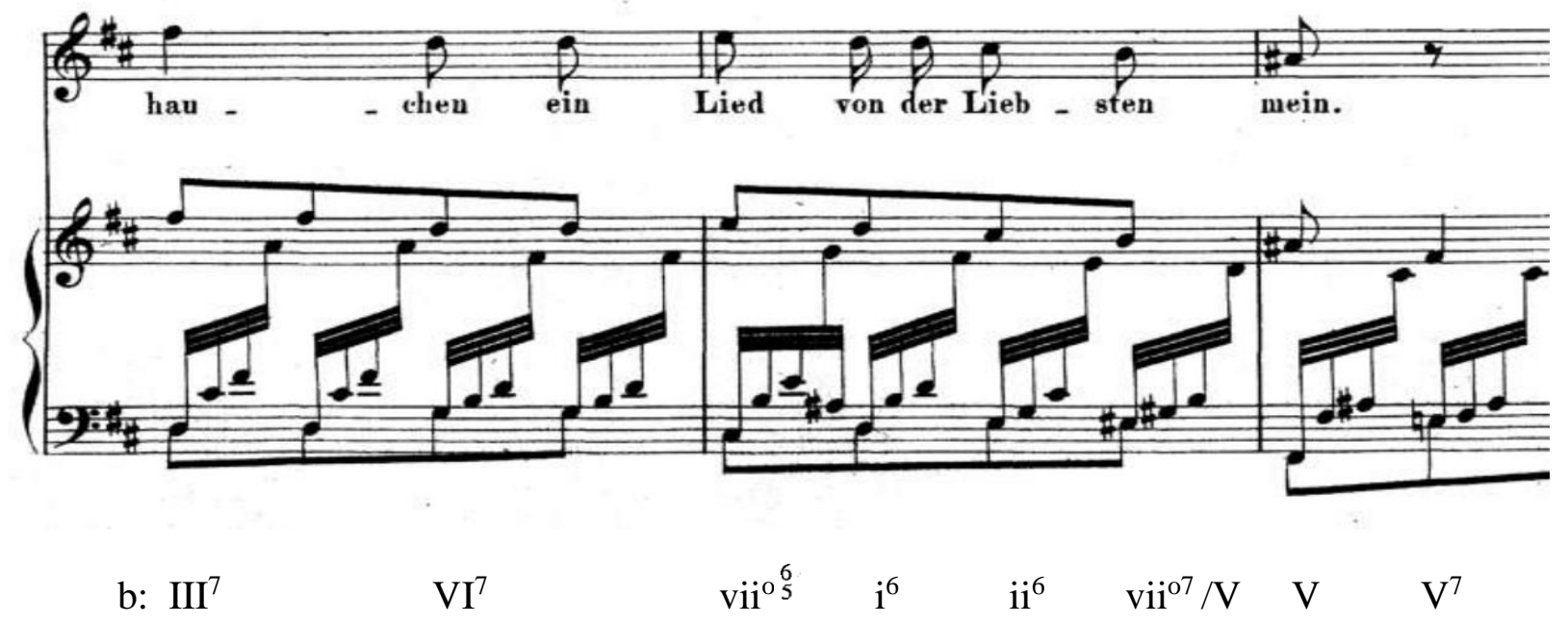

Figure 5-20. Schumann: "Ich will meine Seele tauchen," m. 6-8
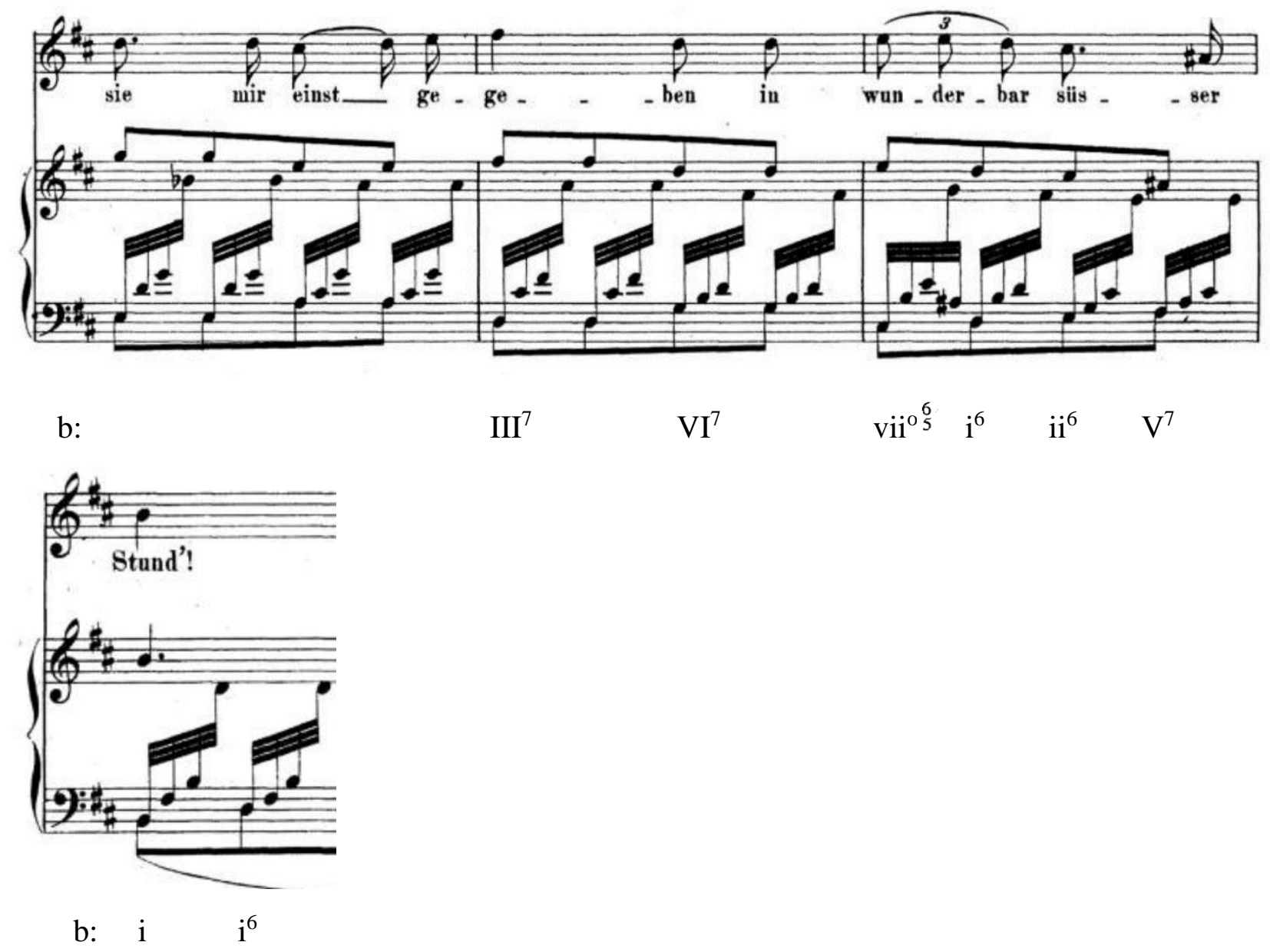

Figure 5-21. Schumann: "Ich will meine Seele tauchen," m. 13-16 
Schumann uses an accompaniment figure throughout that is reminiscent of the Arabeske, Op. $18,{ }^{61}$ that is dividing the inner arpeggiated voice between the two hands, combined with legato eighth-note melodies in the outer voices. This fifth song is Schumann's first use of an extended postlude in Dichterliebe. It acts as a commentary on the fragile emotional state of the poet's love and uses more chromatic harmonies that Schumann resolves using i and iv on every eighth beat in the last three measures (see Figure 5-22):

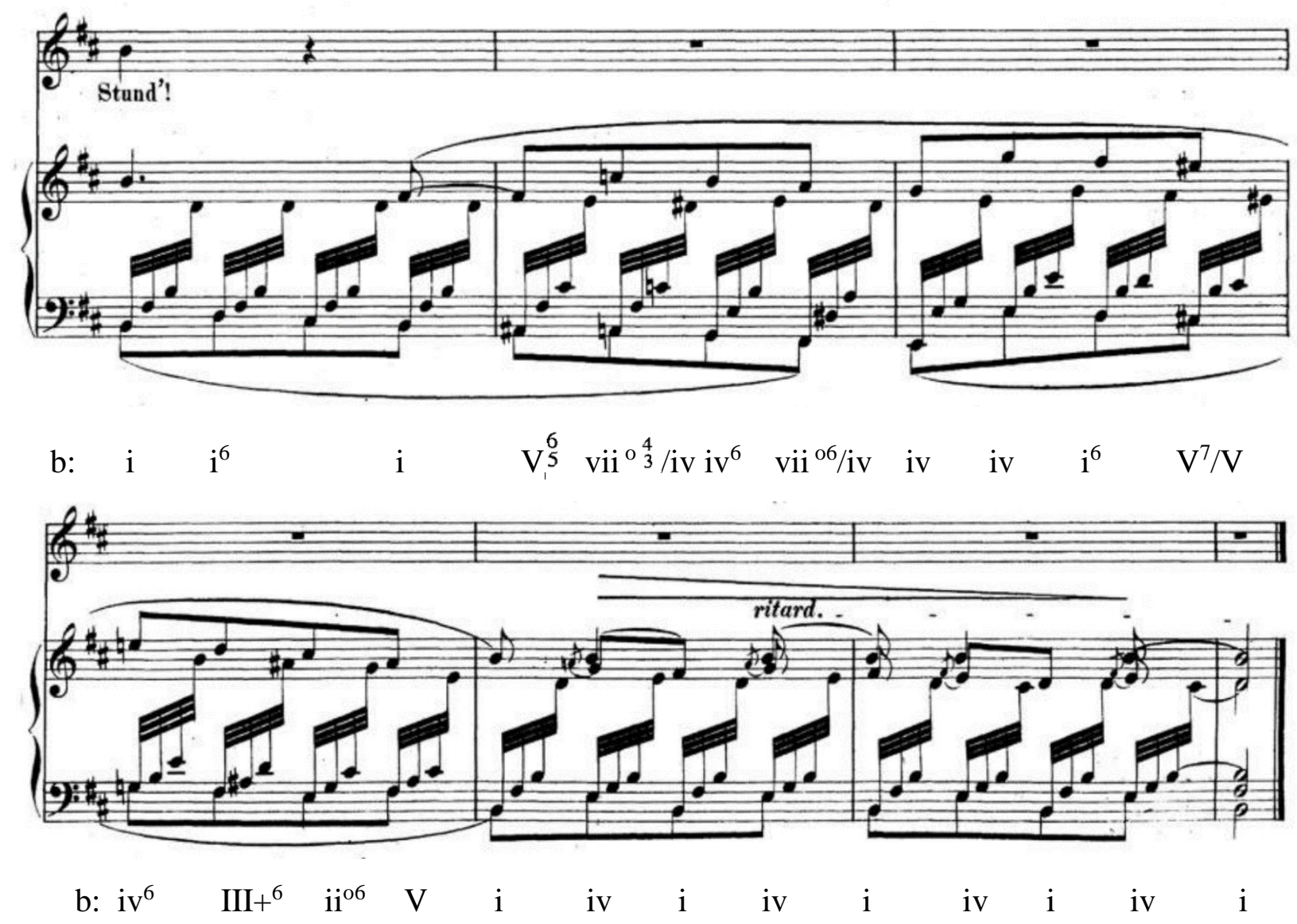

Figure 5-22. Schumann: "Ich will meine Seele tauchen," m. 16-22

\footnotetext{
${ }^{61}$ Brody, Elaine and Robert A. Fowkes, "The New Style of Piano Accompaniments," in The German Lied and Its Poetry. (New York: New York University Press, 1971), 121.
} 
"Ich will meine Seele tauchen" strongly expresses the memory of the beloved's kiss. Schumann applies rapid broken chords in thirty-second notes to symbolize the trembling emotion, the kiss that she once gave him in a wondrously sweet hour. As the tempo indicates Leise in the beginning of the song, for the pianist, the most challenging part of playing this song is to minimize the sound of the accompaniment and highlight the melody within the quiet dynamic range. 


\section{Im Rhein, im heiligen Strome}

Im Rhein, im heiligen Strome, da spiegelt sich in den Well'n, mit seinem grossen Dome

das grosse, heilige Köln.

Im Dom, da steht ein Bildniss auf goldenem Leder gemalt. in meines Lebens Wildniss

hat's freundlich hineingestrahlt.

Es schweben Blumen und Englein Um unsre Liebe Frau, die Augen, die Lippen, die Wänglein, die gleichen der Liebsten genau.
In the Rhine, in the holy river, There is reflected in the waves, The great holy Cologne With its great cathedral.

Inside the cathedral there is an image, Painted on golden leather.

It has radiated a kindly light

Into the wilderness of my life.

Flowers and little angels

Are hovering about Our Lady, Those eyes, those lips, those cheeks, They look exactly like those of my dearest. ${ }^{62}$

Key: E minor

Form: Through-composed

Accompanying Style: Dotted rhythmic pattern

Predominant Characteristics of Vocal Line: Stepwise, use of sequence

In "Im Rhein, im heiligen Strome,” Heine continues using religious imagery. In the great Cologne Cathedral along the Rhine river, the poet sees a glorious painting of the Virgin Mary which he believes that it resembles his beloved. Schumann creates the majestic scene in the key of E minor with Ziemlich langsam (very slow) as the song's pace and a dotted rhythm which is a prominent feature. In addition, the octaves in the left hand also play a solemn role throughout the whole song. The left-hand octaves double the vocal melody in the first seven measures in order to reflect the magnificent cathedral, and the reflection of the Cathedral in the Rhine river. The right-hand dotted figures depict the flow of the river (see Figure 5-23):

62 Glass, Beaumont, Schumann's complete song texts. (Genesco, NY: Leyerle Publications, 2002). 65. 


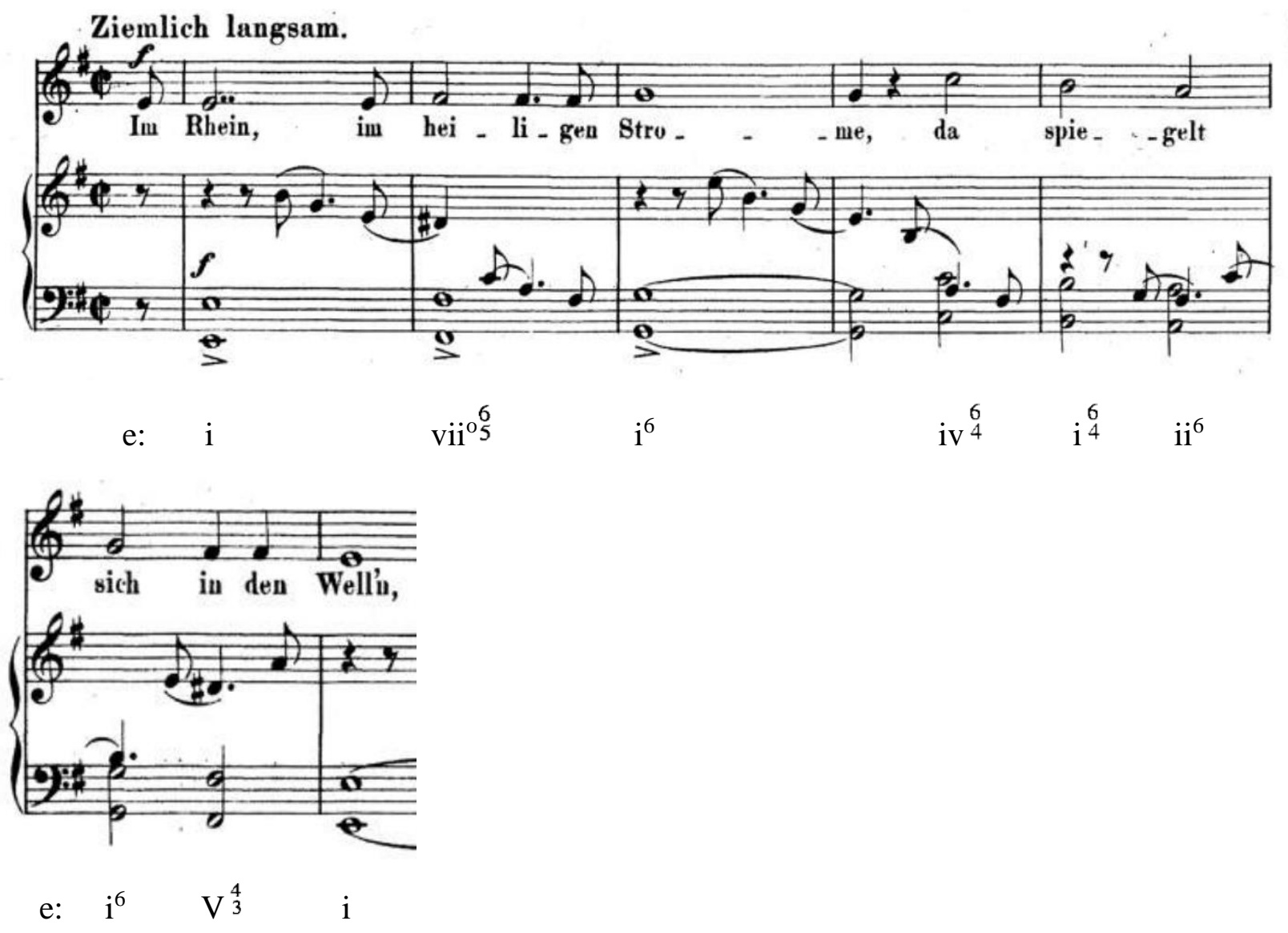

Figure 5-23. Schumann: "Im Rhein, im heiligen Strome," m. 1-7

From measure 17, which is the beginning of the second stanza, the tonality changes from the majestic mood of E minor to a warm-hearted G major. Even the dynamics transfer from intense forte to gentle piano. These mood changes are based on the beautiful image painted on golden leather: Our Lady, the Virgin Mary. In addition, before modulating to G major, the Fnatural and G-sharp in measures 14 and 15 predict a short modulation of A minor until the downbeat of measure 17. During the second section, Schumann still doubles the melody with the octaves, but this time in the right hand (see Figure 5-24): 

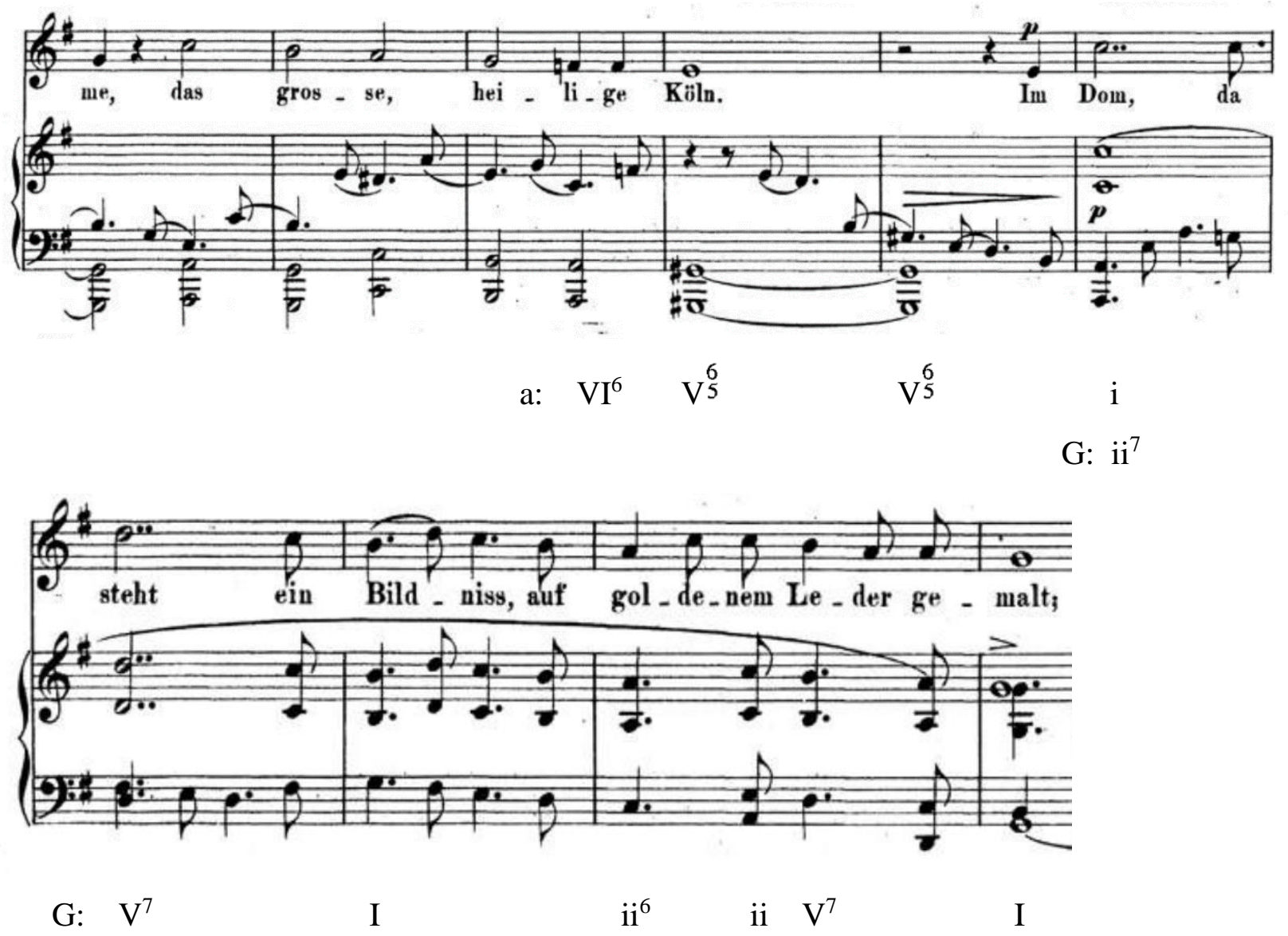

Figure 5-24. Schumann: "Im Rhein, im heiligen Strome,” m. 12-21

The three measures' transition in the piano perhaps acts as a commentary on the previous description of the poet's "Lebens Wildnis" ("wilderness of my life") and consists of diverse and complicated chromatic chords. The chromatic chords happen three times in the first half of the interlude until reaching $\mathrm{C}$ major where the tense atmosphere becomes tender. In addition, Schumann modulates to A minor when the third stanza begins. The modulations happen frequently in this short passage, all of them to closely related keys (see Figure 5-25): 


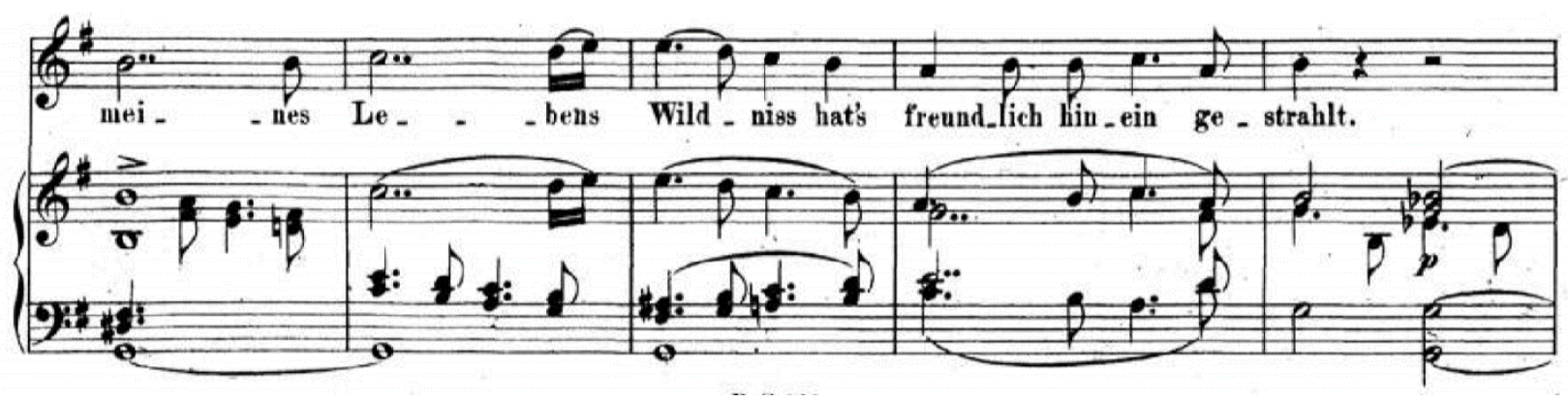

G: bVI

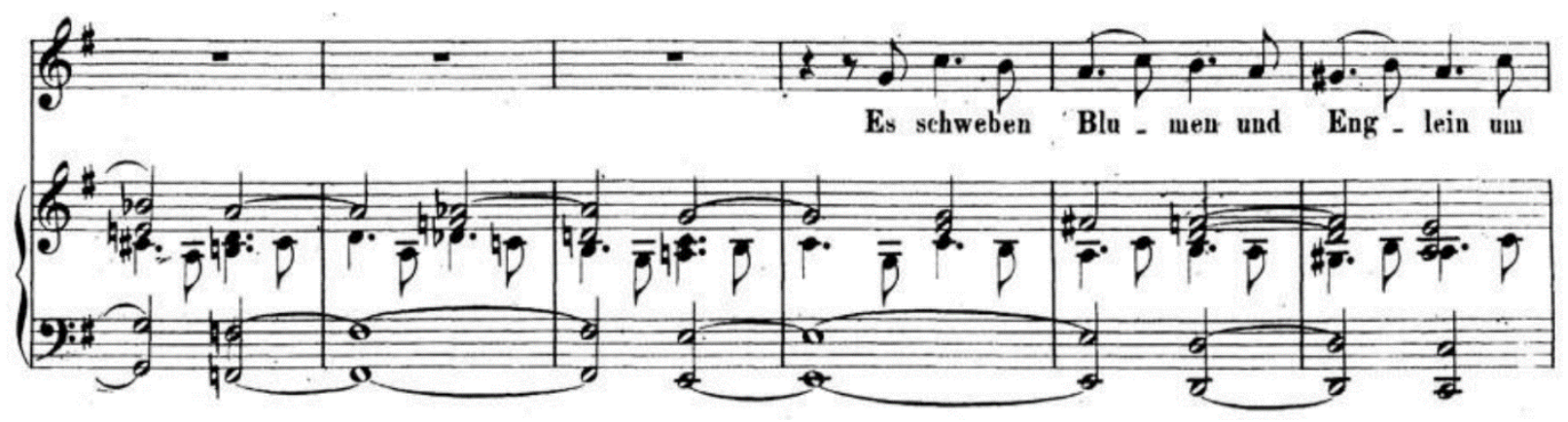

$\mathrm{vii}^{\mathrm{o}_{3}^{4}} / \mathrm{V} \mathrm{vii}^{\phi_{3}^{4}} / \mathrm{iv}$

$\mathrm{C}: \quad \operatorname{vii}^{\phi_{3}^{4}}$ ii $\quad \mathrm{N}^{6} \quad \operatorname{vii}^{\mathrm{O}_{3}^{4}} \mathrm{vi}^{4} \mathrm{I}^{6} \quad \mathrm{vii}^{\mathrm{O}} \frac{4}{2} / \mathrm{V} \quad \mathrm{vii}^{\mathrm{o} 6}$

$\mathrm{a}: \quad \mathrm{ii}^{\mathrm{o} 6} \quad \mathrm{vii}^{\mathrm{O}_{3}^{4}} \quad \mathrm{i}^{6}$

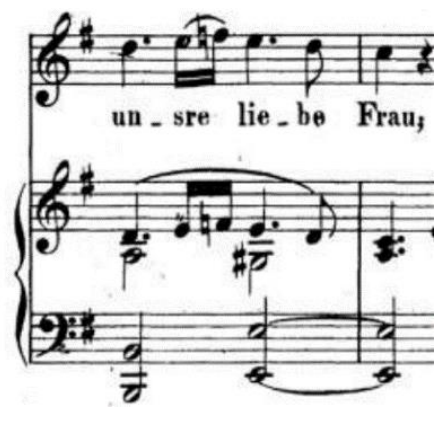

a: ii $^{\varnothing} \quad \mathrm{V} \quad \mathrm{i}$

Figure 5-25. Schumann: “Im Rhein, im heiligen Strome,” m. 23-35

In the third stanza, Heine describes “die Augen, die Lippen, die Wänglein, die gleichen der Liebsten genau" (“the eyes, the lips, the cheeks, they look exactly like those of my dearest.") 
Heine equates the beauty of the Virgin Mary to his beloved. Furthermore, Schumann depicts the intensity here through the pedal tone in the bass and the sequence between measures 36 and 39 . Schumann returns to E minor and uses a poignant French augmented sixth chord on "Liebsten." He ends the vocal part not on the tonic but part of the dominant and uses the descending arpeggio figure in the piano to gradually resolve to the tonic (see Figure 5-26):
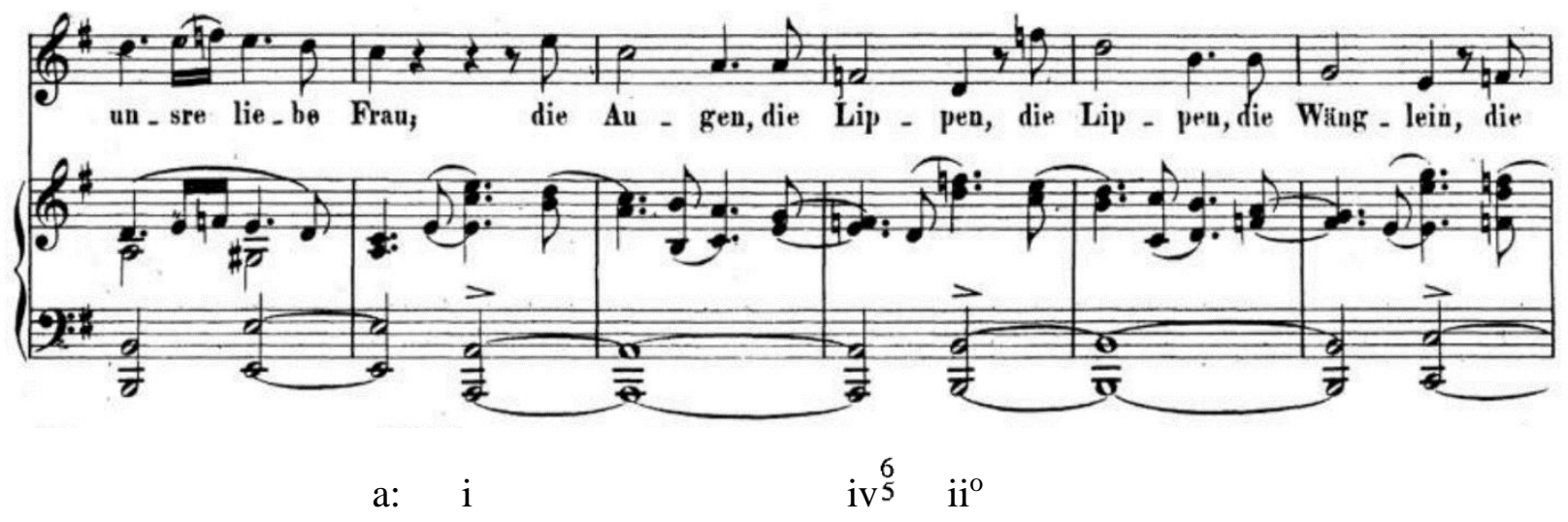
C: vii $^{\circ}$
$V^{6} \quad$ I

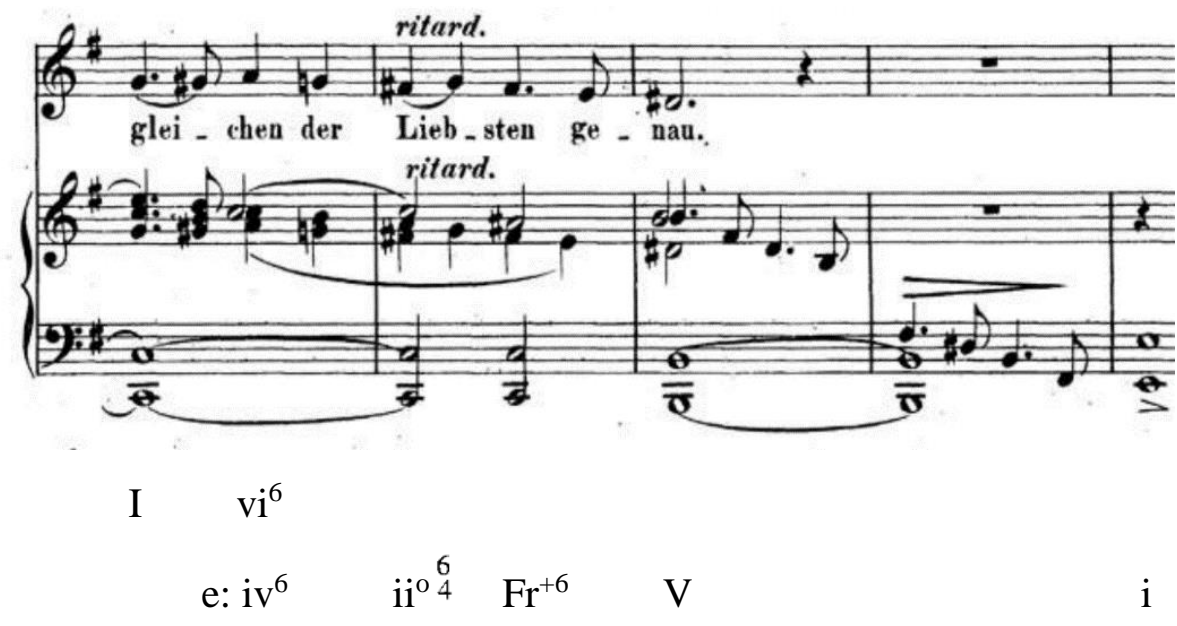

Figure 5-26. Schumann: "Im Rhein, im heiligen Strome," m. 34-44

The extended postlude features the same material as the first six measures in the piano part in order to recall the dignified landscape. Moreover, the harmonies become more dramatic 
and colorful after measure 50, and Schumann expands the passage by using secondary dominant chords three times until reaching the authentic cadence at the end. In addition, the left hand plays a descending diatonic scale in octaves and half notes from measure 47, which starts with $\mathrm{C}$, while the right hand continues the dotted rhythms (see Figure 5-27):
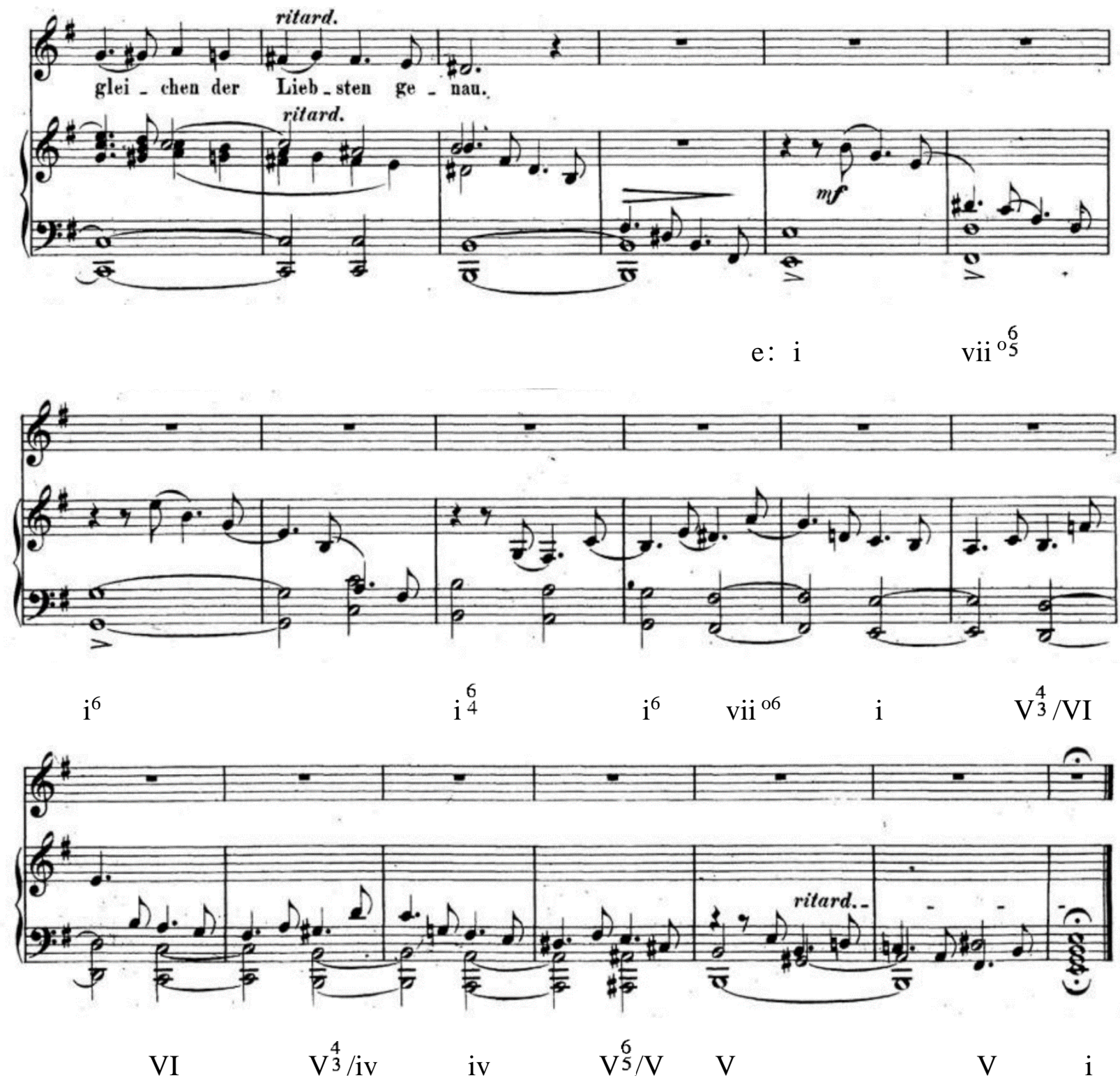

Figure 5-27. Schumann: “Im Rhein, im heiligen Strome,” m. 40-58 
"Im Rhein, im heiligen Strome" is another poem which does not directly address the poet's beloved but represents the idolization of the beloved and an almost sacred love for her. The whole poem is about majesty and solemnity which Schumann emphasizes through powerful octaves and solid dotted rhythms. As in the previous songs, Schumann uses a consistent accompanying style throughout, but as the story unfolds, the piano plays an increasingly larger role in the commentary of the postlude. As a song composer, Schumann followed Schubert and learned from him in many aspects, but he also added new thinking to the Lieder tradition. "He exercised his pianistic imagination to make the accompaniment equal to the voice. With Schubert one remembers the tune; with Schumann one is just apt to remember a piano phrase." 63

\footnotetext{
${ }^{63}$ Swafford, Jan, "The Romantic Period," in The Vintage Guide to Classical Music. (New York: Vintage Books, 1992).
} 243. 


\section{Ich grolle nicht}

Ich grolle nicht, und wenn das Herz auch bricht, ewig verlor'nes Lieb! ich grolle nicht, Ich grolle nicht.

Wie du auch strahlst in Diamantenpracht, es fällt kein Strahl in deines Herzens Nacht, das weiss ich längst.

Ich grolle nicht, und wenn das Herz auch bricht. Ich sah dich ja im Traume, und sah die Nacht in deines Herzens Raume, und sah die Schlang', die dir am Herzen frisst, ich sah, mein Lieb, wie sehr du elend bist. Ich grolle nicht. Ich grolle nicht.
I am not angry, Even though my heart is breaking. Eternally lost love, I am not angry, I am not angry. How you may gleam in the splendor of diamonds, No light ray falls into the darkness of your heart, I have known that for a long time.

I am not angry, Even though my heart is breaking. You know, I saw you in a dream, And saw the darkness in your heart, And saw the snake that is feeding on your heart, I saw, my love, how very wretched you are I am not angry, I am not angry. ${ }^{64}$

Key: C major

Form: Modified strophic

Accompanying Style: Repeated chords

Predominant Characteristics of Vocal Line: Wide range, repeated notes

Unlike the previous two songs, "Ich grolle nicht" ("I am not angry") is directed to the beloved. Heine wrote the poem "Ich grolle nicht" with irony, and he uses the phrase "Ich grolle nicht" twice in total in the poem. ${ }^{65}$ However, Schumann repeats the phrase six times in this song which emphasizes the irony of the bitterness, despair, and heartbreak, even though the poet holds no grudge. Schumann uses repeated chords in the right hand to represent the frustration of the poet as his thoughts consume him. The downbeat accents represent the hardness of his feelings.

\footnotetext{
${ }^{64}$ Glass, Beaumont, Schumann's complete song texts. (Genesco, NY: Leyerle Publications, 2002). 66.

${ }^{65}$ Heinrich Heine: Buch der Lieder, "Heine: Ich grolle nicht," accessed February 03, 2021, https://www.staff.unimainz.de/pommeren/Gedichte/BdL/Lyr-18.html
} 
Moreover, Schumann uses sequence as a compositional technique in order to create the climax of the song.

Schumann uses constant eighth notes in the right hand combined with half-note octaves in the left hand throughout the song. While the left-hand octaves are reminiscent of the previous song, this combination is a new accompaniment style in the cycle. The special moments appear fairly early in the song. In measures three and four, Schumann uses mode mixture ii ${ }^{ø 7}$ and chromatic harmony to depict the words "Herz auch bricht." ("heart is breaking.") In addition, in measures four to seven, the piano plays an octave descending scale in the bass line, while a sequence in bars five to eight occurs when the voice enters (see Figure 5-28):
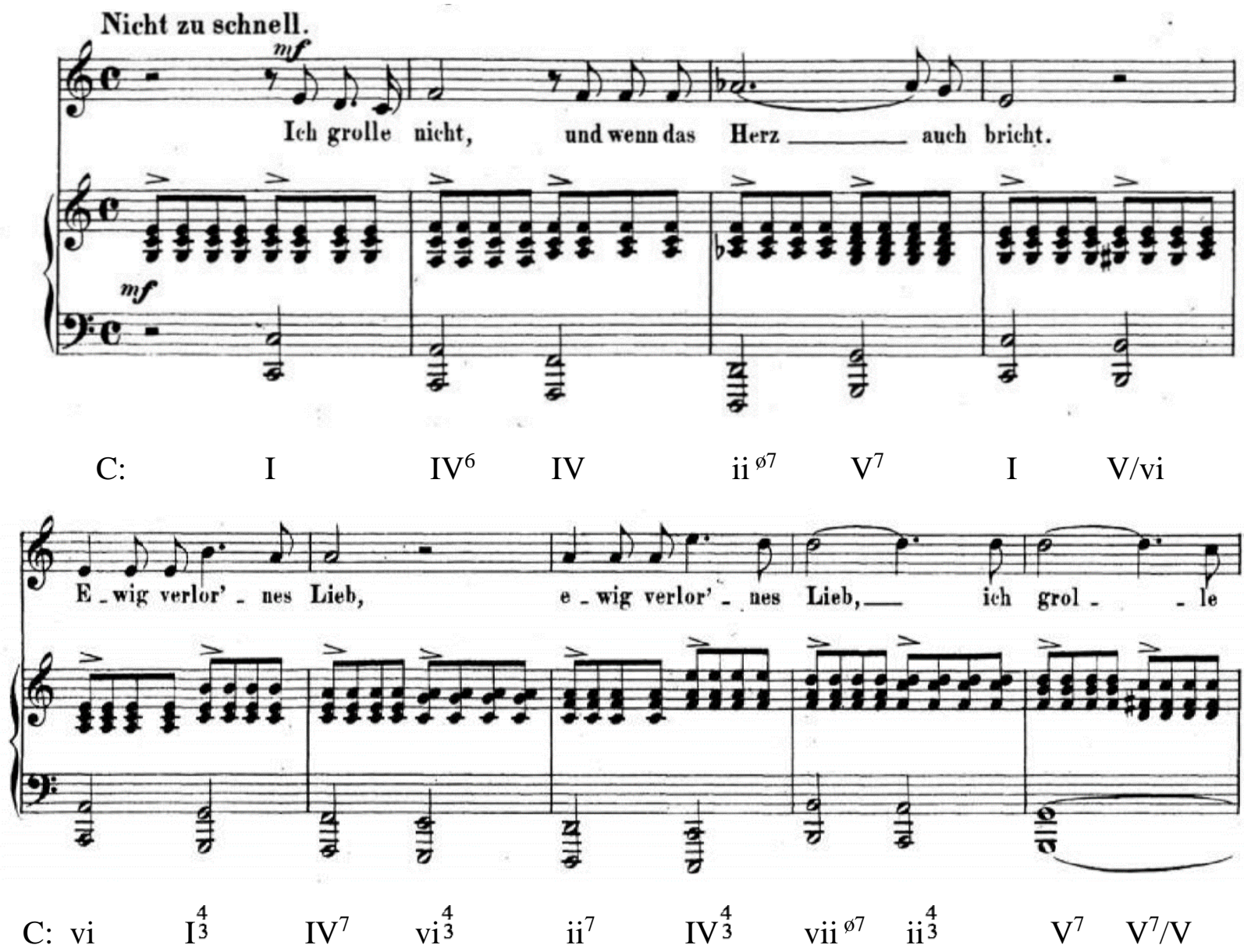

Figure 5-28. Schumann: "Ich grolle nicht," mm. 1-9 
In measure 11, Schumann uses a linear chromatic movement to heighten the word “grolle" ("grudge"). In measures 12 to 16, Schumann modulates to G major and uses a fivemeasure long ascending sequence to emphasize how the poet saw his beloved - "Wie du auch strahlst in Diamantenpracht, es fällt kein Strahl in deines Herzens Nacht" ("How you may gleam in the splendor of diamonds, no light ray falls into the darkness of your heart") (see Figure 5-29):

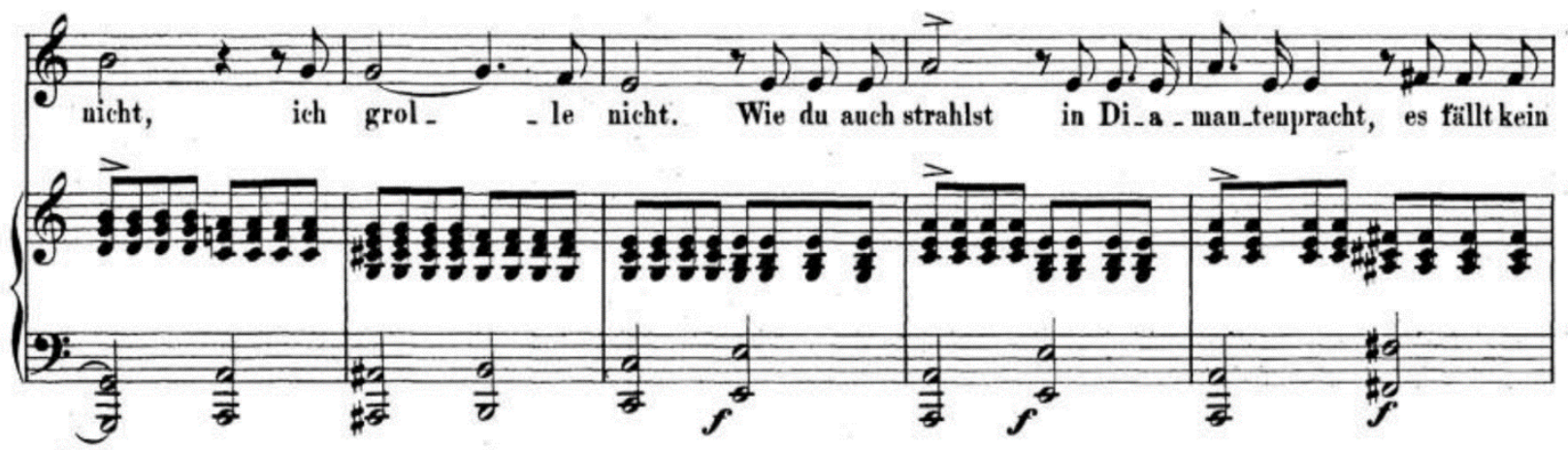

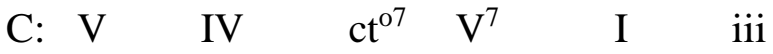

G: vi ii vi ii V/iii

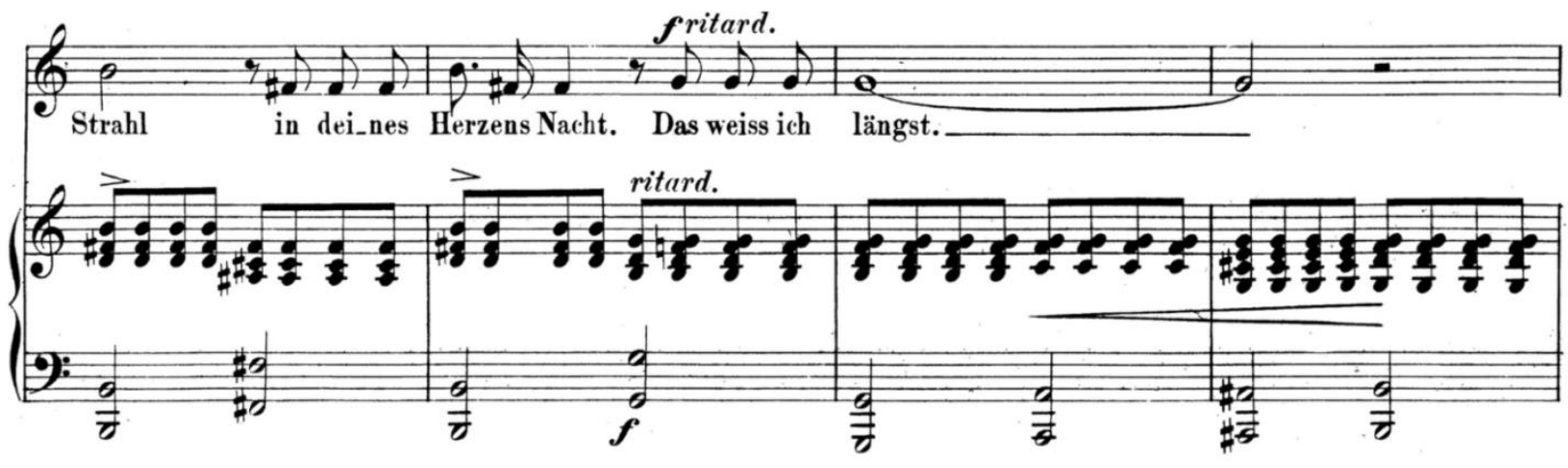

G: iii V/iii iii $\quad$ I

$$
\mathrm{C}: \mathrm{V} \quad \mathrm{V}^{7} \quad \mathrm{~V}^{7} \quad \mathrm{vi}^{7 \text { sus } 6} \quad \mathrm{ct}^{07} \quad \mathrm{~V}^{7}
$$

Figure 5-29. Schumann: "Ich grolle nicht," mm. 10-18 
"Ich grolle nicht" is written in a modified strophic form. In measures 19 to 22,

Schumann initially repeats the opening of the song, then extends it more dramatically by adding repeated notes A, D, and C-sharp or F in the vocal line (see Figure 5-30):

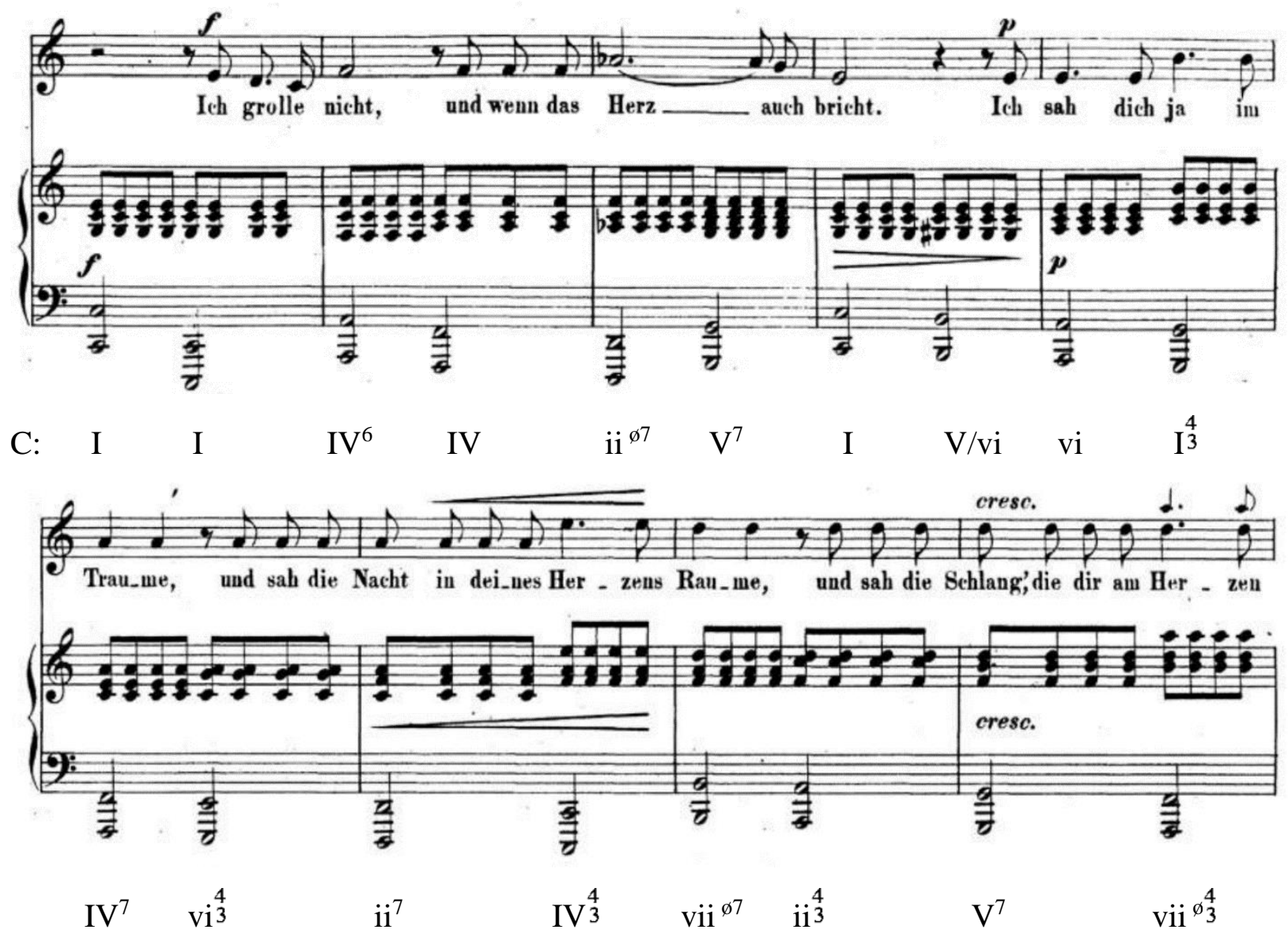

Figure 5-30. Schumann: "Ich grolle nicht," mm. 19-27

The climax begins at measure 27 when Schumann offers an alternate melody, as the high notes are another option for the singer to use which heightens the intensity of the music. Then Schumann concludes the vocal line with two statements of "Ich grolle nicht," as inconsolable laments (see Figure 5-31): 

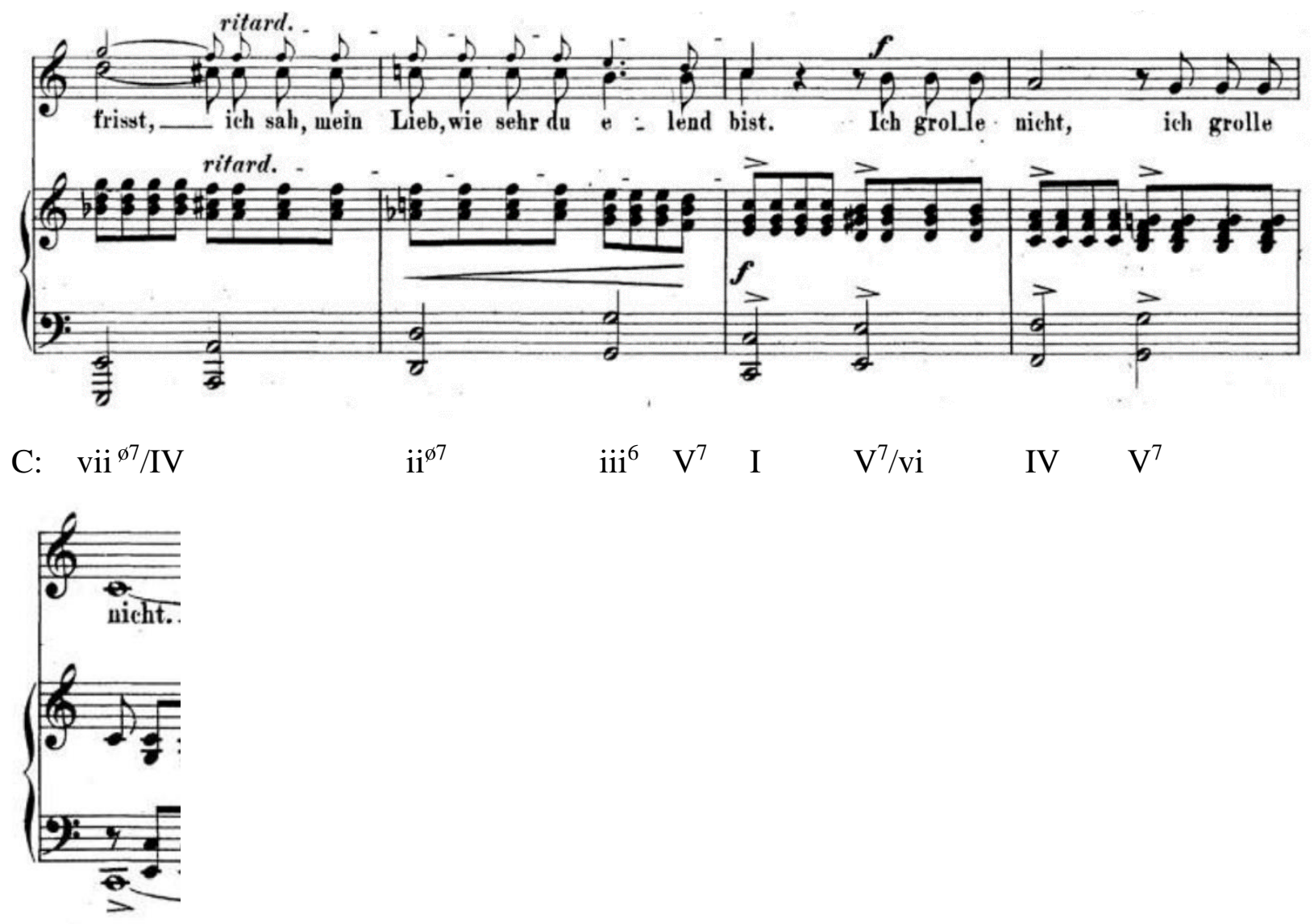

I

Figure 5-31. Schumann: "Ich grolle nicht," mm. 28-32

The brief postlude contains a complicated affection, a mixed feeling of hatred and love. Schumann continues the repeated chords with the dynamic of crescendo to the last three strong chords: I-V-I, as if to say: I am angry (see Figure 5-32): 


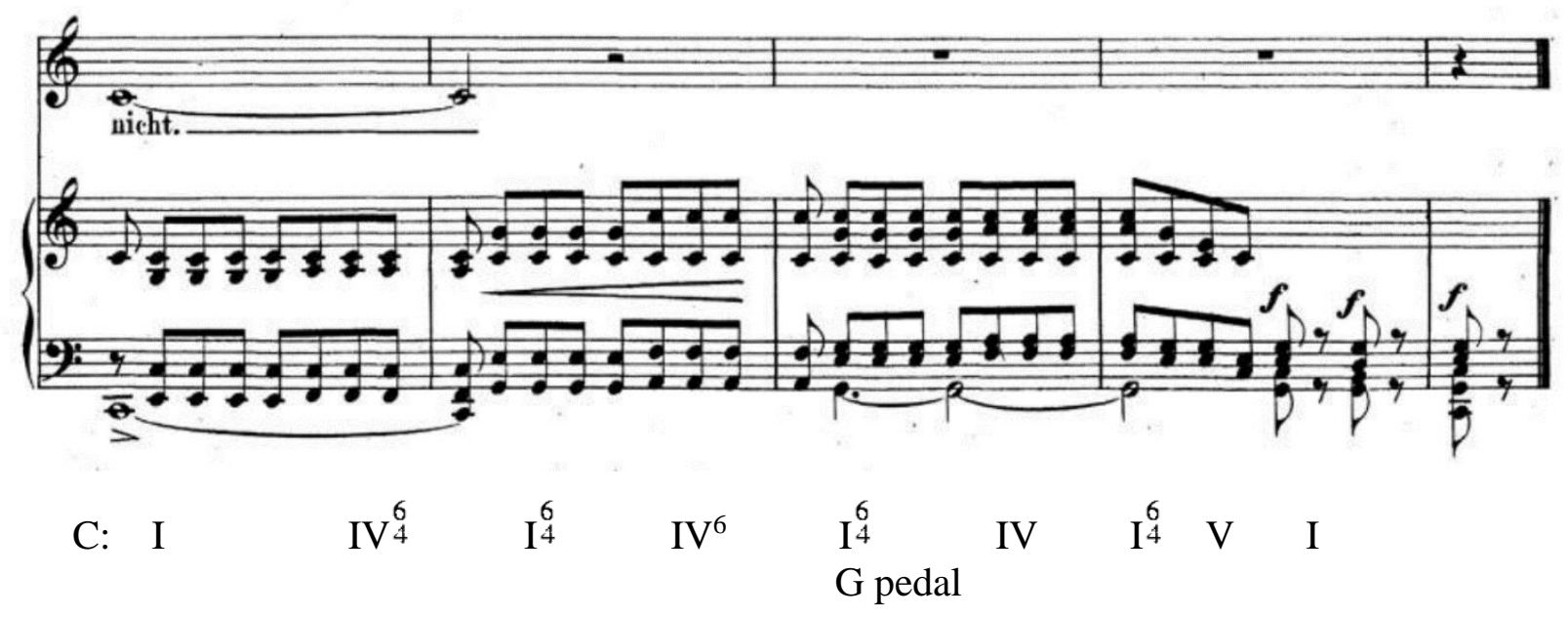

Figure 5-32. Schumann: "Ich grolle nicht," mm. 32-36

This song is in C major, but Schumann demonstrates the word "Herz" ("Heart") and "Lieb" ("Love") with minor mode in measures three, 21, and 29 in order to reveal the poet's true feeling of pain and hurt. Mode mixture is the most common feature that Schumann uses in his text painting. ${ }^{66}$ Once again, Schumann makes much use of repetition in the accompanying style and in the vocal line. Schumann uses seventh chords to enrich the story, and the dense, repetitive chord texture all symbolize the poet's intensity of feeling. The song also marks a turning point in the cycle, as the poet's feelings for the beloved change in his perceived betrayal.

\footnotetext{
${ }^{66}$ Stein, Deborah and Robert Spillman, "The Language of Music," in Poetry into Song: Performance and Analysis of Lieder. (New York: Oxford University Press, 1996), 120.
} 


\section{Und wüssten's die Blumen die Kleinen}

Und wüssten's die Blumen die Kleinen, wie tief verwundet mein Herz, sie würden mit mir weinen zu heilen meinen Schmerz.

Und wüssten's die Nachtigallen, wie ich so traurig und krank, sie liessen frölich erschallen erquickenden Gesang.

Und wüssten sie mein Wehe, die goldnen Sternelein, sie kämen aus ihrer Höhe, und sprächen Trost mir ein.

Sie alle können's nicht wissen, nur Eine kennt meinen Schmerz: sie hat ja selbst zerrissen, zerrissen mir das Herz.
And if the flowers, the little ones knew, How deeply wounded my heart is. They would weep with me, To heal my pain.

And if the nightingales knew, How sad and sick I am, They would let restorative Song cheerfully resound.

And if they knew my hurt, The little golden stars, They would come down from their heights And speak consoling words to me.

None of them can know it, Only one woman knows my pain: She herself has torn apart, Torn apart my heart. ${ }^{67}$

Key: A minor

Form: Modified strophic

Accompanying Style: Tremolando and arpeggiated figures

Predominant Characteristics of Vocal Line: Descending scale fragments, narrow range

In this song, the poet is in secret pain and reflects on the sympathy nature would have for him if it only knew: the flowers, the nightingales, and the golden stars. The poem is divided into four stanzas with Schumann using descending perpetual tremolando figures to represent the singing of the nightingales, the stars falling from the sky, and the poet's fragile state of grief. When the poem turns to speak of the beloved and his torn heart, Schumann ferociously terminates the tremolando with dramatic chords and a virtuosic postlude.

${ }^{67}$ Glass, Beaumont, Schumann's complete song texts. (Genesco, NY: Leyerle Publications, 2002). 67. 
"Und wüssten's die Blumen die Kleine" changes the mood from the previous song "Ich grolle nicht" from the powerful chordal texture in C major to the rustling tremolando texture in the relative key of A minor. Schuman includes no tempo marking for this song. He begins the piano and the voice almost simultaneously, with the piano having a dramatic register change in the treble. The first three stanzas are musically identical, as each stanza contains a phrase of eight measures. One of the features between the vocal line and the accompaniment is the descending melody in unison for the most part, a technique of doubling the parts that Schumann has used in previous songs in the cycle. In the first stanza, Schumann emphasizes "verwundet mein Herz" (“wounded my heart") with a Neapolitan chord (see Figure5-33): 

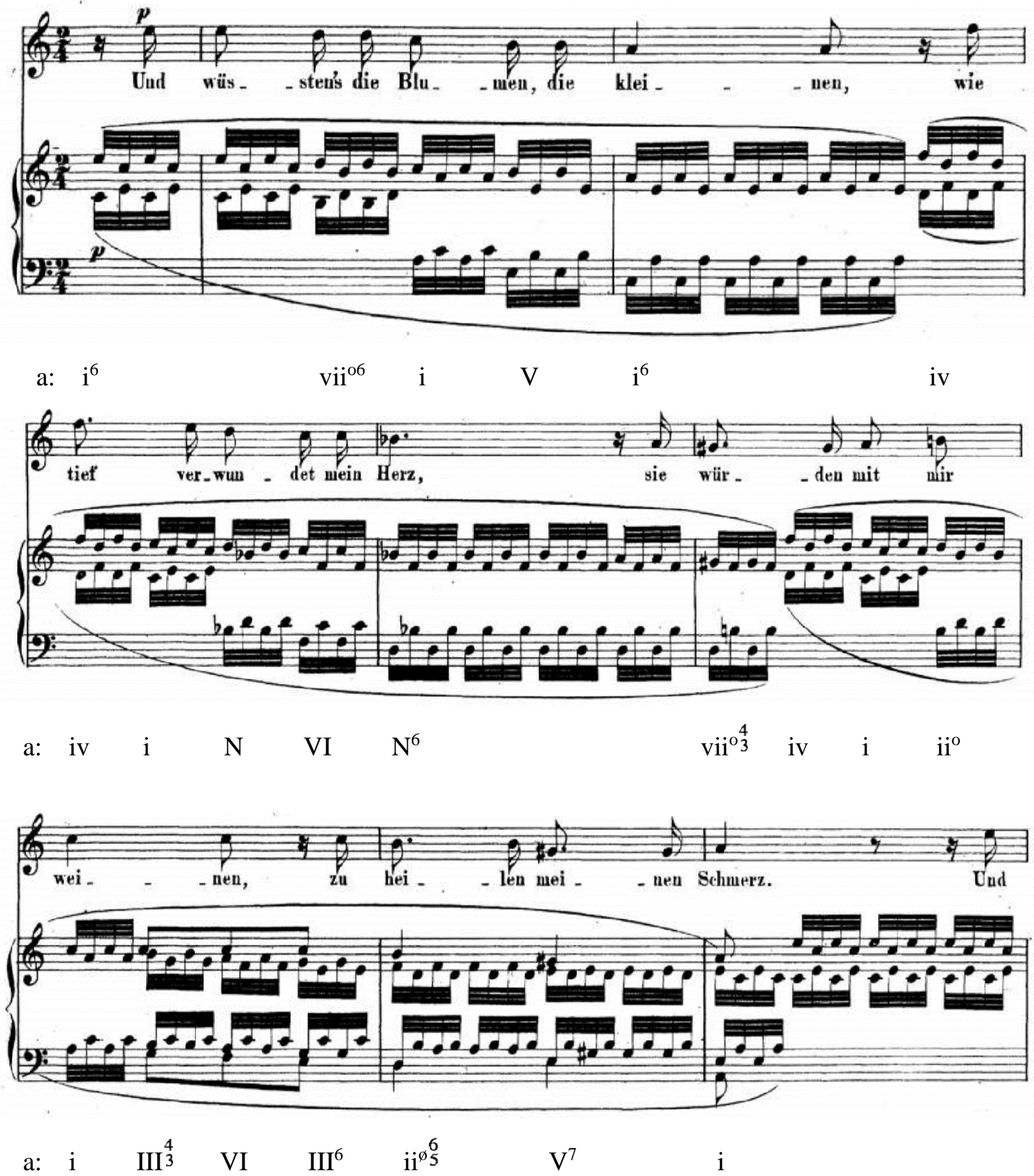

Figure 5-33. Schumann: “Und wüssten’s die Blumen die Kleinen,” mm. 1-8

The poet eventually leaves his imagination of nature and recalls how she has broken his heart. With the word "zerrissen" ("torn apart"), the song takes a dramatic turn. Schumann not 
only uses two chromatic harmonies to emphasize this word, but also two staccato articulations.

Subsequently, the half rest symbolizes his heart abruptly "ceasing" as the illusion of love is shattered (see Figure 5-34): 


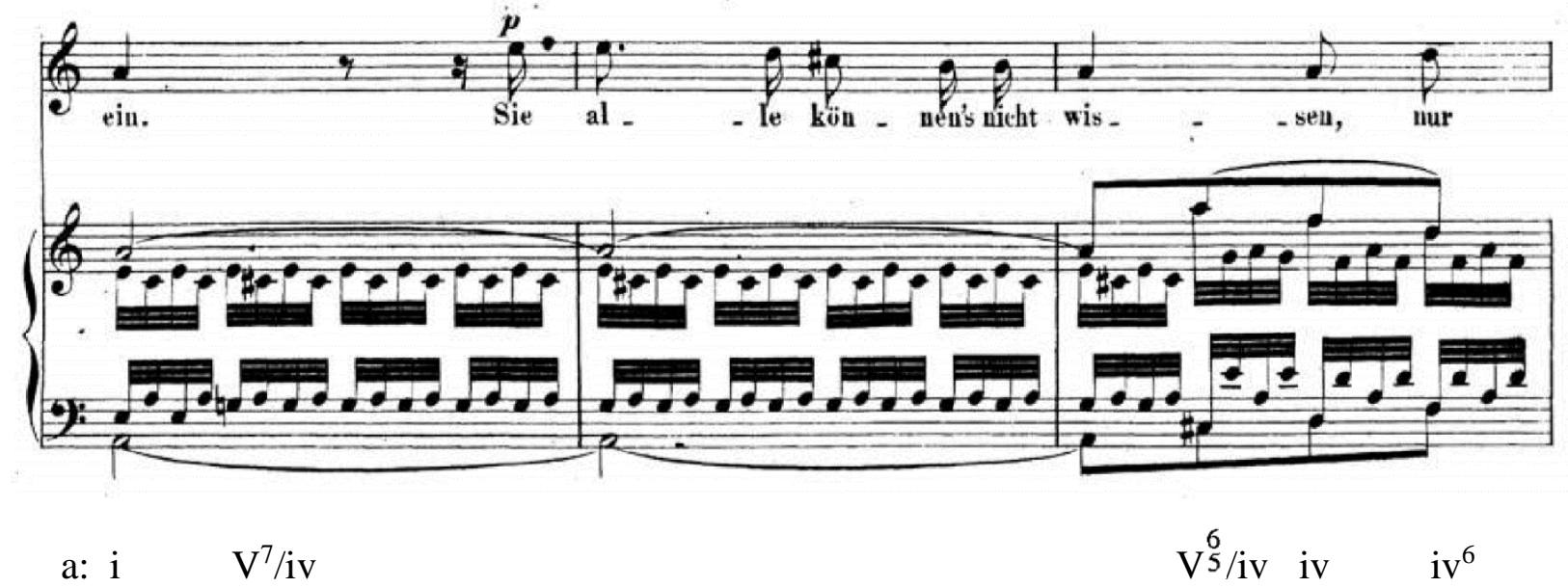

\section{F: $\quad \mathrm{vi}^{6}$}
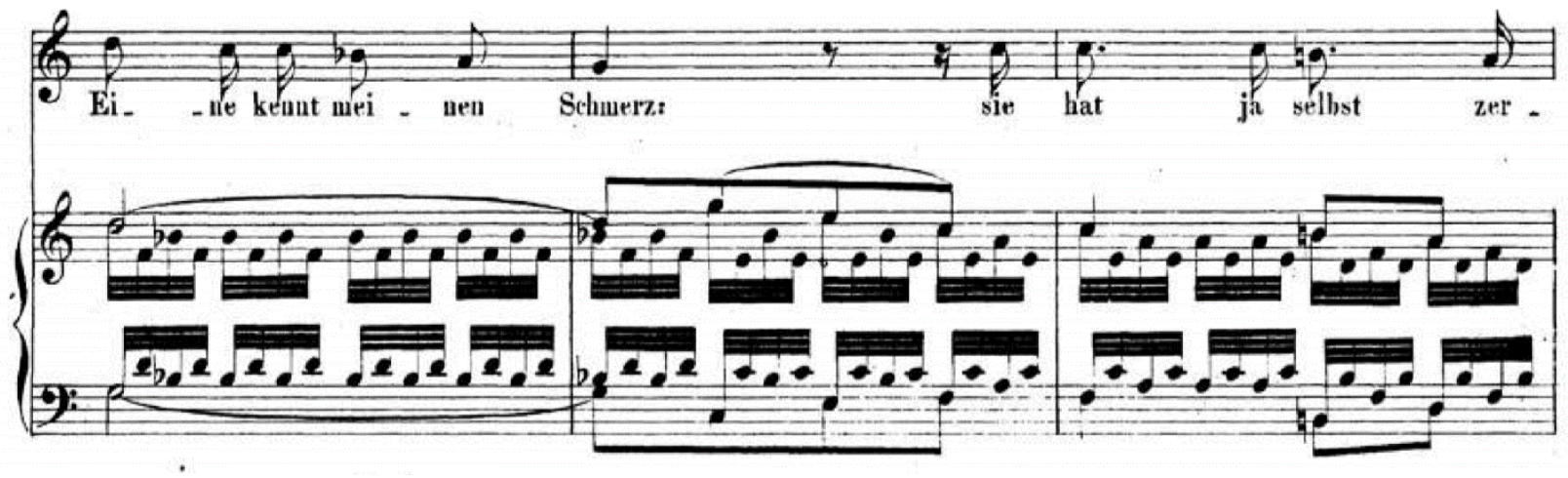
$\mathrm{F}: \mathrm{ii}^{7}$
$\begin{array}{llll}\mathrm{V}^{7} & \mathrm{~V}^{6} & \mathrm{I}^{7} & \mathrm{I}^{7}\end{array}$

a: $\mathrm{VI}^{7} \quad$ ii $^{\mathrm{o}} \quad \mathrm{ii}^{6}{ }^{6}$

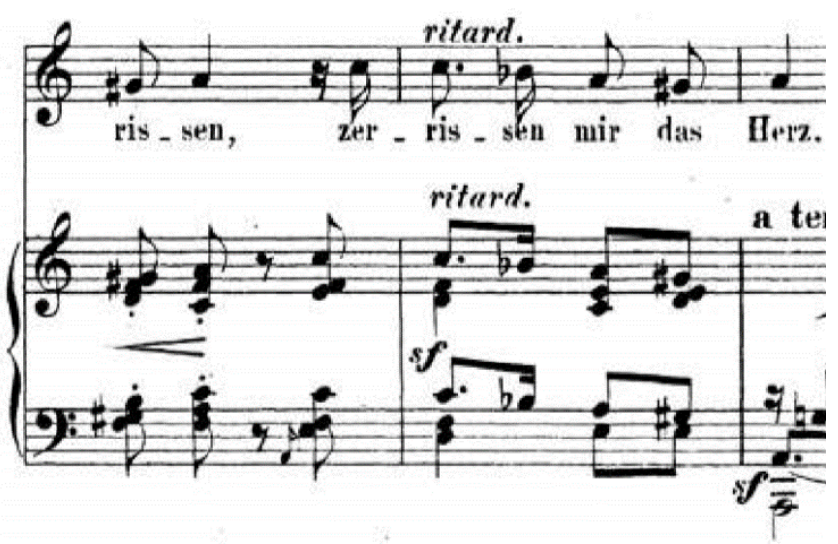

a: vii $^{\circ}{ }_{2}^{4} \mathrm{VI} \quad \mathrm{VI}^{4} \quad \mathrm{iv}^{7} \quad \mathrm{~N}^{6} \quad \mathrm{i}^{\frac{6}{4}} \quad \mathrm{~V}^{7} \quad \mathrm{i}$

Figure 5-34. Schumann: "Und wüssten's die Blumen die Kleinen,” mm. 24-32 
In the piano postlude, Schumann expands the dimension of Heine's poem by adopting the integration of dramatic sixteenth-note triplets in the right hand, a dotted rhythmic figure, and sustained notes in the left hand in order to elaborately illustrate the last sentence "zerrissen mir das Herz." ("torn apart my heart"). Structurally, measures thirty-four and thirty-five are identical with measures thirty-two and thirty-three, the repetition is perhaps to highlight the painful emotion punctuated by the sforzando. The postlude perhaps also aims to simultaneously express the woman's cruelty and the poet's pain (see Figure 5-35):

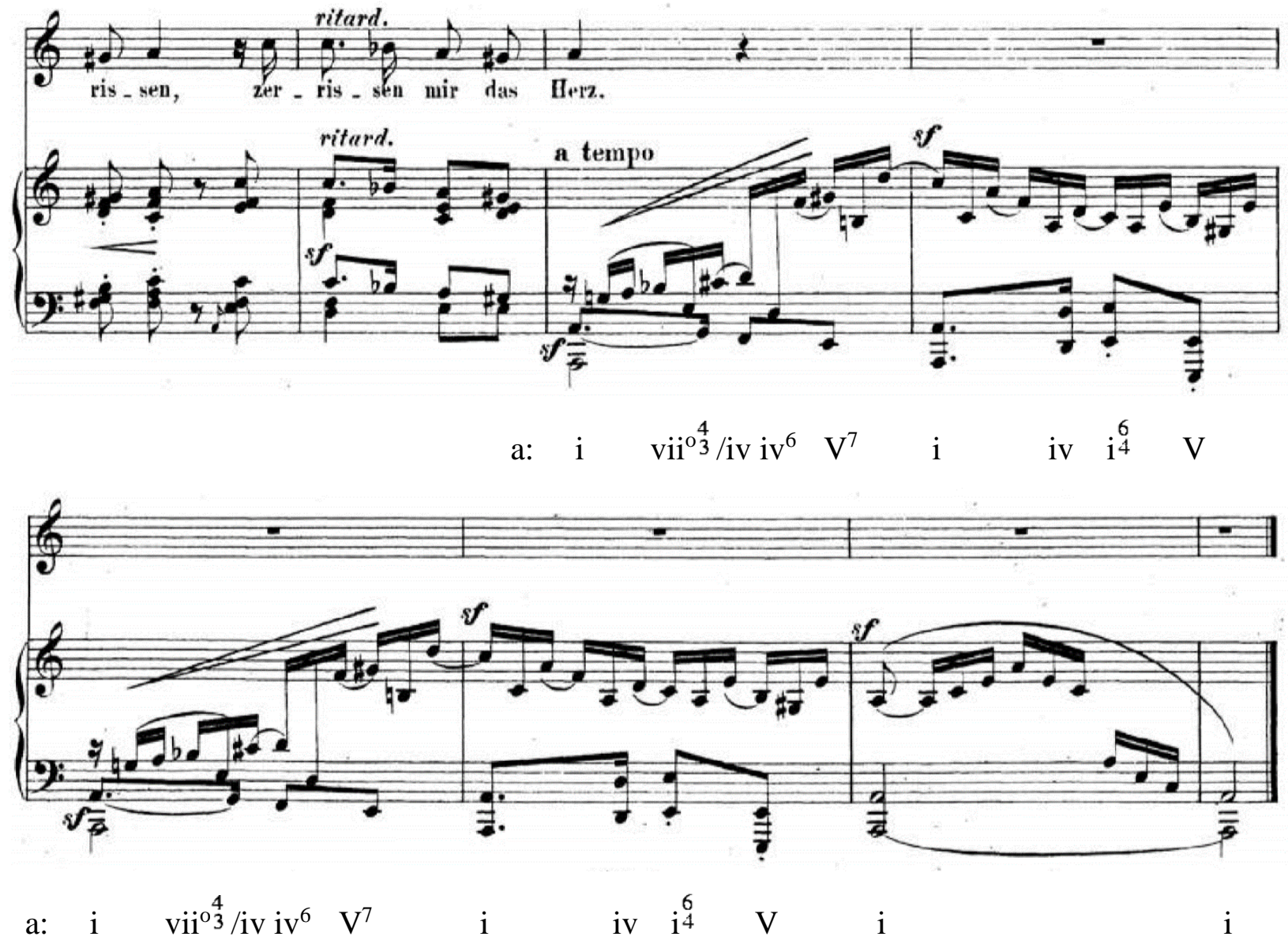

Figure 5-35. Schumann: “Und wüssten's die Blumen die Kleinen,” mm. 30-37 
Schumann tends to apply a repetitive pattern in a song as an accompanying figure. In this song, he uses a fast tremolando throughout. Schumann's compositional technique of using restless, quiet tremolando as the accompaniment texture makes the music extremely delicate and fragile and yet melodious as the vocal line is mostly doubled in the piano. "Und wüssten's die Blumen die Kleine" is the first song in the cycle which has a startlingly dramatic ending. The last verse of the poem, "She herself has broken my heart," gives rise to the raging storm that follows. ${ }^{68}$ The dramatic story of this poem depicts the unstable emotional state of the poet.

${ }^{68}$ Rosen, Charles, "Mountains and Song Cycles," in The Romantic Generation. (Cambridge, Massachusetts: First Harvard University Press, 1998), 211. 


\section{Das ist ein Flöten und Geigen}

Das ist ein Flöten und Geigen, Trompetten schmettern darein. Da tantz wohl im Hochzeitreigen die Herzallerliebste mein.

Das ist ein Klingen und Dröhnen, ein Pauken und ein Schalmein; dazwischen schluchzen and stöhnen die lieblichen Engelein.
There is a fluting and fiddling, Trumpets blare into it. The darling of my heart is probably Dancing the wedding dance in there.

I hear ringing and droning, Drumming and shawming; In the midst of it all, the lovely Little angels are sobbing and moaning. ${ }^{69}$

Key: D minor

Form: Strophic

Accompanying Style: Constant sixteenth-note passagework, waltz bass

Predominant Characteristics of Vocal Line: Repeated notes, triadic outline

In this poem, Heine begins by depicting a spectacular wedding event with dancing, accompanied by flutes, fiddles, trumpets, and drums. Schumann uses a 3/8 meter for the dance rhythm. This is the noise of the wedding reception of his beloved but including also the weeping and moaning of angels. "In German folk songs, angels are occasionally depicted as singing over disappointed lovers; sometimes they console them and sing them to rest."70

Schumann begins with a four-bar introduction, which sets the mood for the scene. The right hand plays legato, dizzying sixteenth notes while the left hand plays a leaping, percussive waltz-style bass figure. Schumann keeps the repetitive accompanying pattern for the entire song. In the opening measures, the downbeat $\mathrm{A}$ in each measure imitates the drumming and sets the waltz-like dance rhythm. Schumann begins with a dissonant harmony and uses chromatic harmonies throughout to highlight the tension of the scene (see Figure 5-36):

\footnotetext{
69 Glass, Beaumont, Schumann's complete song texts. (Genesco, NY: Leyerle Publications, 2002). 67-8.

${ }^{70}$ Elaine Brody and Robert A. Fowkes, "The New Style of Piano Accompaniments," in The German Lied and Its Poetry. (New York: New York University Press, 1971), 112.
} 

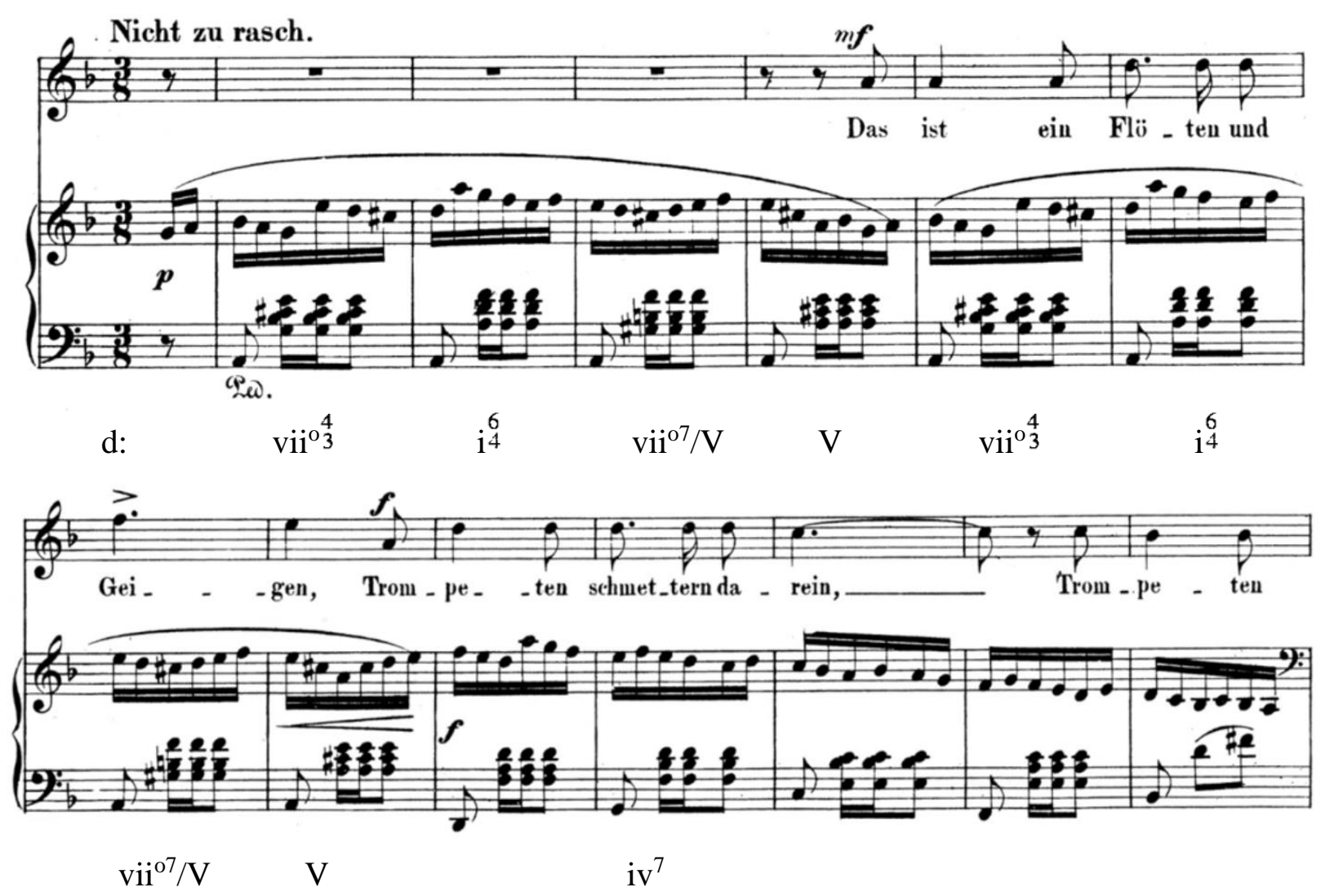
$\mathrm{F}: \quad \mathrm{ii}^{7}$
$\mathrm{V}^{7}$
$\mathrm{I}^{7}$
$\mathrm{V}^{7} / \mathrm{ii}$

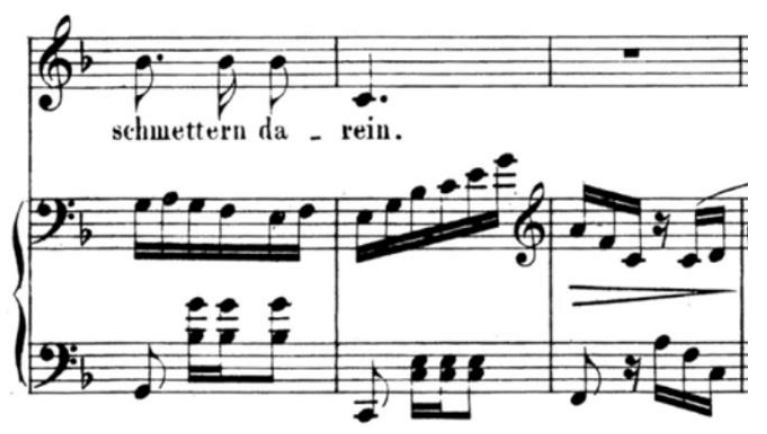

F: ii $\quad \mathrm{V}^{7} \quad \mathrm{I}$

Figure 5-36. Schumann: "Das ist ein Flöten und Geigen," mm. 1-16

Schumann sets the end of the first sentence of the first stanza in the key of F major, and then modulates to $\mathrm{G}$ minor in the brief piano interlude. In the second section, $\mathrm{G}$ minor as a new tonality and subdominant of D minor, heightens the expression. The poet's beloved was likely 
dancing in this wedding vision, and Schumann repeats the words "die Herzallerliebste mein" ("my darling") to emphasize the affection of the poet. In the following interlude, Schumann uses the tonicization of A major in measures 33 and 34 as a bridge to connect to the second stanza, a flawless transition to link to D minor (see Figure 5-37): 


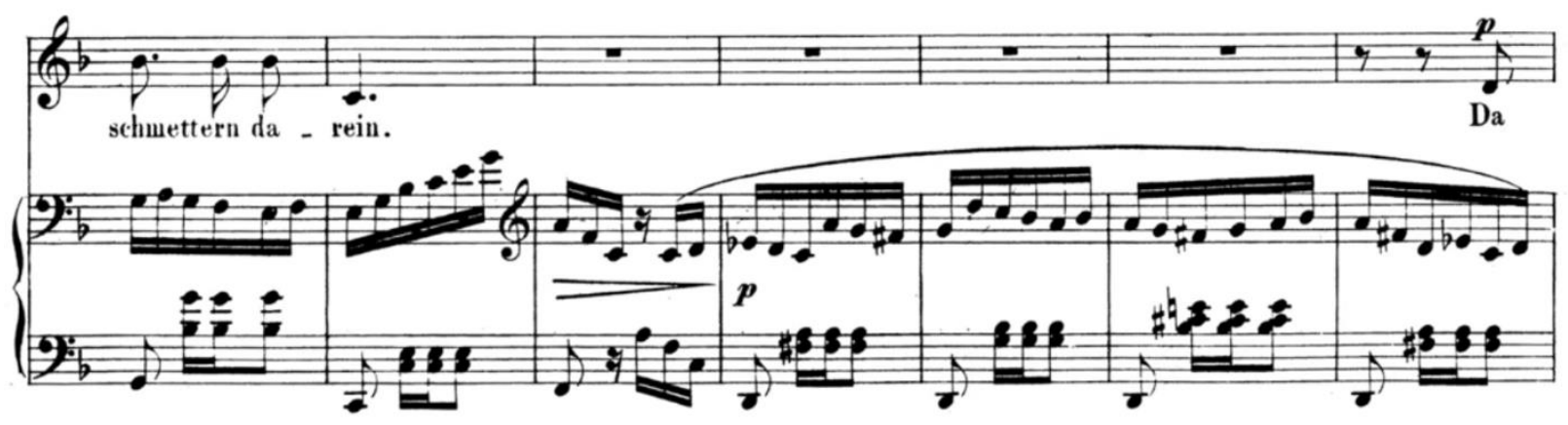

F: ii

$$
\mathrm{V}^{7} \quad \mathrm{I} \quad \mathrm{V} / \mathrm{ii}
$$

$$
\mathrm{g}: \mathrm{V} \quad \mathrm{i}^{6} \quad \operatorname{vii}^{\circ}{ }^{4} / \mathrm{V} / \mathrm{V}
$$

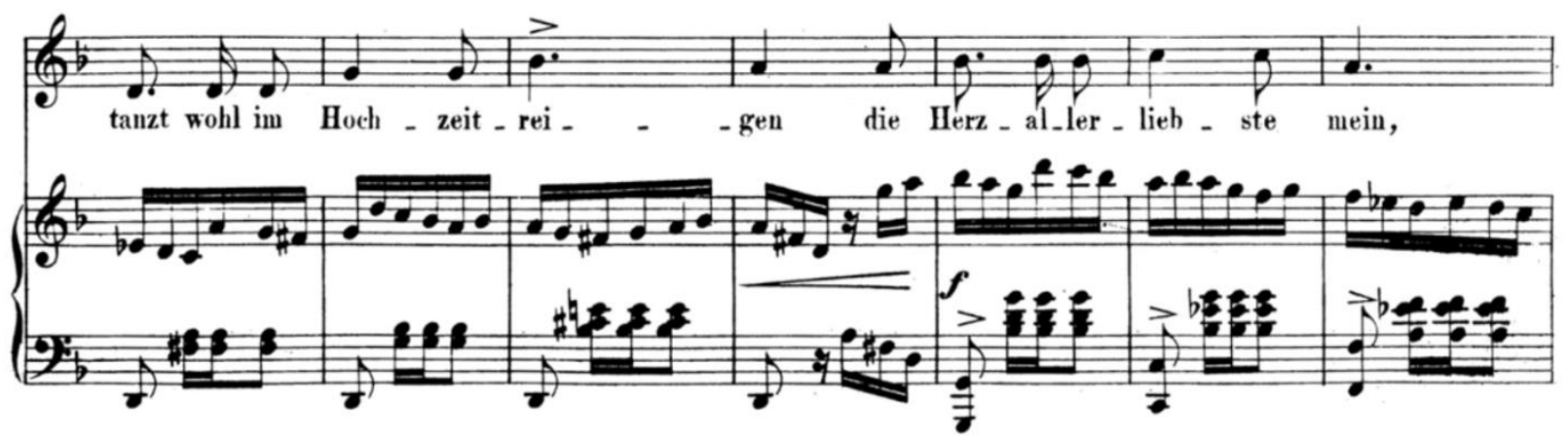
V
$\mathrm{i}^{6}$
vii $^{\circ} \frac{4}{2} / \mathrm{V} \quad \mathrm{V}$

$\mathrm{Bb}: \mathrm{vi}$

ii $^{7} \quad \mathrm{~V}^{7}$

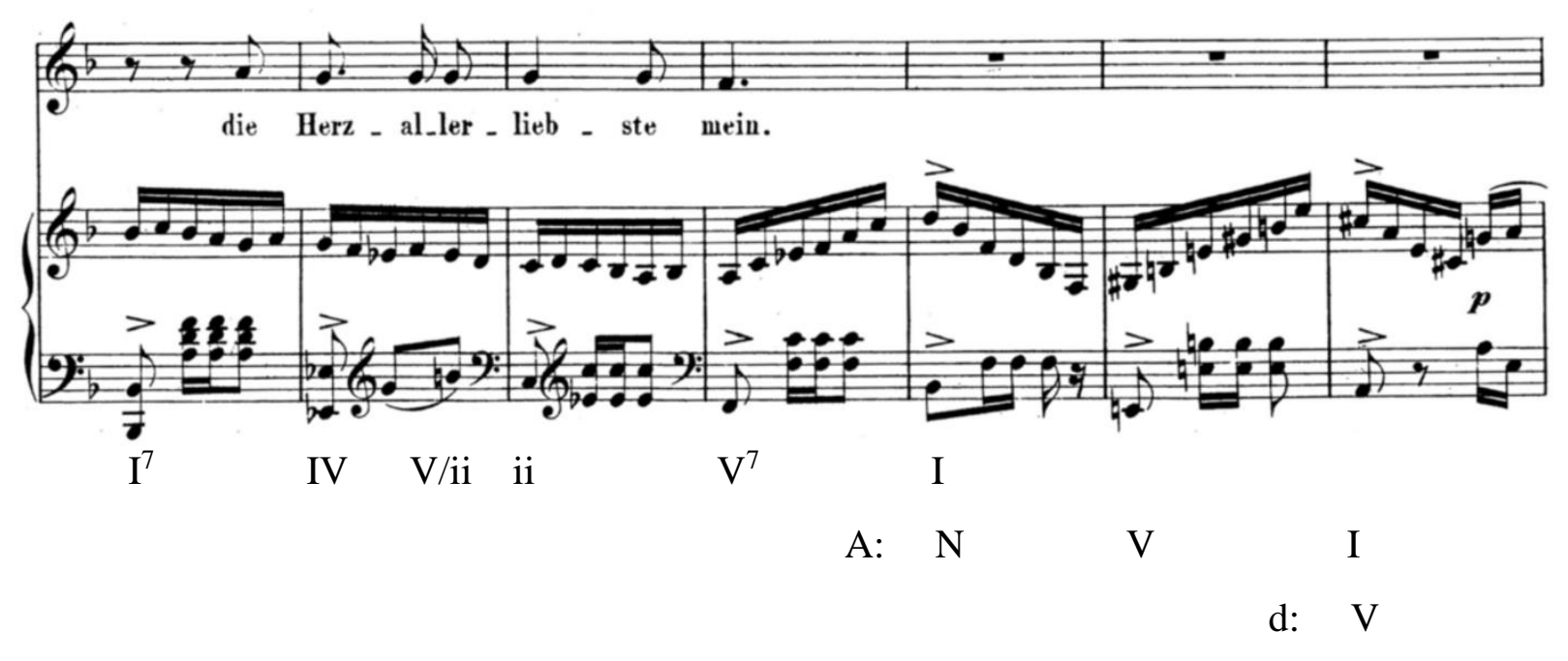

Figure 5-37. Schumann: "Das ist ein Flöten und Geigen,” mm. 14-34 
This song has a remarkable sixteen-measure piano postlude that continues the whirlwind passagework. The sudden accented F-sharp diminished seventh chord in the third beat of measure 72 creates a dramatic moment, but soon after, a four-measure repeated pattern under a diminuendo indicates the scene is fading. Schumann uses a descending chromatic scale in both hands beginning in measure 80 to lead to a surprising end in pianissimo D major (see Figure 538): 


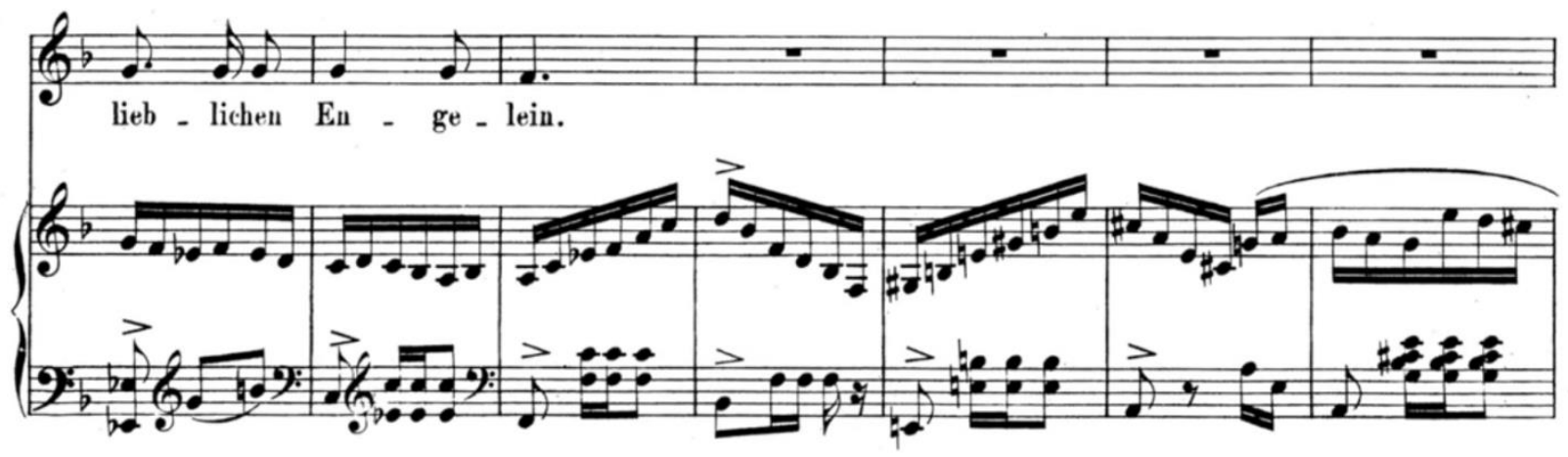

Bb: IV V/ii ii $\quad \mathrm{V}^{7} \quad$ I

A: $\mathrm{N} \quad \mathrm{V} \quad \mathrm{I}$

$\mathrm{d}: \mathrm{V} \quad \operatorname{vii}^{4}{ }^{4}$

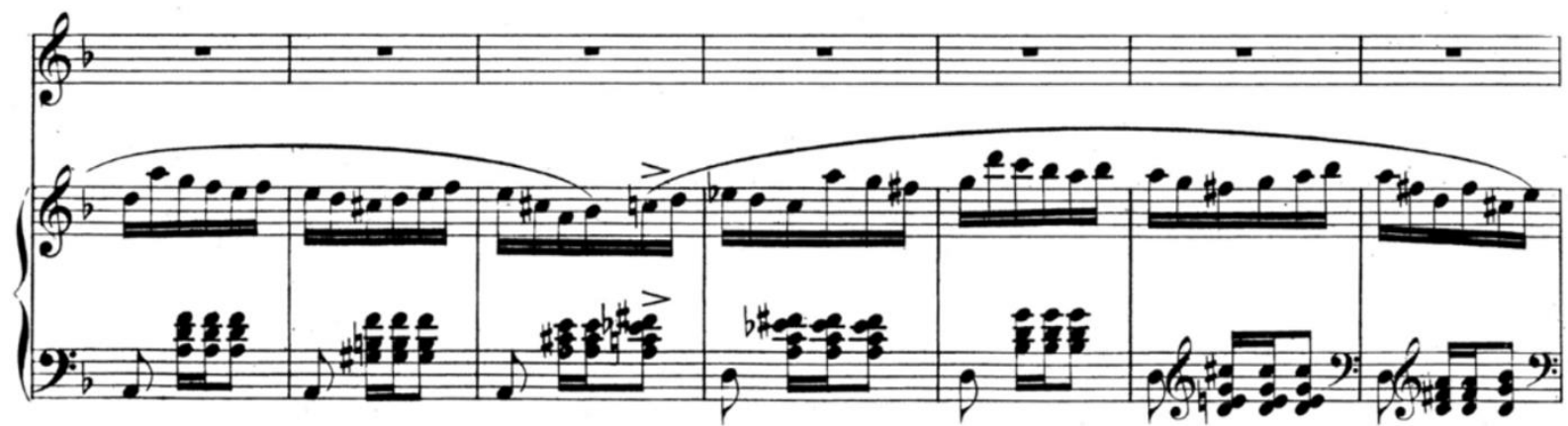
d: $\quad i_{4}^{6}$
$\mathrm{vii}^{07} / \mathrm{V} \quad \mathrm{V} \operatorname{vii}^{6}{ }^{6} / \mathrm{iv}$
iv 4
vii $^{\text {o }}$
$\mathrm{V}^{7} /$ iv iv $^{4}$

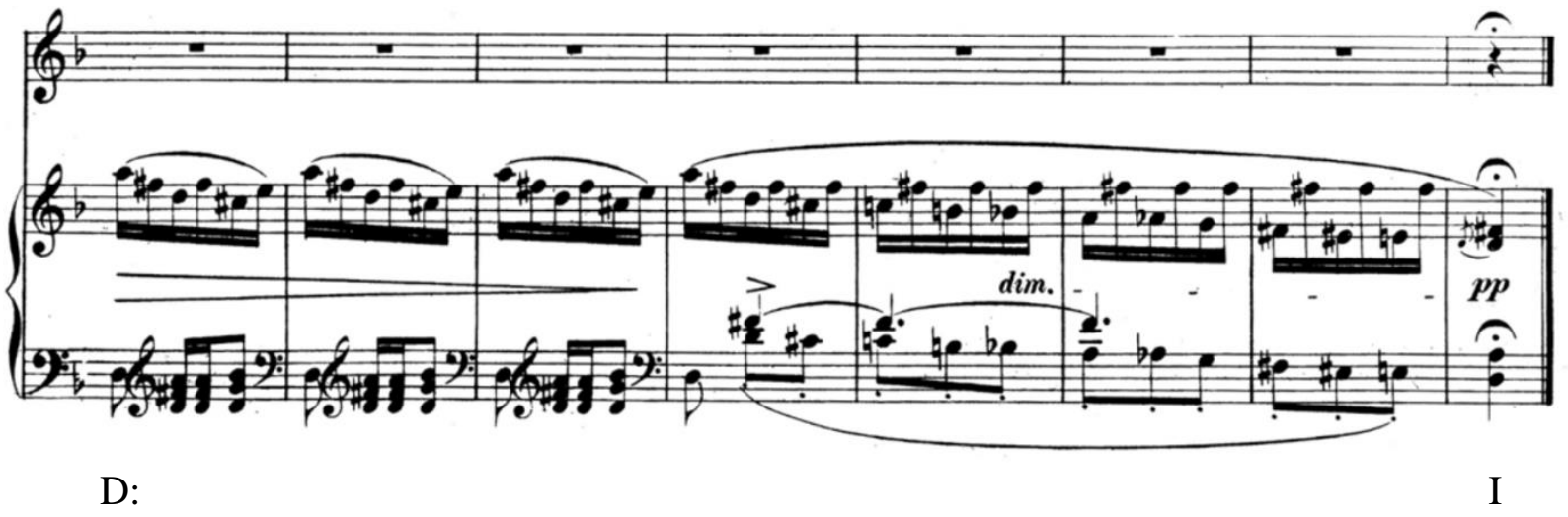

Figure 5-38. Schumann: "Das ist ein Flöten und Geigen,” mm. 63-84 
With "Das ist ein Flöten und Geigen," Schumann presents a vivid scene by using the dance rhythm and continuous running passagework in the right hand of the piano depicting the flutes, fiddles, trumpets, and drums. In the piano postlude, the technical challenges include articulating the left-hand chords accurately with the large leaps against the constant sixteenth notes of the right hand. Overall, this seemingly happy atmosphere is a camouflage for the poet's self-pity and ironically, "in the resentful mind the harmonies have become discordant, the melodies distorted - the musical equivalent of Heine's contemptuous description."71

\footnotetext{
${ }^{71}$ Sams, Eric, "The Songs," in The Songs of Robert Schumann. (Bloomington and Indianapolis: Indiana University Press, 1993). 116.
} 


\section{Hör' ich das Liedchen klingen}

Hör' ich das Liedchen klingen, das einst die Liebste sang, so will mir die Brust zerspringen von wildem Schmerzendrang.

Es treibt mich ein dunkles Sehnen hinauf zur Waldeshöh', dort löst sich auf in Thränen mein übergrosses Weh.
If I happen to hear the little song That once my dearest sang, Then my breast wants to burst From the pressure of a wild pain.

A dark longing drives me up To the high forest; There my enormous misery Dissolves into tears. ${ }^{72}$

Key: G minor

Form: Through-composed

Accompanying Style: Layered, arpeggiated

Predominant Characteristics of Vocal Line: Folk song-like, descending intervals

In "Hör' ich das Liedchen klingen," ("If I happen to hear the little song,") Heine expresses feelings of pain and sorrow as the poet hears a little song once sung by his beloved, a sorrow that leads to despairing tears. This song represents a dramatic mood change from the previous song.

Beginning in $\mathrm{G}$ minor with a four-measure piano introduction that presents the "little song" in the soprano register, Schumann uses three voices in the piano to distinguish the melody, the layered middle arpeggiation and the bass accompaniment. He also uses syncopation to present the upper melody which highlights the mood and unsettled feeling. Moreover, in the introduction, this sentimental story is introduced by the descending arpeggiated figure with a "Langsam" ("Slow") tempo and a piano dynamic. When the voice enters in measure five, the four-measure vocal melody is closely related to the piano introduction (see Figure 5-39):

\footnotetext{
72 Glass, Beaumont, Schumann's complete song texts. (Genesco, NY: Leyerle Publications, 2002). 68.
} 

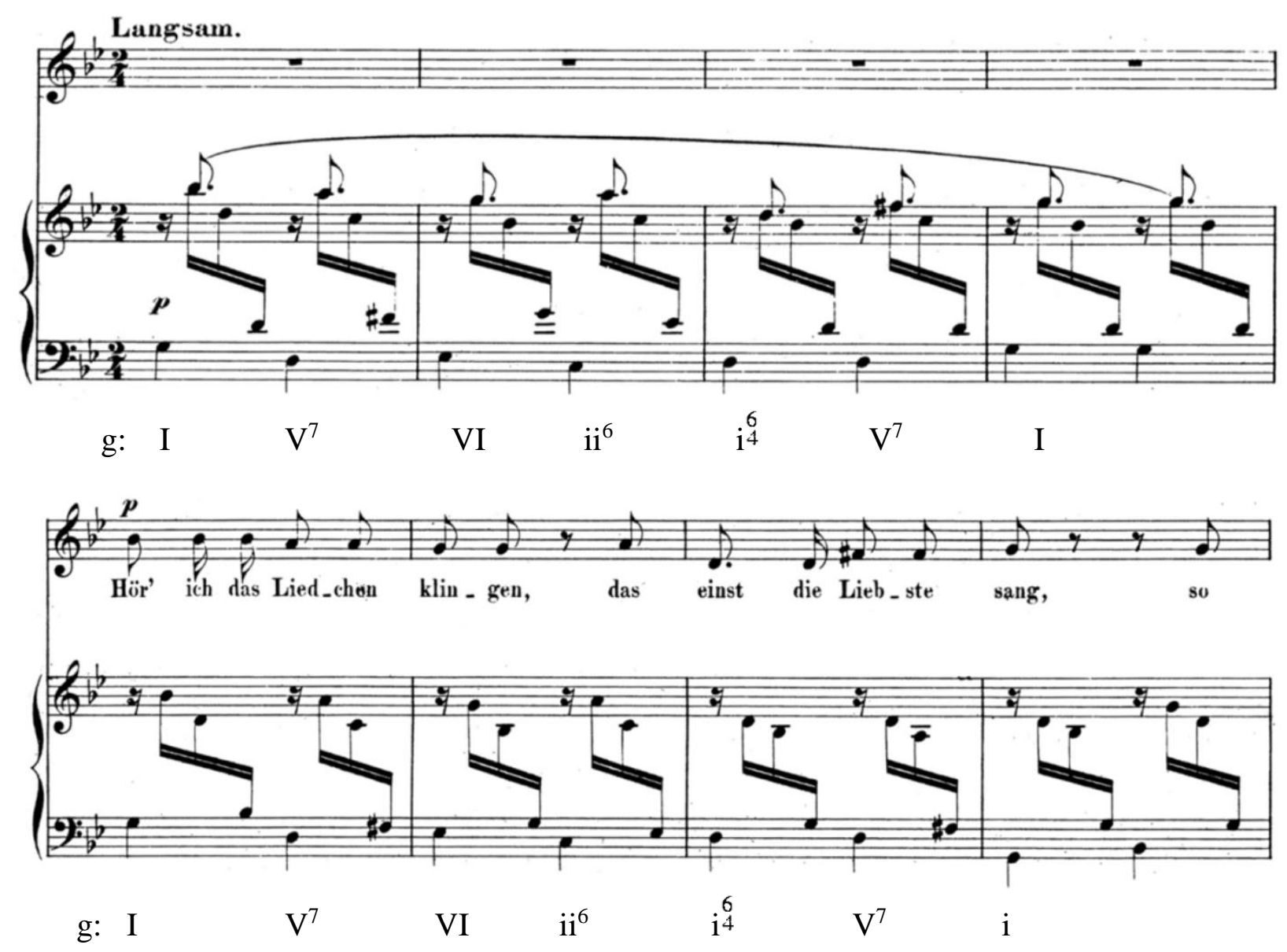

Figure 5-39. Schumann: "Hör' ich das Liedchen klingen,” mm. 1-8

In measure nine, Schumann represents the internal struggle of the poet by utilizing a modulation from $\mathrm{G}$ minor to the subdominant key of $\mathrm{C}$ minor. In addition, the vocal line starts to ascend to the highest peak of D-flat, part of a Neapolitan chord which is the first chromaticism in this song. Schumann uses it for stressing the degree of pain of the poet, as Heine describes "wildem" ("savage") pain. In the piano part, Schumann sustains the top melody in the right hand so that it becomes syncopated suspensions which represent the poet's painful memory. In measure 12 , the song moves from the first stanza to its second, and modulates to a new key of Bflat (see Figure 5-40): 


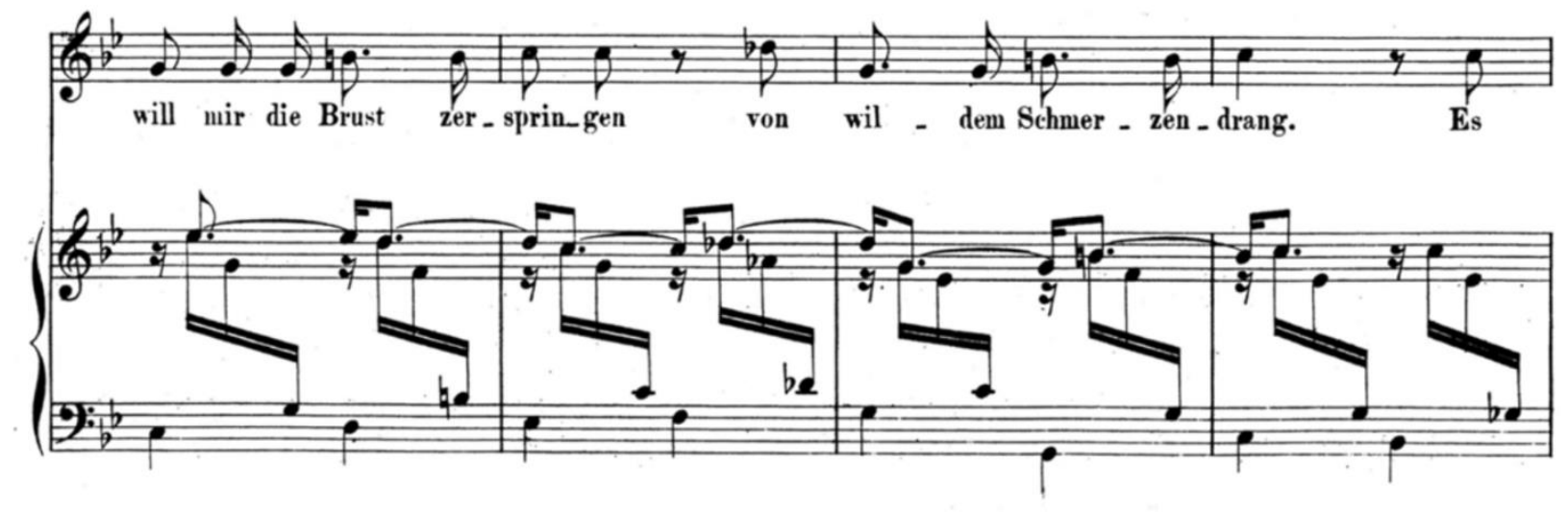

g: iv

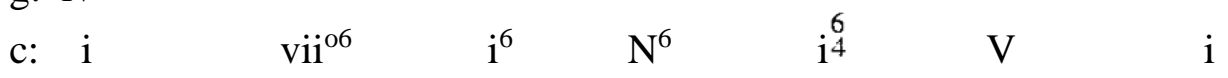

Bb: ii

Figure 5-40. Schumann: "Hör' ich das Liedchen klingen," mm. 9-12

In the second stanza, Heine describes a dark longing that drives him up to the high forest, where he suffers an incredible misery dissolved ultimately into tears. From measures 13 to 16 , Schumann uses a downward sequence to represent the descent of the poet's emotions, and in measure 18, Schumann emphasizes the word "Thränen" ("tears") in the voice by using the note A, an accented passing tone, to prepare for the most dramatic music of the song in the postlude (see Figure 5-41): 

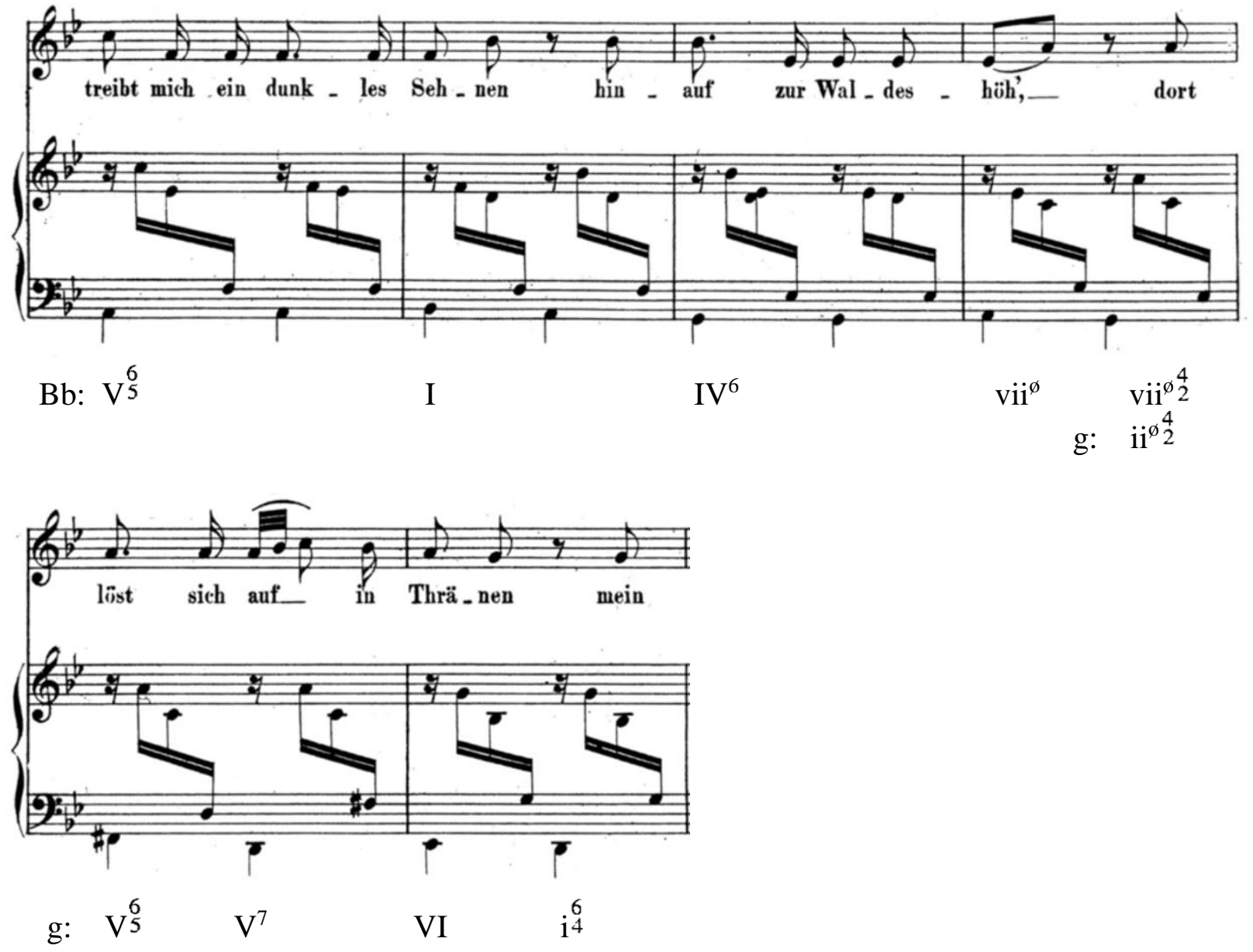

Figure 5-41. Schumann: "Hör' ich das Liedchen klingen,” mm. 13-18

The postlude in the piano begins as the voice sings the words "übergrosses Weh." (“enormous pain.”) Schumann brings back the original melody from the introduction but this time sustained. In measures 21 to 26 , Schumann simultaneously uses several levels of texture to expand this song, especially the inner voice level. First, the melody is notated as a doublestemmed note from measure 21 to 23 . Subsequently, with the sustaining tonic note at the top, three lower voices represent ascending lines with the dynamics gradually getting louder, with the alto part particularly chromatic. In addition, Schumann's use of a chromatic scale creates an intense harmonic change on every eighth note during measures 24 to 26 . On the second beat of 
measure 26 , a dissonant chord played by the left hand is powerfully striking while the right hand plays a descending scalar passage. At this moment, with the texture, dynamics and harmony, the epilogue is undoubtedly reaching the climax. Lastly, a soft descending passage in a scalar figure slowly leads to the end (see Figure 5-42):
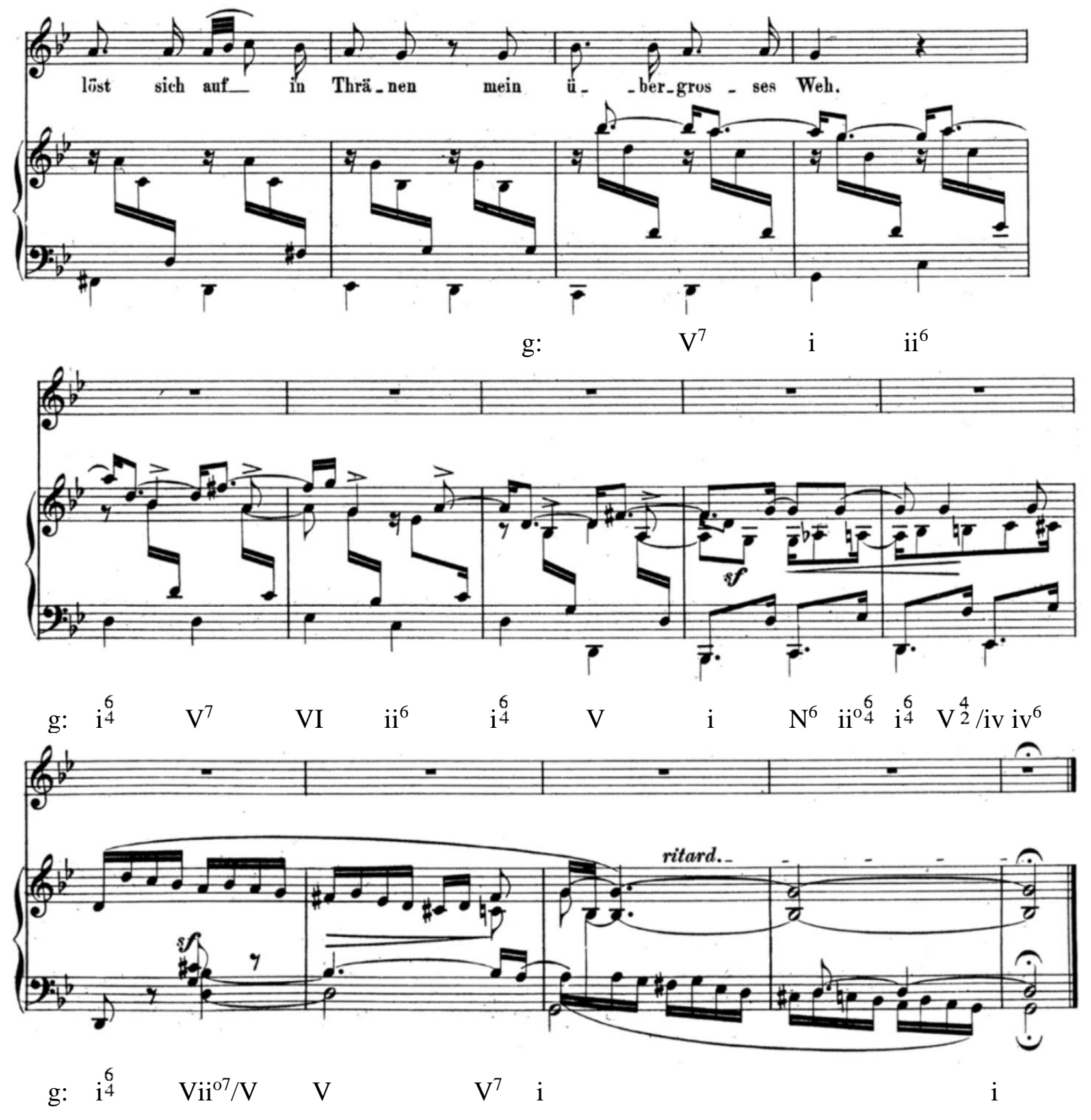

Figure 5-42. Schumann: "Hör' ich das Liedchen klingen," mm. 17-30 
With "Hör' ich das Liedchen klingen," Schumann writes a beautiful melody that overlaps between the voice and the piano. The long expressive postlude is almost a piano solo, as is the entire song. Schumann's "style of writing for the piano includes attention to inner voice levels to the extent that frequently several levels of texture exist simultaneously." ${ }^{.73}$ The technical difficulties of the song in the piano are found in the voicing issues: highlighting the top note melody in the right hand while playing the rest of the notes softly, and during the postlude, the melody is hidden in the layers with accents.

\footnotetext{
${ }^{73}$ Gordon, Stewart, "Robert Schumann," in A History of Keyboard Literature: Music for the Piano and Its Forerunners. (New York: Schirmer, Cengage Learning, 1996). 250-51.
} 


\section{Ein Jüngling liebt ein Mädchen}

Ein Jüngling liebt ein Mädchen, die hat einen andern erwählt, der And're liebt eine And're, und hat sich mir dieser vermählt.

Das Mädchen nimmt aus Ärger den ersten, besten Mann, der ihr in den Weg gelaufen, der Jüngling ist übel dran.

Es ist eine alte Geschichte, doch bleibt sie immer neu, und wem sie just passiret, dem bricht das Herz entzwei.
A boy loves a girl Who has chosen someone else, That someone loves a different girl And has married her.

The girl takes out of annoyance The first best man, Who happens to cross her path, The boy is desolate.

It's an old story, But it remains ever new, And if it has just happened to someone His heart will break in two. ${ }^{74}$

Key: Eb major

Form: Through composed

Accompanying Style: Syncopated and chordal

Predominant Characteristics of Vocal Line: Wide range, repeated notes, and wide intervallic leaps

Heine relates an old and unending story of unobtainable love and a compromise marriage, complicated circumstances that cause heartbreak for the injured person in "Ein Jüngling liebt ein Mädchen,” (“A boy loves a girl.”) However, when Schumann deals with this subject, he uses the bright key of E-flat major and a simple duple meter, in a folk-song like setting. The leaps both in the left hand of the piano and the voice reveal the mood swing of lightness and happiness, as it conflicts with the theme of the poem. Schumann uses a humorous and ironic approach to transform a musical joke into a tragic effect, and he is perhaps the first composer to achieve that. $^{75}$

\footnotetext{
${ }^{74}$ Glass, Beaumont, Schumann's complete song texts. (Genesco, NY: Leyerle Publications, 2002). 69.

75 Rosen, Charles, "Fragments," in The Romantic Generation. (Cambridge, Massachusetts: Harvard University Press, 1998), 58.
} 
This is another song without a tempo marking by Schumann. He begins this song with a four-bar introduction featuring syncopated rhythms and a wide range that represent the jovial mood. He retains this accompanying pattern throughout the song. The tragic element of the poetry is concealed by the humorous music, as Schumann attempts to narrate the story ironically (see Figure 5-43):

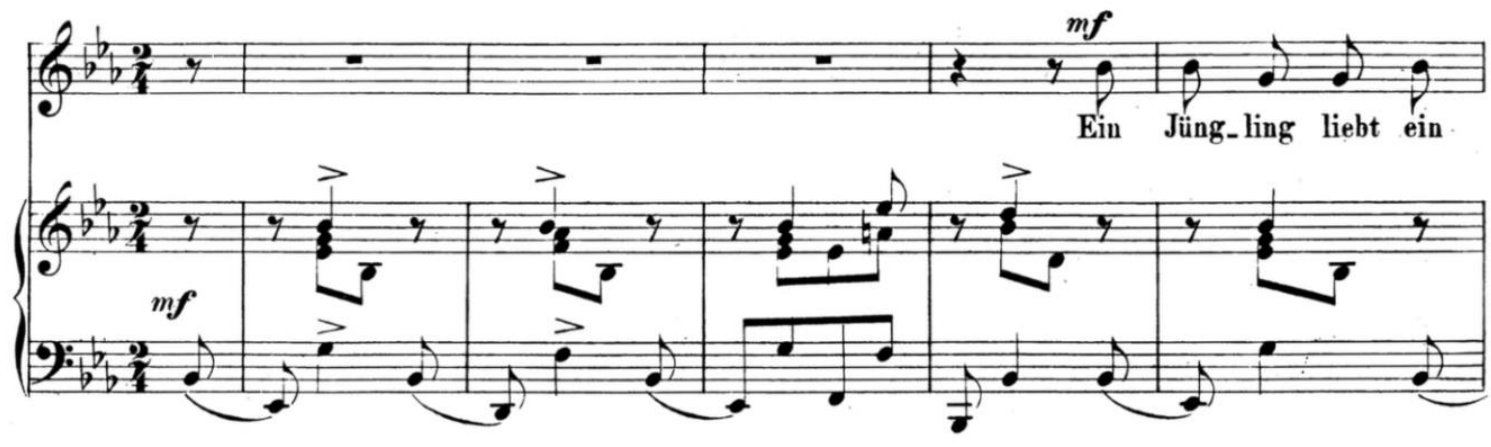
Eb: $\quad$ I
$\mathrm{V}^{6}$
I $\quad \mathrm{V}^{7} / \mathrm{V} \quad \mathrm{V}$
I
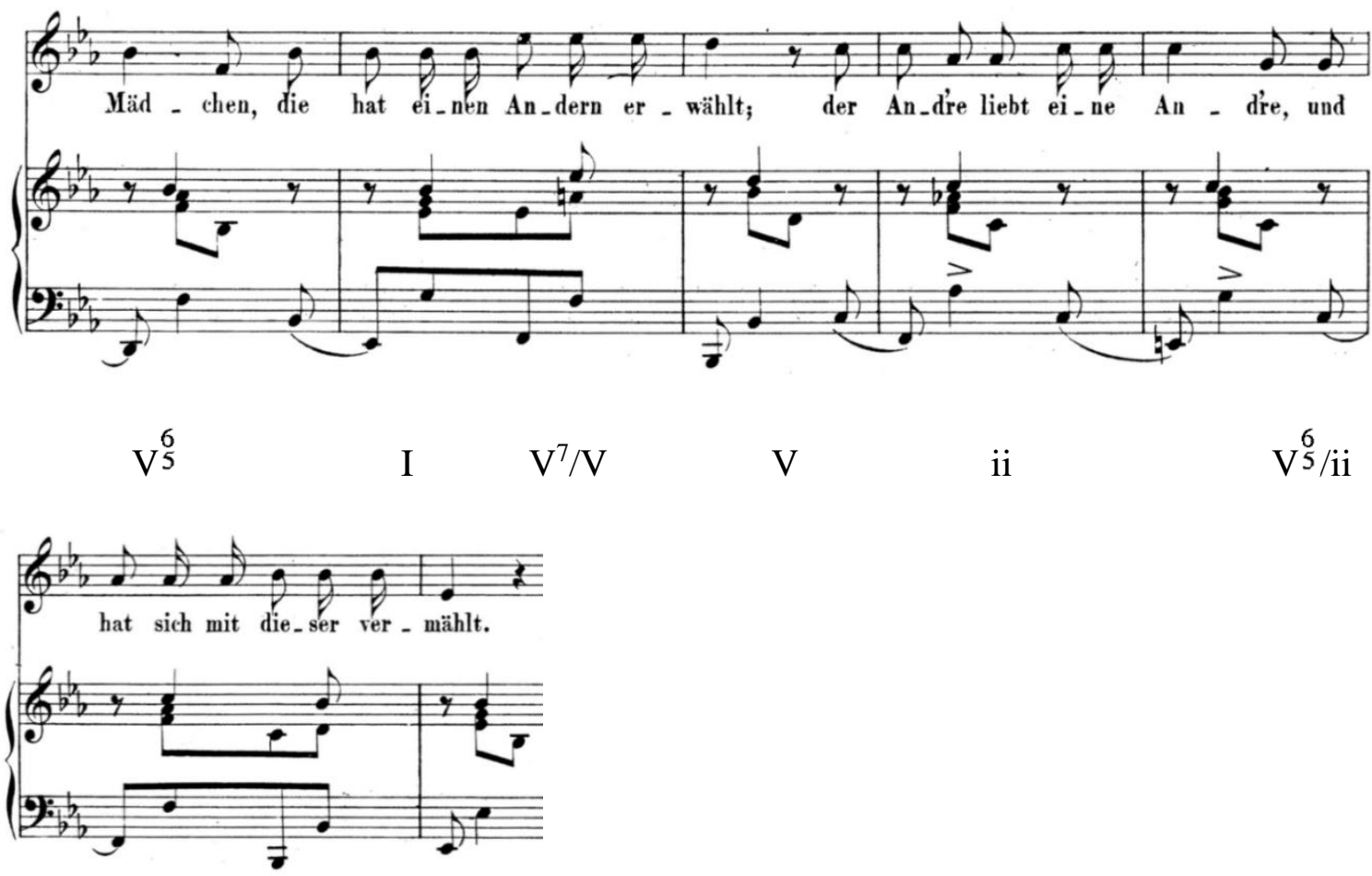

Eb: ii $\quad \mathrm{V} \quad \mathrm{I}$

Figure 5-43. Schumann: "Ein Jüngling liebt ein Mädchen,” mm. 1-12 
Schumann retains the same mood in the piano interlude, with the humorous musical language still adopted, but now moves to the subdominant B-flat. In the second stanza, Heine feels sympathy for the boy who met his beloved by chance and is simultaneously hurt by her. In measures 18 to 20, Schumann particularly emphasizes the words "den ersten, besten Mann" ("The first, best man") by using an ascending harmony, as the minor chords emotionally push forward the expression of the poem. The harmonic tension maximizes the feeling of the boy's disappointment under a dramatic ritardando (see Figure 5-44): 


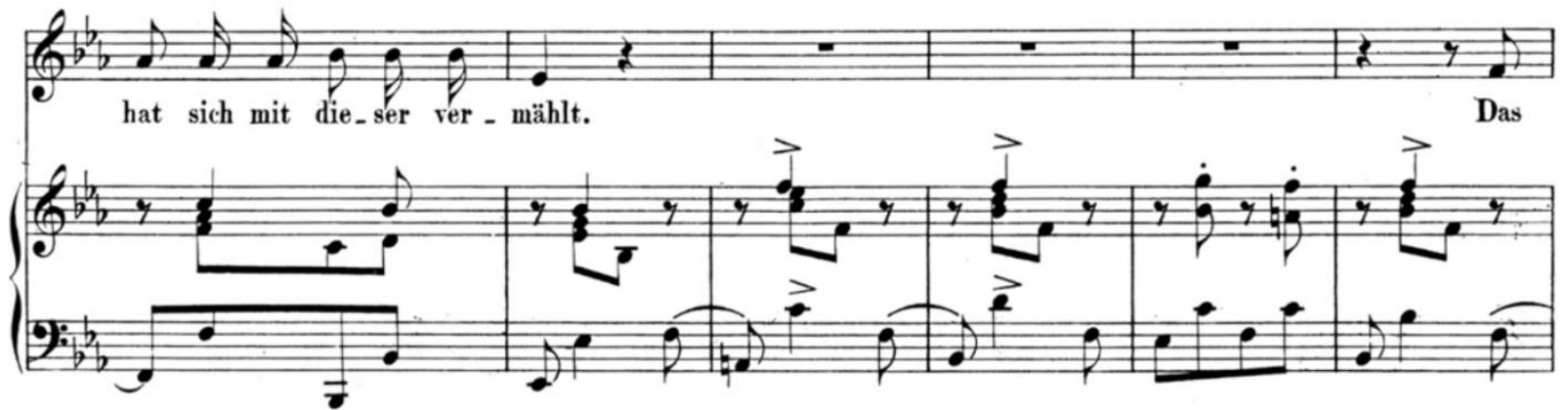

Eb: ii $\quad \mathrm{V} \quad \mathrm{I} \quad \mathrm{V}^{5} / \mathrm{V}$
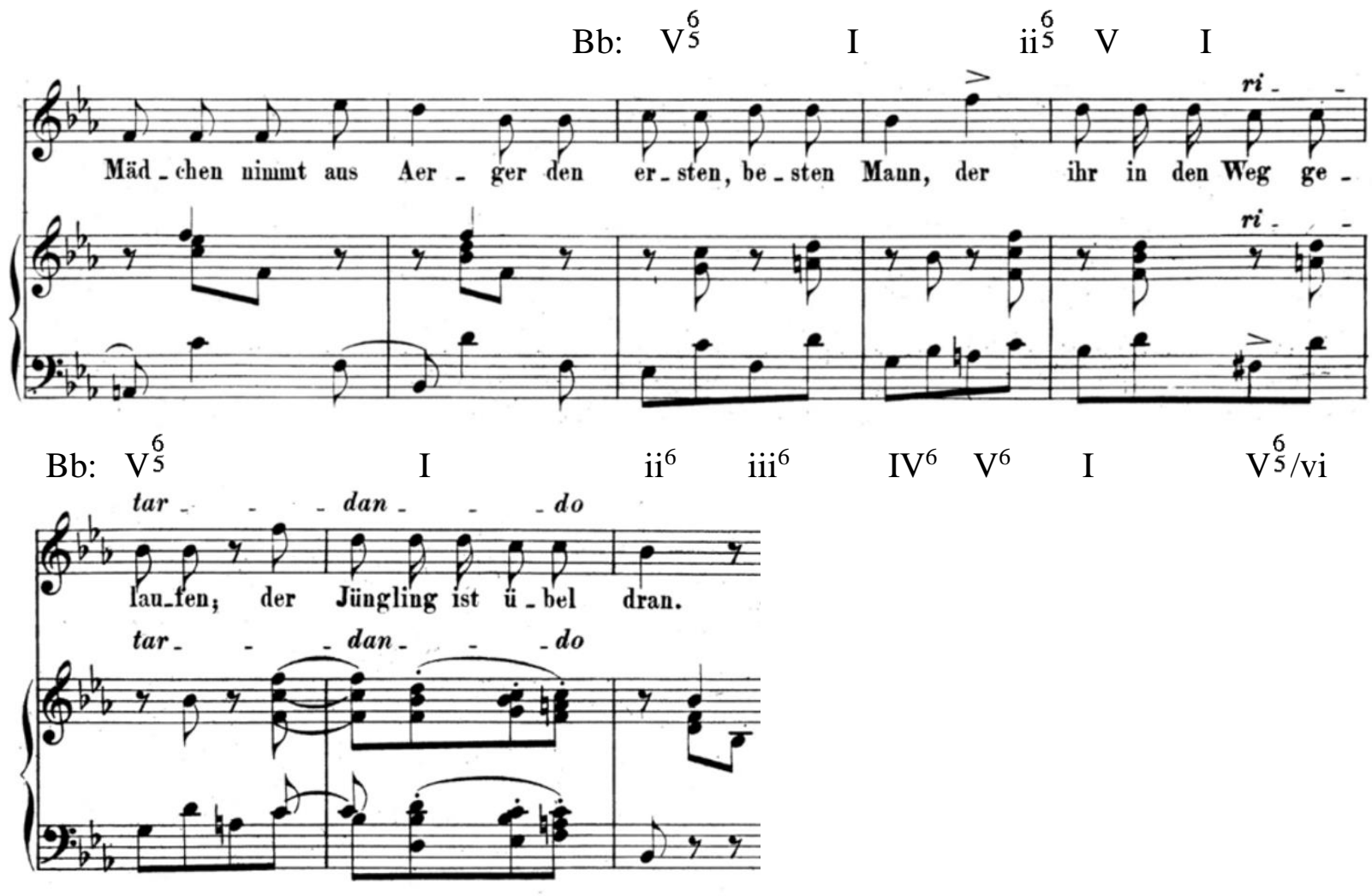

Bb: vi $\quad \mathrm{V}^{6} \quad \mathrm{I}^{6} \quad \mathrm{ii}^{6} \mathrm{~V} \quad \mathrm{I}$

Figure 5-44. Schumann: "Ein Jüngling liebt ein Mädchen,” mm. 11-24

The tonality of Eb returns when Schumann sets the third stanza. However, when Heine writes "und wem sie just passiret," ("and to whom it just now happens,") Schumann chose to apply mode mixture in measure 30 to represent the painful feeling. Heine assumes that whomever experiences such tragic love, his heart will break in two (see Figure 5-45): 


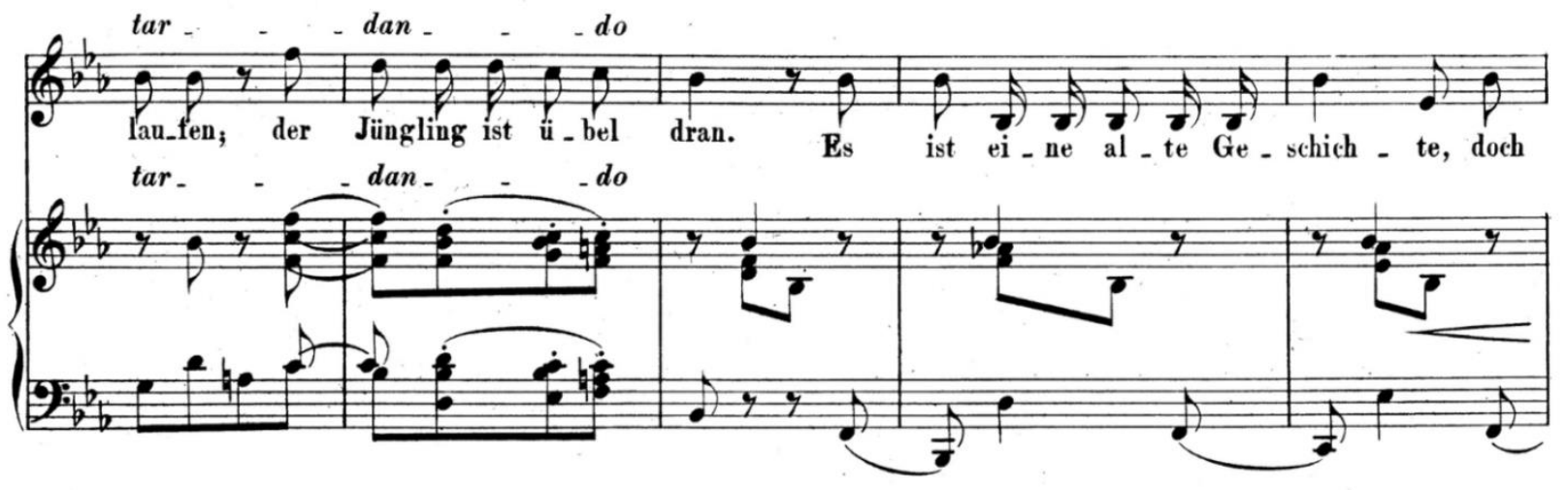

Bb: vi $\quad \mathrm{V}^{6} \quad \mathrm{I}^{6} \quad$ ii $^{6} \mathrm{~V} \quad \mathrm{I}$
Eb: V
$\mathrm{V}^{7}$
$\mathrm{vi}^{7 \text { sus6 }}$
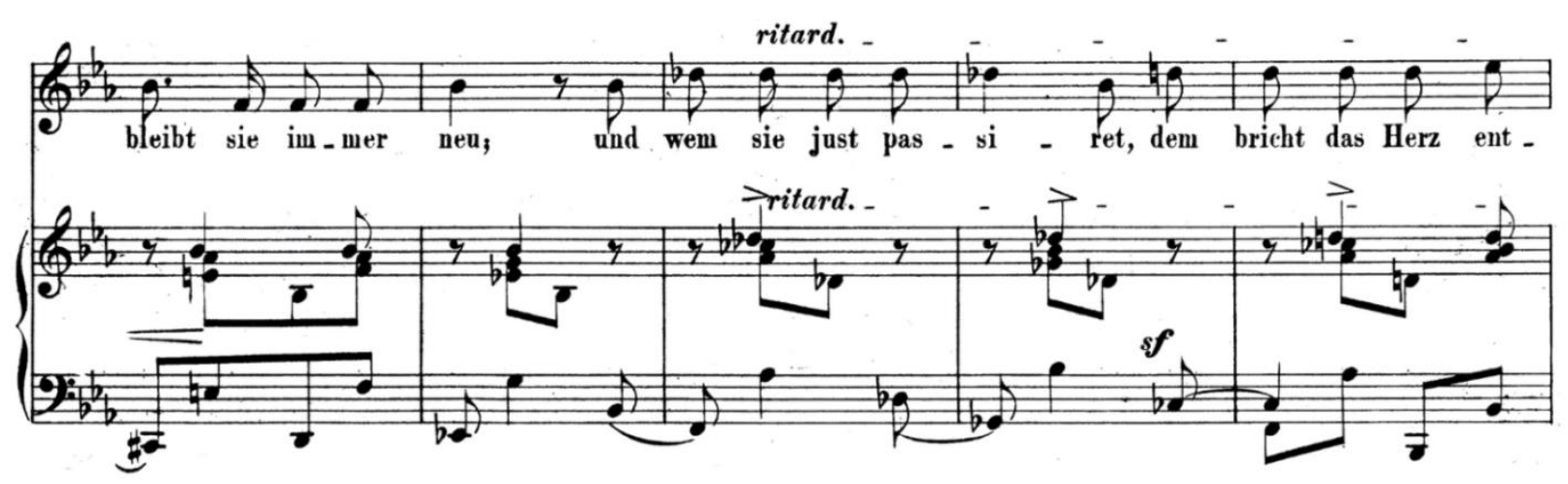

$\begin{array}{lllllll}\mathrm{ct}^{07} & \mathrm{~V}^{5} & \mathrm{I} & \mathrm{V}^{5} / \mathrm{bIII} & \text { bIII } & \mathrm{vii}^{0} & \mathrm{~V}^{7}\end{array}$

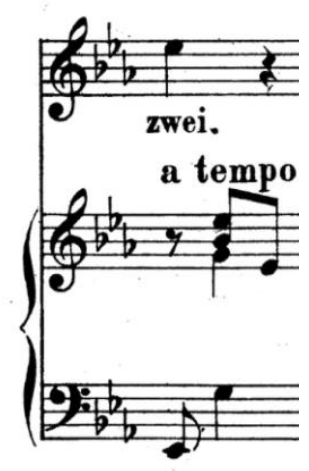

I

Figure 5-45. Schumann: "Ein Jüngling liebt ein Mädchen,” mm. 22-32 
Schumann keeps the humor until the end of the song, which represents that the irony and tragic effect are still felt by people, as Heine says: "Es ist eine alte Geschichte, doch bleibt sie immer neu," ("It is an old story, but it remains ever new,") (see Figure 5-46):

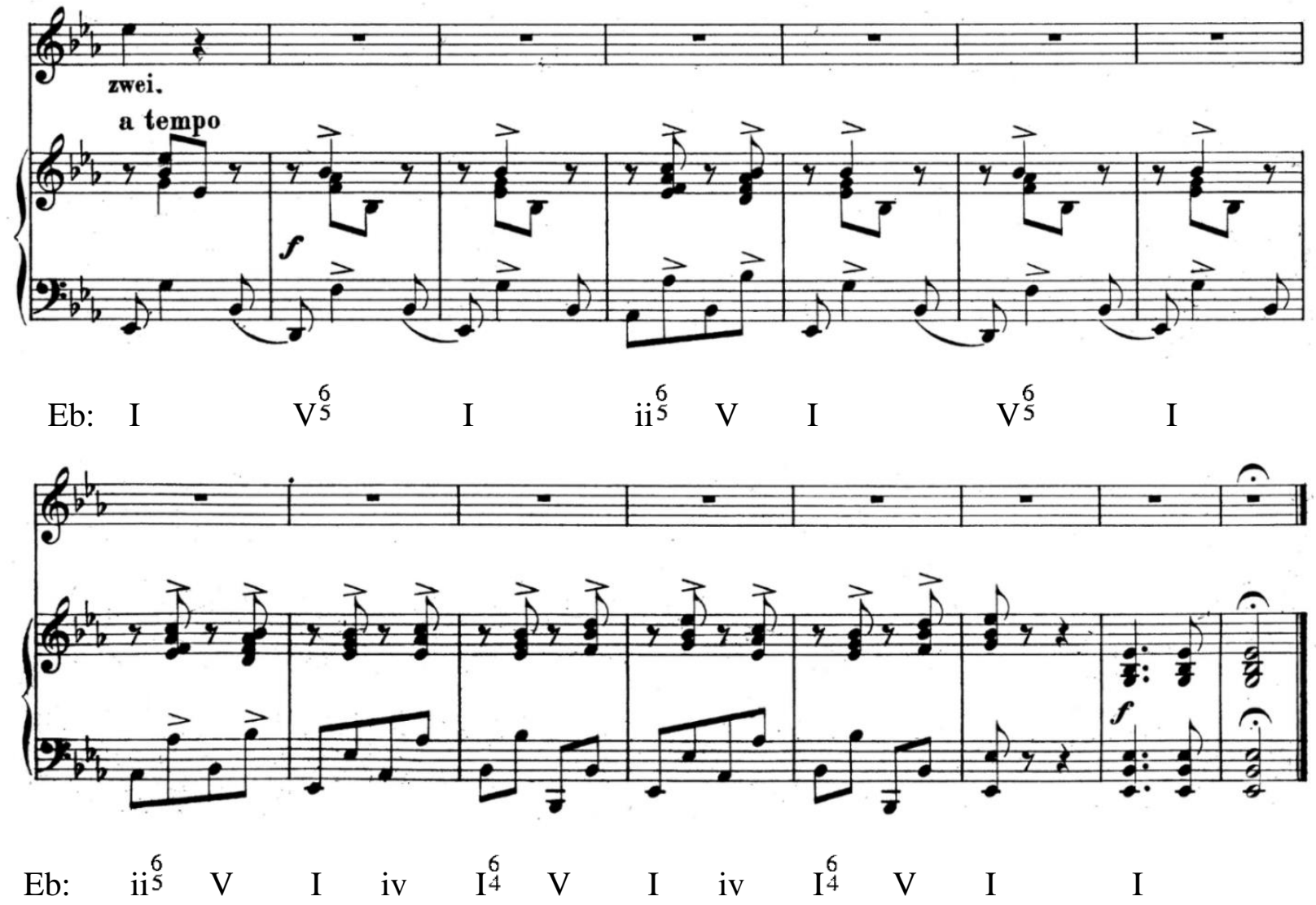

Figure 5-46. Schumann: “Ein Jüngling liebt ein Mädchen,” mm. 32-46

Schumann retains the emphasis on syncopation from the previous "Hör' ich das Liedchen klingen," but here it is used in a different character. In "Ein Jüngling liebt ein Mädchen,"

Schumann adopts a folk-song quality to represent the familiar subject matter, a common situation in matters of love. Schuman also uses an extensive postlude as in the previous song. Here the slurs, off-beat accents and left-hand leaps represent not only challenges for the pianist to continue in rhythm and retain the mood through the long passage, but also Schumann using 
humorous musical elements for the purpose of the tragic effect of the poem. It is challenging for the pianist and singer to effectively communicate the irony of this song, and for the pianist to communicate this character through the extended postlude. 


\section{Am leuchtenden Sommermorgen}

Am leuchtenden Sommermorgen

geh' ich im Garten herum.

Es flüstern und sprechen die Blumen, ich aber wandle stumm.

Es flüstern und sprechen die Blumen und schau'n mitleidig mich an:

Sei unserer Schwester nicht böse, du trauriger blasser Mann!
On a radiant summer morning

I go walking in the garden.

The flowers are whispering and speaking, But I wander about in silence.

The flowers are whispering and speaking And looking at me sympathetically, saying: Do not be angry with our sister, You pale, unhappy man. ${ }^{76}$

Key: Bb major

Form: Modified strophic

Accompanying Style: Layered writing, arpeggiated inner voice

Predominant Characteristics of Vocal Line: Triadic outlines, repeated notes

In this poem, Heine initially describes a bright summer morning and uses flowers as the medium to convey the main purpose of the poem, which is the healing idea of forgiveness. Heine borrows the quiet tone of the flowers to perform a self-mockery of the poet. Schumann applies the descending arpeggiated figure as a predominant accompaniment feature in this song, which is also a significant feature in the tenth song "Hör' ich das Liedchen klingen." In addition, in the first song of the cycle, Schumann also applied the arpeggiated figure with sixteenth notes, but in an ascending direction. Schumann uses a cantabile melody in the upper voice of the piano with syncopation and continuously applies syncopation in song 10 "Hör' ich das Liedchen klingen," song 11 "Ein Jüngling liebt ein Mädchen,” and song 12 “Am leuchtenden Sommermorgen” each with distinct approaches for representing a shift of three extreme emotions in sequence, from the memory of grief to jealous despair for being spurned and lastly a move to forgiveness.

\footnotetext{
${ }^{76}$ Glass, Beaumont, Schumann's complete song texts. (Genesco, NY: Leyerle Publications, 2002). 69-70.
} 
Schumann begins the two-measure introduction, marked Ziemlich langsam (somewhat slowly), with a dramatic German augmented sixth chord and an unexpected resolution which indicates the specialty of the song. Schumann begins with this surprising harmony which emphasizes another mood change and the new idea of forgiveness (see Figure 5-47):

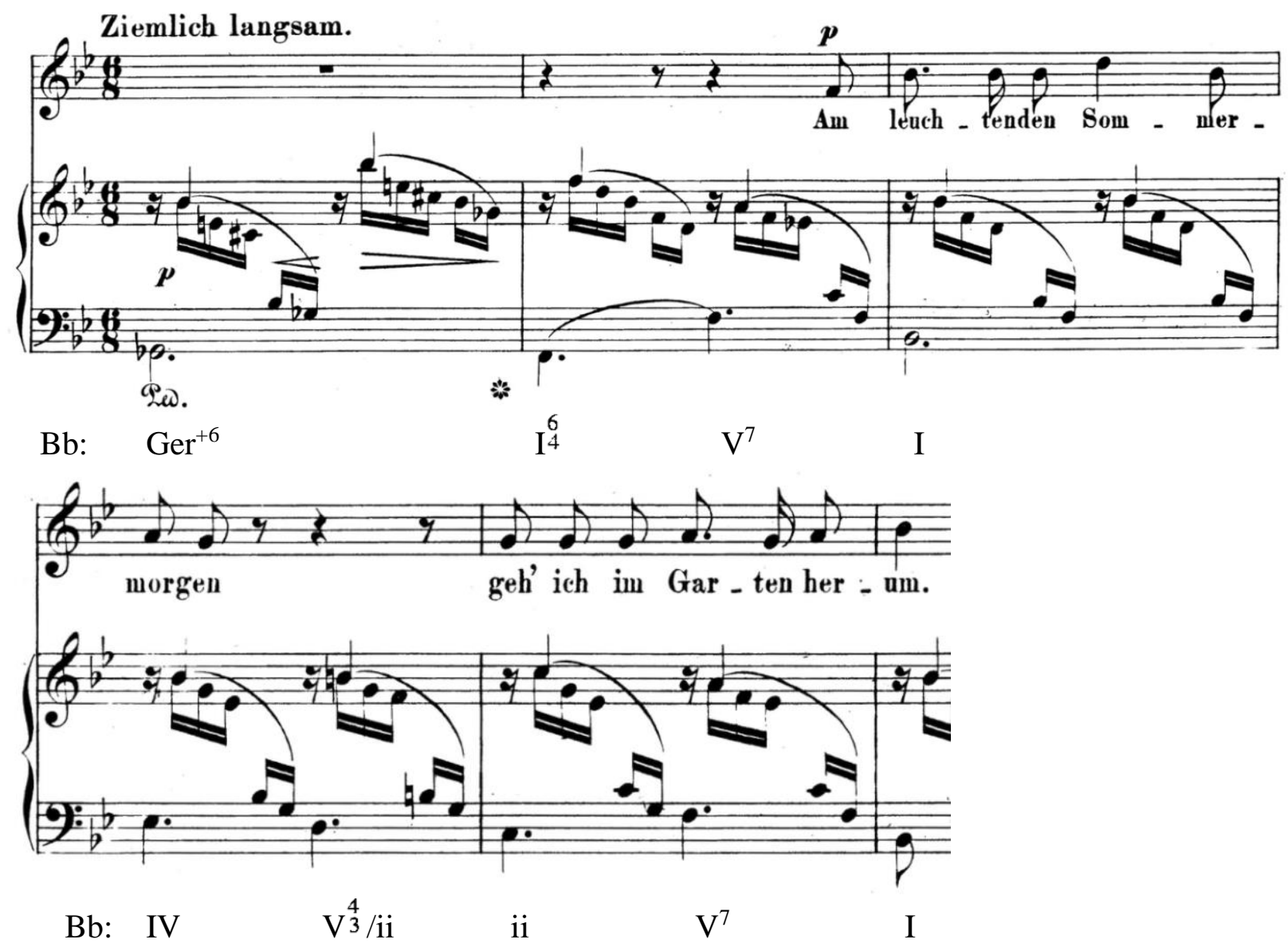

Figure 5-47. Schumann: “Am leuchtenden Sommermorgen” mm. 1-6

After repeating the introduction as an interlude in measures 6 and 7, Schuman uses interesting enharmonic spellings in the voice and the piano in measures 8 through 10 . His use of the German augmented sixth chords to quickly move between keys enriches the implication of 
the poem, as the poet imagines the flowers are talking a great deal to him, but he wanders in silence (see Figure 5-48):
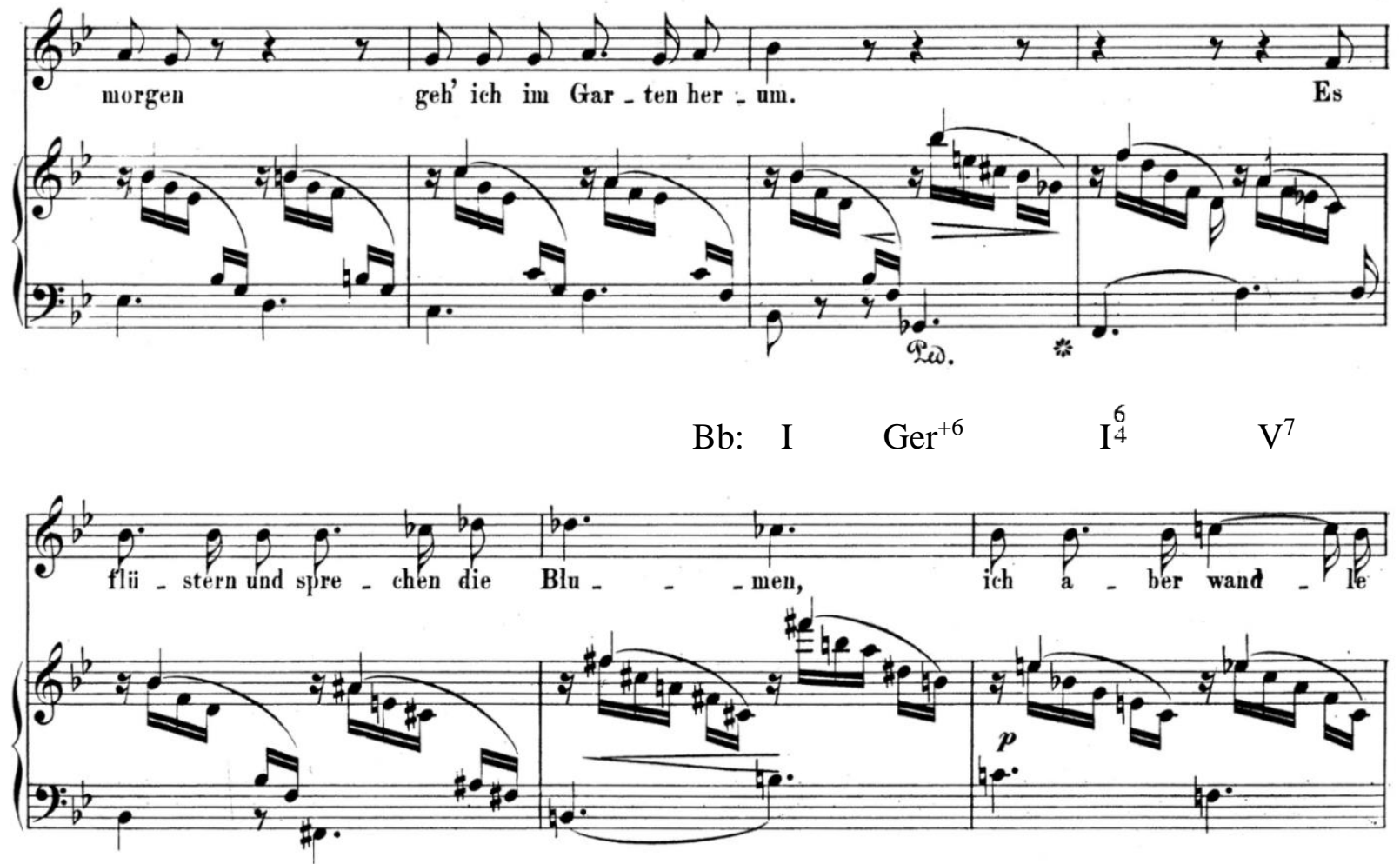

$\begin{array}{lllll}\mathrm{Bb} & \mathrm{I} & \mathrm{Ger}^{+6} & \mathrm{~V}^{7} / \mathrm{V} & \mathrm{V}^{7}\end{array}$
$\mathrm{E}: \mathrm{V}^{7} / \mathrm{V}$
ii
$\mathrm{V}^{7}$
$\mathrm{Ger}^{+6}$

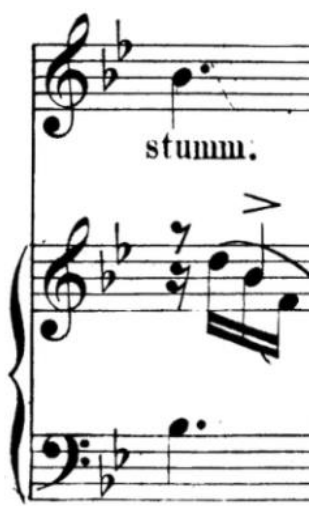

$\mathrm{Bb}: \quad \mathrm{I}$

Figure 5-48. Schumann: “Am leuchtenden Sommermorgen” mm. 4-11 
In the second stanza, Heine repeats the sentence of "Es flüstern und sprechen die Blumen," ("The flowers are whispering and speaking,") but instead of wandering in silence, the poet speaks of sympathy. Schumann utilizes an unusual passing chromatic chord in measure 16 to heighten the moment and prepare the upcoming slower section. The poet now conveys a new emotion for his beloved, which is forgiveness. Schumann uses a pianissimo dynamic and a new tempo Langsamer (slower) to demonstrate how sad and pale the poet is (see Figure 5-49):

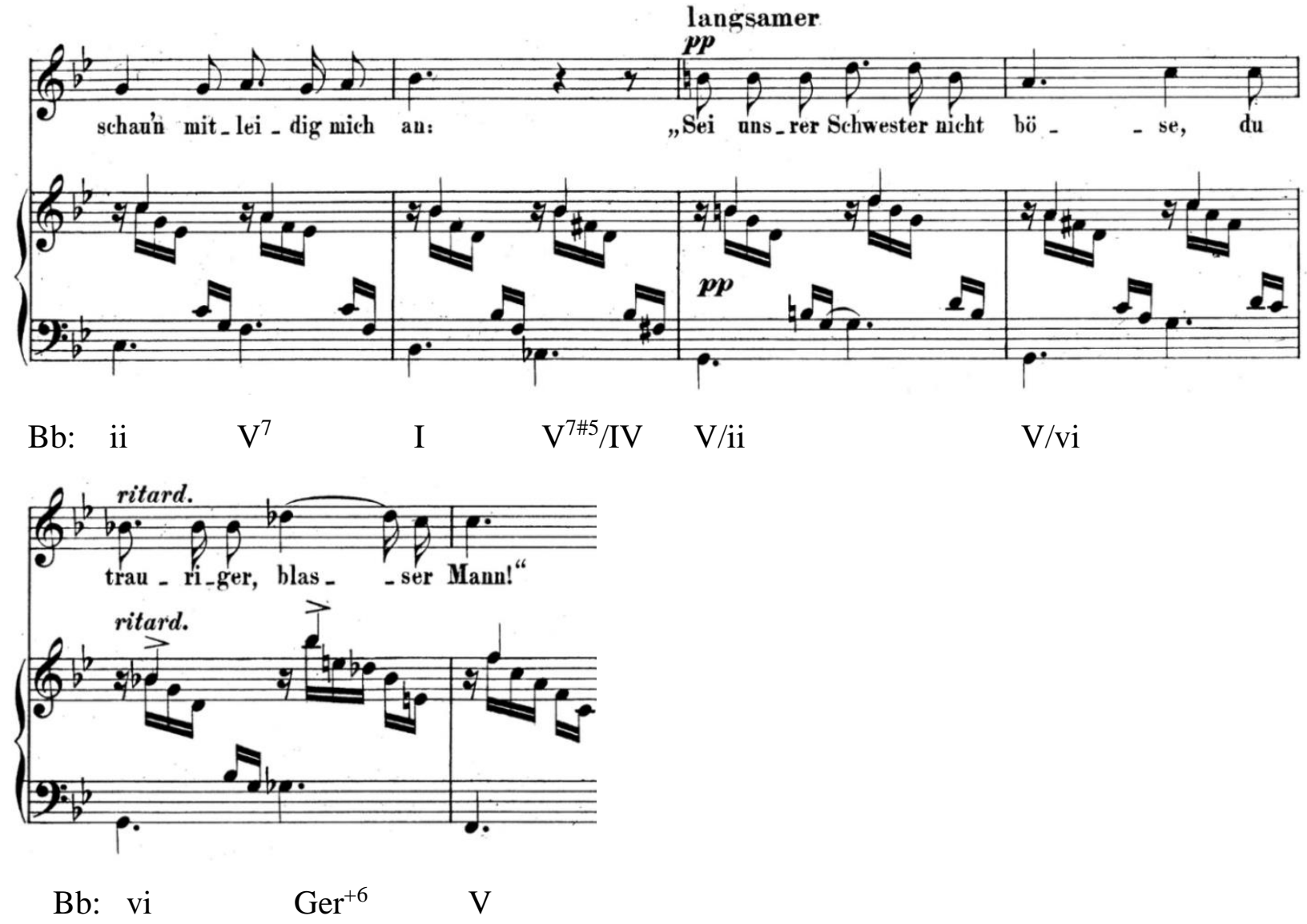

Figure 5-49. Schumann: “Am leuchtenden Sommermorgen” mm. 15-20

The slow and steady descending arpeggiated figure continues after the last word until measure 23, then Schumann sustains the top melody as in the tenth song "Hör' ich das Liedchen 
klingen." The postlude is a lengthy piano solo as in the previous two songs and foreshadows "the final message as the music moves from forgiveness through reconciliation to undying love." ${ }^{77}$ The tremendously beautiful C-D-Eb-F melody, repeated twice in the postlude, will be heard again in the postlude of the last song "Die alten, bösen Lieder." In measures 23 to 26, there are three chromatic harmonies in a row to enrich the beauty of the song, especially the distinct harmony vii $^{4}{ }_{3}^{4} / \mathrm{ii}$ in measure 24 on which Schumann emphasizes it with a curious symbol of crescendo and diminuendo. Schumann applies the special symbol to indicate that the pianist should play softly after the top melody $\mathrm{F}$ then stress the chord vii $^{0_{3}^{4}} / \mathrm{ii}$ and immediately release the power by playing softly, a kind of accent on the chord. In the last two bars, Schumann sustains the different pitches to symbolize the poet's undying love even though he was rejected by his beloved. In the last four bars, the overall descending line represents that the expression of hatred fades away as eventually the poet forgives his beloved (see Figure 5-50):

\footnotetext{
77 Sams, Eric, "The Songs," in The Songs of Robert Schumann. (Bloomington and Indianapolis: Indiana University Press, 1993). 119.
} 

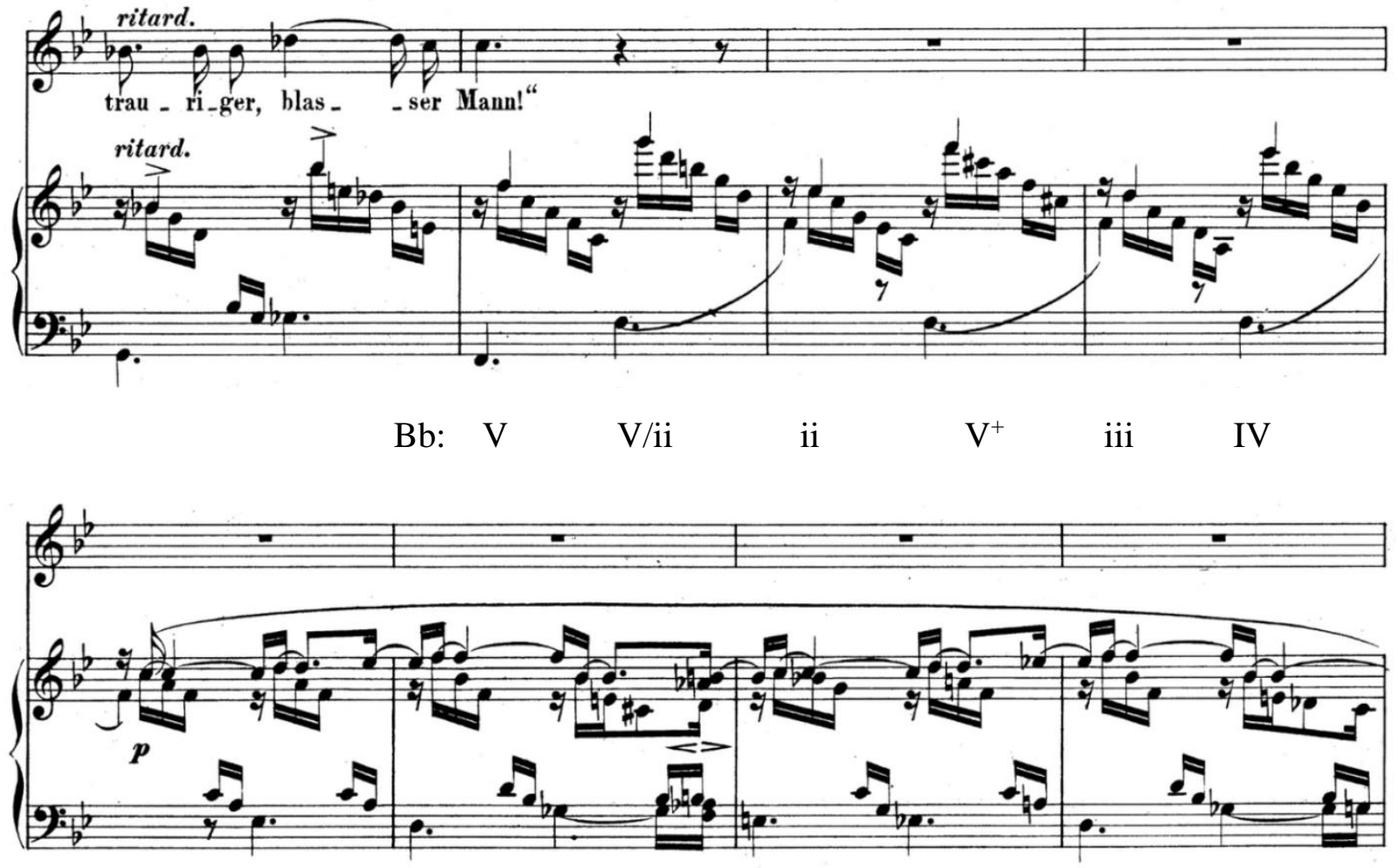

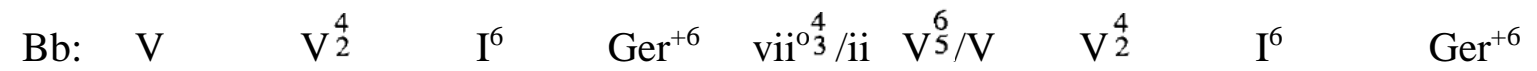

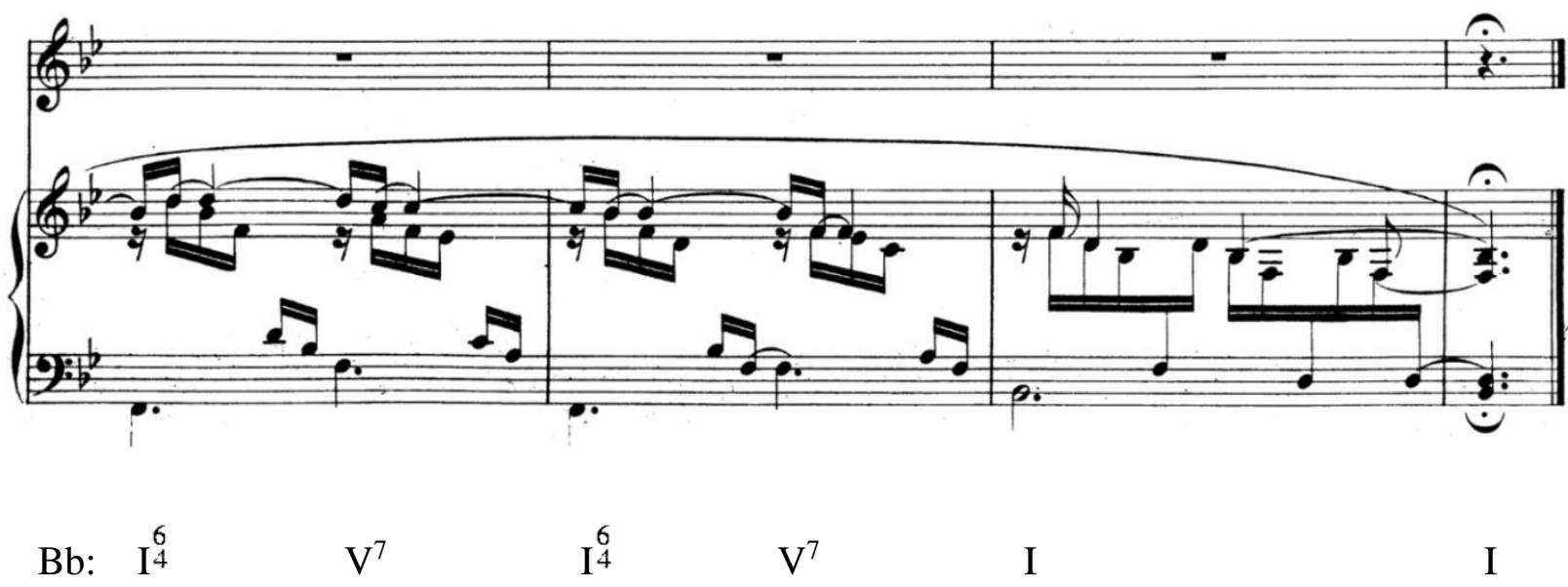

Figure 5-50. Schumann: “Am leuchtenden Sommermorgen” mm. 19-30

One of the fascinating characteristics of this song is Schumann's use of the German augmented sixth chord which he uses seven times to heighten the expression. In addition, the 
"ambiguous relation of voice to instrument is crucial to Schumann's technique."78 When the voice enters in measure 3 , the predominant status of the piano changes, and the graceful vocal melody takes the lead while the piano accompanies it with a consistent rhythmic pattern and layered writing. Once again Schumann uses the arpeggiated figures in the piano to represent the delicate presence and movement of the flowers. The technical challenge for pianists before measure 23 is similar to "Hör' ich das Liedchen klingen," highlighting the top melody in the right hand with while playing the middle notes softly, especially when the piano presents itself in the interludes. In measure 23, the piano takes over the melody, and the pianist must capture the emotional intensity with the same principle until the end.

${ }^{78}$ Rosen, Charles, "Fragments," in The Romantic Generation. (Cambridge, Massachusetts: Harvard University Press, 1998), 46. 


\section{Ich hab' im Traum geweinet.}

Ich hab' im Traum geweinet. Mir träumte, du lägest im Grab. Ich wachte auf, und die Thräne Floss noch von der Wange herab.

Ich hab' im Traum geweinet. Mir träumt', du verliessest mich. Ich wachte auf, und ich weinte Noch lange bitterlich.

Ich hab' im Traum geweinet, Mir träumte, du wärst mir noch gut. Ich wachte auf und noch immer Strömt meine Thränenfluth.
I was weeping in my dream. I dreamt that you were lying in your grave. I woke up, and my tears were Still flowing down my cheeks.

I was weeping in my dream. I dreamt that you were leaving me. I woke up, and I still wept Bitterly for a long time.

I was weeping in my dream. I dreamt that you still loved me. I woke up, and my tears are Streaming still-in a veritable flood. ${ }^{79}$

Key: E-flat minor

Form: Modified strophic

Accompanying Style: Chordal

Predominant Characteristics of Vocal Line: Repeated notes, narrow range

Heine depicts dream and reality for the context of "Ich hab' im Traum geweinet" ("I was weeping in my dream,"), and the poet is overcome with weeping in these two dimensions. Heine uses three stanzas to represent the difference of each dream, "only the second dream reflects present reality; the first is of the future, and the third is a memory of what is irrevocably past, ${ }^{\prime 80}$ and Schumann uses four tonalities to represent the complex emotions. Moreover, Schumann alternates between voice and piano for the first two stanzas, a technique he has not used in previous songs. By the last stanza, the voice is synchronized with the piano, and the song reaches the most painful moment.

\footnotetext{
79 Glass, Beaumont, Schumann's complete song texts. (Genesco, NY: Leyerle Publications, 2002). 70.

${ }^{80}$ Rosen, Charles, "Mountains and Song Cycles," in The Romantic Generation. (Cambridge, Massachusetts: Harvard University Press, 1998), 205.
} 
Schumann uses a recitative-like singing voice to begin with a Leise (quiet) mood in the key of E-flat minor. The repetitive notes in the vocal line suggest the depressive mood of the poet which also happened in the fourth song "Wenn ich in deine Augen seh."” The piano responds in a low register with a staccato articulation representing the tear drops. This alternating pattern continues within the first two stanzas, and both stanzas are musically identical. Schumann abruptly modulates to C-flat major in measure four, as the poet dreams his beloved was lying in her own grave perhaps at peace. Then in measures 6 , the piano echoes a fragment of the vocal melody. To symbolize the poet waking up from his dream, Schumann uses an augmented triad to depict the words "Ich wachte auf" ("I woke up,") as a sudden jolt into reality. As the poet realizes his tears are still flowing, Schumann returns to the opening key (see Figure 5-51): 


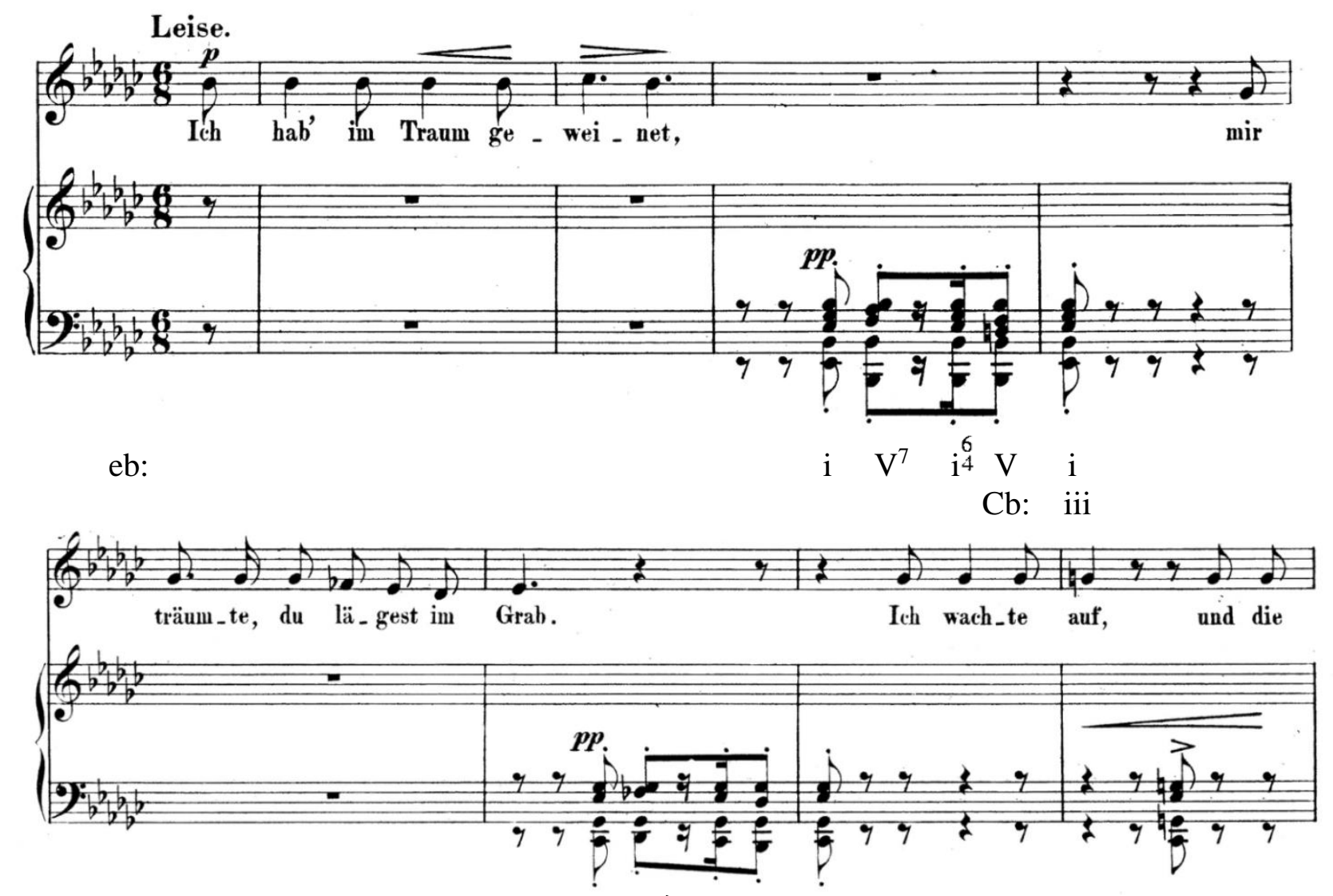

$\mathrm{Cb}: \quad \mathrm{I} \mathrm{V}^{4} \quad \mathrm{I}^{4} \mathrm{~V}^{6}$

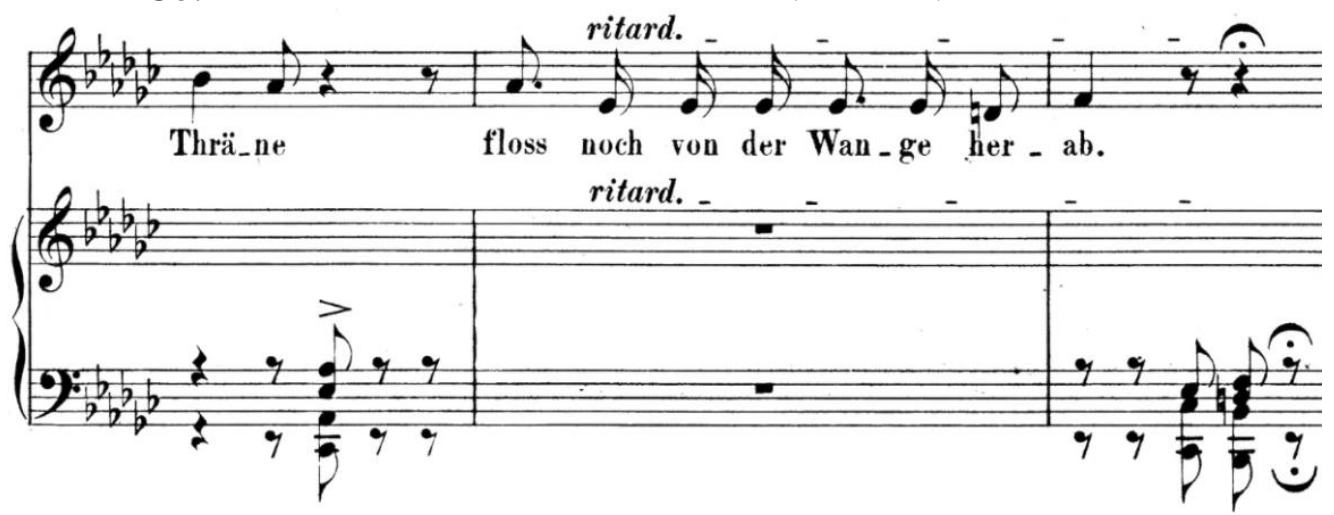

Cb: $\quad \operatorname{vi}^{6}$

eb: $\quad$ iv $^{6} \quad \mathrm{~V}$

Figure 5-51. Schumann: “Ich hab' im Traum geweinet.” mm. 1-11

During the interlude, Schumann has the piano play the melody for the first time in measures 23 and 24, then the voice repeats the melody precisely. The sadness is abruptly replaced by the brief wishful thinking in measure 27: "Mir träumte, du wärst mir noch gut." ("I 
dreamt that you still loved me.") The C-natural indicates the stability of D-flat major. As the poet again awakes, Schumann modulates to Ab minor, depicting tears that flow as fiercely as the unusual non-functional chromatic chords in measures 29 and 30 . While the piano plays sustained chromatic harmonies, the voice sings a repeated D-flat (see Figure 5-52): 


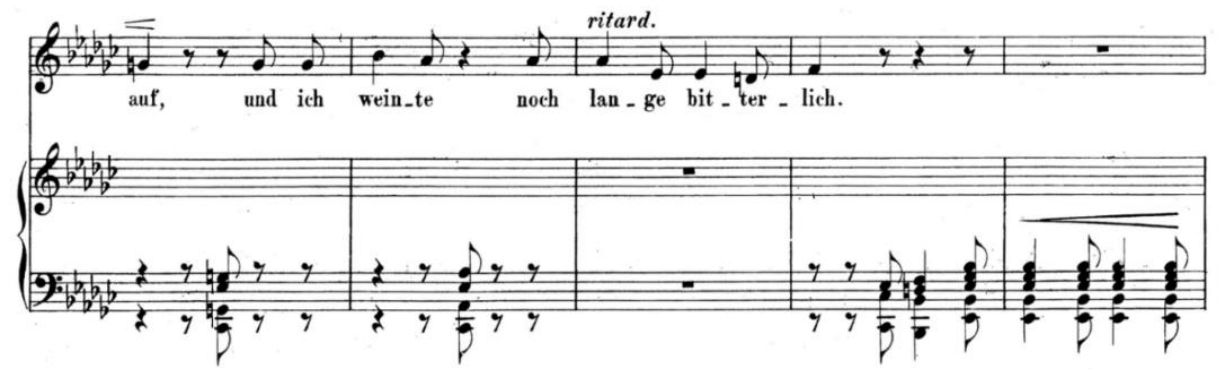

Cb: $\quad \mathrm{I}^{+} \quad \mathrm{vi}^{6}$

$$
\text { eb: } \quad \text { iv }{ }^{6} \quad \text { V } \quad \text { i } \quad \text { i }
$$

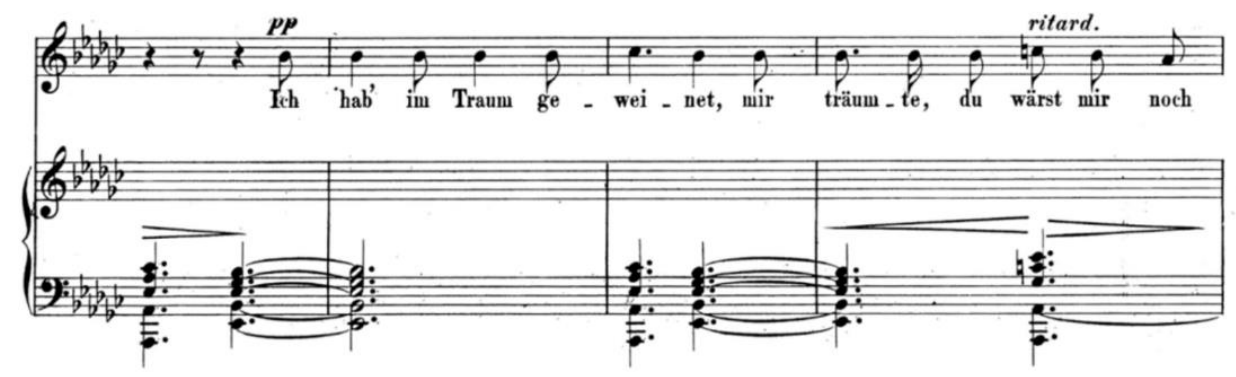

eb: iv i iv i i

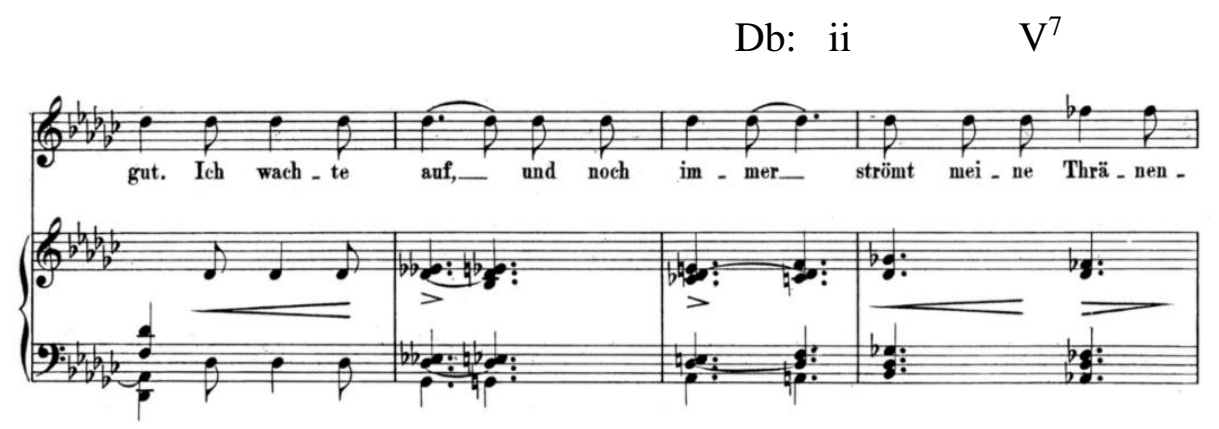

Db: I

$\mathrm{IV}^{6}$

$\mathrm{ab}: \mathrm{V}^{6} / \mathrm{III} \quad \mathrm{iv}^{6}$

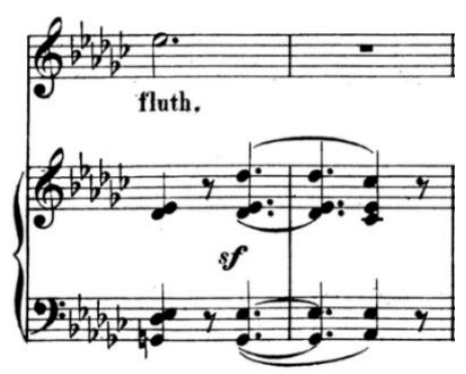

$\mathrm{ab}: \mathrm{V}^{6} \quad \mathrm{i}$

Figure 5-52. Schumann: "Ich hab' im Traum geweinet." mm. 20-33 
At the end of the song, the Sforzando in the piano represents a startling gesture, which describes the poet's situation of waking up from the dream. Schumann releases the dramatic tension and resolves to $\mathrm{Ab}$ minor in measure 33 which links the return to $\mathrm{Eb}$ minor. Throughout the song, Schumann took advantage of a great number of rests to create dramatic silences. In measure 34, Schumann includes a grand pause in the postlude, where the voice and piano are silent for an entire measure. This is not used anywhere else in the cycle. He then repeats the same accompanying material from measure three representing the continued tear drops and unresolved sadness of the poet (see Figure 5-53):

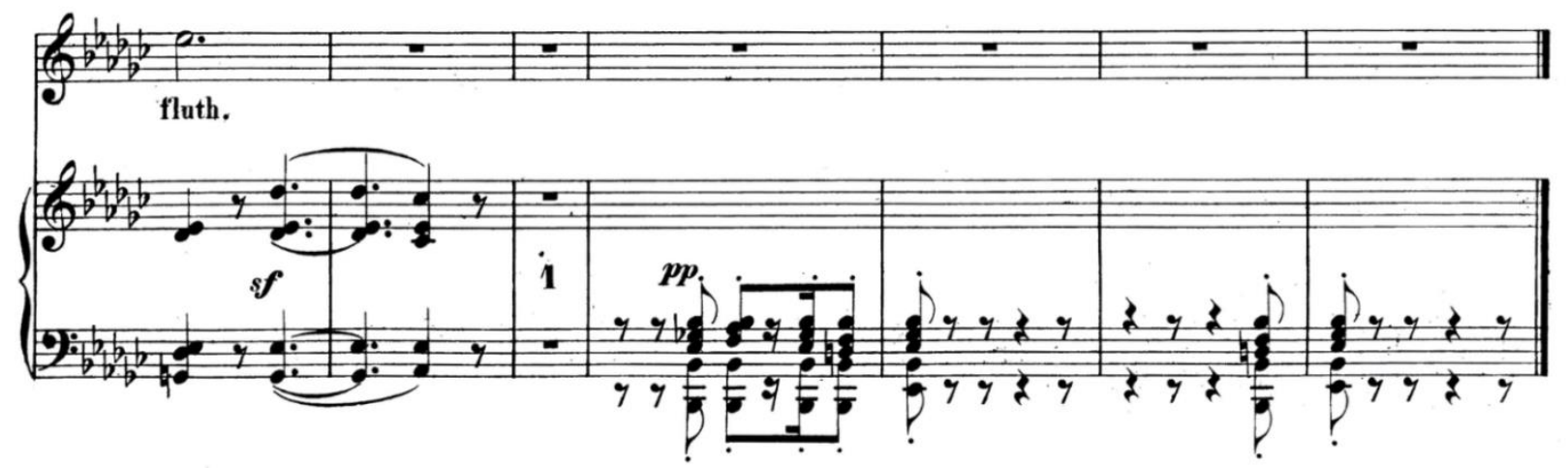

ab: $\mathrm{V}^{6} \mathrm{i}$
eb: iv
$\mathrm{i}^{6} \mathrm{~V}^{7} \stackrel{\mathrm{i}^{4}}{4} \mathrm{~V} \quad \mathrm{I}$
V I

Figure 5-53. Schumann: “Ich hab’ im Traum geweinet.” Mm. 32-38

In "Ich hab' im Traum geweinet," Schumann creates a bleak dialogue between the voice and the piano. He focuses mostly on one pitch in the voice to represent the despair of the poet. The piano accompaniment of gradually complex chromatic chordal changes also embodies the increasingly depressive mood. In striking contrast to the previous songs, the song's texture and stark character are new and unequalled in the cycle. 


\section{Allnächtlich im Traume seh' ich dich,}

Allnächtlich im Traume seh' ich dich, und sehe dich freundlich grüssen, und laut aufweinedn stürz' ich mich zu deinen süssen Füssen.

Du siehest mich an wehmüthiglich, und schüttelst das blonde Köpfchen; aus deinen Augen schleichen sich die Perlenthränentröpfchen.

Du sagst mir Heimlich ein leises Wort, und gibst mir den Strauss von Cypressen, ich wache auf, und der Strauss ist fort und's Wort hab ich vergessen.

Key: B major

Form: Modified strophic

Accompanying Style: Chordal, syncopated

Predominant Characteristics of Vocal Line: Downward leaps, wide range

Schumann continues the focus on dreams in "Allnächtlich im Traume seh' ich dich," (“Every night I see you in my dreams,"). In song 13, the poet was weeping, lost in both dreams and reality; however, in this song, the poet moves from dark despair to an imaginary longing of both himself and the beloved. Schuman creates the opening melody with short melodic fragments which creates a wistful character for the song.

Schumann uses B major to change the mood from the previous song. This is the third song in which Schumann did not write a tempo marking. Schumann uses no introduction here and has the vocal line enter directly with the piano, a technique he also used in the second song “Aus meinen Tränen sprießen.” Schumann utilizes the first four measures as a phrase but

\footnotetext{
${ }^{81}$ Glass, Beaumont, Schumann's complete song texts. (Genesco, NY: Leyerle Publications, 2002). 71.
} 
combines three fragments. He then duplicates essentially the identical material in the second four measures. In measure nine, Schumann suddenly switches to triple meter and uses a chromatic harmony to stress the moment of "laut aufweinend;" ("weeps loudly;") then he wants to be close to her, even down at her feet. In measure 11, when the poet says "Füssen," ("feet,") Schumann uses a descending line in the vocal part, the lowest point of the song. Schumann applies a twomeasure interlude as a bridge to the second stanza (see Figure 5-54): 


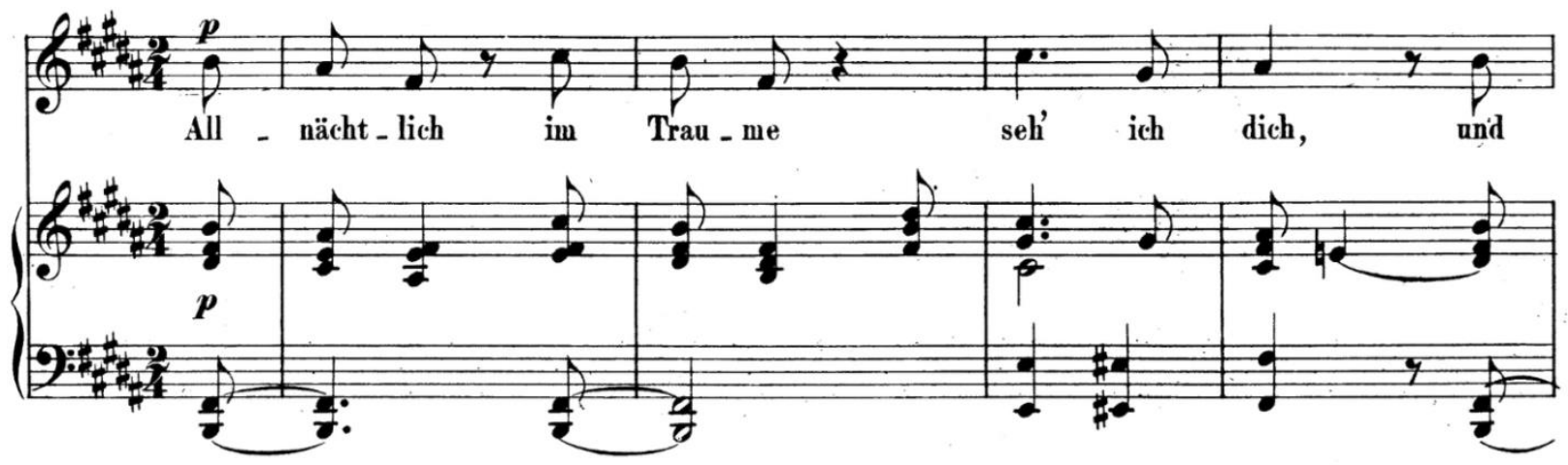

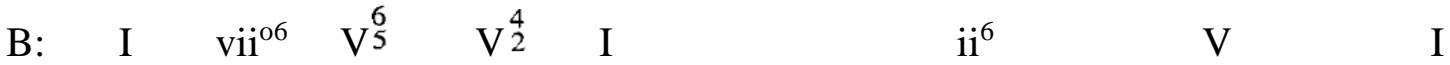

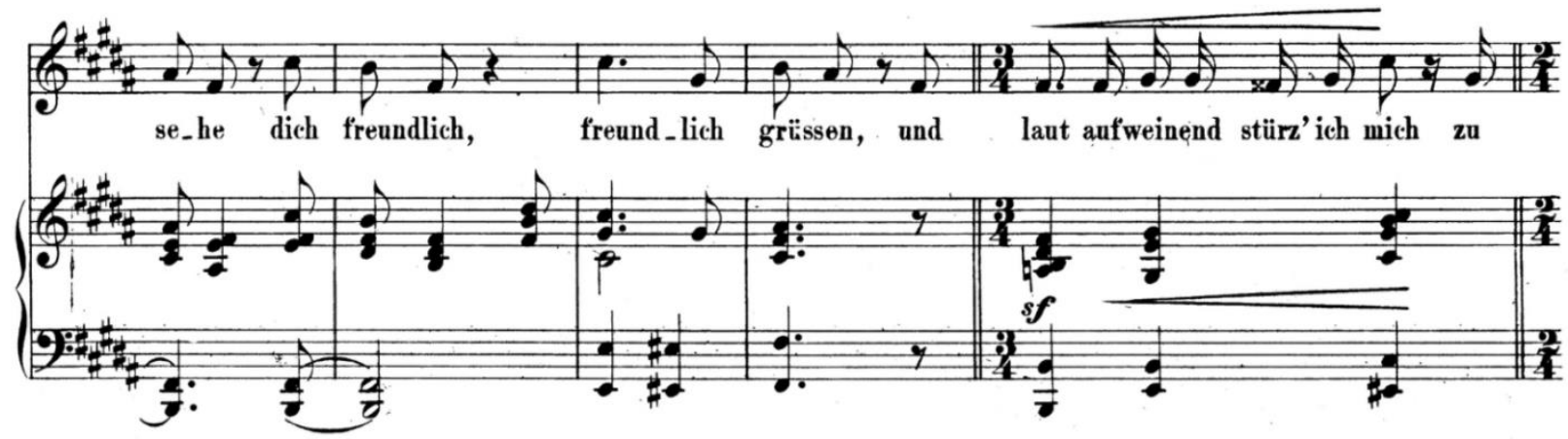
B: $\operatorname{vii}^{06} \mathrm{~V}^{6} \mathrm{~V}^{4} \mathrm{I}$
ii $^{6}$
V
$\mathrm{V}^{7} / \mathrm{IV} \quad$ IV
$\mathrm{V}^{5} / \mathrm{V}$

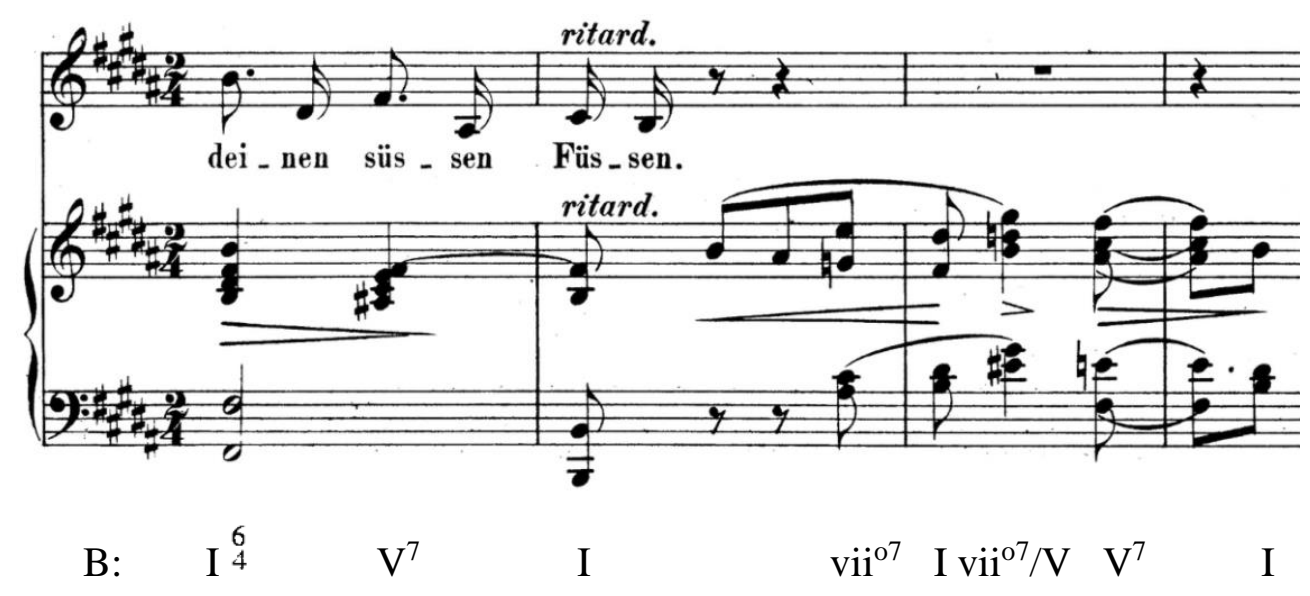

Figure 5-54. Schumann: “Allnächtlich im Traume seh' ich dich,” mm. 1-13

In the third stanza, Schumann still adopts the same use of fragments as the first two stanzas even though the vocal line changes slightly, and the dynamic is distinguished from the first two stanzas as Schumann uses a pianissimo to reflect the text "Du sagst mir Heimlich ein 
leises Wort," ("You secretly tell me a soft word,"). In measure 36, Schumann uses a new harmony V/vi, which not only extends the last phrase, but also represents the reluctant emotion of the phrase "Strauss ist fort" ("spray is gone"). The last three chords act as an echo as the poet wishes to remember the soft word that she told him in the dream. In the last two bars, the voice ends on the dominant F-sharp pitch, and Schuman resolves to the tonic in the last bar of the piano, a technique he has used in previous songs (see Figure 5-55): 

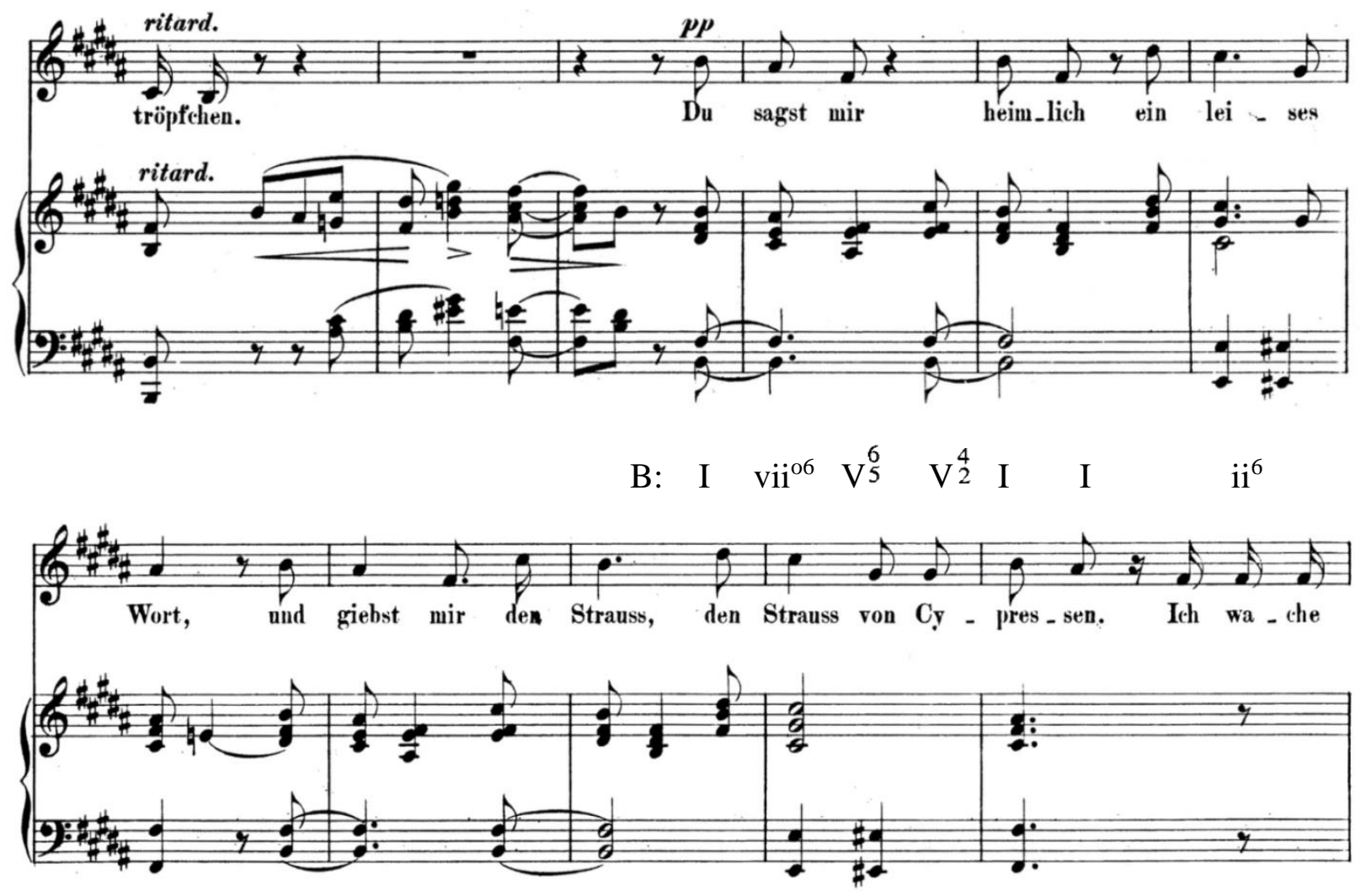
B: $\mathrm{V}$
I $\quad$ vii $^{06} \mathrm{~V}^{6} \quad \mathrm{~V}^{4}$
I
ii $^{6}$
$\mathrm{V}$

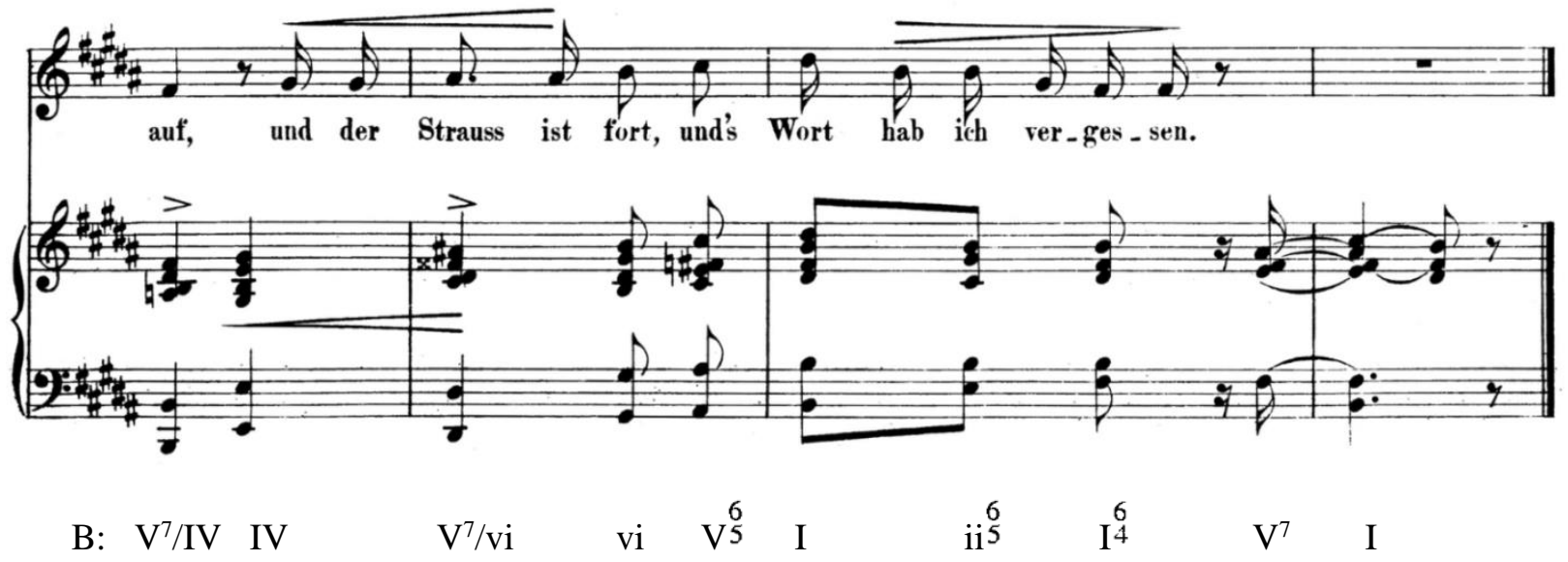

Figure 5-55. Schumann: “Allnächtlich im Traume seh' ich dich,” mm. 24-38

Schumann uses a fragmented melodic approach to represent the poet's wistful memory of his beloved. The piano doubles the melody with the voice, which makes the remembering of the 
beloved deeper, almost like a duet between the two, with the poet believing the beloved feels the same loss. 


\section{Aus alten Märchen winkt es}

Aus alten Märchen winkt es hervor mit weisser Hand, da singt es und da klingt es von einem Zauberland,

wo bunte Blumen blühen im goldnen Abendlicht und lieblich duftend glühen mit braütlichem Gesicht.

Und grüne Bäume singen uralte Melodei'n, die Lüfte heimlich klingen und Vögel schmettern drein

Und Nebelbilder steigen wohl aus der Erd' hervor und tanzen luft'gen Reigen im wunderlichen Chor, und blaue Funken Brennen an jedem Blatt und Reis, und rothe Lichter rennen im irren, wirren Kreis, und laute Quellen brechen aus wildem Marmorstein, und seltsam in den Bächen strahlt fort der Wiederschein.

Ach könnt' ich dorthin kommen und dort mein Herz erfreu'n, und aller Qual entnommen und frei und selig sein!

Ach, jenes Land der Wonne, das seh' ich oft im Traum, doch kommt die Morgensonne, zerfliesst's wie eitel Schaum.
A white hand is beckoning out of Old fairy tales,

There are musical sounds and a song

That tell of an enchanted land,

Where multicolored flowers bloom In the garden evening light And exhaling a lovely fragrance Glow with the face of a bride.

And green trees sing Primeval melodies, The airs secretly sound And birdsong is borne on the breeze

And misty images rise up From the earth And dance airy rounds In the fantastic chorus,

And blue sparks burn On every leaf and twig, And red lights run In the delirious, wild circle,

And noisy springs break Out of wild marble rock, And strange reflections Gleam in the brooks.

Ah if only I could go there And gladden my heart, And be free and blissful Relieved of all torment!

Ah, I often see that Land of rapture in my dreams, But when the morning sun appears, It melts away like empty foam. ${ }^{82}$

\footnotetext{
${ }^{82}$ Glass, Beaumont, Schumann's complete song texts. (Genesco, NY: Leyerle Publications, 2002). 72-3.
} 
Key: E major

Form: Through-composed

Accompanying Style: Chordal

Predominant Characteristics of Vocal Line: Wide range, stepwise combined with triadic outline

In this longest song in the cycle, Heine carefully describes an enchanted land containing beautiful sceneries with flowers, trees, birdsong, springs, marble, and brooks. Everything in this idyllic place is free and blissful and sorrows and torments do not exist. Once again, the poet imagines this in his dreams and when he awakes, it vanishes like foam. Schumann uses a 6/8 meter and lilting rhythm to depict this place of joy and happiness and an eight-measure introduction with the marking of Lebendig (Lively) to create the magical image.

“Aus alten Märchen winkt es” and song 2 “Aus meinen Tränen sprießen” are the only two songs in the entire cycle which Schumann begins in the treble clef for both hands. In this song, he uses the higher register to symbolize the magical land which is filled with clear birdsongs, bright landscape, and a lightness of mood (see Figure5-56): 

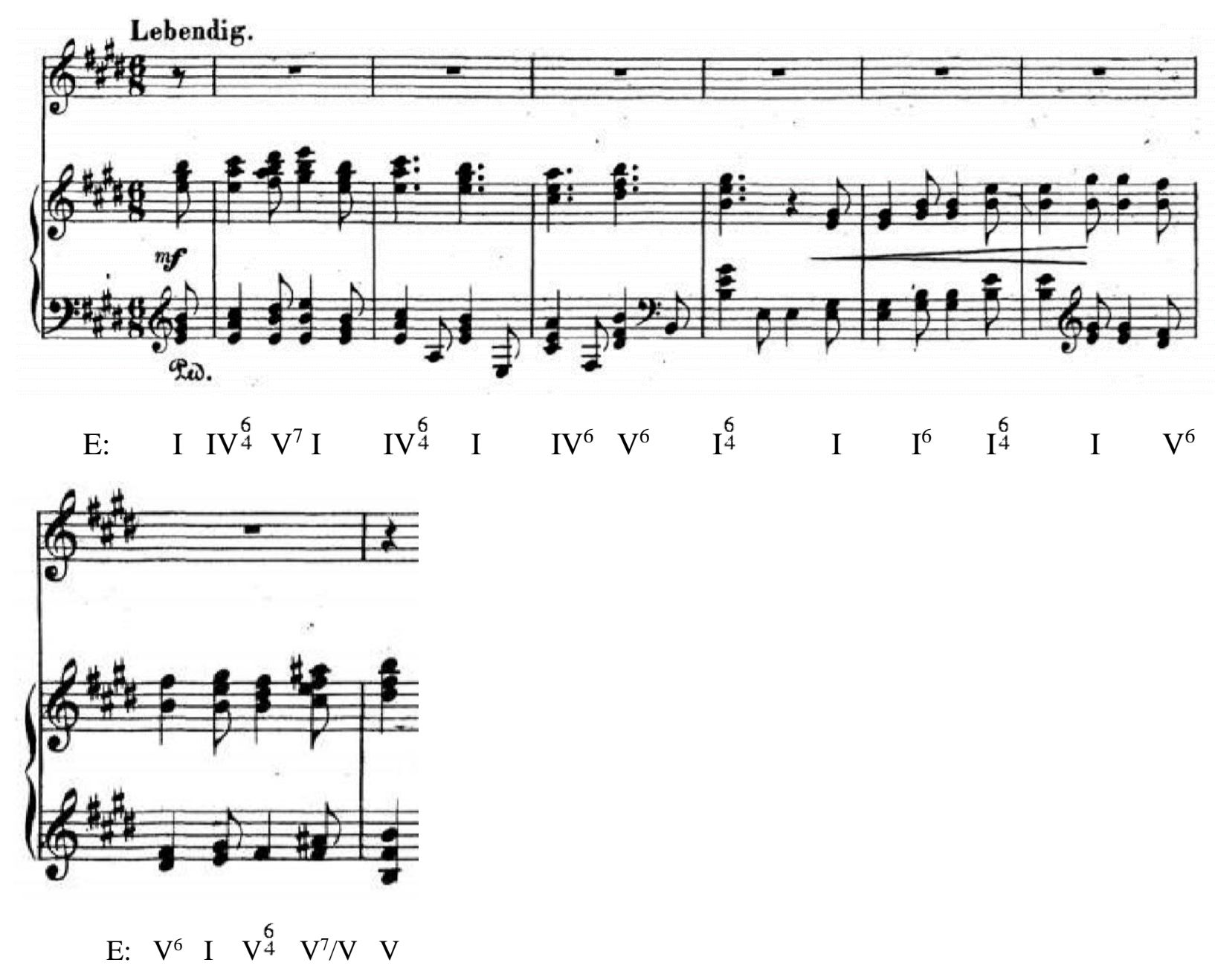

Figure 5-56. Schumann: “Aus alten Märchen winkt es” mm. 1-8

When the voice enters, the accompaniment is identical to the introduction, and the vocal line initially doubles the piano (see Figure 5-57): 


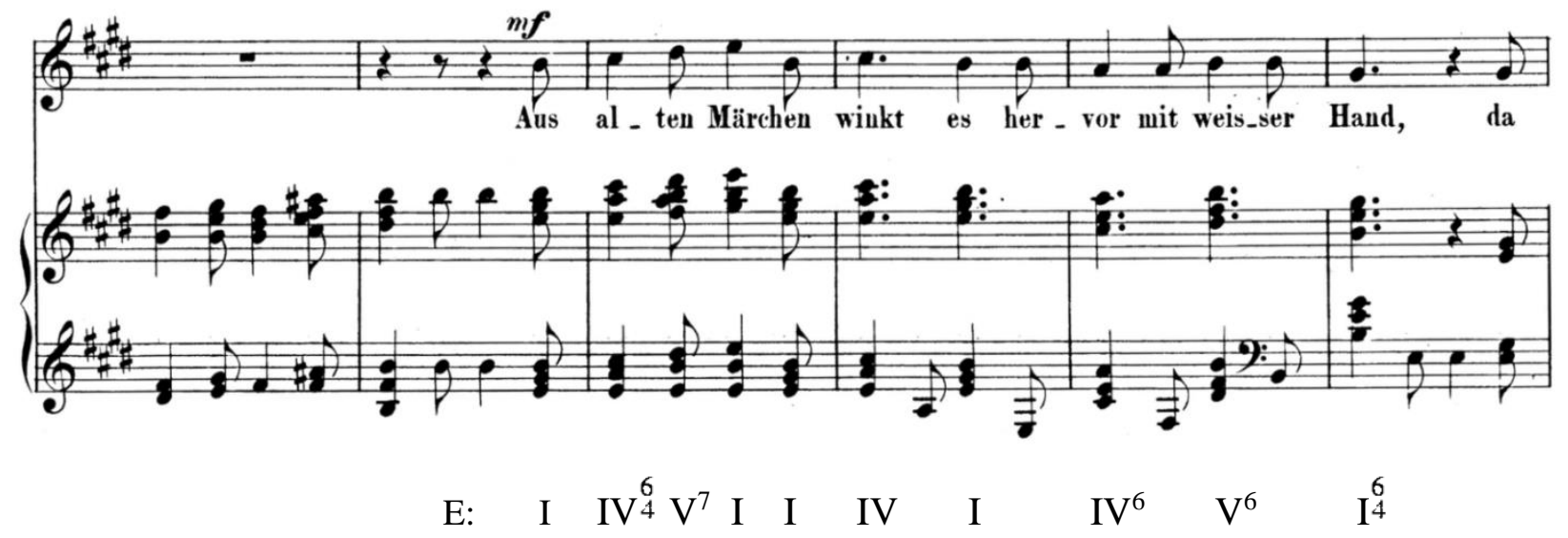

Figure 5-57. Schumann: “Aus alten Märchen winkt es” mm. 7-12

Schumann switches from the chordal writing to a thin texture and staccato figures in the second stanza which represents another feature of joyfulness. With the words "Blumen blühen" ("flowers bloom") and "Abendlicht" (“evening light") the two chromatic harmonies imply that the blooming flowers and the evening light give a playful mood for the poet (see Figure5-58): 

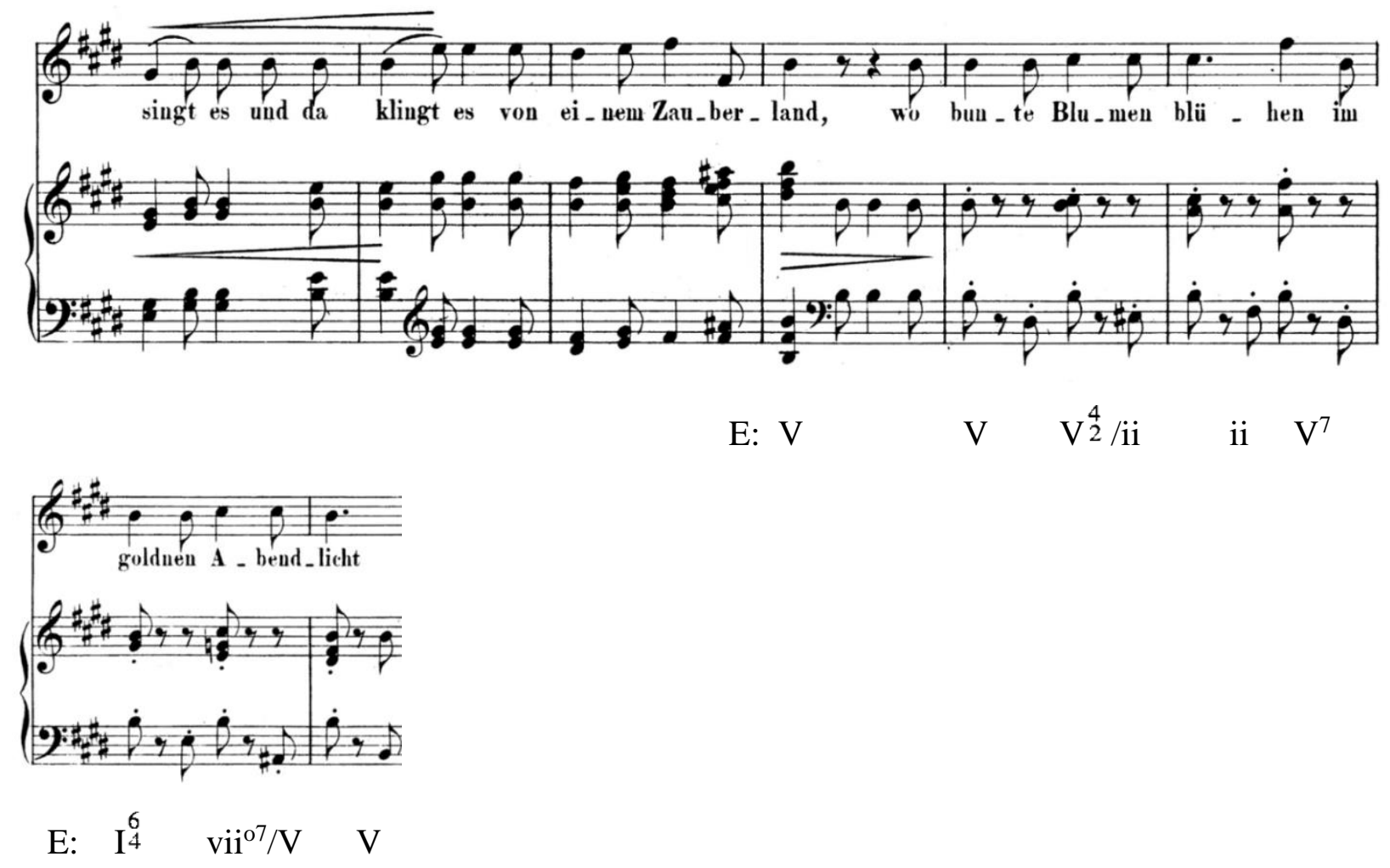

Figure 5-58. Schumann: "Aus alten Märchen winkt es" mm. 13-20

Schumann uses the opening motive in the piano for the interlude in measures 25 to 28 , but he transposes it to the key of $\mathrm{G}$ major. Instead of duplicating the vocal melody from the beginning, the voice enters with a new melody. Schumann utilizes a sequence between bars 29 and 36 in this new melody by modulating to $\mathrm{B}$, heightening the harmony to achieve an intensity of feeling, and doubles the melody with the piano (see Figure 5-59): 


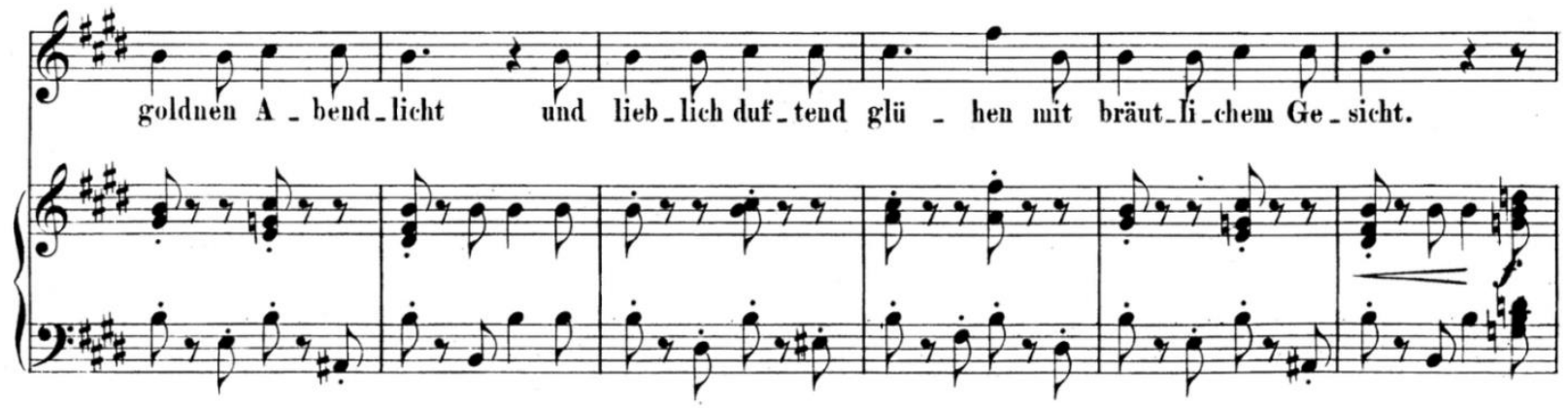

e: III

G: I
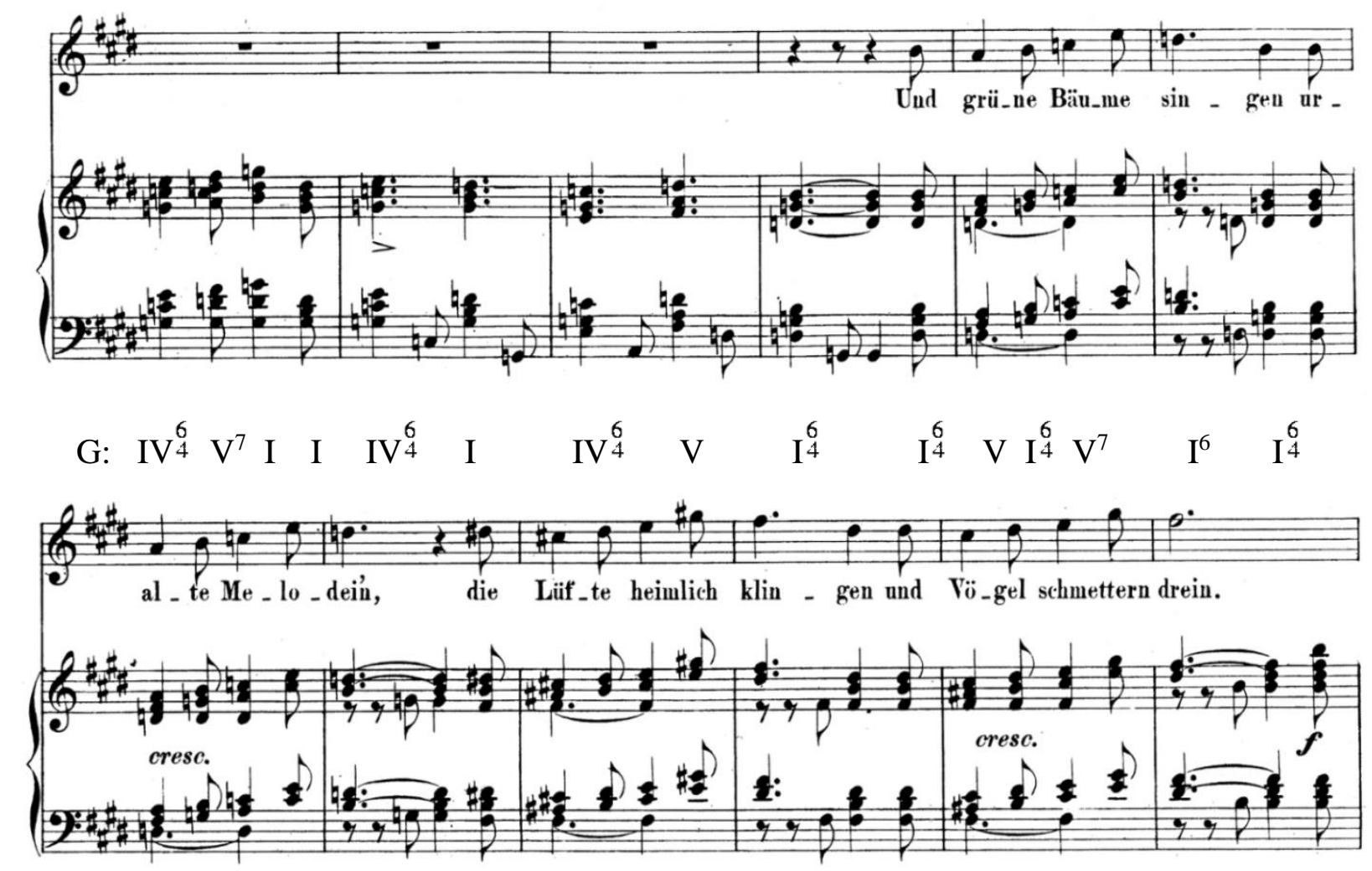
G: $\begin{array}{llllll}\mathrm{V} & \mathrm{I}^{4} & \mathrm{~V}^{7} & \mathrm{I}^{6} & \mathrm{I} & \mathrm{V}^{6} / \mathrm{iii}\end{array}$
$\begin{array}{llllllllllll}\text { B: } & \mathrm{I}^{6} & \mathrm{~V}^{4} & \mathrm{I}^{4} & \mathrm{~V}^{7} & \mathrm{I}^{6} & \mathrm{I}^{4} & \mathrm{~V} & \mathrm{I}^{6} & \mathrm{~V}^{7} & \mathrm{I}^{6} & \mathrm{I} \\ & & & & & & & & & & & \end{array}$

Figure 5-59. Schumann: “Aus alten Märchen winkt es” mm. 19-36

In measure 45, Schumann modulates from E major to B major, and the thicker texture continues as in the beginning. The melodic line in the voice leaps down an octave then goes up 
representing the poem's words "Und Nebelbilder steigen wohl aus der Erd' hervor" ("And misty images rise up from the earth") (see Figure 5-60):

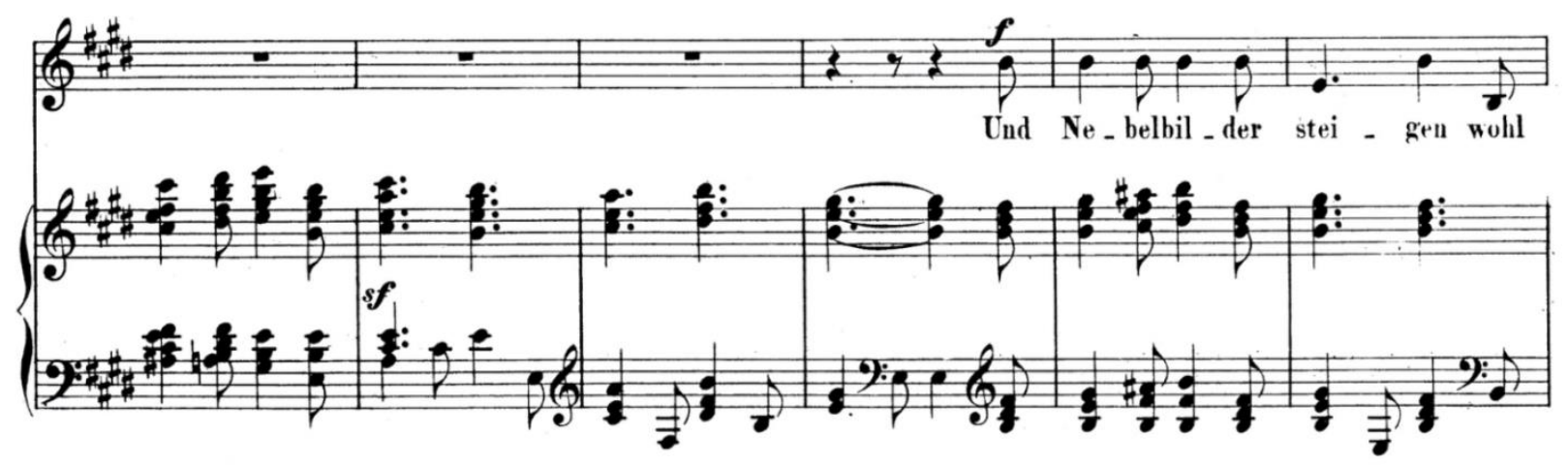

$\mathrm{E}: \mathrm{V} \quad \mathrm{I}^{6} \mathrm{~V} / \mathrm{V}$

B: $\mathrm{V}^{7} \mathrm{I} \quad \mathrm{IV}^{6} \quad \mathrm{I}$

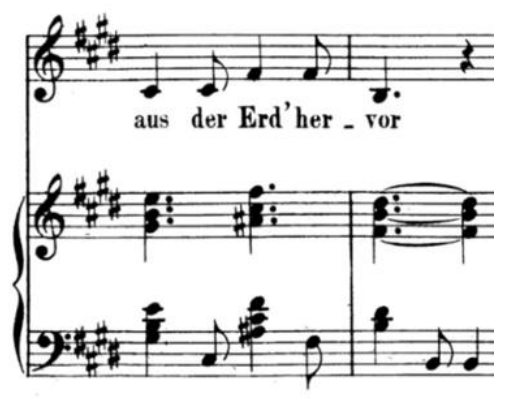

B: $\mathrm{IV}^{6} \quad \mathrm{~V}^{6} \quad \mathrm{I}$

Figure 5-60. Schumann: “Aus alten Märchen winkt es” mm. 37-44

In measures 55 to 68 , Schumann uses a sequence to create a dramatic high point between bars 57 and 64. In this section, Schumann applies a wider range in the voice with an ascending motion for "und laute Quellen brechen aus wildem Marmorstein, und seltsam in den Bächen strahlt fort der Wiederschein" ("and noisy springs break out of wild marble rock, and strange reflections gleam in the brooks.") Schumann uses a thick texture in the accompaniment and a sustained use of the damper pedal to manifest the "noisy" scene. He uses "Ach" ("Ah") twice as expressions of sighing as he returns to the home key of E major. (see Figure 5-61): 

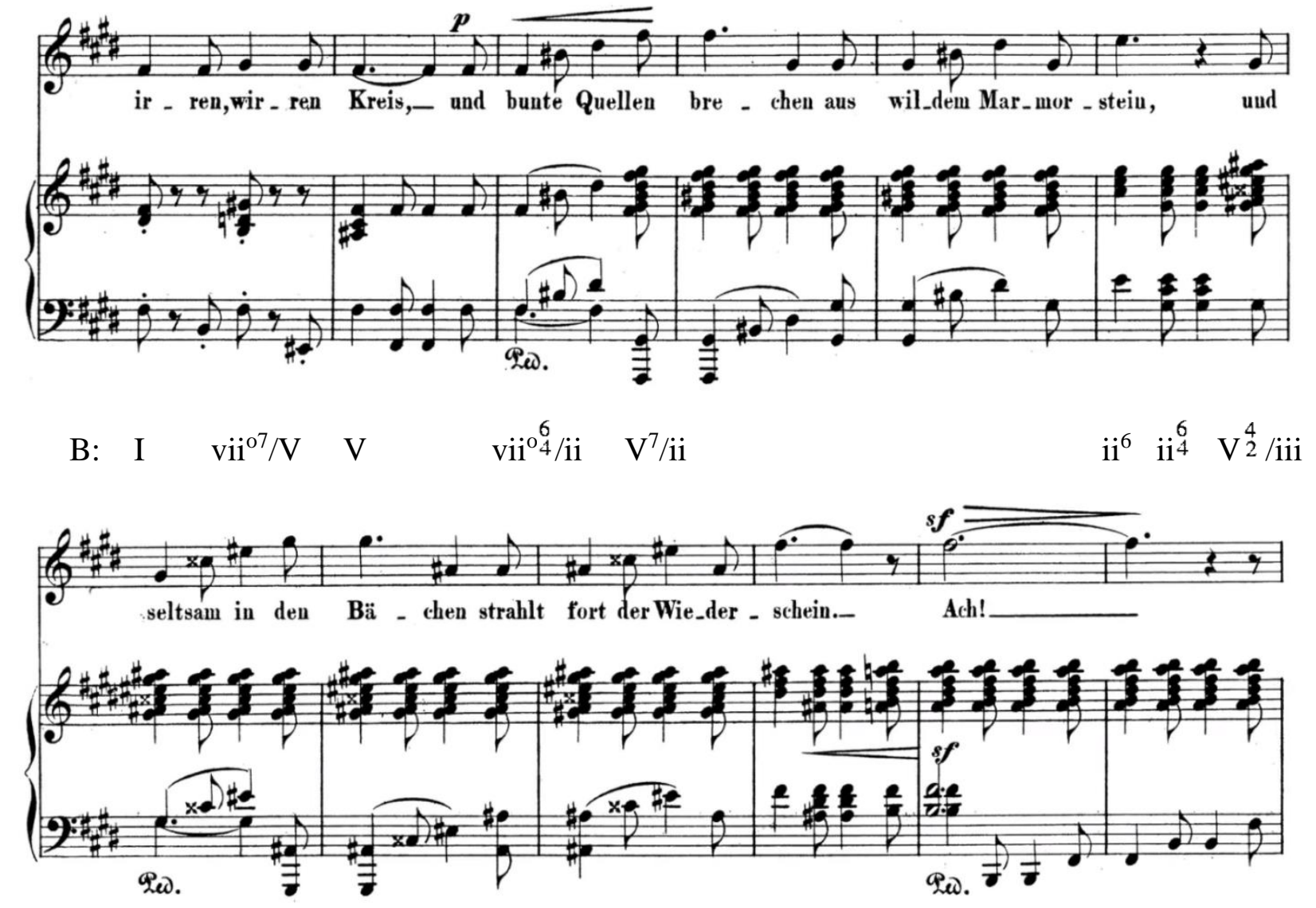
B:
$\mathrm{V}^{7} / \mathrm{iii}$
iii $^{6}$ iii $^{6} \quad \mathrm{~V}^{7} / \mathrm{IV}$

$\mathrm{E}: \mathrm{V}^{7}$

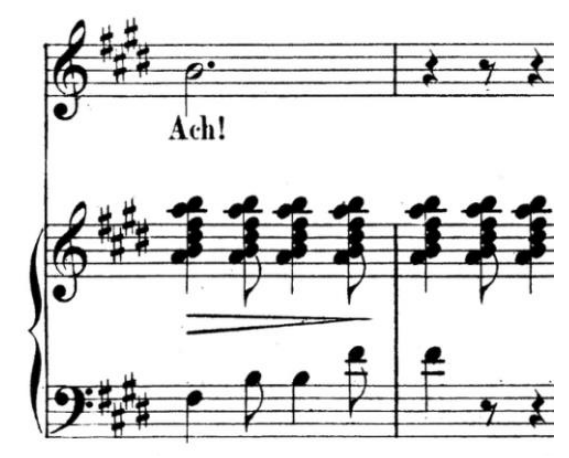

E: $\quad V^{5}$

Figure 5-61. Schumann: “Aus alten Märchen winkt es” mm. 55-68

With the diminuendo of "Ach!" Schumann abruptly transfers from Lebendig ("Lively") to Mit innigster Empfindung ("With the most intimate feeling"). The seventh stanza consists of 
two identical phrases, each phrase containing seven measures. Schumann's use of the slower tempo to represent the yearnings of the poet in the magical land, because that place is "frei" (“free,”) “selig” (“blissful,”) and his "Qual” (“torments,”) were relieved (see Figure 5-62):
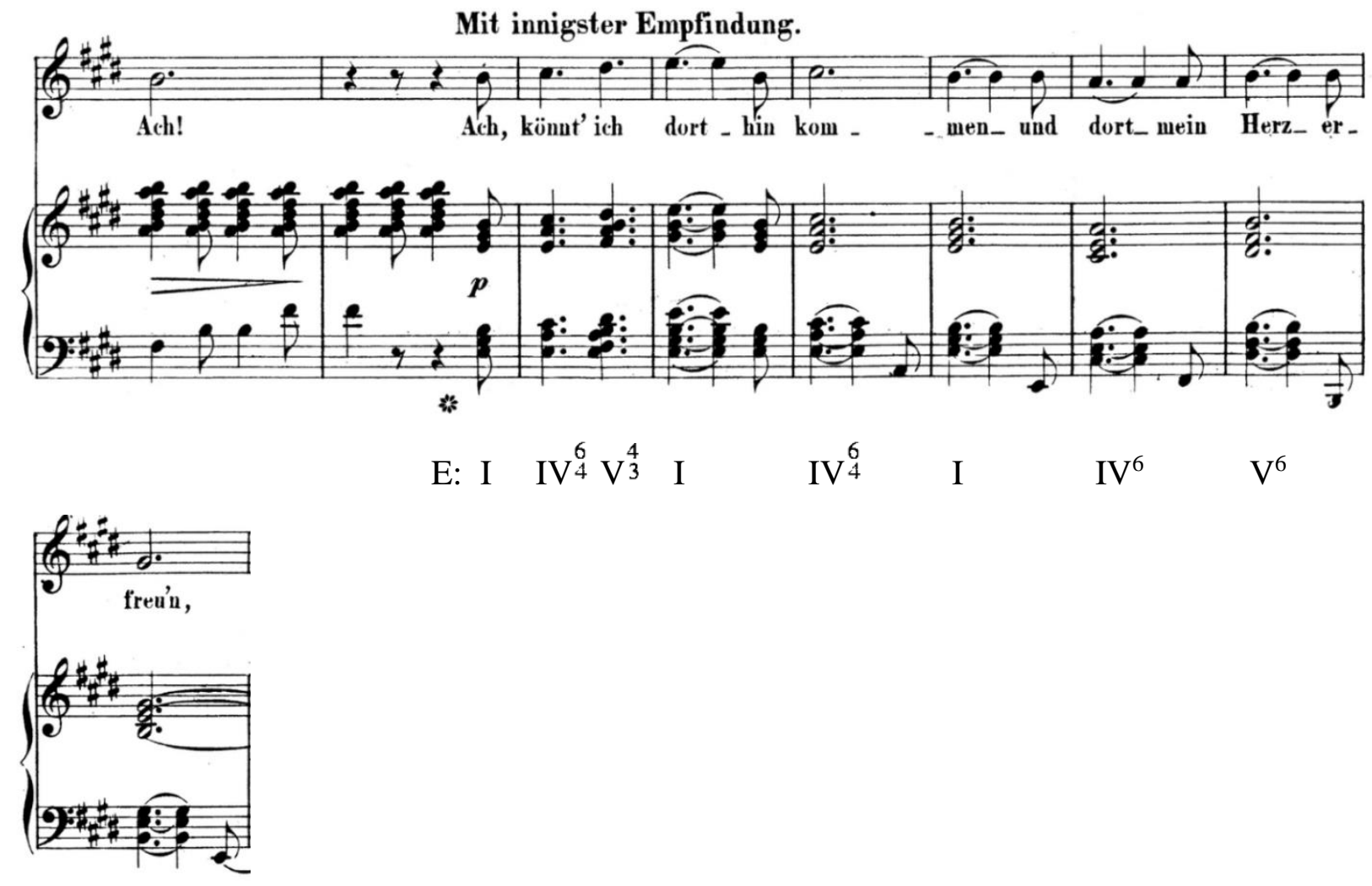

E: $I^{6}$

Figure 5-62. Schumann: "Aus alten Märchen winkt es” mm. 67-75

In the last stanza, Schumann uses parallel writing in both hands of the piano part and the voice to strongly represent the poet's longing for the dreamland (see Figure 5-63): 


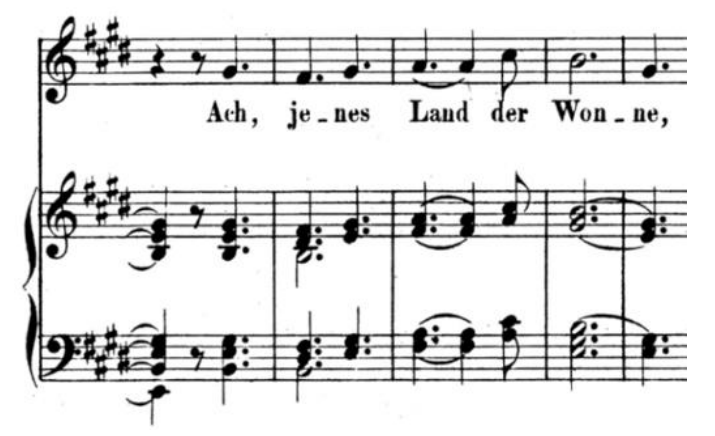

E: $\quad I^{I^{4}} \quad \mathrm{~V}^{\frac{6}{4}}$ ii $\quad$ I

Figure 5-63. Schumann: “Aus alten Märchen winkt es” mm. 84-88

In measure 96, a secondary leading-tone chord with a piano dynamic interrupts the dream as the morning sun appears. In measure 99, Schumann uses a common-tone diminished seventh chord to emphasize the word "Schaum" ("foam"), as the image of the beautiful land disappears like foam. Schumann sympathetically repeats the last words with a slower tempo of Adagio (see Figure 5-64): 


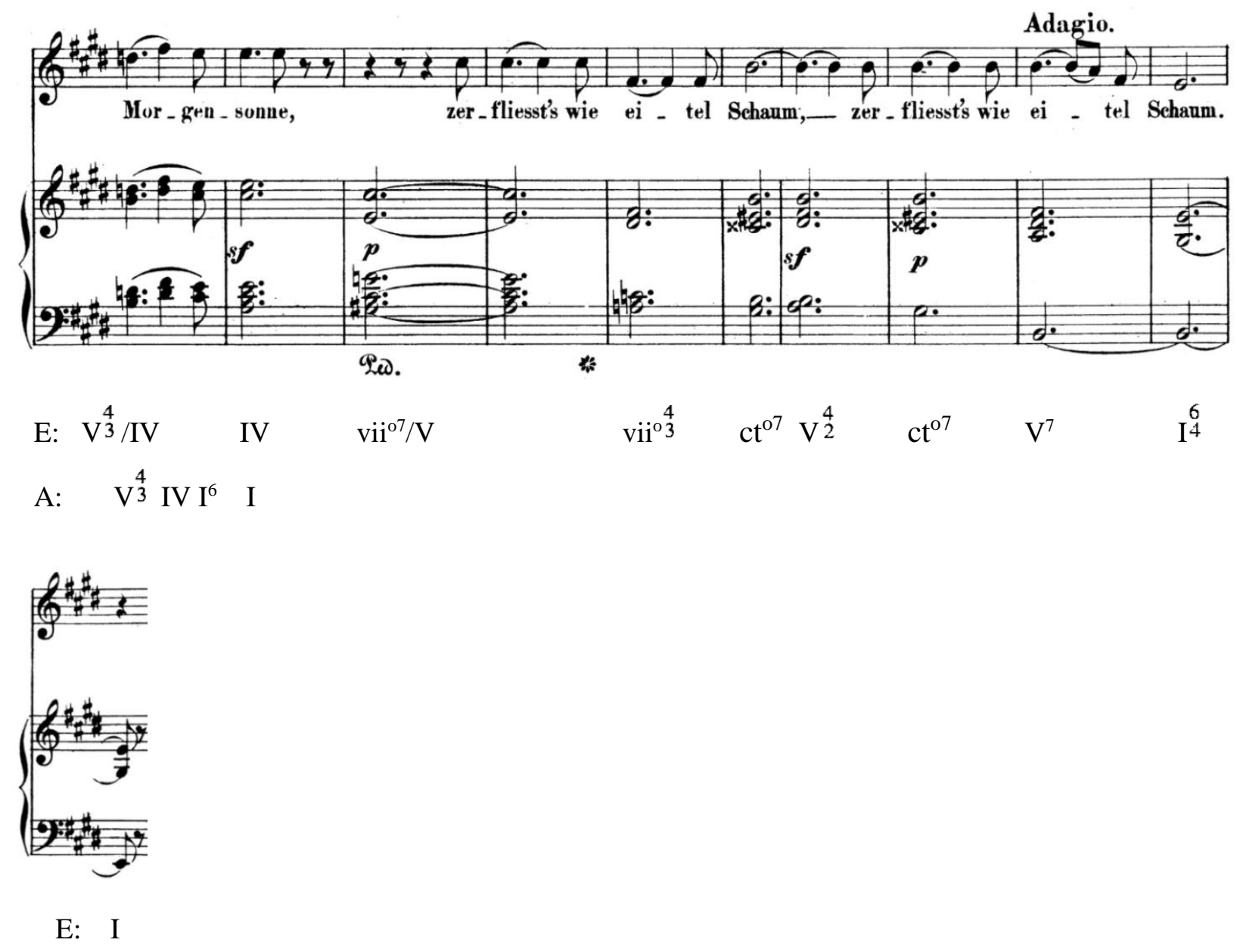

Figure 5-64. Schumann: "Aus alten Märchen winkt es” mm. 94-104

After a fermata prolongs the silence, Schumann brings back the familiar main theme as a distant memory of the magical land. Schumann interestingly uses a pedal marking to imply a sustained use of the damper pedal until the end of the postlude, which gives a blurred, distant memory effect within the quiet dynamic. He also interestingly keeps the eighth-note placement in the left hand of the final seven bars, a rhythmic effect that gives an unsettled feeling to the postlude (see Figure 5-65): 


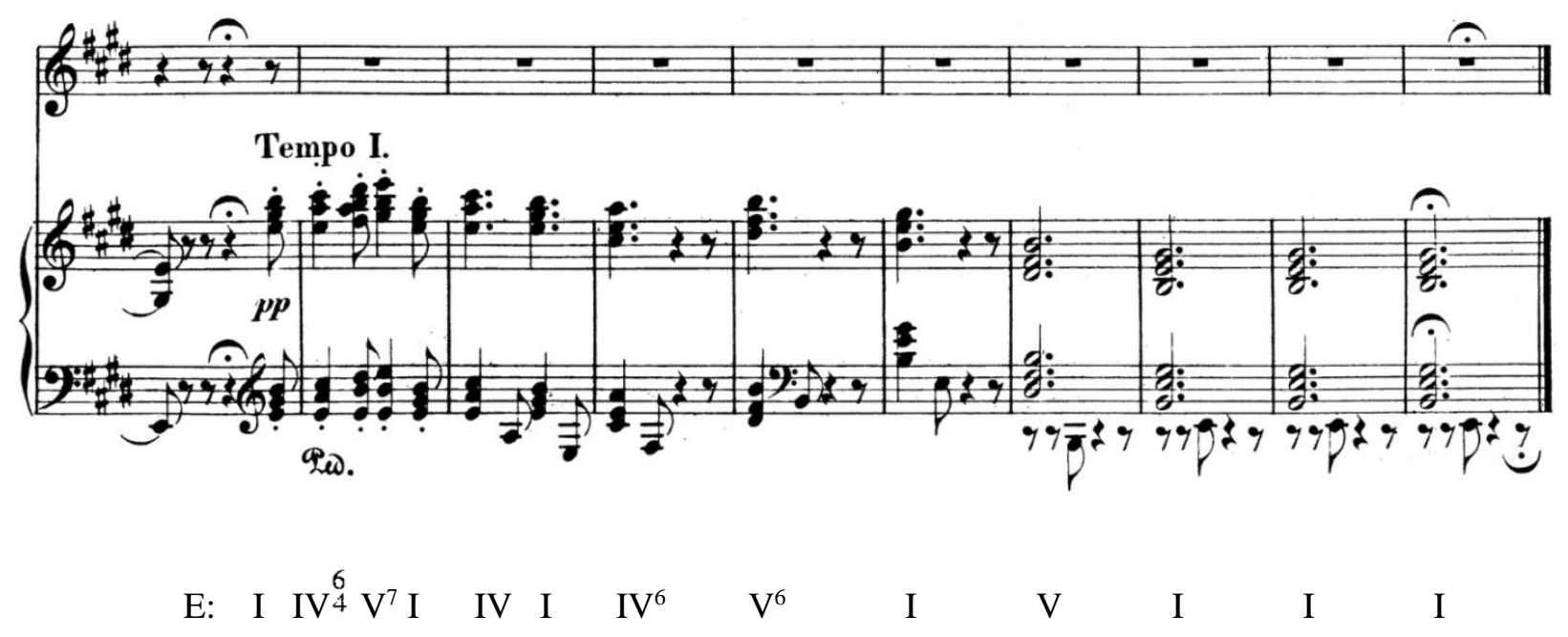

Figure 5-65. Schumann: “Aus alten Märchen winkt es” mm. 104-113

As the longest song of Dichterliebe, Schumann brings a dramatic mood change within both the cycle and the song from the exuberant first six stanzas to the melancholic last two. The postlude of "Aus alten Märchen winkt es" perhaps unites both emotions. There is liveliness in the music, and Schumann in a sense conceives it so instrumentally that even Charles Rosen considered it to be a scherzo ${ }^{83}$ As one of the most difficult songs in the cycle, the piano part is challenging to play, not only because of the chord figurations, but also the wide leaps in the left hand.

\footnotetext{
${ }^{83}$ Rosen, Charles, "Mountains and Song Cycles," in The Romantic Generation. (Cambridge, Massachusetts: First Harvard University Press, 1998), 211.
} 


\section{Die alten, bösen Lieder,}

Die alten, bösen Lieder, die Träume bös bos' und arg, die last uns jetzt begraben, holt einen grossen Sarg.

Hinein leg' ich gar Manches, doch sag' ich noch nicht was. der Sarg muss sein noch grosser, wie's Heidelbeger Fass.

Und holt eine Todtenbahre und Breter fest und dick auch muss sie sein noch länger, als wie zu Mainz die Brück'.

Und holt mir auch zwölf Riesen, eie müssen noch stärker sein, als wie der starke Christoph om Dom zu Köln am Rhein.

Die sollen den Sarg forttragen, und senken in's Meer hinab; denn solchen grossen Sarge gebührt ein grosses Grab.

Wisst ihr warum der Sarg wohl so gross und schwer mag sein? Ich senkt' such meine Liebe und meinen Schmerz hinein!
The bad old songs, The bad, evil dreams, - Let's bury them now, Fetch a big coffin.

In it I shall put many things, But I am not yet saying what. The coffin must be still bigger than The Heidelberg Tun.

And fetch a bier And firm, thick boards It must be still longer than The bridge at Mainz.

And fetch me also twelve giants, They must be stronger than The mighty St. Christopher In the cathedral at Cologne on the Rhine.

They shall carry the coffin off, And sink it deep into the sea; For such a big coffin Needs a big grave.

Do you know why the coffin Will have to be so big and so heavy? I want to bury in it both my love And my pain! ${ }^{84}$

Key: C-sharp minor

Form: Through-composed

Accompanying Style: Chordal, layered writing

Predominant Characteristics of Vocal Line: Dotted rhythms, wide range, triadic outlines

${ }^{84}$ Glass, Beaumont, Schumann's complete song texts. (Genesco, NY: Leyerle Publications, 2002). 73-4. 
"Die alten, bösen Lieder," is both the last song of Dichterliebe and the final poem of Heine's Lyrisches Intermezzo. The poet buries his love and pain in a large, heavy coffin. Heine uses analogy to compare the large coffin required to hold his enormous pain with the size of the Heidelberg Tun, a famous large wine vat, and the bier required to carry the coffin with the size of the bridge at Mainz. In order to carry the coffin, the poet needs twelve giants, and they must be strong like the statue of St. Christopher in the Cologne Cathedral. Schumann was moved by the poet's depictions of this pain and wrote a bold and dramatic piano accompaniment for the majority of the song. In the long, expressive postlude, recalled from song 12 "Am leuchtenden Sommermorgen," Schumann changes moods a final time and represents the poet's genuine feeling of love to end the cycle.

Schumann begins the song Ziemlich langsam (somewhat slow) with a solemn character. Schumann's use of the octaves in the piano recall "Im Rhein, im heiligen Strome," and "Ich grolle nicht." However, the octaves in this last song reveal a strength and a feeling of finality. The fortissimo dynamic and accents take the pain a step further, and lead into the first verse of the song (see Figure 5-66):

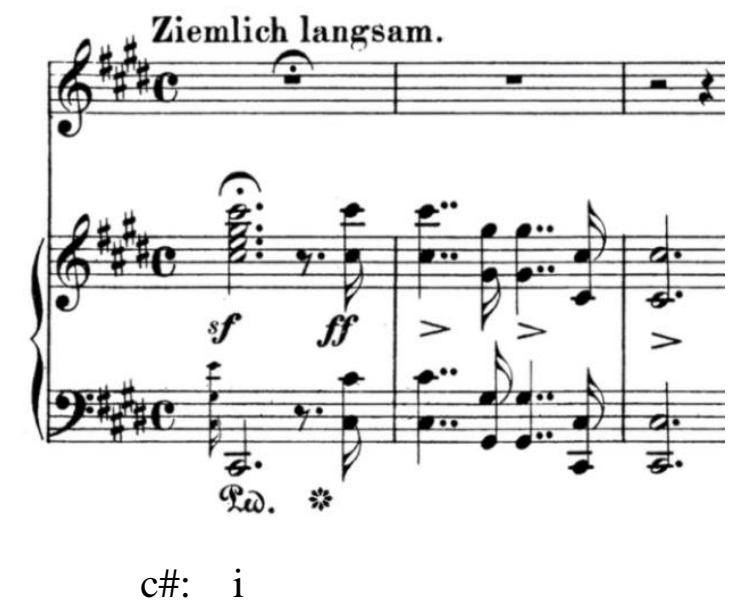

Figure 5-66. Schumann: "Die alten, bösen Lieder," mm. 1-3 
Schumann has the voice imitates the descending line of the opening introduction. From measures four to 11 , Schumann uses only i, iv, and $\mathrm{V}$ chords. The simple harmonies represent a determination of completely burying both the "old, wicked songs" and dreams that the poet had. Schumann uses a march-like rhythm throughout the first four stanzas, symbolizing the carrying of the coffin, which becomes a fundamental accompanying figure in this song (see Figure 5-67):
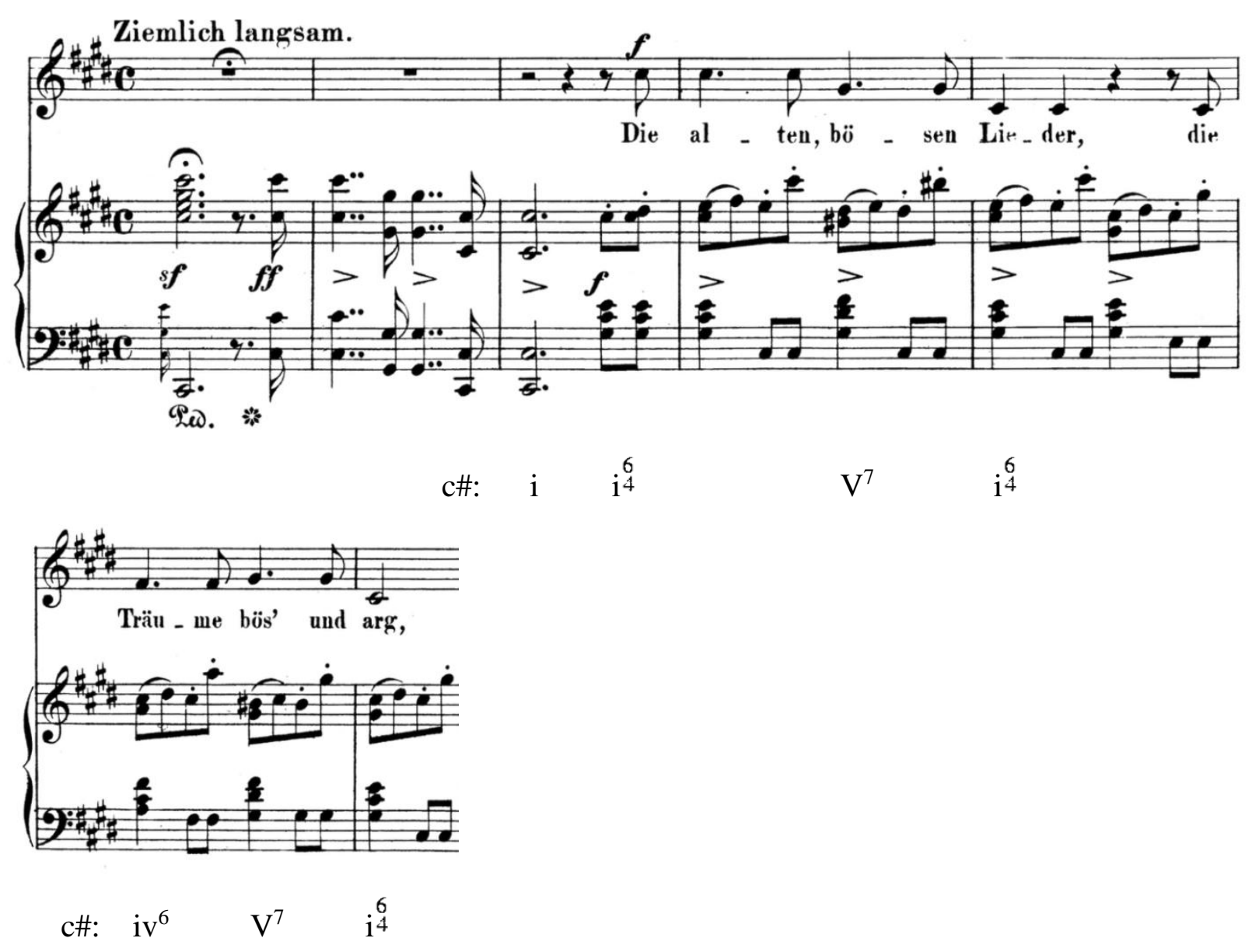

Figure 5-67. Schumann: "Die alten, bösen Lieder," mm. 1-7

Schumann uses a chromatic harmony to move to G-sharp minor for measures 12 to 15 .

The poet describes a large coffin where he can stow something away, but he does not reveal what it contains (see Figure 5-68): 


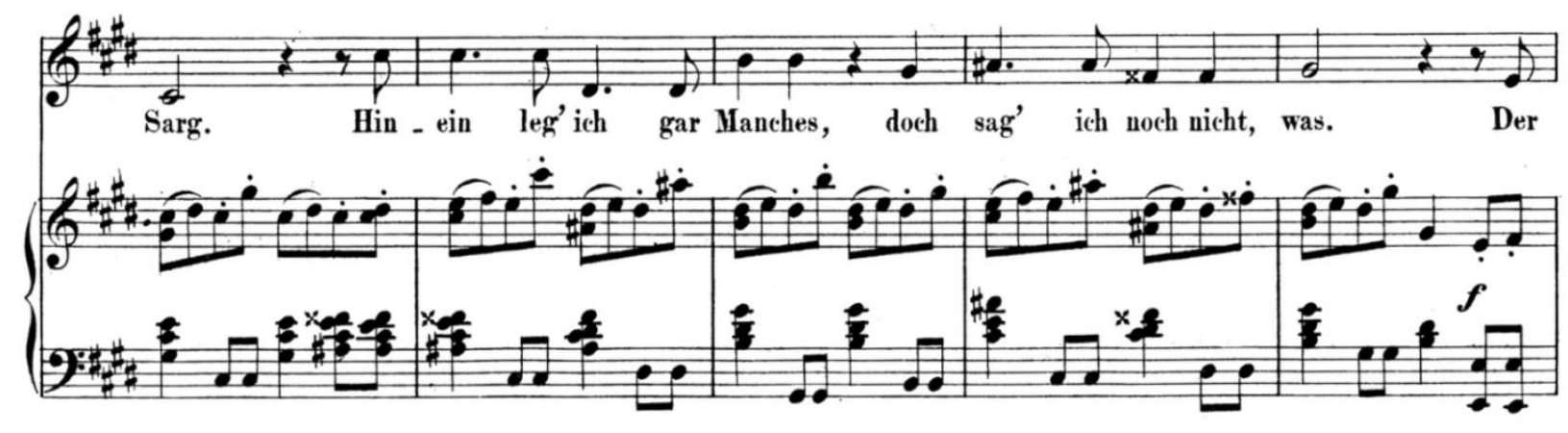
$\mathrm{c \#}: \quad \mathrm{i}^{6} \quad \mathrm{vii}^{\mathrm{0}}{ }^{6} / \mathrm{V}$
g\#: vii $^{6}{ }^{6}$
$V^{4} \quad i^{6}$
ii $^{\mathrm{o} 6}$
$\mathrm{V}^{4}$
E: $\quad$ iii $^{6}$
I

Figure 5-68. Schumann: “Die alten, bösen Lieder,” mm. 11-15

From measures 16 to 30, Heine respectively uses “grosser” (bigger), "länger” (longer), and "starker" (stronger) to gradually describe the heaviness of the coffin (see Figure 5-69): 


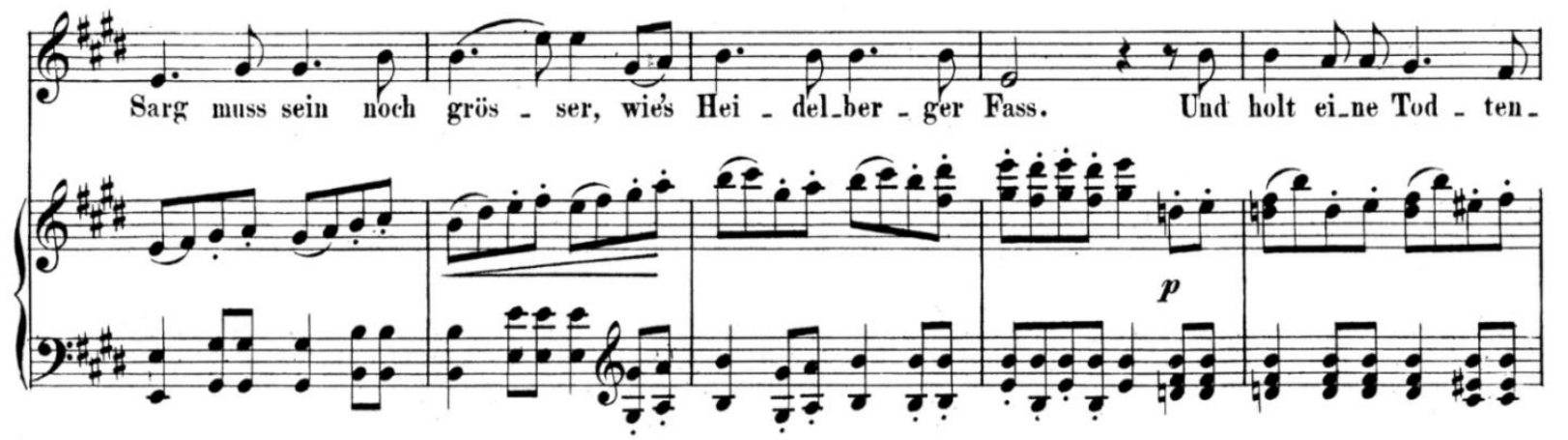
E: I
V I V I V I

$$
\text { f\#: VII iv }{ }^{6}
$$

$\mathrm{V}^{7}$

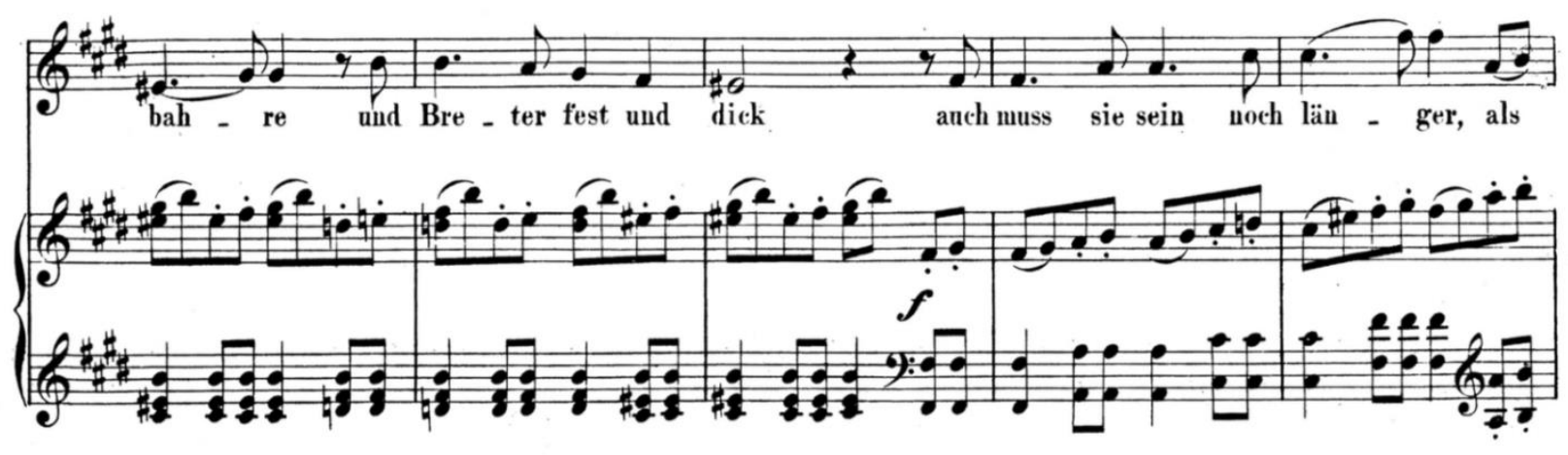
f\#: $V^{7}$
iv 6
$\mathrm{V}^{7}$
i
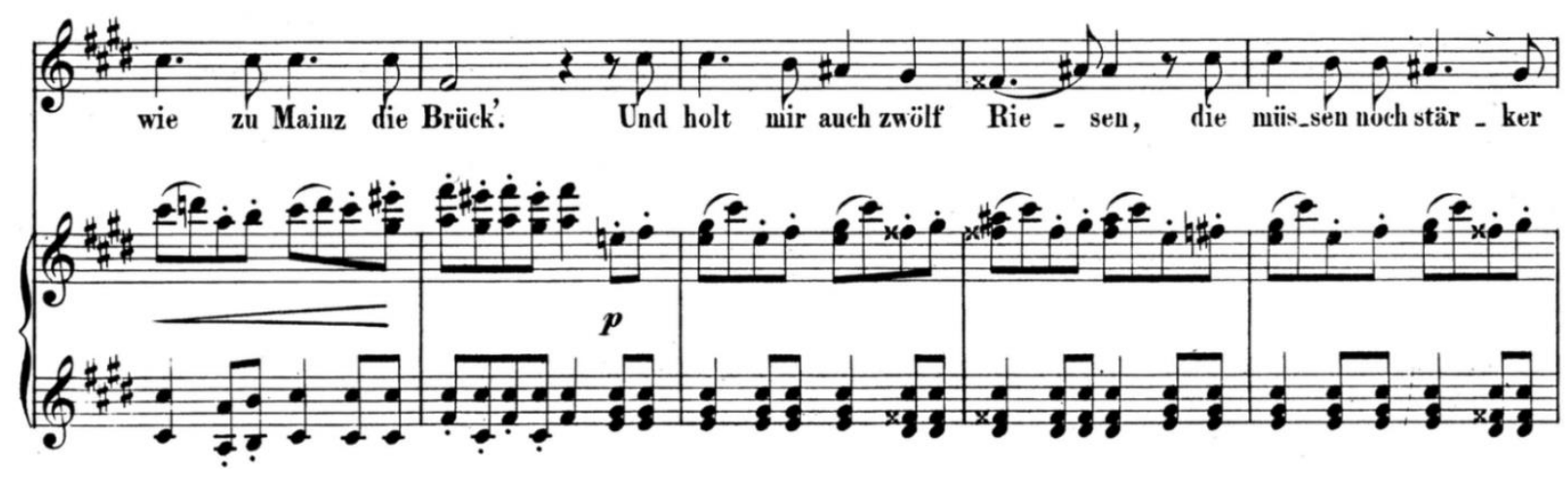

f\#: $\quad$ V i ViVi
g\#: VII iv ${ }^{6}$
$\mathrm{V}^{7}$
iv 6
$\mathrm{V}^{7}$

Figure 5-69. Schumann: “Die alten, bösen Lieder,” mm. 16-30 
Schumann fills out this crucial portion of the song with a long phrase, using three keys from measures 15 to 35 in the sequence of E, F-sharp, and G-sharp (see Figure 5-70):

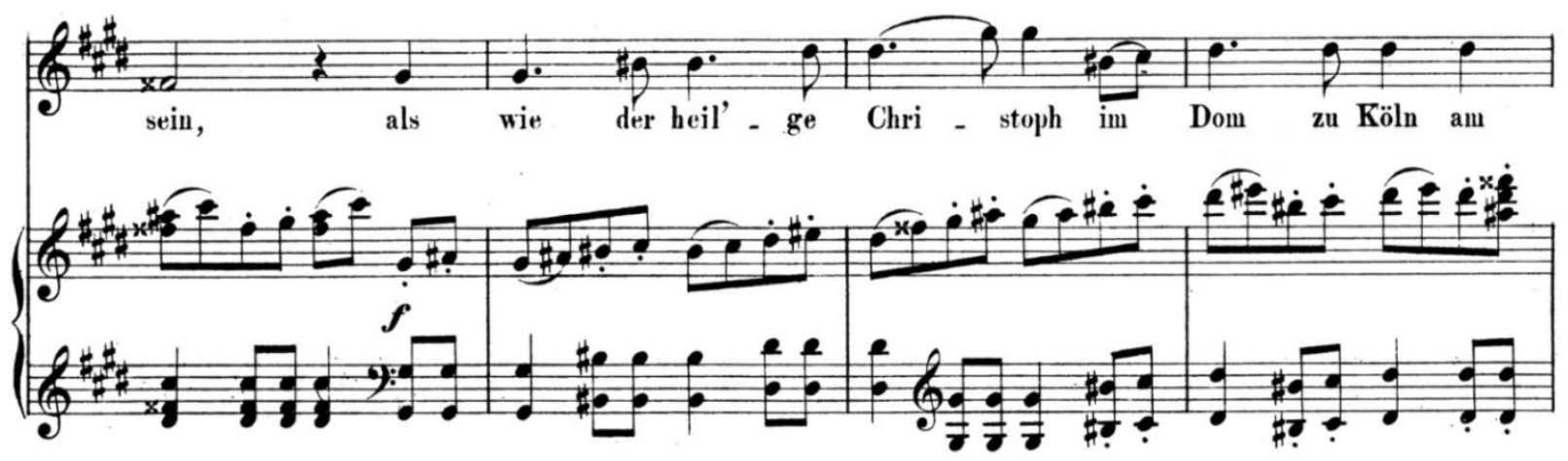

$\mathrm{g \# :} \quad \mathrm{V}^{7} \quad \mathrm{i}$

$\mathrm{V}$

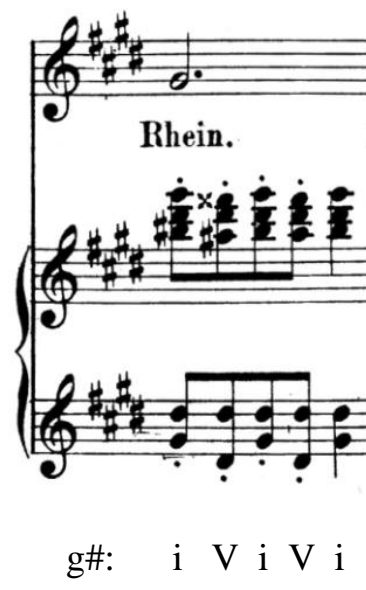

Figure 5-70. Schumann: “Die alten, bösen Lieder,” mm. 31-35

Schumann changes the accompaniment style in the penultimate stanza of the poem. The strong chords with the accent on the weak beats depict the twelve giants uneasily carrying the heavy coffin down to the sea until measure 39 . Schumann chooses to complete the phrase with a diminished chord for color. This cadence and Sforzando represent the poet's sorrowful mood, and the diminished chord heightens the drama. In measure 43, Schumann uses the lowest note of the vocal line, C-sharp, to depict the "Grab" ("grave") (see Figure 5-71): 


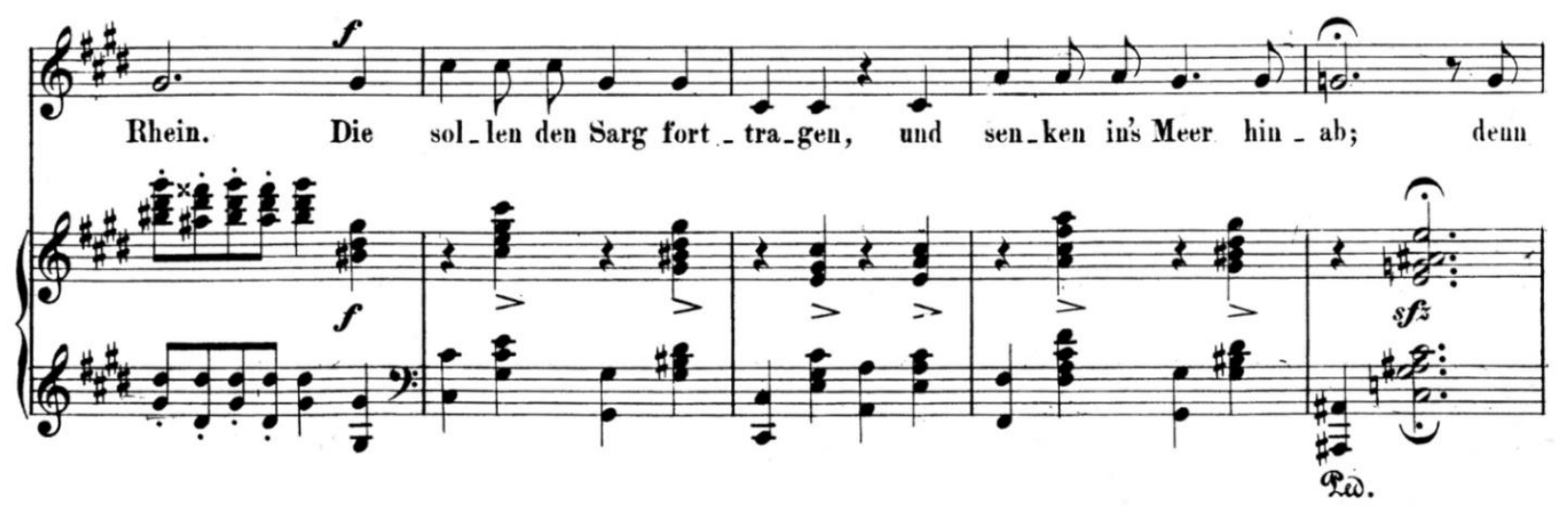

g\#: i

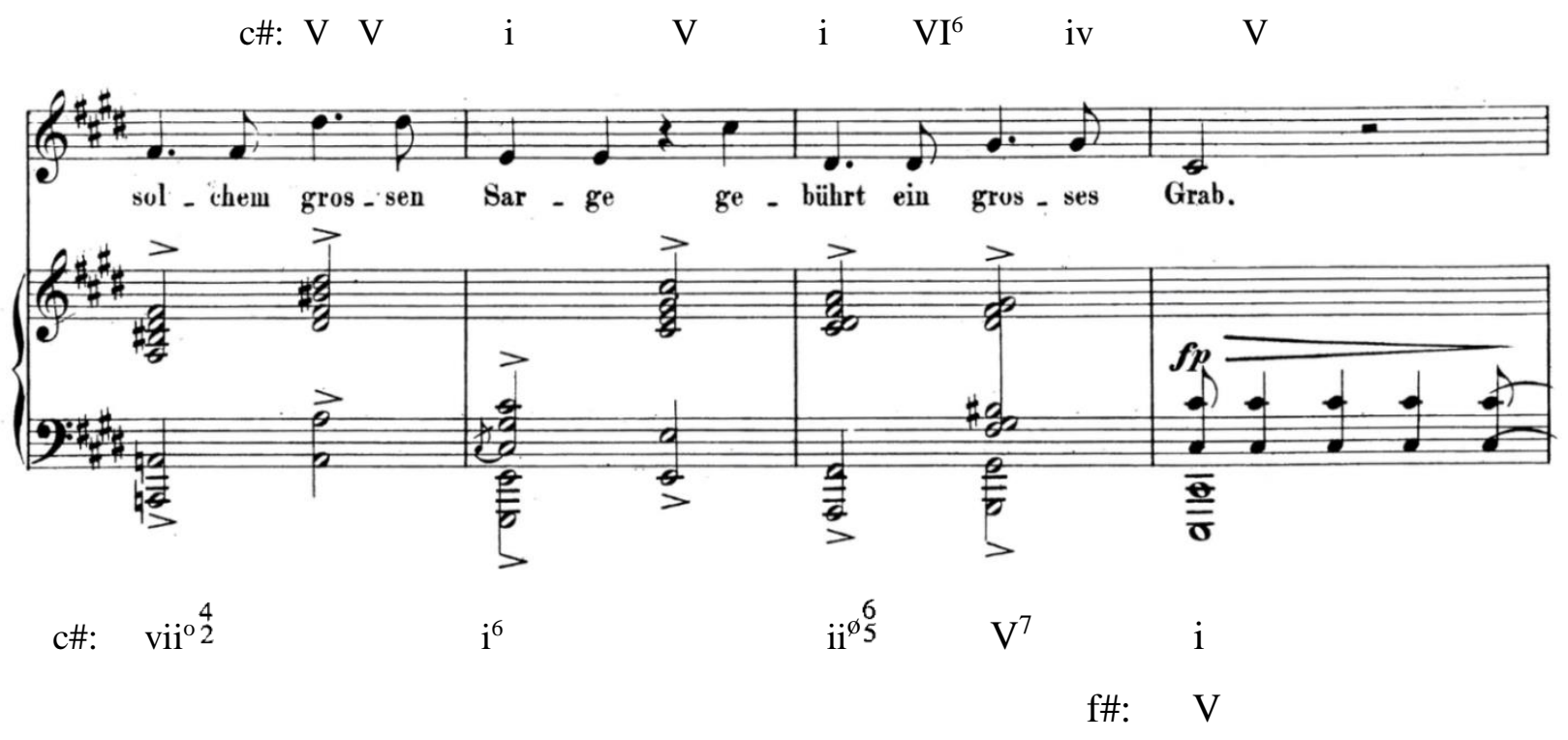

Figure 5-71. Schumann: “Die alten, bösen Lieder,” mm. 35-43

When the song reaches the last stanza, Schuman sets Heine's intriguing question-andanswer format to end the vocal part. In the first line, Schuman uses a soft dynamic, and the voice steadily stays in the middle range with repeated notes while the piano plays a restless syncopated rhythmic pattern. In the second line, Schumann moves the voice an octave higher to clearly answer the question in an Adagio tempo. Schumann intentionally uses register to distinguish the differences between love and pain. In measures 48 to 52, Schumann returns to the home key of C-sharp minor and once again leaves the piano to resolve the vocal line (see Figure 5-72): 

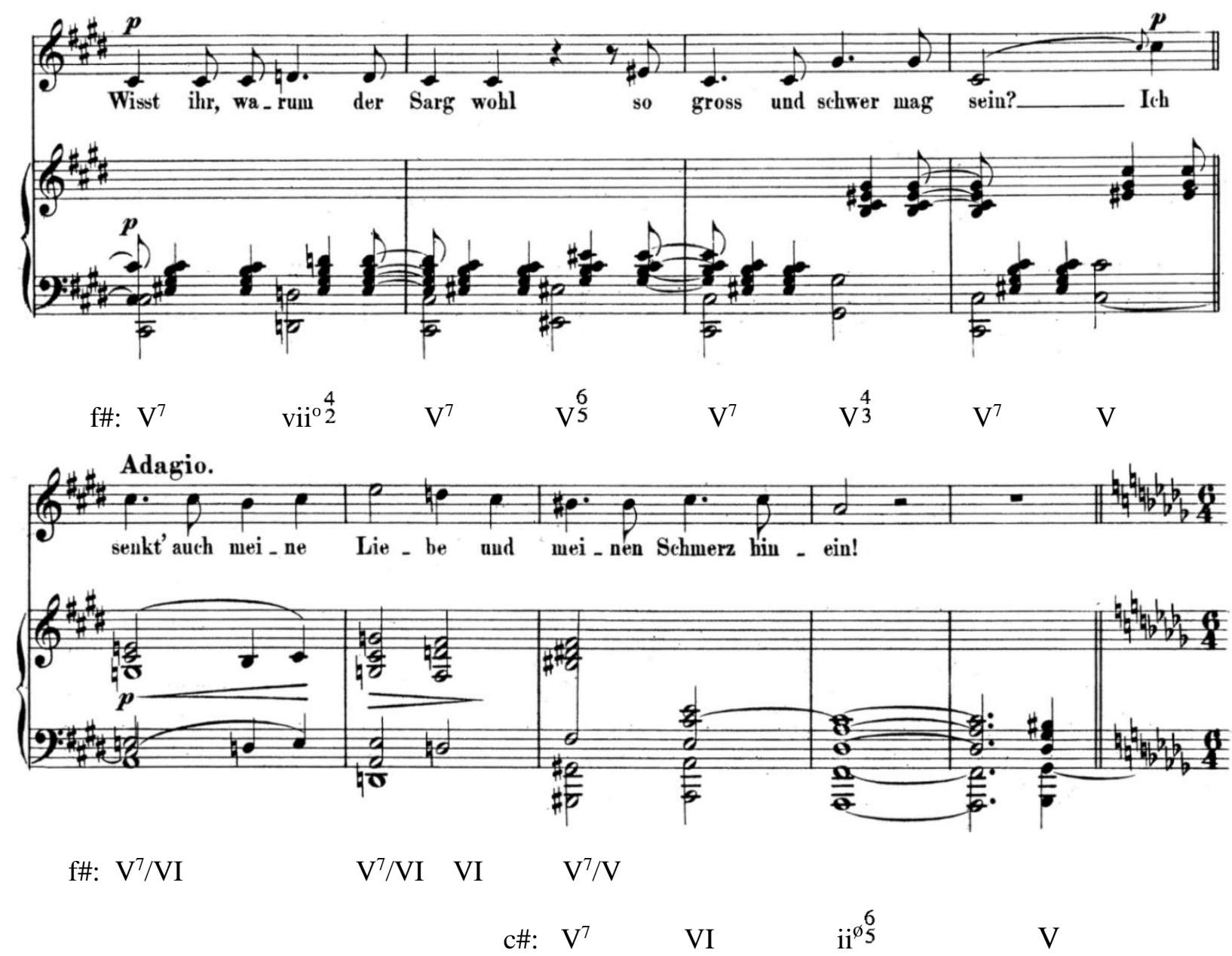

Figure 5-72. Schumann: "Die alten, bösen Lieder," mm. 44-52

Finally, Schumann uses a prolonged postlude to illustrate the poet's last statement of love. As the longest postlude of the cycle, the main theme originated in song 12 "Am leuchtenden Sommermorgen.” Schumann uses a parallel key change of C-sharp minor to D-flat major as well as a meter change, both of which are the first time Schumann employs such in the entire cycle. Schumann is not only raising an interval of a minor third from the original B-flat major of song 12 to D-flat major, but more importantly conveying the idea of forgiveness and reconciliation, which is profoundly the essence of Dichterliebe. In measure 54, Schumann 
stresses the last chord $\mathrm{vii}^{4}{ }^{4}$ /ii by using an uncommon symbol of crescendo and diminuendo on a single chord, indicating an accent or special color (see Figure 5-73):

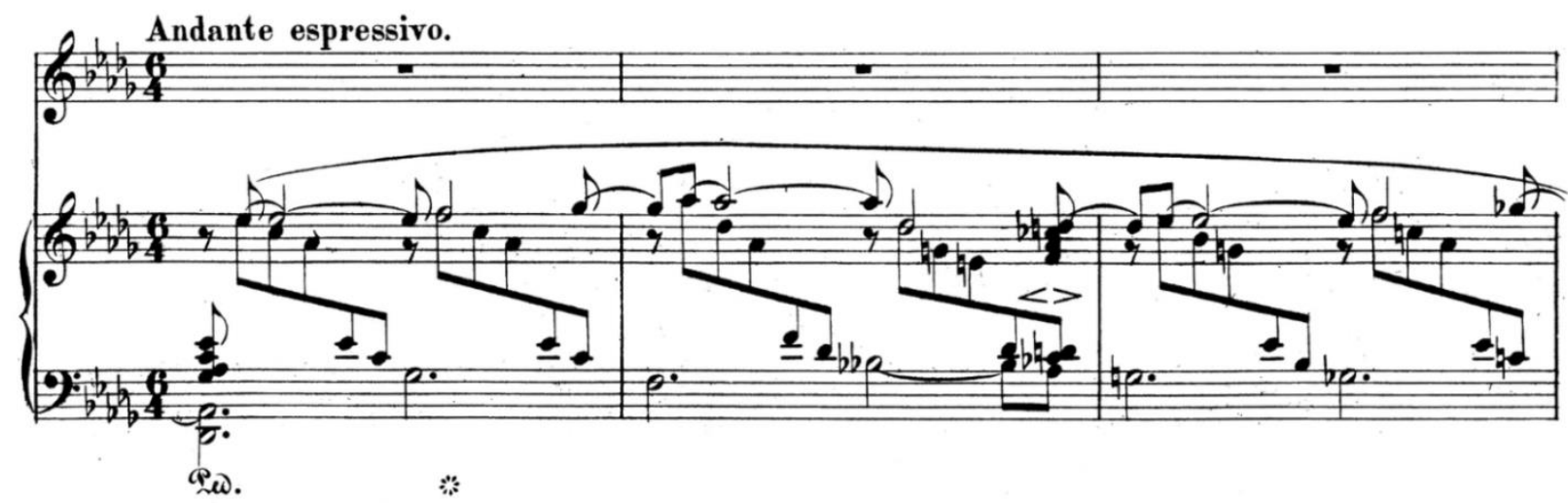
$\mathrm{Db}: \mathrm{V}^{7}$
$\mathrm{I}^{6}$
$\mathrm{Ger}^{+6} \quad \mathrm{vii}^{\mathrm{4}}{ }_{3}^{4} / \mathrm{ii} \mathrm{V} / \mathrm{V}$
$\mathrm{V}_{2}^{4}$

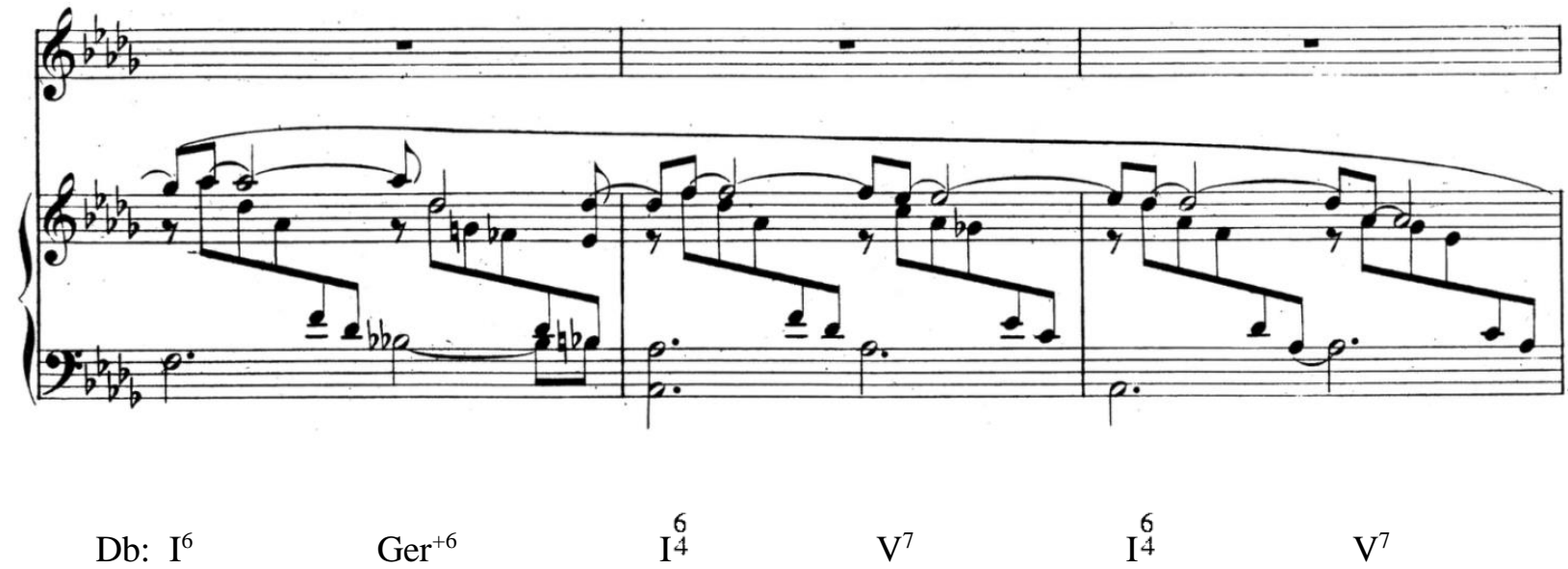

Figure 5-73. Schumann: "Die alten, bösen Lieder,” mm. 53-58

In the second part of the postlude, the music begins with a tonic chord with a major $7^{\text {th }}$ and a G-flat suspension. In measures 59 and 60, Schumann employs an improvisatory-like passage which he has never used before in the cycle, almost as if to reminisce. Next, Schumann writes a long phrase from measure 61 to the end, but the phrase consists of several fragments. Schumann takes measure 61 as the primary material to develop musically and emotionally for 
the next four bars and reaches the climax of G-flat in measure 64. Lastly, in order to symbolize the poet's love and pain fading away, Schumann ends the song with three repetitive phrases, varying the last one for the final cadence. One of the most beautiful parts of the song follows the last three Fs in the top voice, appoggiaturas, which heighten the tone color of the postlude. Schumann ends the song with three uses of dominant to tonic progressions, and uses the note Gb as a suspension for the last time in order to create a delayed resolution, as one final expression of longing or tribute to the unrequited love (see Figure 5-74): 


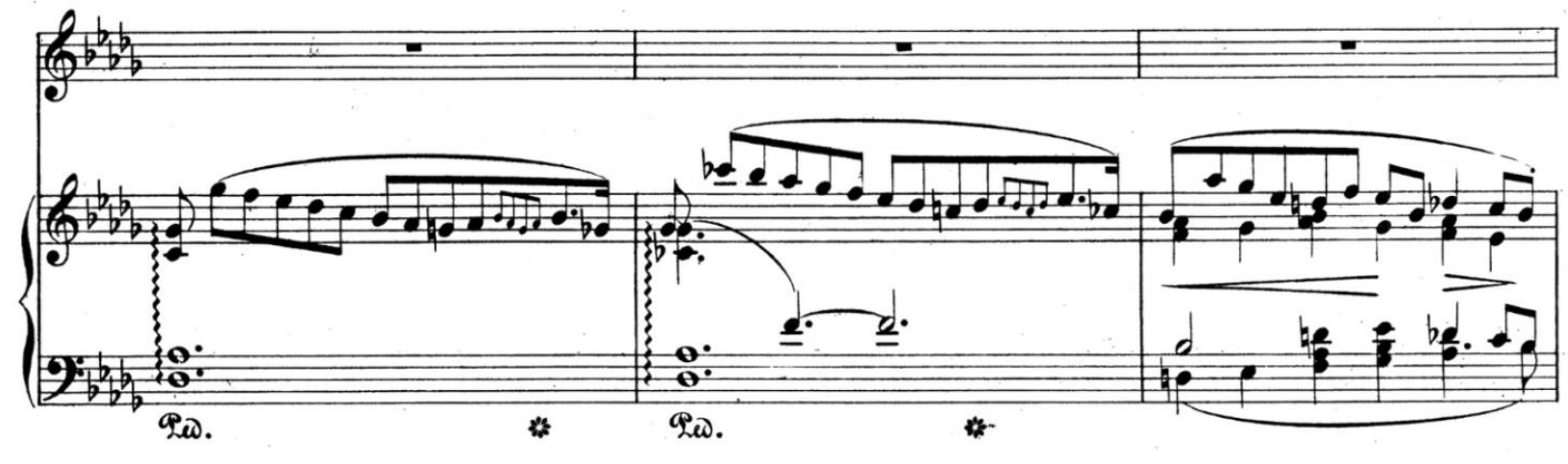
$\mathrm{Db}: \mathrm{I}^{\mathrm{M} 7}$
$\mathrm{V}^{7} / \mathrm{IV}$
$\mathrm{V}^{6} / \mathrm{ii}^{\mathrm{ii}} \mathrm{V}^{3} / \mathrm{ii}^{\mathrm{i}} \mathrm{ii}^{6} \mathrm{I}^{6} \mathrm{~V} \mathrm{~V}$

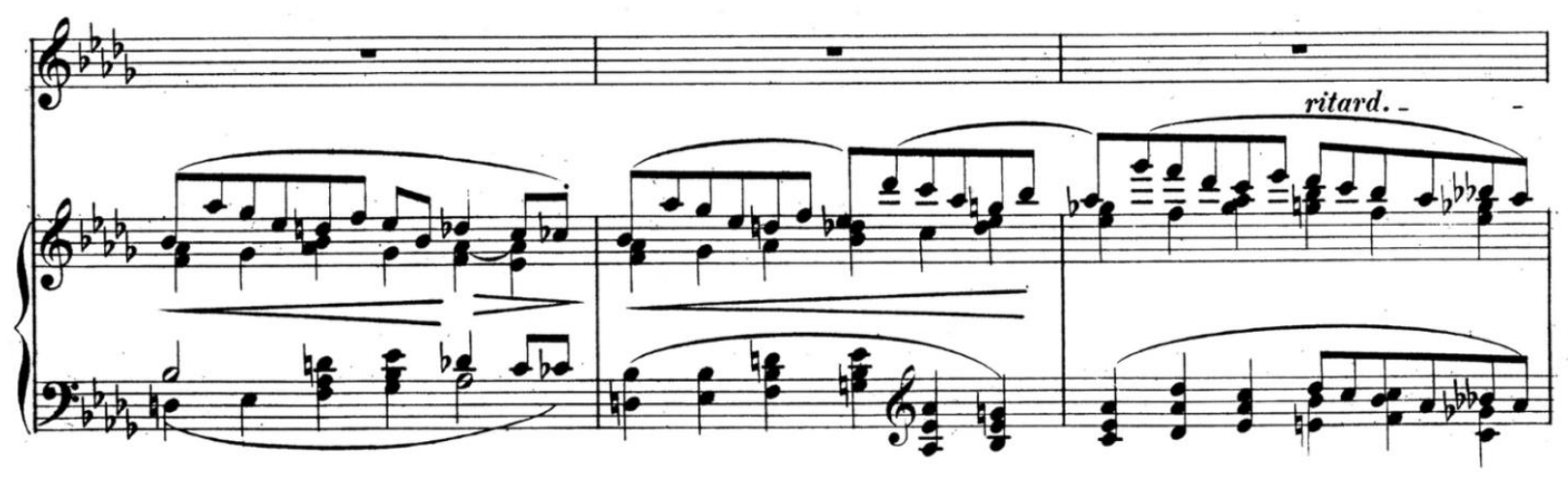

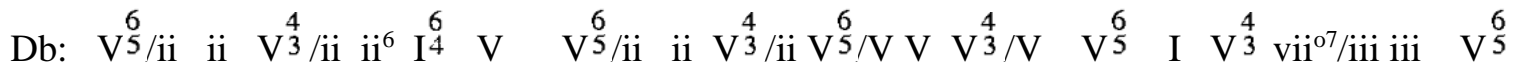

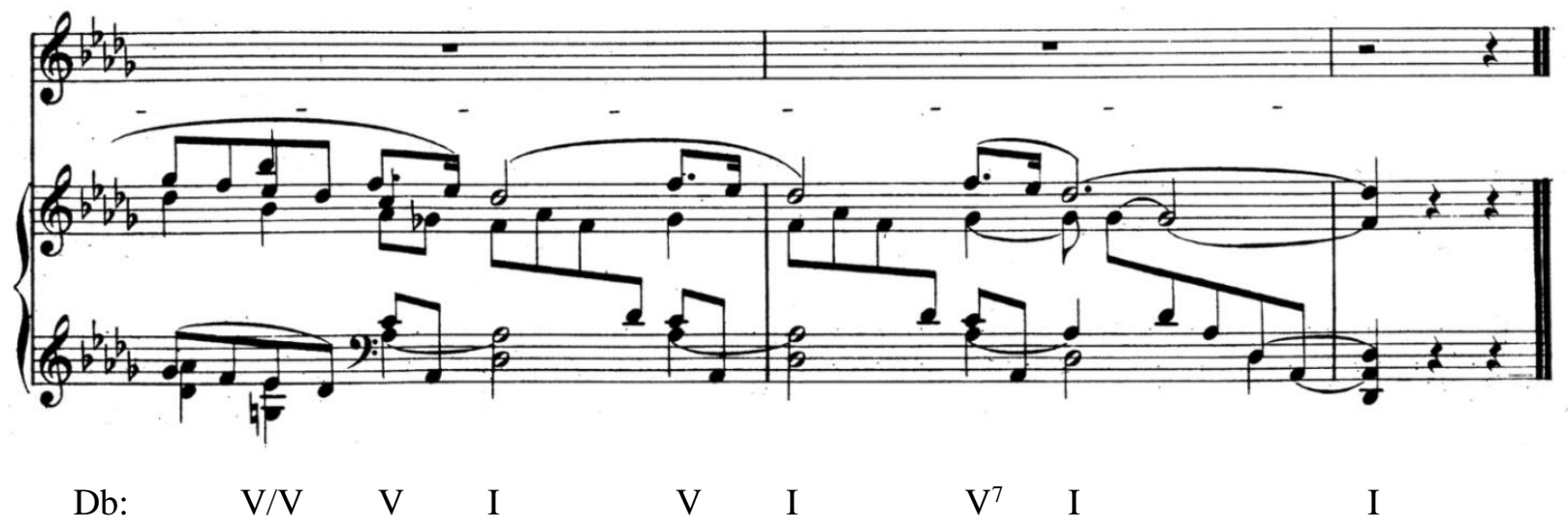

Figure 5-74. Schumann: "Die alten, bösen Lieder,” mm. 59-67 
The piano postlude of "Die alten, bösen Lieder," is a highlight of the entire cycle: "for

Schumann the pianist, it is fitting that the piano resolves and completes the cycle." ${ }^{, 85}$

${ }^{85}$ Kimball, Carol, "Part II Literature," in Song: A Guide to Art Song Style and Literature. (Milwaukee: Hal Leonard Corporation, 2006), 80. 


\section{CHAPTER VI}

\section{Conclusion}

Dichterliebe, Op. 48 is possibly the greatest song cycle of the nineteenth century, not only containing beautiful music, profound poetry, astonishing mood changes and depth of expression throughout, but also representing an important aspect of collaboration with the equality of the voice and piano parts. The singer and pianist must absorb extensive knowledge of each song's poetry and musical elements to establish a collaborative foundation: words, form, harmony, melody, rhythm, and texture.

Schumann uses modified strophic and through-composed as the main forms for the entire song cycle. The two different forms precisely represent Heine's texts, in which he either maintains a singular emotion or establishes a mood change in the poem. Schumann adopts the two kinds of structures because they conform to Heine's writing style and forms. In addition, the sixteen songs of varying length consist of seven songs with an introduction, eight songs with interludes, and 14 songs with a postlude. Eight songs have extended postludes, and seven songs have brief ones. In addition, Schumann's postludes are important to the structure: they not only continue the mood from the beginning of the song, but also accentuate the main idea of the song again and sometimes offer a reflection that only the piano alone could do.

For harmony, Schumann often uses chromatic chords, such as augmented sixth chords, Neapolitan, secondary dominants, and common-tone diminished sevenths to emphasize special settings of the words. He frequently uses enharmonic spellings of the German augmented sixth 
chord to move colorfully and sometimes surprisingly between tonalities. He uses modulation, tonicization, and mode mixture to highlight special moments as well. For example, the first song "Im wunderschönen Monat Mai” depicts falling in love, and it is the only song to feature an ambiguous tonality, which represents an unsettled mood of the poet for his beloved and sets the mood for the cycle. Secondly, song 12 "Am leuchtenden Sommermorgen" is the only song in the entire cycle to begin with a chromatic chord, where Heine introduces a new theme of forgiveness. Here, Schumann uses a dissonant chord, the German augmented sixth with an unexpected resolution, to signal the emotional turning point. Schumann tends to set up a unique harmony for each song in order to highlight the depth of the poetry's meaning.

For melody, Schumann text paints using a variety of techniques including remaining on a single pitch for a more desolate emotion, using triadic outlines for simpler folk-song like melodies, and incorporating clear traditional phrase structures. The piano and voice share melodic material equally, with the voice often imitating the piano's melodic line found in the introduction but slightly modified. Schumann also uses the piano to resolve the melodic line of the voice, a compositional technique that represents how a complete melodic phrase needs to be performed collaboratively by the singer and pianist.

For rhythm, Schumann typically utilizes a consistent rhythmic pattern throughout an entire song or a large portion of it, which gives the song its character and continuity. Furthermore, Schumann is adept in utilizing rhythmic patterns such as dotted rhythms or syncopation, with syncopation in both slow and fast tempos. He also occasionally uses a fast tempo to represent the idea of irony.

Schumann uses a variety of textures throughout Dichterliebe, from chordal accompaniments to small points of imitation between the voice and piano and arpeggiated layers. 
Schumann frequently writes in several layers, and often concentrates on inner voices in the piano. While the melody is highlighted in the top layer, an arpeggiated figure accompanies it, often with a sustained lower melody as well in the bass. Schumann tends to use sustained octaves in the lower register to illustrate a depressive, sorrowful mood. In addition, the layered writing in the piano not only enriches the harmony, but also heightens the experience of listening to the profound collaboration between the voice and piano. Further, the voice and piano are frequently interlaced in alternation and in doubling throughout Dichterliebe. Schumann also makes effective use of silence and varieties of articulation in the piano which enhance the texture.

One of the most common characteristics of both Schumann and Heine in their art is the use of dramatic mood change. Schumann's compositional style in general matches Heine's poetic style. For example, Schumann uses the marking of Lebendig (Lively) in song 15 "Aus alten Märchen winkt es" to create the beautiful dreamland and joyful mood, but switches to Mit innigster Empfindung ("With the most intimate feeling") in the last two verses to reveal the real world. To reflect Heine's mood changes in the poetry, Schumann uses a variety of compositional tools including dynamics, tempo changes, texture changes and surprising harmonies. It is also interesting to note that Schumann uses a different key for each song. In total, he uses seventeen different tonal centers for the entire cycle and does not repeat a tonality.

Moreover, the use of repetition is a distinctive compositional approach of Schumann, which he uses throughout the song cycle in many ways. Schumann often uses a consistent rhythmic pattern throughout an entire song or a large portion of the song. He often creates melodies from a single repeated pitch or bases a phrase on the repetition of a short motive. From the use of repeated chords in the accompaniments and repeated arpeggiated figures to the 
strophic forms, Schumann's use of repetition is one of the most important areas of awareness for the collaboration between the pianist and the singer.

In order to cultivate a foundation of collaboration, understanding the poetry and delving into the musical details are the primary goals for the singer and pianist. Dichterliebe is a perfect example for singers and pianists to develop collaborative skills through analysis because it features easily understandable poetry and miniature structures with clear yet sophisticated musical language. These qualities allow the two performers to concentrate on the details of each distinctive song and also examine the work as a whole. It is hoped that this research provides the singer and pianist with a logical order for building an effective collaboration in each song of Dichterliebe: to understand the poems, literally and emotionally; gain knowledge of compositional techniques including key, structure, and harmony and how Schumann effectively sets Heine's poetry; and gain a deeper understanding of the interaction of the voice and piano. Each song consists of special moments and focusing on the words and the corresponding music is completely indispensable. It is interesting to note that Heine considers his poetry to be "songs," and Schumann takes much literary inspiration in his music. Dichterliebe combines the two art forms in a most unique and complete manner: music and literature, and both art forms are interchangeable. Perhaps in referring to the title of Dichterliebe, the poet is both Heine and Schumann. 


\section{Appendix I: Discography of Schumann's Dichterliebe, op. 48}

The selective sound recordings of renown singer-pianist partnerships are organized chronologically as follows:

Singer's Name

Album Title

Place of Recording

Bernac, Pierre

Dichterliebe: (Poet's love) Op. 48

U.S.A.

Fischer-Dieskau, Dietrich

SCHUBERT, Schwanengesang /

SCHUMANN, Dichterliebe

Salzburger, Austria

Pears, Peter

Britten The Performer

\section{Pianist's Name}

Record Label and Label Number

Date of Recording

Casadesus, Robert

Columbia Masterworks: ML2210

1951

Moore, Gerald

Naxos 8.554219

August 1956

Britten, Benjamin

Decca 4785672 
Fischer-Dieskau, Dietrich

SCHUMANN-Dichterliebe / 12 Kerner-Lieder

Berlin, Germany

Wunderlich, Fritz

Fritz Wunderlich: The 50 Greatest Tracks

München, Germany

Prey, Hermann

Hermann Prey: Essentials

München, Germany

Fischer-Dieskau, Dietrich

Schumann Lieder

Berlin, Germany

Gronroos, Walton

SCHUMANN: Dichterliebe, Op. 48/Liederkreis, Op. 24

Nacka, Sweden
Demus, Jörg

DG E4635052

May 1965

Giesen, Hubert

DG 4796418

November 1965

Hokanson, Lenoard

DG 4837402

1974

Eschenbach, Christoph

DG 4744662

April 1976

Gothóni, Ralf

BIS BIS-CD-92

1977

Brendel, Alfred

Philips 416 352-2

July 1985

Berlin, Germany 
Hynninen, Jorma

SCHUMANN, R.: Dichterliebe /

BRAHMS, J.: 4 Ernste Gesange

Imatra, Finland

Vandersteene, Zeger

SCHUMANN, R.: Dichterliebe op.48 / Liederkreis op.39

Ghent, Belgium

Weir, Scot

Frei aber einsam

Schierstein, Germany

Bluth, Sebastian

SCHUMANN, R.: Dichterliebe, Op. 48 /

Liederkreis, Op. 39

Sandhausen, Germany

Goerne, Matthias

SCHUMANN: Dichterliebe \& Liederkreis op. 24

Winterthur, Switzerland

Bostridge, Ian

SCHUMANN: Liederkries op. 24 /

Dichterliebe op. 48 \& 7 Lieder
Gothoni, Ralf

Ondine ODE7382

October 1985

Kende, Levente

Northern Flowers NF9915

1986

Körber, Till Alexander

Tacet TACET029DIG

1994

Keller, Anita

Orfeo C294921B

November 1996

Ashkenazy, Vladimir

Decca 4582652

April 1997

Drake, Julius

Northern Flowers NF9915 
Egmond, Max van

Schubert \& Schumann: The Romantics, Vol. 3

Roslindale, United States

Güra, Werner

SCHUMANN, R.: Dichterliebe op.48 / Liederkreis op.39

Arles, France

Schreier, Peter

Liederkreis / Dichterliebe

Dresden, Germany

Schmidt, Maximilian

Schumann-Lieder nach Heinrich Heine

Frankfurt, Germany

Padmore, Mark

SCHUMANN: Dichterliebe / Liederkreis op. 24

London, England

Behle, Daniel

SCHUMANN, R.: Dichterliebe / SCHUBERT, F.: Lieder

Berlin, Germany
Slowik, Kenneth

Musica Omnia MO-0102

April 2001

Schultsz, Jan

Harmonia Mundi HMG501766

2002

Schiff, Andras

Orfeo C658051B

July 2002

Huber, Gerold

Oehms Classics OC819

May 2010

Bezuidenhout, Kristian

Harmonia Mundi HMU907521DI

June 2010

Bjelland, Sveinung

Capriccio C5086

June 2010 
Gilchrist, James

SCHUMANN, R.: Liederkreis / Dichterliebe

Monmouthshire, Wales

Lodahl, Peter

Schumann/Christian Jost: Dichterliebe

Berlin, Germany

Hasselhorn, Samuel

DICHTERLIEBE ${ }^{2}$

Hannover, Germany

Prégardien, Julian

SCHUMANN, R.: Dichterliebe

Stuttgart, Germany
Tilbrook, Anna

Linn Records CKD474

March 2014

Heide, Daniel

DG 4837046

October 2017

Kusnezow, Boris

GWK Records GWK141

January, and June 2018

Le Sage, Eric

Alpha ALPHA457

September 2018 


\section{Appendix II: Selected Editions of Schumann's Dichterliebe, op. 48}

Dichterliebe, op. 48. Composed by Robert Schumann. Leipzig, Germany: C.F. Peters, 1844.

Schumann, Clara, ed., Dichterliebe, op. 48, composed by Robert Schumann. Leipzig, Germany: Breitkopf \& Härtel, 1885.

Kagen, Sergius, ed., Dichterliebe, op. 48, composed by Robert Schumann. New York City: International Music Company, 1959.

Ozawa, Kazuko, ed., Dichterliebe, op. 48, composed by Robert Schumann. Munich, Germany: G. Henle Verlag, 2005. 


\section{Bibliography}

Berliner Philharmoniker, "Simon Rattle talks about Brahms and Schumann," September 22, 2014, video, 15:35, https://www.youtube.com/watch?v=yXTTlKdy5q4\&t=16s.

Brody, Elaine, and Robert A. Fowkes. The German Lied and Its Poetry. New York: New York University Press, 1971.

Burtzos, Alex. “'I Could Sing Myself to Death': An Analysis of Schumann's Dichterliebe, Op. 48, X: Hör Ich das Liedchen Klingen.'” Alex Burtzos. https://alexburtzosmusic.com/writing (accessed August 27, 2020).

Craig, David. A Performer Prepares: A Guide to Song Preparation for Actors, Singers and Dances. New York: Applause, 1993.

Daverio, John, and Eric Sams. "Schumann, Robert." Grove Music Online. https://doiorg.wvu.idm.oclc.org/10.1093/gmo/9781561592630.article.40704 (accessed 28 Feb. 2021).

Davidson, Neil H. "Dichterliebe by Robert Schumann.” Master's thesis, North Texas State College, 1957.

François, Fejtö. Heine: A Biography, trans. Mervyn Savill. London: Allan Wingate, 1946.

Glass, Beaumont. Schumann's complete song texts. Genesco, NY: Leyerle Publications, 2002.

Gordon, Stewart. A History of Keyboard Literature: Music for the Piano and Its Forerunners. New York: Schirmer, Cengage Learning, 1996.

Henry Abramson, "Heinrich Heine: Poet of Judenschmerz Jewish Biography as History Dr. Henry Abramson," March 20, 2014, video, 49:31, https://www.youtube.com/watch?v=aMKW8KwoN-U\&t=960s.

Heinrich Heine: Buch der Lieder. "Heine: Ich grolle nicht." https://www.staff.unimainz.de/pommeren/Gedichte/BdL/Lyr-18.html (accessed February 03, 2021). 
Historic Trinity. "Emblems And Icons.” https://www.historictrinity.org/our-

history/architecture/stained-glass/stained-glass-windows-emblems-and-icons/ (accessed December 29, 2020).

Hope College, "Music Department |Presentation on Schumann's "Dichterliebe"," October 8, 2020, video, 50:44, https://www.youtube.com/watch?v=E-LnAmJwikY\&t=829s.

Komar, Arthur, ed., Robert Schumann: Dichterliebe. New York: W·W· Norton \& Company, 1971.

Kimball, Carol. Song: A Guide to Art Song Style and Literature. Milwaukee: Hal Leonard Corporation, 2006.

Layton, Richard Douglas. "Large-Scale Tonal Connections in Robert Schumann's Dichterliebe." Ph.D. diss., University of Maryland, 1991.

Leo, Emilia De. “Im wunderschönen Monat Mai (In the lovely month of May).” Schumannary. https://schumannuary.wordpress.com/?s=im+wundersch (accessed August 20, 2020).

Neumeyer, David. “Organic Structure and the Song Cycle: Another Look at Schumann's Dichterliebe” Music Theory Spectrum, Vol. 4 (1982): 92-105.

Ozawa, Kazuko. Preface to Dichterliebe, Opus 48, by Robert Schumann, edited by Kazuko Ozawa. Munich, Germany: Henle, 2005.

Rosen, Charles. The Romantic Generation. Cambridge, Massachusetts: First Harvard University Press, 1998.

Sams, Eric. The Songs of Robert Schumann. Bloomington and Indianapolis: Indiana University Press, 1993.

Spencer, Hanna. Heinrich Heine. Boston: Twayne Publishers, 1982.

Stein, Deborah and Robert Spillman. Poetry into Song: Performance and Analysis of Lieder. New York: Oxford University Press, 1996.

Swafford, Jan. The Vintage Guide to Classical Music. New York: Vintage Books, 1992.

Taylor, Ronald. Robert Schumann, His Life and Work. New York: Universe Books, 1982.

Whitton, Kenneth S. “The Development of the German Lied.” In Lieder: An Introduction to German Song. 51-56, New York: Franklin Watts, 1984.

Wichael, Scott, "Schumann and the Development of the Collaborative Relationship between Voice and Piano in Opus 48 Dichterliebe.” D.M.A. diss., University of Kansas, 2014.

Young, Percy M. Tragic Muse, The Life and Works of Robert Schumann. London: Dobson, 1961. 